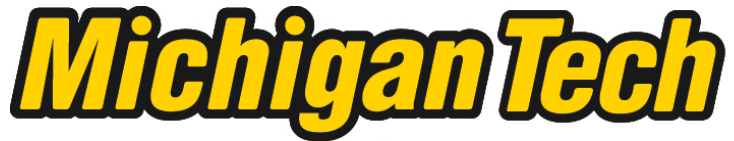 \\ Michigan Technological University Create the Future Digital Commons @ Michigan Tech
}

Dissertations, Master's Theses and Master's Reports - Open

Dissertations, Master's Theses and Master's

Reports

2004

\section{Hydrogeochemical controls on uranium in aquifers of the Jacobsville Sandstone}

Heidi M. Sherman

Michigan Technological University

Follow this and additional works at: https://digitalcommons.mtu.edu/etds

Part of the Geology Commons

Copyright 2004 Heidi M. Sherman

\section{Recommended Citation}

Sherman, Heidi M., "Hydrogeochemical controls on uranium in aquifers of the Jacobsville Sandstone", Dissertation, Michigan Technological University, 2004.

https://doi.org/10.37099/mtu.dc.etds/337

Follow this and additional works at: https://digitalcommons.mtu.edu/etds

Part of the Geology Commons 


\title{
HYDROGEOCHEMICAL CONTROLS ON URANIUM IN AQUIFERS OF THE JACOBSVILLE SANDSTONE
}

\author{
by \\ HEIDI M. SHERMAN
}

\begin{abstract}
A DISSERTATION
Submitted in partial fulfillment of the requirements

for the degree of

DOCTOR OF PHILOSOPY

(Geology)

MICHIGAN TECHNOLOGICAL UNIVERSITY 2004
\end{abstract}


This dissertation, "Hydrogeochemical Controls on Uranium in Aquifers of the Jacobsville Sandstone," is hereby approved in partial fulfillment of the requirements for the degree of DOCTOR OF PHILOSOPHY in the field of Geology.

\title{
DEPARTMENT:
}

Geological \& Mining Engineering \& Sciences

\author{
Signatures: \\ Dissertation Advisor: Dr. John S. Gierke \\ Department Chair: Dr. Wayne D. Pennington
}

August 9, 2004 
Michigan Technological University

Abstract

\title{
HYDROGEOCHEMICAL CONTROLS ON URANIUM IN AQUIFERS OF THE JACOBSVILLE SANDSTONE
}

\author{
by Heidi M. Sherman \\ Department of Geological \& Mining Engineering \& Sciences
}

The occurrence of elevated uranium $(U)$ in sandstone aquifers was investigated in the Upper Peninsula of Michigan, focusing on aquifers of the Jacobsville Sandstone. The hydrogeochemical controls on groundwater $U$ concentrations were characterized using a combination of water sampling and spectral gamma-ray logging of sandstone cliffs and residential water wells. ${ }^{235} \mathrm{U} /{ }^{238} \mathrm{U}$ isotope ratios were consistent with naturally occurring $\mathrm{U}$. Approximately $25 \%$ of the 270 wells tested had U concentrations above the U.S. Environmental Protection Agency Maximum Contaminant Level (MCL) of $30 \mu \mathrm{g} / \mathrm{L}$, with elevated $U$ generally occurring in localized clusters. Water wells were logged to determine whether groundwater $U$ anomalies could be explained by the heterogeneous distribution of $\mathrm{U}$ in the sandstone. Not all wells with relative $\mathrm{U}$ enrichment in the sandstone produced water with $\mathrm{U}$ above the MCL, indicating that the effect of $U$ enrichment in the sandstone may be modified by other hydrogeochemical factors. Well water had high redox, indicating $\mathrm{U}$ is in its highly soluble (VI) valence. Equilibrium modeling indicated that aqueous $\mathrm{U}$ is complexed with carbonates. In general, wells with elevated U concentrations had low ${ }^{234} \mathrm{U} /{ }^{238} \mathrm{U}$ activity ratios. However, in some areas $\mathrm{U}$ concentrations and ${ }^{234} \mathrm{U} /{ }^{238} \mathrm{U}$ activity ratios were simultaneously high, possibly indicating differences in rock-water interactions. Limited groundwater age dating suggested that residence time may also help explain variations in well water $U$ concentrations. Low levels of $U$ enrichment (4 to $30 \mathrm{ppm}$ ) in the Jacobsville sandstone may make wells in its oxidized aquifers at risk for $U$ concentrations above the MCL. On average, $\mathrm{U}$ concentrations were highest in heavy mineral and clay layers and rip up conglomerates. Uranium concentrations above $4 \mathrm{ppm}$ also occurred in siltstones, sandstones and conglomerates. Uranium enrichment was likely controlled by deposition processes, sorption to clays, and groundwater flow, which was controlled by permeability variations in the sandstone. Low levels of $U$ enrichment were found at deltaic, lacustrine and alluvial fan deposits and were not isolated to specific depositional environments. 


\section{PREFACE}

The following document has been formatted as an Electronic Thesis or Dissertation (ETD). Hyperlinks are intended to facilitate navigation from the table of contents, to figures and tables referenced in the text, to other locations within the main document, as well as to supplementary supporting files. After following a hyperlink, the reader may use the back button on the tool bar to return to the previous location in the document. The linked figures and tables are located at the end of the text document and are numbered sequentially. 


\section{ACKNOWLEDGEMENTS}

This research was funded in part by Michigan Technological University, the U.S.

Department of Education Graduate Assistance in Areas of National Need (GAANN) Program, the Michigan Space Grant Consortium (MSGC) and the DeVlieg Foundation.

I would like to thank the well owners who provided water samples and gave their permission to conduct geophysical surveys on their property. This study would not have possible without their cooperation.

I wish to acknowledge Dr. Albert "Buddy" Wylie for his assistance locating and interpreting the Amoco core and accompanying spectral gamma-ray log, Dr. Doug McDowell for XRD analysis of core and outcrop samples and Elizabeth Siedlecki for help making thin sections.

A special thank you goes to my husband, Anthony Crook, for his patience and support, as well as countless hours of invaluable technical and field assistance. I would also like to thank my mom and brother for their support and assistance with fieldwork.

My greatest appreciation goes to my academic advisor, Dr. John Gierke, who took me in as his graduate student and offered me the guidance and encouragement needed to complete this dissertation. 


\section{TABLE OF CONTENTS}

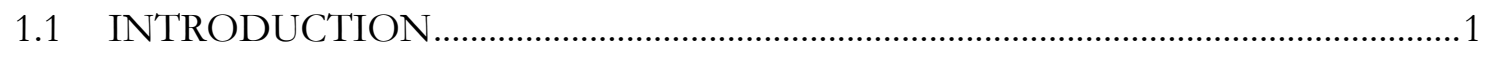

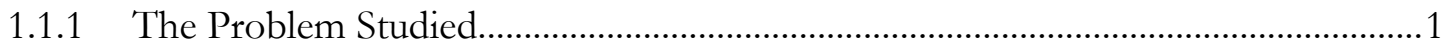

1.1.2 Health Implications of Uranium in Drinking Water ..................................................

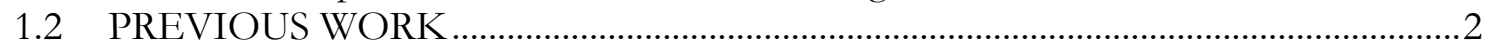

1.2.1 Studies Investigating Elevated Uranium in Aquifers................................................

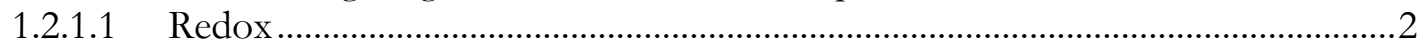

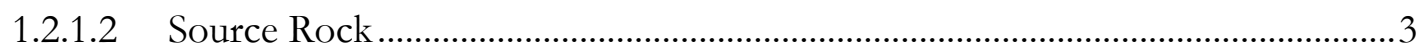

1.2.1.3 Residence Time ...................................................................................... 5

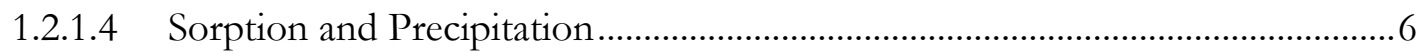

1.2.2 Studies Investigating ${ }^{234} \mathrm{U} /{ }^{238} \mathrm{U}$ Activity Ratios.......................................................

1.2.2.1 Variation in ${ }^{234} \mathrm{U} /{ }^{238} \mathrm{U}$ Activity Ratios ................................................................

1.2.2.2 Inverse Relationship Between ${ }^{234} \mathrm{U} /{ }^{238} \mathrm{U}$ Activity Ratios and U......................... 7

1.2.2.3 High ${ }^{234} \mathrm{U} /{ }^{238} \mathrm{U}$ Activity Ratios at U Occurrences ............................................... 7

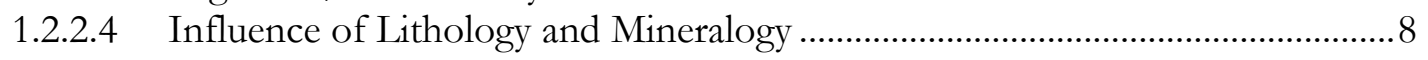

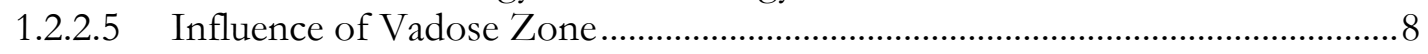

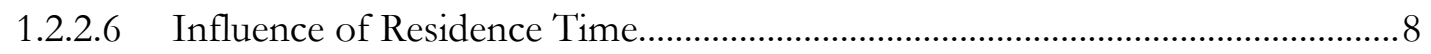

1.2.2.7 Elucidating Groundwater Mixing and Flow Patterns.......................................... 8

1.2.2. $\quad{ }^{234} \mathrm{U} /{ }^{238} \mathrm{U}$ Activity Ratio of Host Rock ................................................................... 9

1.2.2. $\quad{ }^{234} \mathrm{U} /{ }^{238} \mathrm{U}$ Activity Ratio Summary ................................................................. 9

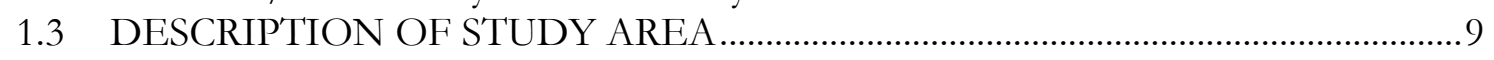

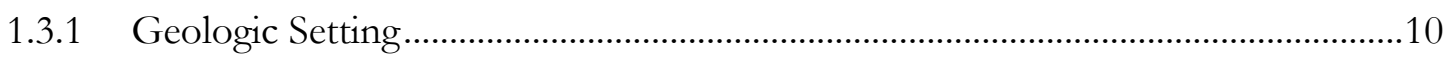

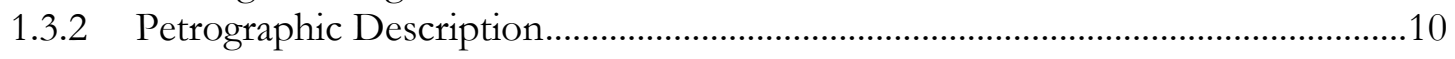

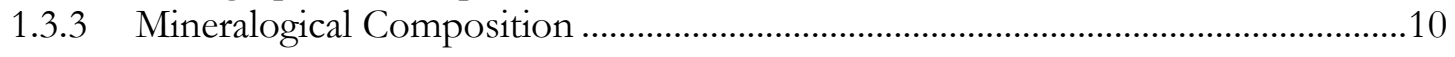

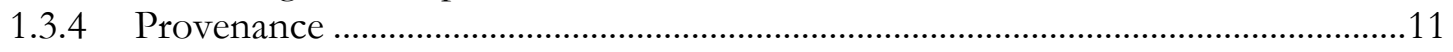

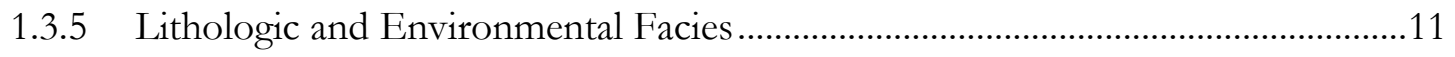

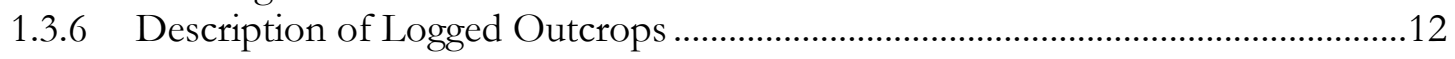

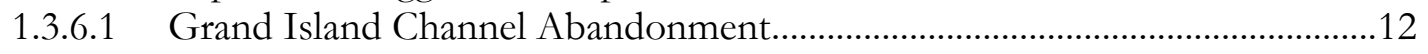

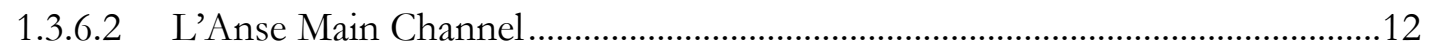

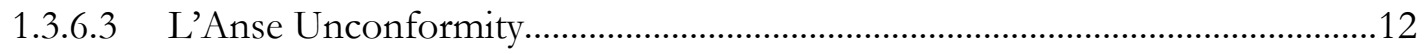

1.3.6.4 Keweenaw Bay Deltaic Channel........................................................................... 13

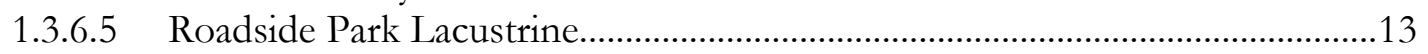

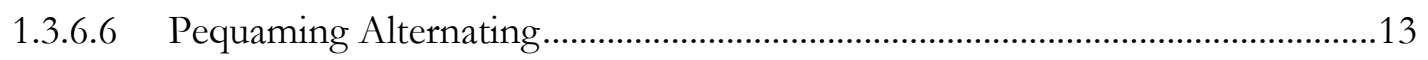

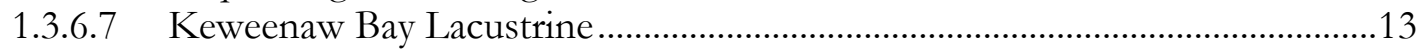

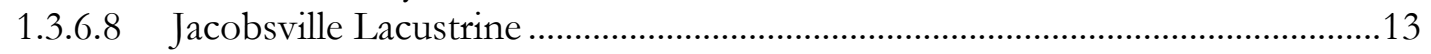

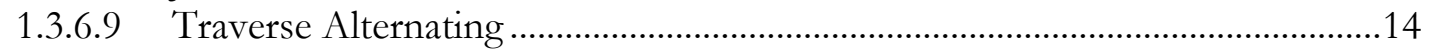

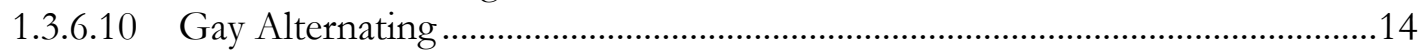

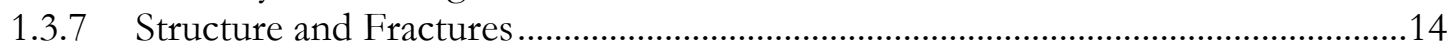

1.3.8 Uranium Exploration in Michigan's Upper Peninsula ..............................................14

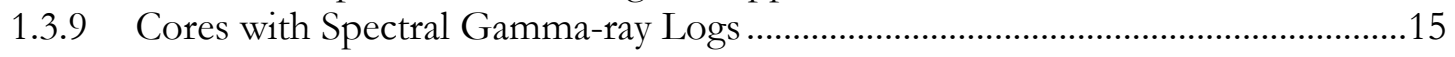

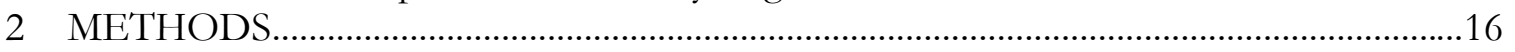

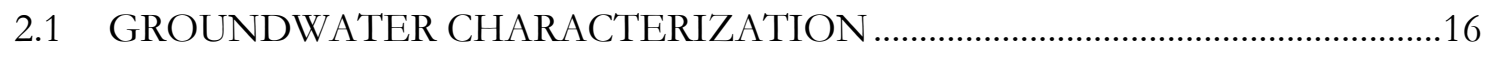

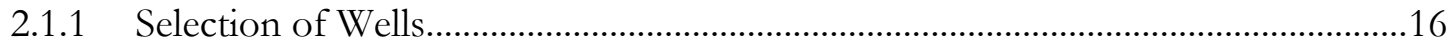

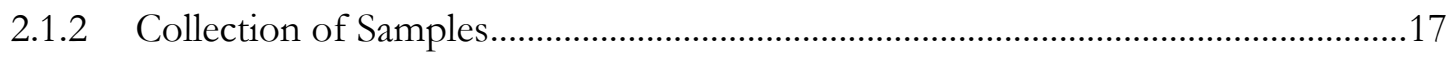

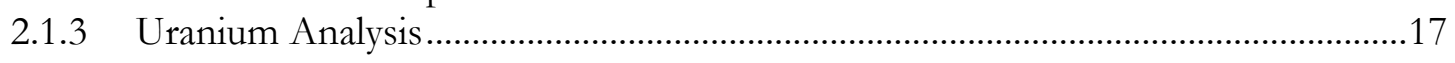

2.1.4 Redox and Geochemical Analysis .....................................................................18 


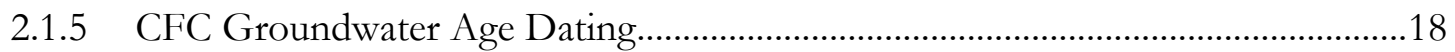

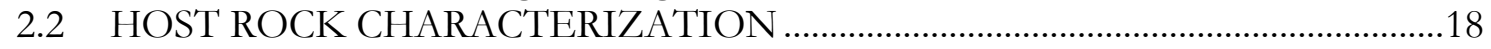

2.2.1 Gamma Ray Spectrometry of Wells and Outcrops ...............................................18

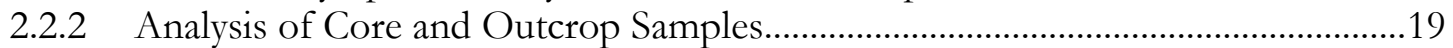

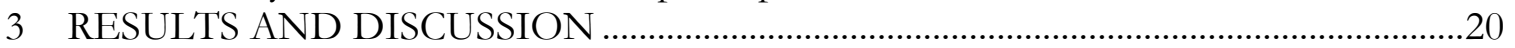

3.1 RESULTS FROM GROUNDWATER CHARACTERIZATION ............................20

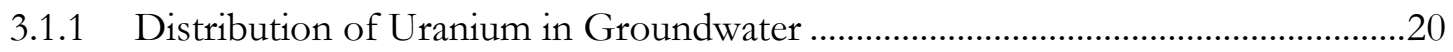

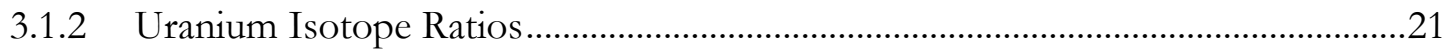

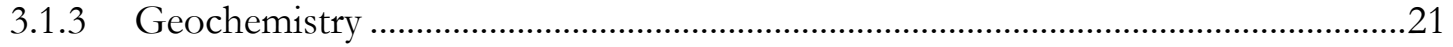

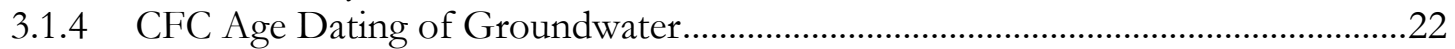

3.2 RESULTS FROM HOST ROCK CHARACTERIZATION .......................................22

3.2.1 Lateral Continuity of Uranium in the Jacobsville Sandstone ....................................22

3.2.2 Comparison of Uranium Concentration in Well Water and Host Rock ................23

3.2.3 Distribution of Uranium in Jacobsville Sandstone Outcrops ..................................24

3.2.4 Distribution of Potassium and Thorium in the Jacobsville Sandstone...................24

3.2.5 Interpretation of Uranium Occurrences Using Ratio Curves ..................................26

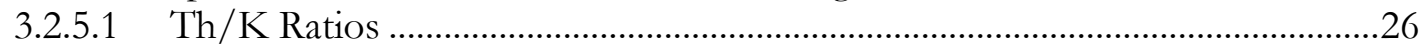

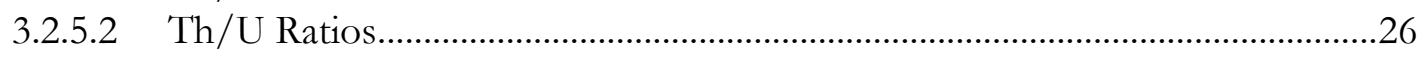

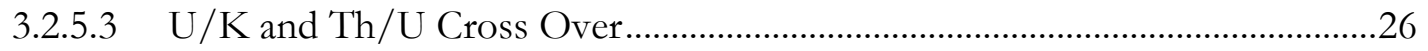

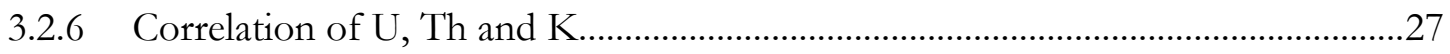

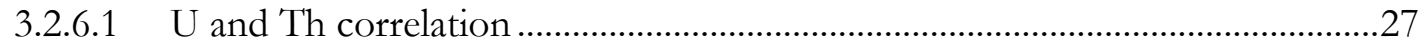

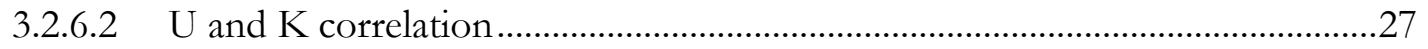

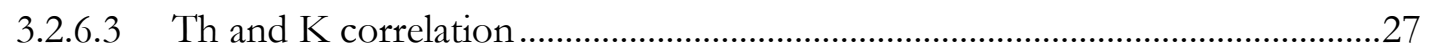

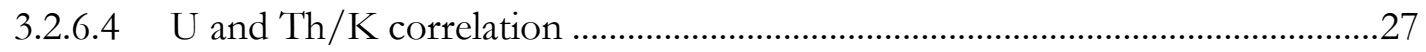

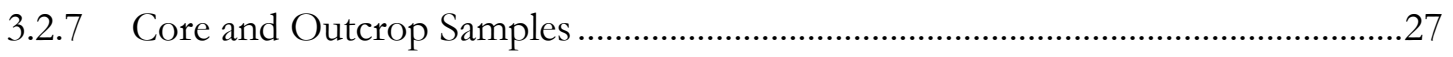

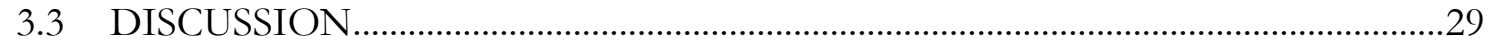

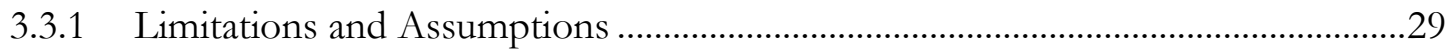

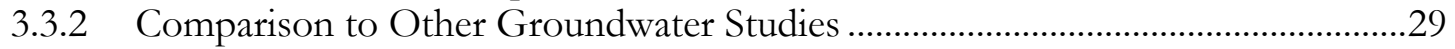

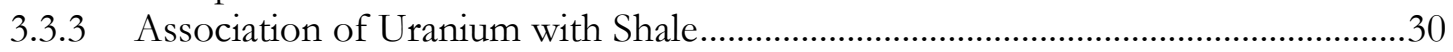

3.3.4 Secondary Uranium Minerals more Soluble than Primary Uranium Minerals .....31

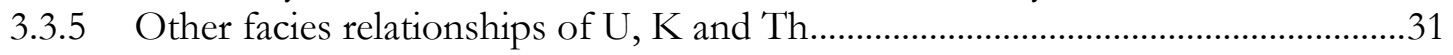

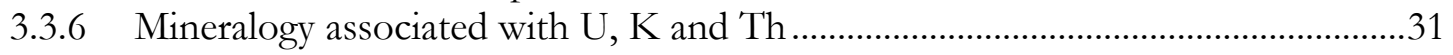

4 CONCLUSIONS AND RECOMMENDATIONS FOR FUTURE WORK …..............32

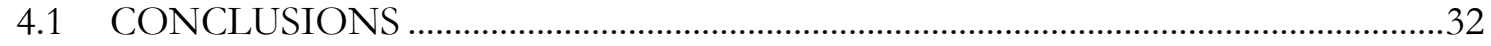

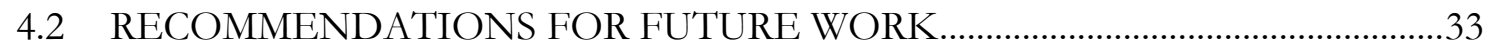

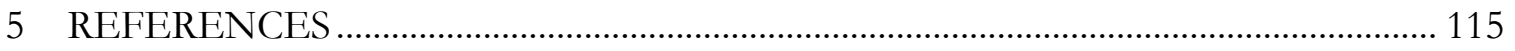




\section{LIST OF FIGURES}

Figure 1 Distribution of $U$ in well water in relation to bedrock geology...................................35

Figure 2 Location of outcrops logged with a gamma-ray spectrometer. ….................................36

Figure 3 Location of wells logged with a gamma-ray spectrometer. ............................................3

Figure 4 Stratigraphic column of relevant formation in the study area.......................................3

Figure 5 Distribution of $U$ in well water in relation to topography..........................................39

Figure 6 Distribution of $U$ in well water in relation to Quaternary geology..............................40

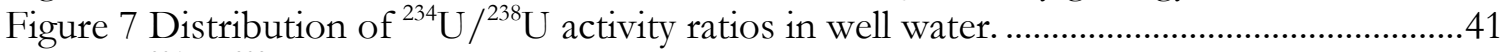

Figure $8{ }^{234} \mathrm{U} /{ }^{238} \mathrm{U}$ activity ratio versus reciprocal of $\mathrm{U}$ concentration.......................................42

Figure $9{ }^{234} \mathrm{U} /{ }^{238} \mathrm{U}$ activity ratio versus reciprocal of $\mathrm{U}$ : Houghton-Chassell area.....................43

Figure $10{ }^{234} \mathrm{U} /{ }^{238} \mathrm{U}$ activity ratio versus reciprocal of $\mathrm{U}$ : select moderate to high $\mathrm{U}$ wells.....44

Figure $11 \mathrm{U}$, Th and $\mathrm{K}$ curves for the Grand Island Channel Abandonment outcrop...........45

Figure $12 \mathrm{U}$, Th and $\mathrm{K}$ ratio curves for the Grand Island Channel Abandonment outcrop 46

Figure $13 \mathrm{U}$, Th and K curves for the L'Anse Main Channel outcrop......................................47

Figure $14 \mathrm{U}$, Th and $\mathrm{K}$ ratio curves for the L'Anse Main Channel outcrop..............................48

Figure $15 \mathrm{U}$, Th and $\mathrm{K}$ curves for the L'Anse Unconformity outcrop......................................49

Figure $16 \mathrm{U}$, Th and $\mathrm{K}$ ratio curves for the L'Anse unconformity outcrop...............................50

Figure $17 \mathrm{U}$ and at the Keweenaw Bay Deltaic Channel outcrop. ............................................51

Figure $18 \mathrm{U}$, Th and K curves for the Roadside Park Lacustrine outcrop................................52

Figure $19 \mathrm{U}$, Th and $\mathrm{K}$ ratio curves for the Roadside Park Lacustrine outcrop.......................53

Figure $20 \mathrm{U}$, Th and $\mathrm{K}$ curves for the Pequaming Alternating outcrop....................................54

Figure $21 \mathrm{U}$, Th and $\mathrm{K}$ ratio curves for the Pequaming Alternating outcrop ..........................55

Figure $22 \mathrm{U}$, Th and $\mathrm{K}$ curves for the Keweenaw Bay Lacustrine outcrop. ..............................56

Figure $23 \mathrm{U}$, Th and $\mathrm{K}$ ratio curves for the Keweenaw Bay Lacustrine outcrop......................57

Figure $24 \mathrm{U}$, Th and $\mathrm{K}$ curves for the Jacobsville Lacustrine outcrop. ......................................58

Figure $25 \mathrm{U}$, Th and $\mathrm{K}$ ratio curves for the Jacobsville Lacustrine outcrop.............................59

Figure $26 \mathrm{U}$, Th and $\mathrm{K}$ curves for the Traverse Alternating outcrop. .......................................60

Figure $27 \mathrm{U}$, Th and $\mathrm{K}$ ratio curves for the Traverse Alternating outcrop ...............................61

Figure $28 \mathrm{U}$, Th and $\mathrm{K}$ curves for the Gay Alternating outcrop ................................................62

Figure $29 \mathrm{U}$, Th and K ratio curves for the Gay Alternating outcrop. ....................................63

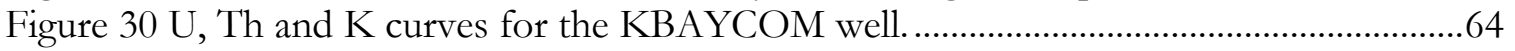

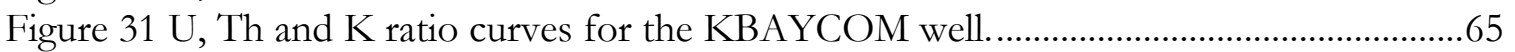

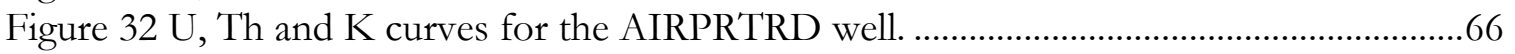

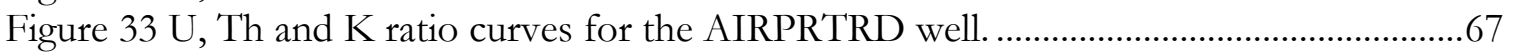

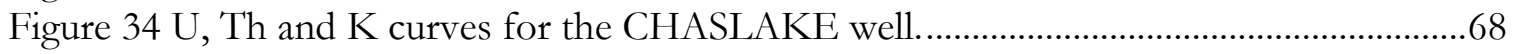

Figure $35 \mathrm{U}$, Th and $\mathrm{K}$ ratio curves for the CHASLAKE well.................................................69

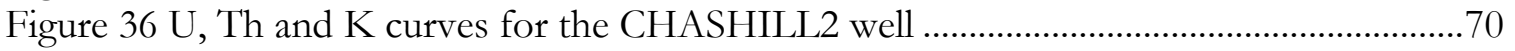

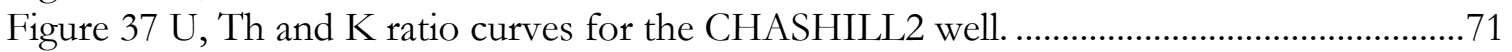

Figure $38 \mathrm{U}$, Th and K curves for the CHASHILL3 well ..........................................................72

Figure $39 \mathrm{U}$, Th and $\mathrm{K}$ ratio curves for the CHASHILL3 well. ................................................73

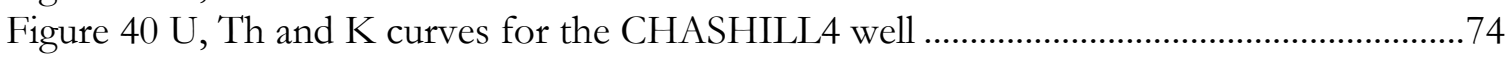

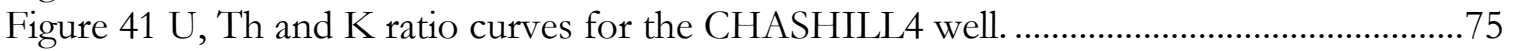

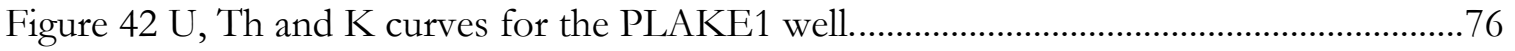

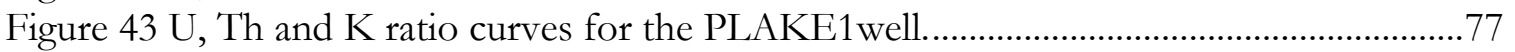

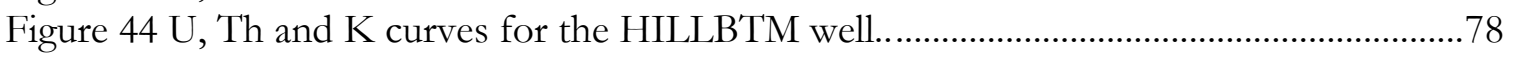

Figure $45 \mathrm{U}$, Th and $\mathrm{K}$ ratio curves for the HILLBTM well.......................................................79 


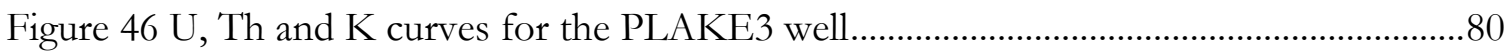

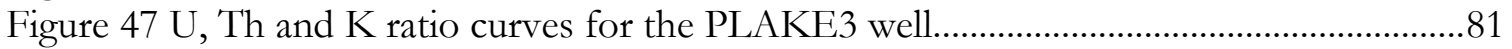

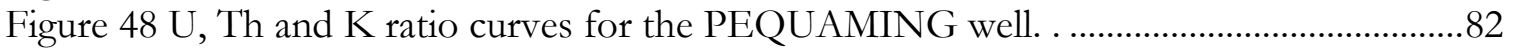

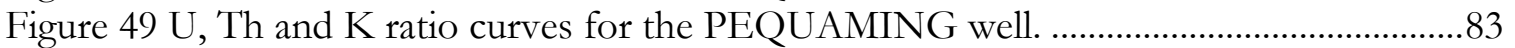

Figure $50 \mathrm{U}$, Th and $\mathrm{K}$ curves for the HILLTOP well. .............................................................. 84

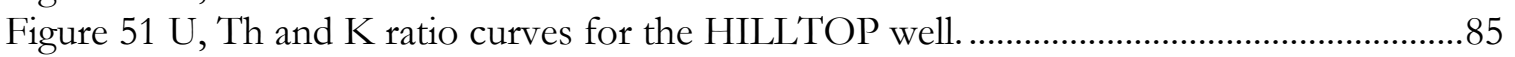

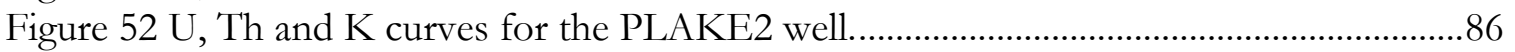

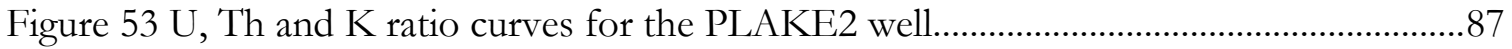

Figure $54 \mathrm{Well} \operatorname{logs}(\mathrm{eU})$ positioned in relation to mean sea level............................................8

Figure 55 Spectral gamma-ray data from outcrop grouped by grain size.................................89

Figure $56 \mathrm{Th} / \mathrm{K}$ plot for the CHASHILL2 well............................................................................ 90

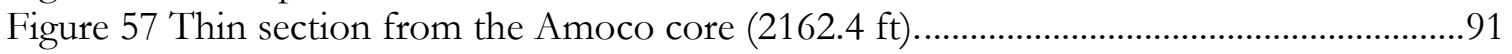




\section{LIST OF TABLES}

Table 1 Comparison of Gross Alpha and U Analysis...........................................................92

Table 2 Comparison of NURE and U Analysis from this Study.............................................93

Table 3 Comparisons of Multiple Analyses....................................................................................94

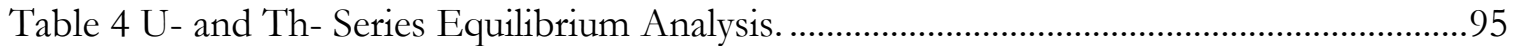

Table 5 Uranium Species and Saturation Indices for a Well with Elevated U..........................96

Table 6 Uranium Species and Saturation Indices for a Well with Low U.............................. 102

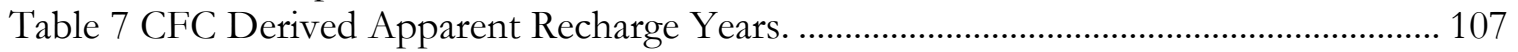

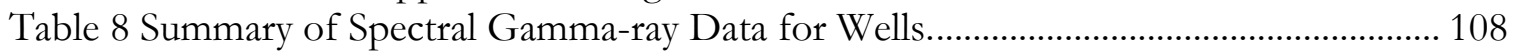

Table 9 Summary of Spectral Gamma-ray Data for Outcrops................................................... 110

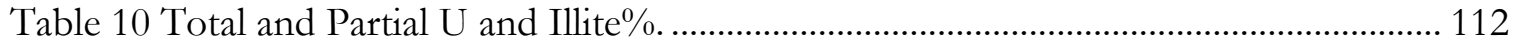

Table 11 Analyses of Samples From Rice Lake Core............................................................... 113 


\section{LIST OF SUPPLEMENTARY FILES}

Digitized Amoco log
U analysis from LITER
Logging data (Excel)
Flow cell data
ArcView Project [no link available]
Expanded view of study area
Photos of outcrops
Photos of fieldwork
Photos of core
Photos of thin sections
Notes on thin sections
Notes on Amoco log
Methods from MI DEQ
Correlation of well logs
AR Charts
Th/K Charts

Digitized Amoco log

CoreLog.las

liter.pdf

LogData.xls

FlowCell.pdf

arcviewu (directory)

Layout.pdf

OutcropP.pdf

FieldPic.pdf

AmocoPic.pdf

ThinPics.pdf

ThinNote.pdf

LogNotes.pdf

800CMS.pdf

sealevel.pdf

AR.pdf

ThKPlots.pdf
(490 KB)

(415 KB)

$(459 \mathrm{~KB})$

(750 KB)

(124 MB)

(1.43 MB)

(49.24 MB)

(97.56 MB)

(48.72 MB)

(4.02 MB)

(45 KB)

(11.32 MB)

(533 KB)

(298 KB)

(244 KB)

(1.74 MB) 


\section{INTRODUCTION AND OVERVIEW}

\section{$1.1 \quad$ INTRODUCTION}

\subsubsection{The Problem Studied}

Uranium $(\mathrm{U})$ is a naturally occurring radioactive element and heavy metal in groundwater. In December 2003, the U.S. Environmental Protection Agency (EPA) began regulating U in community water supplies in order to reduce the risk of cancer and kidney disease. The EPA estimates that approximately 500 community water systems (1\%) will be affected by the new $30 \mu \mathrm{g} / \mathrm{L}$ (ppb) maximum contaminant level (MCL) (EPA 2000). Other regulatory agencies that have recommended limits on $\mathrm{U}$ in drinking water include: the World Health Organization $(2 \mu \mathrm{g} / \mathrm{L})$, Health Canada $(20 \mu \mathrm{g} / \mathrm{L})$, Australian Drinking Water Guidelines (20 $\mu \mathrm{g} / \mathrm{L})$, and Bavarian water authorities (5 $\mu \mathrm{g} / \mathrm{L})$ (Kinze 2002).

Uranium is highly soluble in shallow oxidized groundwater (Ingebritsen 1998). Granite and gneiss aquifers tend to have low $\mathrm{U}$ concentrations in the water even though the host rocks may contain primary U-bearing minerals. Sandstones typically have lower U concentrations than granites but may produce high groundwater U concentrations (Merkel et al. 2002) if the $\mathrm{U}$ phase is relatively soluble. Understanding the controls on groundwater $\mathrm{U}$ concentrations might help to avoid areas with the potential for elevated $U$ or allow for managing the well system in a manner that lessens the need for removing elevated $U$ concentrations to facilitate compliance with the new $\mathrm{U}$ regulation.

Motivated by community concern over elevated radioactivity in well water, the author planned and conducted an investigation into the hydrogeochemical controls on the naturally occurring $\mathrm{U}$ isotope distribution in aquifers of the Jacobsville Sandstone located in Michigan's Upper Peninsula. The objectives of this study were to:

- Determine the extent and distribution of elevated $U$ in aquifers of the Jacobsville Sandstone.

- Explain spatial variations in groundwater $U$ in relation to redox, groundwater chemistry, groundwater residence time, the heterogeneous distribution of $U$ in the host rock and $U$ phase.

- Utilize ${ }^{234} \mathrm{U} /{ }^{238} \mathrm{U}$ activity ratios to differentiate the mechanisms responsible for elevated $\mathrm{U}$ concentrations in groundwater.

- Investigate $\mathrm{U}$ concentrations in the Jacobsville Sandstone in relation to lithologic and depositional facies.

- Characterize U occurrences in the Jacobsville Sandstone.

These objectives were pursued through a combination of $U$ analysis of water samples from 271 wells, detailed chemical analysis of selected wells, spectral gamma-ray logging of 10 outcrops and 12 wells (with U concentrations above and below the MCL), core analysis and chlorofluorocarbon (CFC) age dating of wells along a flow path.

\subsubsection{Health Implications of Uranium in Drinking Water}

This study was motivated largely by the new MCL, which was established by the EPA to reduce health risks from consuming drinking water with elevated $U$ concentrations. 
However, this study focused on the hydrogeochemical controls on $U$ in groundwater and did not investigate whether elevated $U$ concentrations in aquifers of the Jacobsville Sandstone were linked to occurrences of kidney disease or cancer. Nevertheless, some observations from previous studies and anecdotal results from this study may be of interest to the reader.

Two cancer deaths occurred among well owners participating in the study, both with elevated $U$ in their water. However, it is not clear that $U$ was a contributing factor. It is difficult to determine a statistical relationship between potential cancer clusters and well water U concentrations, especially in areas with low population density. Seiler (2004) investigated water quality at a childhood leukemia cluster near Fallon, Nevada and found that $U$ concentrations in wells used by case families did not differ significantly from the remainder of the domestic wells sampled.

In addition, because the $\mathrm{U}$ MCL is considered to be conservative, well owners with $\mathrm{U}$ concentrations slightly above $30 \mathrm{ppb}$ are not likely to exhibit health affects. For example, Hakonson-Hayes et al. (2002) studied natural U in well water in New Mexico, which contained up to $1200 \mathrm{ppb} \mathrm{U}$, and determined a corresponding kidney $\mathrm{U}$ concentration of 0.8 ppm, which did not exceed the $1 \mathrm{ppm}$ threshold for kidney toxicity. Perhaps an easier relationship to investigate would be the connection between elevated $U$ in well water and elevated $U$ accumulated in the body, such as in the hair, where it is easily sampled. Although several well owners in this study area with elevated $U$ in their well water apparently had elevated $\mathrm{U}$ in their hair, results were only available for one person. According to the laboratory (Doctors Data, Chicago), his hair had a concentration of $0.2 \mathrm{ppm} \mathrm{U}$, which was one standard deviation above the mean. The individual estimated his hair $\mathrm{U}$ concentration might be 20 times the mean. The corresponding well water $U$ concentration was $73 \mathrm{ppb}$, which is about 37 times the mean groundwater concentration. Well owners with $U$ above the MCL who installed reverse osmosis systems successfully reduced their well water $\mathrm{U}$ concentrations below the MCL.

\subsection{PREVIOUS WORK}

\subsubsection{Studies Investigating Elevated Uranium in Aquifers}

Previous studies have examined hydrogeochemical controls on groundwater $\mathrm{U}$ concentrations including redox conditions, host-rock $U$ concentration, groundwater residence time and sorption. Summaries of this work are provided below in decreasing order of importance, based on the literature, for elevated uranium in groundwater. More details about the previous work and how it pertains to results from this study are described in the discussion sections below.

\subsubsection{Redox}

It is well established in the geochemical literature that under reducing conditions, $\mathrm{U}$ is in its tetravalent (IV) state and should be present in stable mineral form. For example, the solubility limit of uraninite $\left(\mathrm{UO}_{2},\right)$ suggests that the maximum groundwater $\mathrm{U}$ concentration would be about $0.06 \mathrm{ppb}$ (Gascoyne 1992). High redox, however, causes U-bearing minerals to be more soluble. Uranium is about 10,000 times more soluble in its oxidized hexavalent (VI) state (Ingebritsen 1998). Areas with high redox and elevated U concentrations in the rock are at risk for high U concentrations in groundwater (Kinze 2002). Ayotte et al. (2002) 
found high $\mathrm{U}$ associated with high dissolved oxygen and low dissolved iron in New England groundwater. Szabo and Zapecza (1991) showed that high U in the Newark Basin, New Jersey, was associated with high dissolved oxygen. While not all groundwater $U$ studies determined redox conditions, the presence of elevated $U$ in groundwater is a strong indicator of high redox.

\subsubsection{Source Rock}

Stable $\mathrm{U}$ deposits under reducing groundwater conditions result in low U solubility. However, dispersing $U$ accumulations and oxidized groundwater near stable deposits may result in elevated groundwater $U$ concentrations. Numerous studies on elevated $U$ in aquifers identified the host rocks as formations hosting known $\mathrm{U}$ deposits or previously identified U mineralization. For example:

- Nikie et al. (2002) studied U in groundwater in Triassic sediments in Servia and Bulgaria, including a varicolored sandstone, which contained U occurrences. High groundwater $\mathrm{U}$ concentrations (ranging from 0.1 to $40.9 \mathrm{ppb}$ ) were considered a consequence of uraniferous horizons formed in Lower Triassic sediments.

- Sinha et al. (1997) studied U concentration in groundwater in India. The geology of the area was sedimentary rocks and U-enriched granite of Proterozoic age with ore grade up to $37,000 \mathrm{ppm}$. Of 412 wells tested, the average groundwater U was $13 \mathrm{ppb}$. Several areas of high groundwater U (217-4,500 ppb in 13 villages) were identified.

- Lee et al. (2001) investigated the Okchun Metamorphic Belt in Korea, which is covered with low U-bearing black shales (average U $250 \mathrm{ppm}$ ), and frequently produces groundwater $U$ concentrations greater than $50 \mathrm{ppb}$.

- Verstraeten et al. (2002) studied U in groundwater in an alluvial valley in Nebraska and concluded that groundwater $\mathrm{U}$ concentrations above $10 \mathrm{ppb}$ were likely due to dissolution of volcanic ash and uraniferous sediments. Uranium concentrations up to $31.1 \mathrm{ppb}$ were found in river water where streams drained marine sediments containing $\mathrm{U}$.

- Parker and Herbert (2002) reported that Texas ranked third in domestic production of $U$ by exploitation of sandstone roll-front deposits via open pit mines, which led to groundwater contamination. Lee and Herbert (2001) compiled data from the National Uranium Resource Evaluation (NURE) program in a GIS database and utilized geology, soil survey, land use and vegetation base maps to investigate trace metals in groundwater resources in Texas.

Elevated $\mathrm{U}$ in groundwater has been reported in aquifers, however, without significant $\mathrm{U}$ mineralization in the host rock, e.g., Kim (1999) investigated U in Paleozoic aquifers in the Llano Uplift area of central Texas where U concentrations in 128 sandstone and shale samples averaged only $3.8 \mathrm{ppm}$ and ranged from 1 to $8.5 \mathrm{ppm}$. They concluded that U was most likely to be found in groundwater flowing through intervals of high concentrations of shaly laminae, phosphatic material, or Fe-oxide cements. More frequently, studies in regions without previously identified $\mathrm{U}$ mineralization did not measure rock $\mathrm{U}$ concentrations. 
Previous studies were frequently qualitative in their association of elevated $U$ in groundwater with potentially U-rich formations. Even quantitative studies did not investigate a correlation between rock U concentrations and specific wells with elevated U. Szabo (1997) used borehole geophysical logging to identify strata with elevated radioactivity to characterize the distribution of dissolved radionuclides in the Newark Basin, New Jersey. However, Szabo (1997) did not specifically log wells with elevated groundwater U concentrations.

Studies have shown that the $\mathrm{U}$ phase in the rock may be as important as the bulk $\mathrm{U}$ concentrations, particularly in crystalline rocks, where $U$ mineralization in fractures may increase groundwater $U$ concentrations, such as:

- Hollacher and Yuskaitis (1993) found U concentrations up to $495 \mathrm{ppb}$ in bedrock wells of the Conway Granite, which has $U$ mineralization in microcracks and relatively high $\mathrm{U}$ solubility compared to other rocks. However, most wells had $<1$ ppb and a small fraction had $>10 \mathrm{ppb}$.

- Temple (2002) investigated elevated U in groundwater (up to $3000 \mathrm{ppb}$ ) center around Simpsonville, South Carolina. Temple hypothesized that high U concentrations were due to U-rich fractures in the granitic rocks. Only relatively deep wells contained high $U$ concentrations, possibly because $U$ had already been leached from shallow fractures.

- Kim and Becker (2001) studied elevated radionuclide occurrences in Northwest Vermont well water. They showed that the Cambro-Ordovician dolomites had primary and secondary U occurrences. Detrital zircon, apatite, monazite and sphene were found disseminated throughout, and secondary sphalerite, galena, and pyrite were associated with fractures. Fluid migration along major fault zones was thought to concentrate radionuclides in some bedrock wells.

Elevated $\mathrm{U}$ in groundwater has been reported in aquifers around the world in a variety of geologic environments, including felsic igneous and volcanic rocks, metamorphic rocks, and clastic sedimentary rocks. Basalt aquifers have consistently low $\mathrm{U}$ concentrations.

- Zouridakis et al. (2002) found groundwater U concentrations in the Migdonia basin, Greece varied from 0 to $48.9 \mathrm{ppb}$ (most were lower than $7 \mathrm{ppb}$ ). Granitic bodies with elevated concentrations of natural radioelements, including $\mathrm{U}$, exist around the basin.

- Albertson (2003) investigated U in groundwater of the Piedmont and Blue Ridge physiographic provinces. About $30 \%$ of 628 samples were greater than $30 \mathrm{ppb}$ and seven counties had at least one sample greater than $300 \mathrm{ppb}$.

- Porcelli (2001) investigated U-series nuclides in the Baltic Shield watershed. In general, groundwaters from bedrock aquifers were found to have much higher $\mathrm{U}$ concentrations and ${ }^{234} \mathrm{U} /{ }^{238} \mathrm{U}$ activity ratios than groundwaters from glacial till 
deposits. Areas with extensive peat, however, may first concentrate and subsequently discharge aqueous $\mathrm{U}$.

- Asikainen (1980) studied radioactivity in wells in Finland and determined a national average of $19.8 \mathrm{ppb}$; the highest reading was 4,600 ppb. The geology of areas with high $\mathrm{U}$ is primarily granite, amphibolite, hornblende gneiss and quartz-feldspar schists.

- Seiler (2004) studied water quality near Fallon, Nevada and found that $18 \%$ of 100 wells exceeded the U MCL and three samples exceeded $100 \mathrm{ppb}$. Almost all of the samples having $\mathrm{U}>\mathrm{MCL}$ were from the shallow basin-fill aquifers. None of the samples from the basalt aquifer had U>MCL.

- Betcher et al. (1988) studied U in groundwater of southeastern Manitoba, Canada. Of 287 wells tested, the mean was $58.3 \mathrm{ppb}$ and the maximum value was $2020 \mathrm{ppb}$. Uranium concentrations were highest in samples from Precambrian rock aquifers (115.6 ppb). Uranium concentrations up to $250 \mathrm{ppb}$ were found in or associated with Lake Agassiz clay deposits.

- Norvell 1995 studied $U$ in the central Oklahoma aquifer and found up to 318 ppb U in deep wells (more than $300 \mathrm{ft}$ deep) and $220 \mathrm{ppb} \mathrm{U}$ in shallow wells. Aquifer features controlling the distribution of high $\mathrm{U}$ concentrations included the distribution of mudstone and sandstone and the distribution of U-bearing minerals.

These studies illustrate the global extent of elevated $U$ in aquifers and the need for a quantitative understanding of how host-rock $U$ concentrations affect groundwater $U$ concentrations, particularly in formations that do not contain known U deposits, such as the Jacobsville Sandstone. There is also a need to investigate the relationship between the heterogeneous distribution of $U$ in the host rock and the spatial distribution of $U$ in groundwater as well as characterizing the type of $U$ occurrence, all of which are addressed in this study.

\subsubsection{Residence Time}

Mathematical models indicate an increasing trend, sometimes linear (e.g., Tricca 2000), in groundwater $\mathrm{U}$ concentrations with groundwater age. Given sufficient residence time and favorable geochemistry, elevated U may occur in groundwater even without U-rich rocks (Szabo and Zapecza 1991). The residence time required to produce elevated groundwater U concentrations depends on the U phase in the rock. Durance (1984) studied the New Red Sandstone in southeast Devon and found that sedimentary rock sequences with primary, detrital, U-bearing minerals required long residence times to increase the $U$ content of young groundwater to appreciable levels. Even though the rock concentration of $U$ was as high as $4 \mathrm{ppm}$, the relatively young (i.e., less than 50 year old) groundwater had less than $1 \mathrm{ppb} \mathrm{U}$. Conversely, rocks with secondary $\mathrm{U}$ may rapidly result in groundwater $\mathrm{U}$ concentrations up to $30 \mathrm{ppb}$. However, unless the groundwater can be successfully dated, or secondary minerals observed, it is not yet possible to resolve the interaction of time and availability. In other geologic settings $U$ concentrations may decrease with residence time, e.g., Brasser et al. (2002) studied U migration in argillaceous sediments in Heselbach Site, Germany and 
concluded that $\mathrm{U}$ concentrations in groundwater decreased with flow direction due to Uretention by sorption processes.

While groundwater $U$ concentrations may change along a flow path, they are usually static at a given location, e.g., Seiler (2004) resampled 29 wells that were tested in 1989 and found that groundwater $\mathrm{U}$ concentrations in the wells stayed the same over time.

\subsubsection{Sorption and Precipitation}

While $\mathrm{U}$ is highly soluble in oxidized groundwater and may achieve concentrations in the parts per million, groundwater samples tend to be undersaturated with respect to common $\mathrm{U}$ minerals (e.g., Ivanovich et al. (1991)). Groundwater U concentrations are further controlled by sorption and precipitation processes, e.g., $\mathrm{U}$ can be incorporated into hematite structure (Duff et al. 2002) or adsorbed on colloidal magnetite (Missana et al. 2003). Sato et al. (1997) found high $\mathrm{U}$ concentrations $(8 \mathrm{wt} \%)$ in iron nodules down gradient of the $\mathrm{U}$ ore deposit at Koongarra, Australia. Apparently, U was initially adsorbed and then fixed by precipitation of copper uranyl phosphate microcrystals, which resulted in retardation of U over long time scales. Arnold et al. (1998) studied U sorption onto muscovite, quartz, chlorite and albite feldspar in a phyllite. They found that sorption was higher for the whole rock $(97 \%)$ than for the individual minerals measured. They suggested that iron had been leached from chlorite during the batch experiment and formed ferrihydrite, which has a huge specific surface area and was likely responsibly for adsorbing the majority of $\mathrm{U}$ in solution.

However, negatively charged $U$ carbonate complexes prevail at high carbonate concentrations and limit $U$ sorption on the negatively charged mineral surfaces (Abdelouas et al. 1998). Coprecipitation of $U$ with aragonite and calcite may occur at laboratory temperatures. Duff and Amrhein (1996) studied U(VI) sorption on goethite and soil and found maximum adsorption occurred in solutions with low carbonate alkalinities $(<3$ $\mathrm{mmol} / \mathrm{L})$, ionic strength and $\mathrm{Ca}$ and $\mathrm{P}$ concentrations. $\mathrm{U}(\mathrm{VI})$ carbonates, e.g., $\mathrm{UO}_{2}\left(\mathrm{CO}_{3}\right)_{2}{ }^{2-}$ and $\mathrm{UO}_{2}\left(\mathrm{CO}_{3}\right)_{3}{ }^{4-}$, are highly soluble and negatively charged and resulted in lesser to negligible adsorption of $\mathrm{U}$ to soil surfaces.

During sorption, $\mathrm{U}(\mathrm{VI})$ tends to remain in its soluble hexavalent $(\mathrm{VI})$ valence. When sorption is reversed U(VI) is released back into groundwater. Reduction of U(VI) to U(IV) is the preferred mechanism of $U$ removal in contaminated areas (Fiedor et al. 1998). Fore example, Abdelouas et al. (2003) showed that U(VI) can be reduced to U(IV) and precipitated as a uraninite solid by denitrifying and Fe(III)-reducing bacteria.

\subsubsection{Studies Investigating ${ }^{234} \mathrm{U} /{ }^{238} \mathrm{U}$ Activity Ratios}

Osmond and Cowart (1992) summarized U disequilibria in groundwater based on activity ratios. Where ${ }^{234} \mathrm{U} /{ }^{238} \mathrm{U}$ activity ratios (AR) are near 1 (i.e., secular equilibrium) in the host rock, simple weathering will result in groundwater ${ }^{234} \mathrm{U} /{ }^{238} \mathrm{U}$ activity ratios in equilibrium. Elevated ${ }^{234} \mathrm{U} /{ }^{238} \mathrm{U}$ activity ratios in groundwater occur, in part, due to alpha recoil (Osmond and Cowart 1992). When ${ }^{238} \mathrm{U}$ decays by alpha decay to ${ }^{234} \mathrm{Th}$, the Th nucleus may be recoiled out of the mineral into the groundwater. The ${ }^{234} \mathrm{Th}$ decays via ${ }^{234} \mathrm{~Pa}$ to ${ }^{234} \mathrm{U}$, resulting in an excess of ${ }^{234} \mathrm{U}$ in the groundwater. Porcelli \& Swartzenski (2003) theorized that some

${ }^{234} \mathrm{U}$ atoms are oxidized during alpha decay due to stripping of electrons or an increase in positive charge during the two beta decays via tetravalent ${ }^{234} \mathrm{Th}$ and pentavalent ${ }^{234} \mathrm{~Pa}$. In 
addition, since ${ }^{234} \mathrm{U}$ is resident in damaged lattice locations, it is more vulnerable to oxidation by fluids and ${ }^{234} \mathrm{Th}$ may push oxygen atoms in front of it leading to oxidation. Oxidation results in ${ }^{234} \mathrm{U}(\mathrm{VI})$ being more soluble than ${ }^{238} \mathrm{U}(\mathrm{IV})$.

\subsubsection{Variation in ${ }^{234} U{ }^{238} U$ Activity Ratios}

${ }^{234} \mathrm{U} /{ }^{238} \mathrm{U}$ activity ratios are generally between 1 and 2 , though they have been measured from 0.5 to 12 (Gascoyne 1981) and up to 27.88 in the fluvial-lacustrine Guarany aquifer in South America (Bonotto et al. 2000). The specific activity for ${ }^{234} \mathrm{U}(6,252.813 \mathrm{pCi} / \mu \mathrm{g})$ is much higher than for ${ }^{238} \mathrm{U}(0.336 \mathrm{pCi} / \mu \mathrm{g})$. Therefore, the variation in ${ }^{234} \mathrm{U} /{ }^{238} \mathrm{U}$ activity ratios complicates the conversion of $\mathrm{U}$ activity in groundwater to mass concentration. For example, Wong et al. (1999) showed that a conversion of $0.79 \mathrm{pCi} / \mu \mathrm{g}$ was more appropriate for California than the national average $1.3 \mathrm{pCi} / \mu \mathrm{g}$ established by the EPA.

\subsubsection{Inverse Relationship Between ${ }^{234} U /{ }^{238} U$ Activity Ratios and $U$ Concentration}

Uranium isotope studies frequently show an inverse relationship between ${ }^{234} \mathrm{U} /{ }^{238} \mathrm{U}$ activity ratio and U concentration in groundwater. Asikainen (1980) studied U in well water in Finland and found that high activity ratios occurred with highest frequency at low $U$ concentrations $(\mathrm{U}<10 \mathrm{ppb})$ and highest frequency at high concentration (U>100 ppb). Cowart and Osmond (1980) studied 300 groundwater samples from eight known U deposits in Texas and in Wyoming and observed low ${ }^{234} \mathrm{U} /{ }^{238} \mathrm{U}$ activity ratios where the accumulations were being dispersed and depleted by groundwater. Similarly, Lee et al. (2001) interpreted ${ }^{234} \mathrm{U} /{ }^{238} \mathrm{U}$ activity ratios close to equilibrium in a hot springs area as a result of rapid erosion of the rock strata by the hot spring water. Hot mineral springs with low $\mathrm{U}$ concentrations may be more likely to have high ${ }^{234} \mathrm{U} /{ }^{238} \mathrm{U}$ activity ratios (Hakam et al. 2001). High ${ }^{234} U /{ }^{238} U$ activity ratios are often associated with low $U$ concentrations where $U$ solubility is limited by low redox and precipitation of $U$ on the aquifer grains facilitated alpha recoil. However, oxygen-rich, U-poor groundwater of a dolomitic aquifer in South Africa was also found to have variable to high ${ }^{234} \mathrm{U} /{ }^{238} \mathrm{U}$ activity ratios (Kronfeld et al. 1994), requiring a different mechanism for excess ${ }^{234} \mathrm{U}$.

In contrast, Abdul-Hadi et al. (2001) studied U isotopes in Syrian groundwater (U: 0 - 6.13 ppb; AR: 0.52 - 2.02) and reported that ${ }^{234} \mathrm{U} /{ }^{238} \mathrm{U}$ activity increased with $\mathrm{U}$ concentrations. Other studies have determined that there is not a clear linear relationship between ${ }^{234} \mathrm{U} /{ }^{238} \mathrm{U}$ activity ratios and $\mathrm{U}$ concentration (e.g., Luo 2000).

\subsubsection{High ${ }^{234} U{ }^{238} U$ Activity Ratios at $U$ Occurrences}

High ${ }^{234} \mathrm{U} /{ }^{238} \mathrm{U}$ activity ratios in groundwater frequently occur at stable $\mathrm{U}$ deposits.

Groundwater down-dip from $U$ accumulations often exhibits low $U$ concentrations and high activity ratios (Cowart and Osmond 1980). Ivanovich (1991) showed that ${ }^{234} \mathrm{U} /{ }^{238} \mathrm{U}$ activity ratios increase asymptotically along flow paths in shallow oxidized aquifers and jump to high values at redox fronts, where low $U$ solubility results in precipitation of $U$ on the aquifer grains. This precipitation, in turn, enhances alpha-recoil-derived ${ }^{234} \mathrm{U}$. In deep aquifers, ${ }^{234} \mathrm{U} /{ }^{238} \mathrm{U}$ activity ratios decrease with time and depth (decaying regime). Noseck et al. (2002) investigated Tertiary basins in a western part of the Czech Republic, where clay and organic material accumulate $U$ and the found rather high (2-5) groundwater ${ }^{234} \mathrm{U} /{ }^{238} \mathrm{U}$ activity ratios in the areas of major $\mathrm{U}$ enrichment. Tricca (2000) showed that high ${ }^{234} \mathrm{U} /{ }^{238} \mathrm{U}$ activity ratios could also be achieved through low weathering rates. 


\subsubsection{Influence of Lithology and Mineralogy}

The ${ }^{234} \mathrm{U} /{ }^{238} \mathrm{U}$ activity ratios may also be influenced by lithology. Roback et al. (2001) investigated U isotopes at the Snake River Plain aquifer in Idaho (U: 0.3- 3.6 ppb; AR 1.53.1) and found higher ${ }^{234} \mathrm{U} /{ }^{238} \mathrm{U}$ activity ratios occurred in recharge areas where old, damaged clastic material was thought to enhance leaching and alpha recoil. The ${ }^{234} \mathrm{U} /{ }^{238} \mathrm{U}$ activity ratios decreased along flow pathways toward secular equilibrium in the basalt aquifer. Porcelli and Swartzenski (2003) explained that changes in U host phase or geochemistry influence weathering without influencing recoil, which results in a change in the ${ }^{234} \mathrm{U} /{ }^{238} \mathrm{U}$ activity ratio.

\subsubsection{Influence of Vadose Zone}

Tricca et al. (2001) studied U-series nuclides in a sandy unconfined aquifer on Long Island and concluded that weathering in the vadose zone resulted in elevated $\mathrm{U}$ and ${ }^{234} \mathrm{U} /{ }^{238} \mathrm{U}$ activity ratios. Variations in ${ }^{234} \mathrm{U} /{ }^{238} \mathrm{U}$ activity ratios in the vadose zone were preserved in the aquifer. Tricca (2000) showed that groundwater with both high $U$ concentrations and high ${ }^{234} \mathrm{U} /{ }^{238} \mathrm{U}$ activity ratios may indicate an influence of the vadose zone or low weathering rates combined with long flow distances or low water velocities. Reynolds et al. (2002) studied a sandy confined aquifer in northwest New Mexico and found high ${ }^{234} \mathrm{U} /{ }^{238} \mathrm{U}$ activity ratios (approximately 9, combined with low U concentrations), which were attributed to low weathering rates. However, because the vadose zone had high $\mathrm{U}$ and low ${ }^{234} \mathrm{U} /{ }^{238} \mathrm{U}$ activity ratios, the authors speculated that the paleoclimate in the region might have been cooler and wetter 5000 years ago, which would have resulted in lower $U$ concentrations in the vadose zone water.

\subsubsection{Influence of Residence Time}

Ivanovich and Alexander (1987) hypothesized that ${ }^{234} \mathrm{U} /{ }^{238} \mathrm{U}$ activity ratios near secular equilibrium might indicate very young ( $<30 \mathrm{yr}$ old) or very old ( $>2 \mathrm{Myr}$ old) water. Young, oxidizing recharge water undersaturated with $U$ would leach $U$ from the host rock, resulting in activity ratios near unity. Very old groundwater in a closed system would decay to secular equilibrium. Ivanovich et al. (1991) showed that ${ }^{234} \mathrm{U} /{ }^{238} \mathrm{U}$ activity ratios gradually increase asymptotically with time in shallow oxidized aquifers and then rapidly decrease at the redox front. Tricca (2000) calculated that ${ }^{234} \mathrm{U} /{ }^{238} \mathrm{U}$ activity ratios should increase with distance and reach an asymptotic value over large distances. As may be expected, not all studies follow this pattern, e.g., Reynolds et al. (2002) and found high ${ }^{234} \mathrm{U} /{ }^{238} \mathrm{U}$ activity ratios (lowest was about 6 ) but did not observe a regular increase with age.

\subsubsection{Elucidating Groundwater Mixing and Flow Patterns}

Understanding $\mathrm{U}$ isotope ratios has broad ramifications because of their potential for tracing groundwater from different aquifer conditions (Porcelli and Swarzenski 2003). Osmond and Cowart (1992) developed plots of ${ }^{234} \mathrm{U} /{ }^{238} \mathrm{U}$ activity ratios versus the reciprocal of $\mathrm{U}$ concentration and interpreted straight-line arrays as evidence of mixing or dilution of different groundwater. Ivanovich and Alexander (1987) showed that U isotopes could be used to identify groundwater masses and evaluate mixing for a sedimentary sequence in the Harwell region of the United Kingdom. However, factors besides mixing influence ${ }^{234} \mathrm{U} /{ }^{238} \mathrm{U}$ activity ratios. Cuttell et al. (1988) studied U-series isotopes in the Permo-Triassic sandstone aquifer in the U.K. and concluded that $U$ concentrations and ratios were not simply controlled by mixing of saline, relatively high $\mathrm{U}$ (but less than $<30 \mathrm{ppb}$ ) waters with 
freshwaters with lower $\mathrm{U}$. Other possible factors were isotopic content of the matrix, the matrix mineralogy and fabric, the redox conditions, the salinity, and carbonate chemistry. Chabaux et al. (2000) studied U flux from Himalayan Rivers and observed that these rivers had characteristic ${ }^{234} \mathrm{U} /{ }^{238} \mathrm{U}$ activity ratios for each structural Himalayan unit. Paces et al. (2002) used distinctive $\mathrm{U}$ concentrations and ${ }^{234} \mathrm{U} /{ }^{238} \mathrm{U}$ activity ratios to determine groundwater regimes around Yucca Mountain, Nevada.

\subsubsection{8 ${ }^{234} U /{ }^{38} U$ Activity Ratio of Host Rock}

Factors that result in excess ${ }^{234} \mathrm{U}$ in groundwater simultaneously deplete ${ }^{234} \mathrm{U}$ in the host rock, especially along preferential groundwater flow paths. This relationship has been used to distinguish between groundwater flow regimes. Cuttell et al. (1988) conducted bulk rock analyses for a Permo-Triassic sandstone and concluded that ${ }^{234} \mathrm{U}$ was depleted relative to

${ }^{238} \mathrm{U}$, except for a lower permeability unit, indicating preferential loss of ${ }^{234} \mathrm{U}$ to groundwater and flushing of freshwater (disequilibria was not as great in the groundwater as in the rock). Gascoyne et al. (2002) studied U-series disequilibrium in tuffs from Yucca Mountain, Nevada and found that excess ${ }^{234} \mathrm{U}$ had been removed from the rock $\left({ }^{234} \mathrm{U} /{ }^{238} \mathrm{U}\right.$ activity ratio of 0.95 ) during the past 350 thousand years, probably by pore fluids. Fractured and unfractured rocks showed the same ${ }^{234} \mathrm{U}$ deficiency, which was interpreted as evidence that pore fluids moved equally through fractured and unfractured rock. Israelson et al. (1997) determined that organic-rich lake sediments in southern Scandinavia showed age-dependent variations in ${ }^{234} \mathrm{U} /{ }^{238} \mathrm{U}$ activity ratios: 0.958 (9426 $\mathrm{yr} \mathrm{BP}$ ) and 0.919 (3058 $\left.\mathrm{yr} \mathrm{BP}\right)$. Soil in the catchment area had a ${ }^{234} \mathrm{U} /{ }^{238} \mathrm{U}$ activity ratio of 0.587 . Latham and Schwarcz (1987) studied U-series disequilibria of mineral separates from the Eye-Dashwa lakes granite (Canada) and found ${ }^{234} \mathrm{U} /{ }^{238} \mathrm{U}$ activity ratios less than 1 for most of the ferromagnesian, quartz, feldspar, zircon and sphene grains. Dissolution of rock with ${ }^{234} \mathrm{U} /{ }^{238} \mathrm{U}$ activity ratios less than 1 moderates ${ }^{234} \mathrm{U} /{ }^{238} \mathrm{U}$ activity ratios in groundwater.

\subsubsection{9 ${ }^{234} U /{ }^{38} U$ Activity Ratio Summary}

Determining ${ }^{234} \mathrm{U} /{ }^{238} \mathrm{U}$ activity ratios is necessary for conversion between activity and mass concentrations for compliance monitoring. Additionally, understanding the spatial and temporal distribution of ${ }^{234} \mathrm{U} /{ }^{238} \mathrm{U}$ activity ratios has broader implications for finger printing groundwater, determining mixing trends, and identifying flow patterns in rock. Strong dissolution of $U$ minerals leads to high groundwater $U$ concentrations and low ${ }^{234} U /{ }^{238} \mathrm{U}$ activity ratios. The classic redox front model explains low groundwater $U$ concentrations in conjunction with high ${ }^{234} \mathrm{U} /{ }^{238} \mathrm{U}$ activity ratios. Low weathering rates may result in low groundwater $\mathrm{U}$ concentrations and high ${ }^{234} \mathrm{U} /{ }^{238} \mathrm{U}$ activity ratios. Long groundwater residence time, or influence from the vadose zone, may result in simultaneously high groundwater $\mathrm{U}$ concentrations and high ${ }^{234} \mathrm{U} /{ }^{238} \mathrm{U}$ activity ratios, however these conditions are less well understood and require further investigation

\subsection{DESCRIPTION OF STUDY AREA}

The immediate proximity of the Jacobsville Sandstone to Michigan Technological University facilitated the investigation of elevated $U$ in Jacobsville Sandstone aquifers. Abundant outcrops in the form of sandstone cliffs along Lake Superior were useful for characterizing $\mathrm{U}$ occurrences in terms of lithologic and depositional facies. Further, because this research was motivated by health concerns of $U$ in drinking water, rather than exploration for mineral 
deposits, residential well owners and land owners were generally eager to participate in the study.

\subsubsection{Geologic Setting}

The Jacobsville Sandstone was deposited as basin fill in the 1.1 Ga Midcontinent Rift System within the North American craton. The 2000-km long rift system has been characterized by outcrop and core description and geophysical surveys and was recently summarized by Ojakangas et al. (2001). Subsidence and the development of a system of half grabens along the rift allowed the accumulation of $20 \mathrm{~km}$ of volcanic rocks and $10 \mathrm{~km}$ of post-rift clastic sediments along the rift and in flanking basins. Initial red beds were composed of volcanic material from within the basin. Later predominantly fluvial red beds, such as the Jacobsville Sandstone, had sources outside the basin. Rifting along the midcontinent was terminated due to the continental collision of the Grenville Orogeny. A stratigraphic column shows the vertical relationship between formations in the study area.

Bedrock controls topography in the area and is overlain by Quaternary deposits including: lacustrine sand and gravel, lacustrine clay and silt, and coarse and fine textured glacial till.

\subsubsection{Petrographic Description}

Hedgeman (1992) described the Jacobsville Sandstone east of Lake Gogebic, from Lake Gogebic to Marquette, Michigan, as a relatively flat lying, moderately to well-sorted, medium- to fine-grained sandstone, containing only local basal conglomerates. However, as discussed below, non-basal conglomerates were described in this study. Hamblin (1956) provided an early comprehensive description of the texture, color and composition of the Jacobsville Sandstone. The Jacobsville Sandstone varies from shale to conglomerate and is red and reddish-brown with white streaks, blotches and spots. The red color is a primary feature and the subsequent leaching by reducing fluids occurred along the relatively permeable, massive, coarse-grained layers. As a result, the relatively coarse sandstone units tend to be white or pink, while the shales and fine-grained layers are red. Color changes are generally associated with bedding planes and may follow cross bedding.

\subsubsection{Mineralogical Composition}

Hamblin (1956) described the composition of the Jacobsville Sandstone as $75 \%$ rounded to subangular quartz grains. Most of the quartz grains were derived from an igneous source (straight extinction), 15\% showed undulatory extinction and some were polycrystalline indicating metamorphic origin. Feldspar typically constituted less than $15 \%$ of grains, primarily as microcline, as well as orthoclase and plagioclase. Other grains include pyroxene, amphibole, and fragments of basalt and iron formation $(<8 \%)$. Cements include sericite, illite, iron oxide and calcium carbonate.

The heavy minerals in the Jacobsville Sandstone may be important for characterizing $U$ and Th occurrences. According to Hamblin (1956), 50 to 80\% of heavy minerals in the Jacobsville Sandstone are opaque. The most abundant species are magnetite, hematite and ilmenite. Garnet, tourmaline, leucoxene and zircon are usually present. Anatase, apatite, augite, biotite, collophane, epidote and staurolite constitute less than $5 \%$ of the heavy minerals. The heavy mineral assemblage is relatively constant throughout the Jacobsville Sandstone and minor differences were attributed to differences in the lithology of the 
provenance. Hedgeman (1992) described the heavy mineral suite as mature, including ilmenite, magnetite, zircon, tourmaline and rutile. One sample had minor amounts of monazite and amphiboles. Samples collected east of Lake Gogebic had well-rounded heavy minerals. Lindsay (1986) described the heavy minerals as comprising 3.2\% of the Jacobsville Sandstone with hematite and magnetite the most abundant.

\subsubsection{Provenance}

The Jacobsville Sandstone had a U-rich (Johnson 1977) and primarily southern provenance, including iron formation, quartzite, metasiltstone, vein quartz, and chert conglomerate clasts and plutonic and metamorphic sand sized grains. Only undeformed sandstone, siltstone and silicic volcanic rock fragments (all minor) had a northern provenance (Hedgeman 1992). The Precambrian highlands in Michigan represent the provenance of the Jacobsville Sandstone (Hamblin 1956).

\subsubsection{Lithologic and Environmental Facies}

This study investigated whether there was a correlation between rock $U$ concentrations and specific facies of the Jacobsville Sandstone. Hamblin (1956) described four lithologic facies in the Jacobsville Sandstone: conglomerate, lenticular sandstone, massive sandstone and siltstone. Hamblin (1956) further interpreted the depositional environment of outcrops as alluvial, deltaic and lacustrine. The conglomerate facies consists of well-developed channelfill structures, which include large angular blocks of soft shale that were deposited in a fluvial environment.

The lenticular sandstone facies is the dominant facies and contains features associated with channels and fluvial deposition, including trough cross stratification, clay pebbles, mud cracks, and ripple marks.

The massive sandstone facies consists of relatively persistent bedding that average 5 -feet thick. Most of the massive beds have horizontal or cross-stratification, particularly near the base, while others are structureless. Symmetrical oscillation ripples can be traced for hundreds of feet and have an average ripple wavelength of 2.5 inches and amplitude of 0.5 inches. At Keweenaw Bay, ripples at different horizons have the similar amplitude and length, indicating a constant water depth/energy relationship. These features suggest a change from fluvial to lacustrine depositional environment, which likely existed intermittently.

The red siltstone facies is associated with the massive sandstone facies and may represent alternating fluvial and lacustrine deposition.

Babcock (1975) further subdivided facies in the Jacobsville Sandstone from oldest to youngest and proximal to distal as: conglomerate (A), cross-bedded (B1), flat-bedded (B2), and cross-laminated (B3) sandstones, alternating beds (C), and siltstones (D).

Based on ripple data, Babcock (1975) used Tanner's equation to calculate a shallow (1 m) paleo water depth, supported by the existence of mud-cracked ripple marks. Fluvial sands, representing alluvial fans, were thought to have existed northwest and southeast of the paleolake. Lindsay (1986) also described the Jacobsville Sandstone as a fluvial and lacustrine 
formation. Daniels and Elmore (1988) described the Jacobsville Sandstone as comprised of various fluvial/deltaic/lacustrine facies. Hedgeman (1992) disagreed, claiming that there were no known deltaic or lacustrine facies; all the conglomerates and sandstones were fluvial and there was no evidence of standing water of any kind. Similarly, Bowers (1989) interpreted the sandstones in the Rice Lake core (Houghton County, Center Sec. 14, T. 55, R 32) as flash-flood deposits and the rippled siltstone as evidence of overbank or waning flood deposits.

\subsubsection{Description of Logged Outcrops}

Ten Jacobsville Sandstone outcrops were logged with a spectral gamma-ray probe to determine whether rock $\mathrm{U}$ concentrations were related to lithologic and depositional facies. Outcrops were selected based on depositional and lithologic facies, proximity to wells in the study, cooperation of landowners, accessibility and availability of trees to use for anchoring ropes. The number of outcrops surveyed in this study was limited by time and financial constraints. The outcrop headings below are linked to later figures (Figures $11-29)$ that include photographs of the outcrops. Additional photographs of these and other outcrops are provided in the supplementary files. Outcrops referred to below as alternating consist of white sandstones with interbedded, red, silty sandstones, likely representing channel and overbank deposits. Outcrops referred to as lacustrine consist of laterally continuous beds of fine-grained sandstone. Channel outcrops contain trough cross-bedded structures.

\subsubsection{Grand Island Channel Abandonment}

This 12-m long by 4-m high Jacobsville Sandstone outcrop is located on the west side of Grand Island. A horizontal profile was logged across the fluvial, trough cross-bedded channel structure and the clayey ( $81 \%$ illite) material, which is interpreted as an abandonment feature, on the side of the channel. This outcrop is accessible by kayak.

\subsubsection{L'Anse Main Channel}

A 19-m vertical profile was logged at L'Anse Red Rocks, at the US 41 road cut at the southern end of Keweenaw Bay. This outcrop consists of a large channel structure containing sand and gravel representing a fluvial environment. Sandstones are (B1) crossbedded (Babcock 1975), corresponding to Hamblin's lenticular sandstone and conglomerate. This is a thick section (12 $\mathrm{m}+/$-) of mainly flat lying, arkosic, medium-grained, variably bleached sandstones showing cross- and disturbed bedding. At least four thin pebble horizons are exposed in the cliff. Authigenic biotite and muscovite occur on bedding plane partings and kaolinite occurs as cement (Babcock 1975). The sediment transport direction is $\mathrm{N} 60^{\circ} \pm 15^{\circ} \mathrm{W}$ (Hamblin 1958).

\subsubsection{L'Anse Unconformity}

The large channel structure described above lies unconformably on the Michigamme slates. A short $(3 \mathrm{~m})$ vertical profile was logged across the unconformity. As described by Babcock (1975), a conglomerate of variable thickness $(0.1$ to $1.1 \mathrm{~m})$ lies just above the basal contact. The maximum clast size is large cobble $(17 \mathrm{~cm})$. The provenance for most of the rock types present was less than $25 \mathrm{~km}$ to the south and east. Pebble types in order of decreasing abundance, are vein quartz, quartzite, iron-formation and chert, Michigamme Slate, phyllite, and argillite and hornblendic schist. The variety of pebble types reflects the large variety of Precambrian rocks exposed in that area (Hamblin 1956). 


\subsubsection{Keweenaw Bay Deltaic Channel}

This 5-m long by 1-m high leached channel feature is located on the west side of Keweenaw Bay near the Keweenaw Bay Community, 0.5 miles south of the cliff at the roadside park. Babcock (1975) described this outcrop as C facies alternating beds (sandstones and siltstones) deposited in a deltaic-lacustrine environment. The leached fluvial-deltaic orthoquartzitic (FDOQ) sands are interbeds in the red to maroon deltaic silty sands and silts (DSST). FDOQ beds average 1-m thick and contain kaolinite cement, authigenic quartz overgrowths and low-angle cross bedding. The laminated DSST beds contain small bleached spots and authigenic muscovite and biotite on bedding-plane partings (Babcock 1975).

The leached FDOQ bed is an example of iron-removing fluids passing the relatively wellsorted and, likewise, more-permeable beds, and serves as loci for local leaching, as noted by the leached rim around this bed.

Babcock (1975) interpreted the increase in grain size and FDOQ content as evidence for a prograding deltaic sequence. The progradation was attributable to uplift in the source area (toward the present south-southeast) and/or subsidence (toward the present northnorthwest) further "offshore." A shallow water environment was supported by "floating" quartz and shale pebbles and rippled dune-beds.

\subsubsection{Roadside Park Lacustrine}

This 16-m high, lacustrine outcrop is located at the Dillman Roadside Park, just north of and overlying the channel outcrop described previously. This outcrop is composed of silty flatbedded (B2) lacustrine sands (Babcock 1975), corresponding to Hamblin's (1956) massive sandstone facies.

\subsubsection{Pequaming Alternating}

This 7-m high outcrop is located at the northwest-facing coastal cliffs at Pequaming. Babcock (1975) described B1 facies sandstone unconformably overlying D-facies siltstones in this area. The siltstone Babcock referred to may be the brick red siltstones just north of the outcrop logged in this study. However, this outcrop does consist of sandstones overlying reddish brown siltstone layers.

\subsubsection{Keweenaw Bay Lacustrine}

Only the top $12 \mathrm{~m}$ of this lacustrine cliff outcrop were logged because of unstable talus covering the lower part of the outcrop. This outcrop is located on private property off US41 just north of the Houghton-Baraga county boundary. This outcrop is similar to the upper section of the Keweenaw Bay Lacustrine outcrop and is comprised of B2 flat-bedded, massive sandstones. Individual beds can be traced for hundreds of meters.

\subsubsection{Lacobsville Lacustrine}

This 14-m high, sandstone cliff is located on private property north of Jacobsville at the historic mining pier. This outcrop, and the type section at Jacobsville, is comprised of massive B2 facies, flat-bedded silty sands (Babcock 1975). Nearby cliffs contain channel features and oscillation ripple marks indicating fluvial influences and shallow water, suggesting a marginal lacustrine environment. 


\subsubsection{Traverse Alternating}

This 5-m high outcrop is located at the sandstone promontory between Little Traverse Bay and Big Traverse Bay and is accessible by a privately maintained trail. The outcrop is similar to Traverse Island, which was described by Babcock (1975) as comprised of alternating beds, $\mathrm{C}=\mathrm{B} 1+\mathrm{B} 2+\mathrm{D}$. Uppermost B1 facies beds exposed on the island consisted of gently folded, very competent quartzites. On the southeast side of the island, chrome mica (fushsite) was found along a bleached fracture zone. This outcrop is about 5 miles southeast of where the Rice Lake core was drilled (Section 14, T 55 N, R 32 W, Torch Lake Township). Bowers (1989) characterized the upper 400 feet of core, which was similar to outcrops, as braided or meandering channel deposits and interpreted these as alluvial plain deposits. The laminated sheet sand was interpreted as upper-flow regime and plain-bed conditions, while the siltstone was interpreted as overbank fines. The underlying core was interpreted as distal alluvial fan facies, suggesting interfingering between alluvial plain and alluvial fan deposits.

\subsubsection{Gay Alternating}

The 5-m high outcrop is on private property 1 mile north of the Tobacco River. According to Babcock (1975), an alternating bed sequence similar to Traverse Island $(C=B 1+B 2+D)$ is present near the mouth of the Tobacco River north of Gay. Northeast of Gay, at Bruneau Park, B2 facies, well-sorted fine sandstone unconformably overlies D facies siltstones.

\subsubsection{Structure and Fractures}

Fractures are important for groundwater flow in Jacobsville Sandstone aquifers. Young and Repasky (1986) identified complex structure within the Jacobsville Sandstone. Hedgeman (1992) interpreted a separate sub-basin in the Jacobsville Sandstone west of Lake Gogebic. Belliveau (1991) described three types of outcrop scale fractures in the Jacobsville Sandstone. "Shear" fractures commonly cut through clasts, have 5- to 40-cm wide leached zones into the fracture walls, are generally long, straight, near vertical and relatively smooth. Fractures perpendicular to the bedding are commonly found where there is a change in the cross-bed direction, grain size and cement; they are contained within individual strata and propagate around clasts. Thrust-generated fractures are pervasive along bedding planes where the upper masses have undergone differential movement produced by the southward movement of the glaciers.

\subsubsection{Uranium Exploration in Michigan's Upper Peninsula}

The western Upper Peninsula has a history of U prospecting, including interest in the Jacobsville Sandstone. Uranium deposits in sandstone require a U source and a favorable depositional environment (Saum and Link 1969; Finch and Davis 1985; Spirakis 1996). Deposits in a sedimentary basin may also be controlled by post-depositional fluid flow processes (Kyser and Hiatt 2003). Unconformity-related deposits often occur in mineralized, faulted metasedimentary rocks underlying younger Proterozoic sandstones (Lambert et al. 2001). The provenance of the Jacobsville Sandstone includes rocks with identified U occurrences, which could constitute a source of $U$ for the Jacobsville Sandstone. Victers (1956) documented U occurrences associated with carbonaceous slate of the

Michigamme Formation and Precambrian granite. Hoffman (1987) described the U-rich Bell Creek Granite. Kalliokoski (1976) and Johnson (1977) summarized U occurrences in the 
Upper Peninsula including $U$ mineralization in the granitic rock underlying the Jacobsville Sandstone at Big Eric's Crossing in Baraga County.

The Hydrogeochemical and Stream Sediment Reconnaissance (HSSR) component of National Uranium Resource Evaluation (NURE) analyzed groundwater samples for uranium and other elements in selected quadrangles throughout the country. The NURE report for the Iron River Quadrangle, MI, located in the western Upper Peninsula, suggested the potential for uranium mineralization in the Jacobsville Sandstone south of the Keweenaw fault and in Baraga County where it unconformably overlies Precambrian granites, gneisses and metasediments and the geology is similar to areas with known $\mathrm{U}$ deposits (Arendt and Butz, 1980a). However, no areas in the Iron River Quadrangle were considered favorable for at least 100 tons of $\mathrm{U}_{3} \mathrm{O}_{8}$ at a grade of $0.01 \%$ (Frishman et al. 1982). In the Marquette Quadrangle, MI, located in the central Upper Peninsula, the Jacobsville Sandstone was again noted for potential uranium mineralization. High uranium concentrations in groundwater were associated with high specific conductance, boron, barium, sodium and strontium (Arendt and Butz, 1980b).

Exploration for metals in Michigan's Upper Peninsula was revitalized in 2002. Mineral exploration by Vancouver based Bitterroot Resources Ltd (www.bitterrootresources.com) is of particular interest to this study. Bitterroot has drilled several cores in the Jacobsville Sandstone and determined that background $U$ concentrations average approximately $5 \mathrm{ppm}$ (Carr 2004). Cores from Bitterroot may be available in the future for academic research. It is interesting to note that in contrast to other cores east of Lake Gogebic, in which conglomerates were confined to basal layers (Hedgeman 1992), conglomerates in some Bitterroot cores occurred high in the section. Some clasts exceeded the core diameter. Basal conglomerates typically occur after renewed weathering following a period of relative quiescence. Conglomerates higher in the section indicate a higher energy environment, perhaps because the region represents a proximal alluvial fan environment. Hedgeman (1992) interpreted the presence of conglomerates west of Lake Gogebic as evidence for a separate sub-basin with a distinct tectonic history. Likewise, these cores may indicate that separate sub-basins also occurred east of Lake Gogebic.

\subsubsection{Cores with Spectral Gamma-ray Logs}

Ojakangas and Dickas (2001) described core from the Amoco Production \#1-29R test, herein referred to as the St. Amour well, and the nearby Hickey Creek well drilled by Cleveland Cliffs Mining Services. The St. Amour well is $7238 \mathrm{ft}(2410 \mathrm{~m})$ deep and 100\% cored. Ojakangas and Dickas (2001) interpreted the conformable contact between the overlying white-sandstone Munising Formation and the Jacobsville Sandstone at 521 feet. As observed on the spectral gamma-ray log, the Munising Sandstone has lower U concentrations than the Jacobsville Sandstone, and, likewise, lower groundwater U concentrations. Ojakangas and Dickas (2001) interpreted the conformable contact between the Jacobsville and underlying Freda Formation at 1979 feet, however, they noted that this was a somewhat arbitrary boundary because the abundance of hematite resulted in megascopic similarities between the two red-bed units and thin-section samples had a wide spacing. The Jacobsville was identified as a feldspatholithic sandstone and the Freda as a lithofeldspathic sandstone. The dominant lithology for both units is immature sandstone, with minor siltstone, shale and mudchip conglomerate. 
The rocks were described as typical red bed with red, browns and maroons, mottling and a few white beds, and tan to greenish reduction spots. The rock are commonly cross-bedded, some parallel bedding is also present. Fining-upward sequences were noted. Minor shales tend to be brick red, though shale laminae may be green, perhaps because they were more readily reduced. Intraformational mudchip conglomerates are also predominantly green.

Petrographic analysis agreed with other studies: the average Q:F:L ratio was 72.2/20.7/7.2. Feldspar dominated over lithics (rock fragments), some had enough feldspar to be called arkoses, but were classified as feldspatholithic sandstones so that both components appeared in the rock name. Some samples in the upper half of formation were quite quartzose. Rock fragments constituted felsic volcanic $(56 \%)$ and metamorphic rock fragments of mica schist and polycrystalline quartz $(39 \%)$, plus minor mafic volcanic rock fragments and sedimentary rock fragments of chert. Plutonic rock fragments composed of quartz and K-feldspar made up $1-2 \%$ of the grains. Other minor detrital grains, not counted in the Q:F:L ratios include opaques, epidote, zircon, apatite and garnet. Diagenesis included dominant silica and clay cementation, minor calcite and iron-oxide/leucoxene cementation and minor dissolution of feldspar. Porosity ranged from $2.1 \%$ to $27 \%$ with an average of $14.2 \%$.

Dickas and Mudrey (1999) described the Terra-Patrick \#7-22 borehole, Bayfield County Wisconsin drilled through Oronto Group. Spectral gamma-ray log showed a 10 to 15 API unit effect by uranium for the Nonesuch and Freda Formations. Assuming one API unit is about $0.08 \mathrm{ppm} \mathrm{U}$, this would be equivalent to 0.8 to $1.2 \mathrm{ppm} \mathrm{U}$, which is lower than values obtained for the Jacobsville Sandstone.

\section{METHODS}

\subsection{GROUNDWATER CHARACTERIZATION}

\subsubsection{Selection of Wells}

Approximately 270 wells were analyzed for U. Initially wells were selected based on existing elevated (unadjusted) gross alpha analyses from the Wisconsin State Laboratory obtained through the Western Upper Peninsula District Health Department by permission of the well owners. The unadjusted gross alpha tests were not reliable indicators of actual U concentrations, perhaps due to limitations of the gross alpha test or the presence of other alpha emitters, e.g., radium, in the water. However, several areas with elevated well water U concentrations were identified by testing wells with elevated (unadjusted) gross alpha results.

Subsequently, samples from wells were solicited based on areas of interest and availability of well logs from the Michigan Department of Environmental Quality (MI DEQ) website. One area of interest was the base of the Jacobsville Sandstone due to exploration interest in unconformity-related $U$ deposits. Well logs were used to identify wells that penetrated the Jacobsville Sandstone into the underlying graphitic slate. While this study focused on the Jacobsville Sandstone, some wells from surrounding formations were also sampled, 
including wells from the macroscopically similar Freda Sandstone and the U-rich provenance rocks, e.g., the Bell Creek Granite, which averages 15 ppm U (Hoffman 1987).

The NURE program had analyzed numerous wells for $U$ for exploration purposes. The NURE data was downloaded from the USGS website (Smith 2001) and incorporated into the GIS database. The NURE data included approximate coordinates and house descriptions, which enabled some wells to be reanalyzed as part of this study. In general,

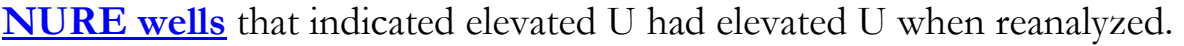

Additionally, numerous wells were included in this study by request of well owners. This included direct requests in response to newspaper articles and word of mouth as well as requests redirected by the Health Department. When well owners were notified that their wells had U concentrations above the MCL they would frequently recommend to their neighbors that they also have their wells tested. Combined with collecting samples from areas with elevated gross alpha and elevated NURE results, this may have tended to bias the representativeness of the database toward areas with wells with elevated $\mathrm{U}$.

\subsubsection{Collection of Samples}

Jacobsville Sandstone wells are uncased in the sandstone and well water represents a mixture of groundwater from numerous permeable intervals. Because samples were taken from residential wells in daily use, it generally was not necessary to purge the wells of stagnant water. Samples were typically representative of drinking water; however, samples from water treatment systems were avoided or taken in along with untreated samples for comparison. Filtration of select samples with $1-\mu \mathrm{m}$ size filter did not reduce the $U$ concentration indicating that $U$ was soluble in the water. This finding is consistent with Lee et al. (2001), who found less than $1 \%$ of total $U$ was detected in the particulate fraction and Seiler (2004) who found that $\mathrm{U}$ concentration of unfiltered and filtered water samples were nearly equal. However, additional study would be required to quantify the amount of colloidal $\mathrm{U}$ in local well water. Samples were collected in polyethylene bottles with size requirements dependant on the lab conducting the analysis. Preservation with $\mathrm{HNO}_{3}$ also depended on the lab.

\subsubsection{Uranium Analysis}

Most samples from this study were analyzed by an inductively coupled plasma-mass spectrometry (ICP-MS). The majority of samples were analyzed for isotopic $\mathrm{U}$ at the Laboratory of Isotope and Trace Element Research (LITER), at Old Dominion University. Samples were analyzed on an Element 2 ICP-MS by Finnigan-MATT. An Element 2 is housed in MTU's Forestry Department but was not yet operational during the duration of this study. Blanks, duplicates, and a blind sample prepared from a U standard (Inorganic Ventures, Inc., Lakewood, NJ) were included with the well samples. Water samples from the Chassell Village test wells were analyzed at Radiation Safety Engineering (Chandler, AZ). In the later stages of the study, requests for $\mathrm{U}$ analysis were sent to the Michigan Department of Environmental Quality (MI DEQ) Drinking Water Laboratory, which is certified to test for $U$ in drinking water but does not report $U$ isotope ratios. The reported $\underline{\mathrm{U}}$ concentrations from these laboratories were generally consistent (deviations of less than $10 \%$ ) for a given well, even for water samples collected in different years and seasons. 


\subsubsection{Redox and Geochemical Analysis}

Detailed geochemical analysis for two wells were conducted at the MI DEQ Lab. The wells were selected because of their low $(0.01 \mathrm{ppb})$ and high $(168 \mathrm{ppb}) \mathrm{U}$ concentrations. A flow cell (FC4000, QED Environmental Systems, Ann Arbor, MI) was used at numerous wells to measure oxidation-reduction potential (ORP), dissolved oxygen, conductivity, $\mathrm{pH}$, and temperature. Alkalinity was determined by titration with a field kit. Results from the geochemical analysis and flow cell measurements were entered into PHREEQCI (USGS 1998), an ion-association aqueous model with capabilities for speciation and saturation-index calculations, to determine dissolved $\mathrm{U}$ species and whether $\mathrm{U}$ minerals would dissolve or precipitate. PHREEQCI is freeware from the USGS. The acronym stands for $\mathbf{p H}$, redox, equilibrium, written in $\mathbf{C}$ programming language, and includes a user interface. In addition to speciation modeling, PHREEQCI can be used for batch-reaction modeling, transport modeling and inverse modeling. Stoichiometric and thermodynamic data for aqueous species and pure phases are contained in database files distributed with PHREEQCI. In this study, the minteq.dat database was used because it contains data on $U$ phases. PHREEQCI uses the Newton-Raphson method to iteratively determine a solution for a set of nonlinear equations including activity-coefficients, mass-action and mass-balance equations for aqueous complexes.

\subsubsection{CFC Groundwater Age Dating}

Chlorofluorocarbons (CFCs) are stable compounds of anthropogenic origin used as refrigerants, solvents, and aerosol propellants. CFCs have accumulated in the atmosphere and recharged into the groundwater at known concentrations since the 1940s. CFCs have been used to age-date groundwater since the 1970s (Busenberg and Plummer 1992). Samples for CFC analysis were collected in glass bottles that were flushed and capped with foil-lined caps underwater in a beaker (USGS 2003). Samples were analyzed by gas chromatograph at the University of Utah Dissolved and Noble Gas Laboratory.

\subsection{HOST ROCK CHARACTERIZATION}

\subsubsection{Gamma Ray Spectrometry of Wells and Outcrops}

A GRS 2000 gamma-ray spectrometer was rented from the manufacturers, GF Instruments, in the Czech Republic. The gamma-ray spectrometer utilizes the characteristic gamma energies of the U-series, Th-series and $\mathrm{K}-40$ to calculate equivalent $\mathrm{U}(\mathrm{eU})$, equivalent $\mathrm{Th}$ (eTh) and $\mathrm{K}$ in wells and at outcrops. The eU concentrations are the same as actual $\mathrm{U}$ concentrations if the U-series is in equilibrium. Equilibrium analysis of samples from the Jacobsville Sandstone core indicated that the U-series was in equilibrium. However, an outcrop sample showed disequilibrium, probably due to weathering effects. Gamma-ray spectroscopy is used routinely in the petroleum industry to identify U-rich fractures and clay type in boreholes (Gearhart Industries 1986). Gamma-ray spectroscopy has been used in groundwater studies to correlate layers (Buckley and Oliver, 1990) and is used at outcrops to characterize facies in terms of $\mathrm{K}(\%), \mathrm{eU}(\mathrm{ppm})$ and $\mathrm{e}$ Th $(\mathrm{ppm})$ and their ratios (Bristow and Myers, 1989; Davies and Elliot, 1996; North and Boering, 1999; Ehrenberg and Svana, 2001).

Twelve wells (Figures $\underline{30}$-53) were logged with the gamma-ray spectrometer to determine if there was a correlation between groundwater $U$ concentration and $U$ concentrations in the 
aquifer host rock. When available, the depth of casing (black line), top of sandstone (hatched symbol) and water (inverted blue triangle) are indicated on the logs. Logs of $\mathrm{K}$ and Th were used to distinguish types of $U$ occurrences in aquifer host rock, e.g., $U$ associated with heavy minerals versus $U$ enrichment due to fluid flow. Selection of wells was based on the $U$ concentration of the well water (both low $U$ and high $U$ wells were logged), ability to obtain permission from well owners, access for a drilling rig to remove the water pump, or preferably, absence of a pump in the well.

Ten sandstone cliff outcrops (Figures 11-29) located along Lake Superior, were logged with the gamma-ray spectrometer to determine if a correlation between rock $U$ concentrations and depositional and lithologic facies could explain the distribution of elevated groundwater U anomalies. Several of the outcrops were located near tested wells, including some that produced water with elevated U. However, the deep wells penetrated strata not exposed at the cliffs. The Jacobsville Lacustrine outcrop was near well GW 4, which had 32.13 ppb $\mathrm{U}$ and was 260-ft deep. The Gay Alternating outcrop was near GW 67, which had 75.17 ppb U and was 120-ft deep. The Keweenaw Bay Deltaic Channel and Roadside Park Lacustrine were near a shallow hand pump (GW 71) that produced $1.95 \mathrm{ppb}$ U, a shallow (68 ft) well (GW 218) that produced $15.72 \mathrm{ppb} \mathrm{U}$ and a deep $(240 \mathrm{ft})$ well that produced $56.11 \mathrm{ppb}$ U. The Keweenaw Bay Lacustrine outcrop was near a shallow (87 ft) well (GW 311) that produced $8.8 \mathrm{ppb}$ U.

Readings in wells were generally taken every $20 \mathrm{~cm}$. At outcrops, readings were taken every $20 \mathrm{~cm}$ to $1 \mathrm{~m}$, depending on changes in lithology. Readings were taken for two minutes, which gave an average Root Square Deviation (RSD) of about $27 \%$ for $U$ and Th and $1 \%$ for $\mathrm{K}$. Intervals with relatively high radioactivity produced a higher number of counts, which decreased the RSD for these intervals.

\subsubsection{Analysis of Core and Outcrop Samples}

In this study, the St. Amour core and the corresponding spectral gamma-ray log run in the borehole were examined. Half of the split core is housed at the Core Repository in Marquette. A photocopy of the spectral gamma-ray log, in API units, which included traces of the combined Th, $\mathrm{U}$ and $\mathrm{K}$ and $\mathrm{U}$ free curves, was obtained. The paper curves were scanned and digitized in Log ASCII Standard (LAS) so that they could be displayed and formatted with Interactive Petrophysics software. A curve of U concentration was calculated using the difference of the combined and $U$ free logs and a conversion assuming 1 API unit of $U$ is approximately 0.08 ppm $U$. Logs with separation of $K$ and Th were not available. The entire Jacobsville Sandstone portion of the core was photographed. The digitized Amoco Log file and photographs of core are available in the supplementary files.

Intervals of core corresponding to $U$ peaks on the log were further analyzed by thin section at Michigan Technological University. The fine fraction from core samples was analyzed by $\mathrm{x}$-ray diffraction (XRD) to obtain illite percents (illite/(illite+smectite)). Core samples were analyzed at Geoanalytical Laboratories SRC, Saskatoon, Saskatchewan for total U (total digest) and leachable $U$ (partial digest) by fluorimetry. Additionally, 11 rock-chip samples from the Rice Lake core were analyzed for $U$ and other elements at Act labs. 
Thin sections were made from outcrop samples to determine the mineralogy associated with characteristic $\mathrm{K}, \mathrm{U}$ and Th concentration and ratio curves to aid in interpreting these curves on well logs, where visual assessment of the sandstone was not possible. Samples containing $\mathrm{U}$ enrichment associated with Th were investigated to determine if $\mathrm{U}$ was in a primary phase associated with other heavy minerals. In addition, samples with $\mathrm{U}$ enrichment relative to Th and $\mathrm{K}$ were characterized to determine if primary $\mathrm{U}$-bearing minerals were present or alternatively if the $\mathrm{U}$-enrichment could be inferred to be secondary $\mathrm{U}$ mineralization precipitated by groundwater flow.

\section{RESULTS AND DISCUSSION}

\subsection{RESULTS FROM GROUNDWATER CHARACTERIZATION}

\subsubsection{Distribution of Uranium in Groundwater}

Approximately $25 \%$ of the 270 wells analyzed in this study produced water with $\underline{\mathbf{U}}$ concentrations above the MCL. Approximately $7 \%$ of wells produced water with $\mathrm{U}$ concentrations over $100 \mu \mathrm{g} / \mathrm{L}$. An expanded view of the distribution of $U$ in groundwater is available in the supplementary files. The average well water $U$ concentration was $25 \mu \mathrm{g} / \mathrm{L}$ and the median was $8 \mu \mathrm{g} / \mathrm{L}$. Jacobsville Sandstone wells with elevated U occurred throughout the Jacobsville Sandstone from Ontonagon to the Keweenaw Peninsula and to Sault Ste. Marie. While our study focused on wells completed in the Jacobsville Sandstone bedrock, elevated $U$ was also found in wells in surrounding formations, including the Freda Sandstone and Archean granites and gneiss. Wells drilled through the unconformity at the base of the Jacobsville Sandstone into underlying graphitic slates did not produce $U$ above the MCL.

Water samples collected from surficial wells (completed in the overlying glacial drift), which were more common during the 1970s, as part of the NURE program, had U concentrations below the MCL. Similarly, the relatively small number of surface wells in this study had low $\mathrm{U}$ concentrations, indicating that elevated $\mathrm{U}$ was generally associated with bedrock wells. However, surficial deposits may affect recharge rates, groundwater chemistry and $U$ solubility. The distribution of $U$ in well water is shown in relation to Quaternary deposits. Wells in the Freda sandstone with elevated U concentrations occur primarily in areas overlain by lacustrine clay and silt, e.g., near Ontonagon. Areas where the Freda sandstone is overlain by coarse-textured glacial till, e.g., near the west entry of Portage Canal, produce water with low $U$ concentrations. Elevated $U$ in Jacobsville Sandstone aquifers occurs in areas overlain by coarse-textured glacial till and lacustrine sand and gravel. Elevated U occurs in granitic aquifers overlain by thin to discontinuous till. Elevated $\mathrm{U}$ in groundwater has been attributed to Lake Agassiz clay deposits (Betcher et al. 1988), and Frishman et al. (1982) suggested that thick lacustrine clays might be responsible for elevated radioactivity in the area.

Repeated sampling of wells in this study and sampling of wells from the NURE program indicated that well water $U$ concentrations are generally consistent over time, even when sampled in different years and seasons. 
Uranium concentrations above the MCL frequently occurred in clusters so that neighboring wells tended to have similar $U$ concentrations. A linear anomaly of elevated $U$ was found in the Houghton-Chassell area where wells near Portage Lake produced U above the MCL, while wells on the west side of US-41 at higher elevations produced U below the MCL. This localized linear feature might be explained by differences in well bottom elevations. Wells drilled deeper than ca. $500 \mathrm{ft}(150 \mathrm{~m})$ amsl produced water with $\mathrm{U}$ concentrations above the MCL.

\subsubsection{Uranium Isotope Ratios}

The ${ }^{235} \mathrm{U} /{ }^{238} \mathrm{U}$ ratios of well water samples were consistent with naturally occurring $\mathrm{U}$ (mean mass ratio of 0.0072$) .{ }^{234} \mathrm{U} /{ }^{238} \mathrm{U}$ activity ratios varied from near secular equilibrium to as high as 16, with an average of 2.25 and median of 1.75 . The distribution of ${ }^{234} \underline{\mathbf{U} /}{ }^{\underline{238}} \underline{\mathbf{U}}$ activity ratios indicates that neighboring wells tend to have similar values. In some areas, ${ }^{234} \mathrm{U} /{ }^{238} \mathrm{U}$ activity ratios vary inversely with $\mathrm{U}$ concentrations, while in others they vary directly. ${ }^{234} \mathrm{U} /{ }^{238} \mathrm{U}$ activity ratios were plotted versus the reciprocal of $\mathrm{U}$ concentration to elucidate possible dilution and mixing trends and controls on groundwater $U$ concentrations. Neighboring wells plot in clusters that may overlap with wells from other regions with similar rock-water interactions. Horizontal trends (parallel to the $1 / \mathrm{U}$ axis) within a region are interpreted as varying degrees of $\mathrm{U}$ dilution. Trends from the lower left corner to upper right may be interpreted as mixing of high $U$ / low AR groundwater with low $U$ / high AR groundwater or progressive dissolution of the host rock (AR approximately 1).

The Houghton-Chassell area wells that produced water with $\mathrm{U}$ concentrations above the MCL tend to have low activity ratios $(<2)$, perhaps indicating strong dissolution rates that would make recoil-derived ${ }^{234} \mathrm{U}$ relatively less important. The correlation between high $\mathrm{U}$ concentration and low activity ratio is consistent with findings from other studies. Wells in the Houghton-Chassell area with low groundwater $U$ concentrations frequently had high ${ }^{234} \mathrm{U} /{ }^{238} \mathrm{U}$ activity ratios. Previous studies showed that this relationship is common in areas with stable $\mathrm{U}$ deposits, e.g., redox fronts. However, because these wells produce oxidized groundwater, another mechanism, e.g., influence of the vadose zone or low weathering rates, is required to explain the observed $U$ isotope variations. Isotopic analysis of water from the vadose zone could determine the influence of this water on groundwater activity ratios.

CFC dating indicates relatively young groundwater in this area, which supports the model of vadose influence.

In other parts of the study area, e.g., east if Skanee and the Keweenaw Bay Community, some wells that produced U concentrations above the MCL had high activity ratios $(>2)$. This relationship is less commonly reported in the literature and may indicate differences in the rock-water interactions or possibly long groundwater residence times. These wells frequently plot in horizontal trends (parallel to the $1 / \mathrm{U}$ concentration axis), which may be an indication of $U$ dilution trends. The wells east of Skanee and near the Keweenaw Bay Community plot in overlapping fields, which may indicate similar rock-water interactions. Additional AR plots with less recognizable trends are provided in the supplementary files.

\subsubsection{Geochemistry}

Variations in redox conditions can exert strong control on groundwater U solubility. Well water in this study was consistently oxidized with Eh values of 0.3 to $0.5 \mathrm{~V}$, indicating the 
potential for high $\mathrm{U}$ solubility. The alkalinity of these waters averaged approximately 175 ppm and varied from 592 to $26 \mathrm{ppm}$ as $\mathrm{CaCO}_{3}$. Chemical analyses from the MI DEQ Drinking Water Laboratory for a well (GW 18) with high U (167.9 ppb in this analysis) and a well (GW 49) with low $\mathrm{U}$ (0.01 ppb) were entered into PHREEQCI to model U species and saturation indices of $U$ minerals. It was assumed that the partial pressure of $\mathrm{CO}_{2}$ in groundwater was $10^{-2}$, which is consistent with reported values (Langmuir 1997). Total U (molar concentrations) for each valence state were calculated, as well as concentrations for individual $\mathrm{U}$ species. Molar $\mathrm{U}$ concentrations can be converted to $\mu \mathrm{g} / \mathrm{L}$ (ppb) using the molecular weight of $\mathrm{U}(238 \mathrm{~g} / \mathrm{mol})$. The model output includes the mineral phase, saturation index (SI), the log of the ion activity product (IAP), the log of the equilibrium constant (KT) and the chemical composition of the phase. The saturation index is the log of the ratio IAP/KT. A positive saturation index indicates the phase is saturated, while a negative value indicated the phase is undersaturated.

PHREEQCI output for GW18, which is probably more representative of wells in this study, indicated that $\mathrm{U}$ was complexed with carbonates. These negatively charged carbonate complexes might limit $\mathrm{U}$ sorption to iron oxides and result in higher groundwater $\mathrm{U}$ concentrations. This well had $500 \mathrm{ppb}$ vanadium resulting in positive saturation indices for the uranyl vanadates, carnotite and tyuyamunite. Thus, V may limit U solubility in some groundwater, through the precipitation of carnotite and tyuyamunite, though at $\mathrm{U}$ concentrations above the MCL. Chemical analysis of GW49 indicated low concentrations of major groundwater constituents, which is consistent with its location in a recharge area. PHREEQCI output for GW49 indicated U phosphate complexes dominated over carbonate complexes. Uranium was undersaturated with respect to common U minerals.

\subsubsection{CFC Age Dating of Groundwater}

Apparent groundwater ages, in this study based on CFC dating, may help explain spatial trends in groundwater U concentrations. The PLAKE2 well, located where groundwater discharges into Portage Lake, produced U above the MCL $(82 \mu \mathrm{g} / \mathrm{L})$ and shows CFCderived apparent groundwater ages ( $>50$ years) near and exceeding the older limit of the dating method. The HILLTOP well, which is located near the top of the topographic divide, produced water with extremely low $\mathrm{U}(0.05 \mu \mathrm{g} / \mathrm{L})$ and showed CFC derived apparent groundwater ages near modern ( $<2$ years). Age dating of the HILLBTM well, which is in between the other two along the assumed direction of regional groundwater flow, was inconclusive and may have been contaminated with atmospheric CFC. Groundwater residence time, and likewise, topography, may influence the distribution of $U$ in groundwater. However, examining the distribution of $U$ in groundwater to in relation to topography indicates that not all wells in recharge areas have low $\mathrm{U}$ concentrations.

\subsection{RESULTS FROM HOST ROCK CHARACTERIZATION}

\subsubsection{Lateral Continuity of Uranium in the Jacobsville Sandstone}

Twelve wells were logged with a spectral gamma-ray probe to characterize the $\mathrm{U}$ concentration in the host rock in the near vicinity $(20 \mathrm{~cm})$ of the well bore. Whether or not $\mathrm{U}$ concentrations in the sandstone are laterally continuous beyond the range of the spectrometer likely depends on local depositional facies. Channel outcrops, e.g., Keweenaw

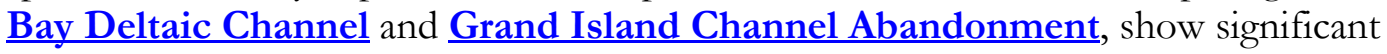


horizontal variation in lithology and $\mathrm{U}$ concentration, however, lacustrine and sheet-flood outcrops are generally laterally continuous over hundreds to thousands of feet. Likewise, strong correlation between log curves for CHASHILL2 and CHASHILL3 indicate that relatively U-rich strata are laterally continuous for over 100 feet. Groundwater may also be in contact with U-rich strata for hundreds of feet, though vertical fractures may reduce strata-bound flow. Correlation of log curves for wells that are farther apart is less certain. Well logs are shown positioned in relation to sea level (an expanded image is in the supplementary files). The HILLBTM well, located approximately two miles to the north of the CHASHILL wells, is at the same elevation but its log shows much lower U concentrations. The three wells along Portage Lake (PLAKE1, 2, 3) show relatively higher $\mathrm{U}$ in the lower portions of their logs, so these may tentatively correlation. The HILLTOP and AIRPRTRD wells are both at approximately the same elevation and both show low U on their logs, but they are too far apart to correlate without more data in between.

\subsubsection{Comparison of Uranium Concentration in Well Water and Host Rock}

Spectral gamma-ray data has been summarized for all of the logged wells. In some wells there appears to be a correlation between well water $\mathrm{U}$ concentration and the $\mathrm{U}$ concentration of the host rock. Three of the logged wells, PLAKE1, PLAKE2 and $\underline{\text { PLAKE } 3}$, are part of the linear anomaly of elevated U along Portage Lake between Houghton and Chassell. These wells all show eU values above $5 \mathrm{ppm}$ and the PLAKE2 well shows a spike of $22 \mathrm{ppm}$, which is at the same depth as the pump. Similar U-rich strata may have been encountered by groundwater prior to reaching the PLAKE1 and PLAKE3 wells. The KBAYCOM well near the Keweenaw Bay Community had intervals of eU above 5 $\mathrm{ppm}$ in the host rock and produced water with $\mathrm{U}$ concentrations near the MCL (25.1 ppb).

However, in some wells, effects from elevated $U$ in the host rock are apparently modified by other factors, resulting in only moderate well water $U$ concentrations. Two of the Chassell Village's new test wells, CHASHILL2 and CHASHILL3, show elevated eU on their logs and produced water with U near $10 \mathrm{ppb}$. CHASHILL4 shows relatively greater elevated eU on its $\log$ and produced water with $18.6 \mathrm{ppb} \mathrm{U}$, which is somewhat elevated, though below the MCL. A neighboring well in the cluster produced $20.7 \mathrm{ppb}$ U. The PEQUAMING well $\log$ shows frequent intervals above $5 \mathrm{ppm}$ eU and produced water with moderate $\mathrm{U}$ concentration (11 ppb).

The HILLBTM well, which is $140 \mathrm{ft}(43 \mathrm{~m})$ above Portage Lake, produced water with low $\mathrm{U}$ concentration $(1.19 \mu \mathrm{g} / \mathrm{L}$ ) and had low $\mathrm{U}$ (eU is consistently below $5 \mathrm{ppm}$ ) in the host rock. The HILLTOP well, approximately $300 \mathrm{ft}(90 \mathrm{~m})$ above Portage Lake, produced water with extremely low U concentration $(0.05 \mu \mathrm{g} / \mathrm{L})$ and, except for a small spike, shows generally low eU.

Some wells without evidence of elevated $\mathrm{U}$ in the host rock produced water with elevated U. The CHASLAKE well, located down hill from the other Chassell test wells, was abandoned based on $\mathrm{U}$ levels in the water but did not show high $\mathrm{U}$ on the log (the upper portion represents casing in surficial material). It is likely that the groundwater flow path passed through U-enriched strata, as higher readings were found up gradient in the Chassell Village test wells. 
The AIRPRTRD well log shows eU below $5 \mathrm{ppm}$. At this time, a pump has not been installed in the well so no water analysis is available.

\subsubsection{Distribution of Uranium in Jacobsville Sandstone Outcrops}

Analysis of spectral gamma-ray measurements by grain size indicates that clayey/shale samples have the highest average $\mathrm{U}(5.2 \mathrm{ppm})$ followed by sandstones with mud chip conglomerates and minor clay $(4.2 \mathrm{ppm})$. Clays and shales occur in abandonment facies and over bank deposits. Mud chip conglomerates occur in overlying sandstones where current ripped up and incorporated the finer underlying material. Mud chips occur both in their original red color and in gray-green, where iron-removing fluids have leached the formation. Uranium is on average higher in samples containing clay, however, relatively high $\mathrm{U}$ concentrations (above $4 \mathrm{ppm}$ ) were measured in association with all grain sizes.

The spectral gamma-ray data are summarized for the 10 outcrops. It was anticipated that outcrops with alternating lithologic facies would show a positive correlation of $U$ with the interbedded red siltstones and shales (Western Upper Peninsula Health Department 2001). The Pequaming Alternating outcrop shows relatively higher $U$ associated with the lower finer grained portion of the cliff. However, the Gay Alternating outcrop does not show a correlation of $U$ with the red finer grained layers. At the Traverse Alternating outcrop, some relatively high measurements were associated with coarse white sandstone layers as well as interbedded siltstone layers.

Uranium concentrations above 5 ppm were measured in all outcrops except the L'Anse Main Channel and Keweenaw Bay Lacustrine, and included alluvial fan deposits, deltaic channels and lacustrine deposits. This suggests that the heterogeneous distribution of $U$ in the Jacobsville Sandstone is not isolated to specific depositional environments. Excluding the L'Anse Unconformity outcrop (which included readings from the underlying Michigamme slate), the highest mean U concentrations occur in the Keweenaw Bay Deltaic Channel and Pequaming Alternating outcrops (both $4.4 \mathrm{ppm} \mathrm{eU}$ ). The highest single reading (12.5 ppm eU) was at the Keweenaw Bay Deltaic Channel outcrop, near the edge of the channel. The lowest mean $\mathrm{U}$ concentrations were found at the Keweenaw Bay Lacustrineoutcrop (2.4 ppm eU) and the L'Anse Main Channel outcrop. The lowest U reading (1.4 ppb eU) was from the Jacobsville Lacustrine.

Outcrops with the most variation in $\mathrm{U}$ concentrations, indicated by relative standard deviation (RSD), were the Keweenaw Bay Deltaic Channel (47\%), the Jacobsville Lacustrine (46\%) outcrops. The Keweenaw Bay Lacustrine and L'Anse Main Channel outcrops showed less variation $(26 \%)$.

Although it is not clear what factors control the heterogeneous distribution of $U$ on a regional scale, the observation that some outcrops show $U$ enrichment while others do not may partly explain why some regions of the study area have higher groundwater $U$ concentrations than others.

\subsubsection{Distribution of Potassium and Thorium in the Jacobsville Sandstone}

Potassium is generally associated with micas, feldspars and clays (Davies and Elliot 1996). Potassium measurements from outcrop logging were highest in medium grained sandstone 
$(5.8 \% \mathrm{~K})$ and clay/shale $(5.7 \% \mathrm{~K})$, suggesting that percent $\mathrm{K}$ cannot be used to distinguish clay from sandstone within the Jacobsville Sandstone. The Grand Island Channel

Abandonment outcrop had the highest mean K (6.6\%). The highest $\mathrm{K}$ reading $(6.9 \%)$ was from the Keweenaw Bay Deltaic Channel outcrop. The lowest mean K (3.1\%), lowest reading $(1.8 \%)$ and highest RSD (30\%) were all from the Pequaming Alternating outcrop. The lowest RSD was from the Keweenaw Bay Lacustrine outcrop (7\%).

Thorium is insoluble and generally associated with resistant minerals (Davies and Elliot (1996). Quartz and feldspar only contribute 2 ppm Th (Myers and Bristow 1989). Mean Th concentrations from well and outcrop logs were above $2 \mathrm{ppm}$, indicating the presence of heavy minerals. Outcrop measurements, grouped by grain size, shows that Th is on average highest associated with mica $(8.0 \mathrm{ppm})$ and coarse sandstones $(7.9 \mathrm{ppm})$, these readings were influenced by the Traverse Alternating outcrop where mica occurs with coarse sandstone. Clay and shale layers also had high Th $(7.4 \mathrm{ppm})$. Both the highest mean Th (10.1 ppm eTh) and highest reading (14.2 ppm eTh) were from the Pequaming Alternating outcrop. Similarly, the PEQUAMING well had the highest mean Th. Both the lowest mean (4.5) and lowest RSD (16\%) were from the Keweenaw Bay Lacustrine outcrop. The highest RSD (48\%) was from the Roadside Park Lacustrine outcrop. The lowest reading (1.7 ppm eU) was from the Traverse Alternating outcrop.

Spikes on the Th curves may indicate a heavy mineral or shale layer. Where $\mathrm{U}$ is associated with Th the $\mathrm{U}$ may also be in a heavy mineral phase or shale. For example, the only $\mathrm{U}$ spike above $5 \mathrm{ppm}$ on the HILLTOP well $\log (7.9 \mathrm{ppm})$ is associated with a large Th spike $(28.8$ ppm), which could be interpreted as a heavy mineral bed or shale layer. Uranium and Th have a correlation coefficient of 0.94 for this well log. Uranium associated with heavy minerals is relatively less soluble (Durance 1984) and $U$ in shale is less readily leached due to the low permeability of shales. Thus, either a heavy mineral or shale layer, combined with very low groundwater residence time (as determined by $\underline{\mathbf{C F C}}$ dating), could help explain this well's extremely low $(0.05 \mathrm{ppb})$ well water U concentration.

In contrast, the 22.2-ppm U spike on the PLAKE2 well log is associated with a relatively low $(6.1 \mathrm{ppm})$ Th concentration. If $U$ in this interval is associated with heavy minerals, the primary U bearing minerals (e.g., zircon) must have been enriched relative to the Th-bearing minerals. Alternatively, secondary $\mathrm{U}$ mineralization, e.g., of carnotite, may have been controlled by fluid flow. Uranium and Th have a lower correlation coefficient (0.56) in this well than the HILLTOP well. Uranium occurrences emplaced by fluid flow are likely more soluble than $\mathrm{U}$ occurrences associated heavy mineral layers. This, combined with long groundwater residence time, may help explain this well's high ( $82 \mathrm{ppb})$ water U concentration.

However, the assumption that well logs with a strong positive correlation coefficient between $\mathrm{U}$ and $\mathrm{Th}$ indicate $\mathrm{U}$ is bound in heavy minerals and insoluble is not true for all wells. The PLAKE1 well log has a positive correlation coefficient between $\mathrm{U}$ and Th $(0.9)$ and produces water with high $\mathrm{U}$ (54.1 ppb). 


\subsubsection{Interpretation of Uranium Occurrences Using Ratio Curves}

\subsubsection{Th/K Ratios}

Because $\mathrm{Th} / \mathrm{K}$ ratios are characteristic of specific clays, $\mathrm{Th} / \mathrm{K}$ plots are used in the petroleum industry to identify clay type in boreholes (Gearhart Industries 1986, Schlumberger 2000). Outcrop logs plot most frequently in the glauconite and illite fields. Most of the well log readings fall largely in the illite field on Th/K plots, e.g., CHASHILL2 Th/K Plot. Ratio curves are located directly below the main figure for each outcrop. Th/K plots for all outcrops and wells in provided in the supplementary files. Interpretation of illite as a major clay type agrees with the XRD analysis of samples from the Amoco core (McDowell 2004). High Th concentrations associated with heavy minerals may also affect the Th/K ratios, e.g., the Pequaming Alternating outcrop, which has the highest Th concentration also has the highest $\mathrm{Th} / \mathrm{K}$ ratio.

\subsubsection{Th/U Ratios}

All outcrop and well logs indicated that $\mathrm{U}$ was enriched relative to Th after the sandstone material was weathered and transported from provenance rocks. Terrestrial igneous rocks generally have Th/U ratios of 3.8 (Davies and Elliot 1996). Even the U-rich Bell Creek Granite, located to the south of the Jacobsville Sandstone has a high Th/U ratio of 4.9 (Hoffman, 1987). Thus, assuming source rocks for the Jacobsville sandstone had Th/U ratios of at least $3, \mathrm{U}$ in the sandstone exceeding one third of the Th concentration can be attributed to secondary $U$ enrichment. The Th versus $U$ grain size plot indicates that the sandstone has been enriched in $U$ relative to typical source rocks. In half of the outcrops, $U$ concentrations exceeded Th concentrations in at least one measurement. The Keweenaw Bay Deltaic Channel outcrop had the lowest mean Th/U ratio (1.4), indicating the highest relative U enrichment. The Pequaming Alternating and Traverse Alternating outcrops showed the highest $\mathrm{Th} / \mathrm{U}$ ratios (both 2.4). The Traverse Alternating outcrop also had the highest reading of $\mathrm{Th} / \mathrm{U}$ (4.8).

Intuitively, wells with lower $\mathrm{Th} / \mathrm{U}$ ratios (greater $\mathrm{U}$ enrichment) would be more likely to produce water with elevated U. However, the PLAKE2 well, which produces water with U above the MCL, has the same mean Th/U (1.3) as the CHASHILL2 and CHASHILL4 wells, which produce water with moderate U concentrations, but below the MCL.

\subsubsection{U/K and Th/U Cross Over}

Locations of $\mathrm{U}$-enrichment in fractures relative to Th and $\mathrm{K}$ is determined in the petroleum industry by plotting ratio curves of $\mathrm{U} / \mathrm{K}$ and $\mathrm{Th} / \mathrm{U}$ and observing areas of cross over $(\mathrm{U} / \mathrm{K}$ $>$ Th/U) (Gearhart Industries 1986). Outcrops that showed cross over, beginning with the highest percent of cross over, were the Keweenaw Bay Channel (not displayed because of grid sampling), Jacobsville Lacustrine, Pequaming Alternating and Grand Island Channel outcrops. U-enrichment at the Keweenaw Bay Channel outcrop appears to be associated with fluid flow along the relatively permeable channel structure, while Uenrichment at the Jacobsville Lacustrine outcrop may be due to fluid flow along dune form boundaries. Uranium enrichment at Grand Island Channel outcrop may be a combination of fluid enrichment and abandonment facies on edges that are highly adsorbing. 
Unlike outcrop logs, all well logs indicated cross over $(\mathrm{U} / \mathrm{K}>\mathrm{Th} / \mathrm{U})$, perhaps because the probability of strata with $\mathrm{U}$ enrichment increased with distance logged and the well logs were longer than the outcrop logs. It may seem that wells with higher U-enrichment $\%$ cross over) should produce water with higher U concentrations. However, the HILLBTM well $\log$ shows cross over in $48 \%$ of readings but produces water with only $1.19 \mathrm{ppb}$ U.

\subsubsection{Correlation of $\mathrm{U}$, Th and $\mathrm{K}$}

\subsubsection{U and Th correlation}

If $U$ and Th are both associated with similar phases, e.g., heavy minerals or clays, their logs will show similar deflection. Logs of $U$ and Th have a strong positive correlation coefficient at the Roadside Park Lacustrine outcrop (0.89), the Traverse Alternating outcrop (0.77), the Gay Alternating outcrop (0.76), the Keweenaw Bay Lacustrine outcrop (0.72) and the Pequaming Alternating outcrop (0.62). The Grand Island Channel outcrop has a negative ($0.12)$ correlation coefficient.

\subsubsection{U and $K$ correlation}

Logs of $\mathrm{U}$ and $\mathrm{K}$ have strong positive correlation coefficients at the Gay Alternating outcrop (0.92), Pequaming Alternating outcrop (0.79) and Traverse Alternating outcrop (0.7). Negative correlation occurs at the Grand Island Channel outcrop (-0.07) and the L'Anse Main Channel outcrop (-0.06)

\subsubsection{Th and $K$ correlation}

Th and $\mathrm{K}$ may vary together if they occur in similar detrital or clay phases. Strong positive correlation occurs at Traverse Alternating (0.93), Pequaming Alternating (0.79), Gay Alternating (0.73), and Jacobsville Lacustrine (0.71).

\subsubsection{4 $U$ and $T h / K$ correlation}

If $\mathrm{U}$ is associated with differences in clay type (as indicated by $\mathrm{Th} / \mathrm{K}$ ratios) these curves may show positive correlation. Alternatively, if both $U$ and Th occur together in a heavy mineral phase, this may also result in correlation. Outcrops with positive correlation coefficients are the Roadside Park Lacustrine outcrop (0.87), the Traverse Alternating outcrop (0.76) and the Keweenaw Bay Lacustrine outcrop (0.66). Because these outcrops show positive correlation of $\mathrm{U}$ and $\mathrm{Th}$, the correlation of $\mathrm{U}$ and $\mathrm{Th} / \mathrm{K}$ is probably not associated with changes in clay type.

\subsubsection{Core and Outcrop Samples}

Preliminary thin section analysis, XRD analysis and chemical analysis of Jacobsville Sandstone from the Rice Lake core and Amoco core were conducted to characterize U occurrences in the sandstone.

Analysis of core samples from the Amoco test well indicated that leachable U correlated with total $\mathrm{U}(0.78)$. Thus assuming similar hydrologic conditions, intervals in the Jacobsville Sandstone with relatively high $\mathrm{U}$ concentrations should tend to contribute higher $\mathrm{U}$ concentrations to the groundwater. Laboratory analysis of leachable $U$ by partial acid digest produces higher $U$ concentrations than would be leached by groundwater. 
XRD analysis of the fine fraction from 23 samples indicated the clay type in the Jacobsville Sandstone is primarily illite (mean 79, max 94, min 63) with lesser amounts of smectite. The illite present was likely converted from smectite. Wells typically show an increase of illite percent with depth, however illite percents are sporadic in the Amoco core (McDowell 2004). Comparison of total U concentrations and percent illite did not show a strong correlation. Likewise, there was no correlation between the percent leachable $U$ (partial $\mathrm{U} /$ total $\mathrm{U}$ ) and the illite percent (0.06), indicating that clay type is not a strong control on the distribution of $\mathrm{U}$ in the sandstone.

The spectral gamma-ray log from the Amoco core was used to identify intervals in the core with relatively high $\mathrm{U}$. The digitized $\log$ and photos of the entire core are included in the supplementary files. There is not always good agreement between $U$ concentrations determined from the log and measured in the lab. This could be, in part, because the spectral gamma-ray log was in motion during readings and values represent an average over 2 -feet intervals, the spectral gamma-ray log represents measurements of the borehole, while laboratory analysis was done on the core, and the U-series may not be in equilibrium. Photos of thin sections from the Amoco core and outcrop samples, labeled by depth (feet) and including laboratory and field measurements of $U$ are included in supplementary files.

The highest laboratory $U$ measurement was from a sample of red very fine sandstone with heavy mineral bands, which likely represent a lag deposit, at a depth of $\mathbf{2 1 6 2 . 4}$ feet in the Amoco core. This sample was selected based on a high (9 ppm U) log reading. Lab analysis indicated approximately $30 \mathrm{ppm}$ total $\mathrm{U}$, and $10 \mathrm{ppm}$ partial U. The opaques (likely hematite or magnetite) in this sample are well rounded and pitted indicating secondary dissolution (Mankowski 2004). High relief minerals associated with the opaques are likely zircons, which may account for the elevated $U$ in this sample (Kramer 2004). Other Amoco core thin section samples with heavy mineral layers and elevated $U$ include $2354.8 \mathrm{ft}$ (9 ppm U on log) and two Freda Sandstone samples $3540.3 \mathrm{ft}$ (14.5 ppm U, lab analysis) and $4609.5 \mathrm{ft}$ (7.7 ppm U, lab analysis). Not all samples with heavy minerals appear to have elevated U, e.g., a thin section from $1456.5 \mathrm{ft}$ shows abundant heavy mineral layers but the corresponding interval on the log has relatively low $\mathrm{U}(3.3 \mathrm{ppm})$. Further, zircons occur as inclusions in quartz grains, e.g., Traverse outcrop, and are therefore not always associated with heavy minerals layers.

Relatively high $\mathrm{U}$ measurements from core samples were also associated with clayey samples and sandstone with rip up conglomerates, which is consistent with spectral gamma-ray measurements at the outcrops, e.g., Grand Island outcrop. A sample from $2385 \mathrm{ft}$, which shows surprisingly good agreement between the log value (10-ppm $U$ ) and lab analysis (10.8 ppm), contains abundant clay as well as very fine-grained heavy minerals. The sample may represent an abandonment or overbank facies. Numerous intervals containing clayey layers and rip-up conglomerates were selected for thin sections based on elevated $\mathrm{U}$ on the log including: $1068.7 \mathrm{ft}$ (6.5 ppm U lab analysis), $1090.8 \mathrm{ft}(10 \mathrm{ppm} \mathrm{U} \mathrm{log}), 1147 \mathrm{ft}$ (3.7 ppm U lab, 10 ppm U log), $1628.1 \mathrm{ft}$ (4.6 ppm U lab, > 10 ppm log), $1875 \mathrm{ft}$ (10 ppm U log), 1938.8 ft (4.8 ppm U lab, 5.3 ppm U log) and $2356.1 \mathrm{ft}$ (6 ppm U log).

Intervals with elevated $U$ occurred in association with mica, e.g., $1512.1 \mathrm{ft}(7.3 \mathrm{ppm} \mathrm{U} \log$ ) a sample of very fine red and gray sandstone with biotite, and the Traverse outcrop (6 ppm $\mathrm{U})$, a coarse, white sandstone with mica. Elevated U readings were also recorded from 
intervals without significant heavy minerals, clay or mica, e.g., Jacobsville outcrop (6.6 ppm $\mathrm{U})$ in a very fine-grained white sandstone. In the absence of primary U-bearing minerals or clays, $\mathrm{U}$ likely occurs as a secondary mineralization emplaced by fluid flow.

Elemental analyses of 11 rock-chip samples from the Rice Lake core are presented. The highest $\mathrm{U}$ concentrations were reported in the R95 mud chip (7.8 ppm), R17 white sandstone with chlorite bands $(6.5 \mathrm{ppm})$ and R114 red siltstone $(6.1 \mathrm{ppm})$. Presence of red iron oxide in the sample did not appear to affect $U$ concentrations.

\subsection{DISCUSSION}

\subsubsection{Limitations and Assumptions}

Selection of some wells based on elevated gross alpha tests, elevated NURE results, and word of mouth, may have biased the sample collection for this study toward areas with elevated U. Because wells are uncased in the Jacobsville Sandstone, well water U concentrations represent a mixture of groundwater from numerous intervals. If relatively Urich strata have low permeability, these intervals would not contribute significant water to the well and the resulting water concentration of $U$ would be low. The oxidation-reduction potential of well water was measured using a flow cell to isolate the probe from the atmosphere, however, the measured redox of well water may not accurately reflect redox conditions of the aquifer as groundwater may mix with air in the borehole. Groundwater ages of some wells in this study area are near the older limit of the $\mathbf{C F C}$ dating method. Additionally, the apparent ages derived from the CFC-11, CFC-12 and CFC-113 were not always consistent. Similar inconsistencies in CFC dating were reported in other studies. Bockgard et al. (2004) investigated the accuracies of CFC dating in crystalline bedrock and found that apparent recharge years calculated from CFC-11 were earlier than those calculated from CFC-12. Fractured bedrock results in mixing of groundwater with different ages. In addition, degradation of CFC may take place, particularly under reducing conditions.

\subsubsection{Comparison to Other Groundwater Studies}

The results of this study are consistent with the assessment by Kinze (2002) that areas with high redox and elevated $U$ in the rock are more prone to elevated $U$ in the groundwater, at least on a formation or basin scale. The occurrence of $U$ above the MCL in aquifers of the Jacobsville Sandstone is likely related to U-enrichment in the formation. Furthermore, these results agree with Szabo (1997), who found that some wells penetrating anomalously radioactive strata did not produce water with elevated radioactivity, e.g., a well penetrating a reducing mudstone with elevated $U$ did not produce water with elevated $U$. In this study, it appeared that the effects of elevated $\mathrm{U}$ in the sandstone could be moderated by other factors, resulting in moderate groundwater U concentrations below the MCL. Due to the red-bed characteristic of the Jacobsville Sandstone it is not likely to have reduced beds, so other factors, e.g., permeability of strata or groundwater residence time are likely to be important. Szabo (1997) also concluded that the presence of radioactive strata was required to produce elevated radioactivity in groundwater in the Newark Basin. This study found that wells that produce water with elevated $U$ do not necessarily have elevated $U$ in the 
surrounding rock, though groundwater may have encountered U-rich strata along its flow path.

Ivanovich (1991) showed that ${ }^{234} \mathrm{U} /{ }^{238} \mathrm{U}$ activity ratios increase asymptotically along flow paths in shallow oxidized aquifers and jump to high values at redox fronts, where low $\mathrm{U}$ solubility results in precipitation of $U$ on the aquifer grains which, in turn, enhances alpha recoil derived ${ }^{234} \mathrm{U}$. Where redox fronts are absent, such as in this study area, another mechanism is needed to explain high ${ }^{234} \mathrm{U} /{ }^{238} \mathrm{U}$ activity ratios. Tricca (2000) showed that high ${ }^{234} \mathrm{U} /{ }^{238} \mathrm{U}$ activity ratios could also be achieved through low weathering rates. Dabous and Osmond (2001) showed that groundwater with high U concentration frequently has low activity ratios because alpha-recoil derived ${ }^{234} \mathrm{U}$ is relatively less important under strong dissolution. This relationship was observed in the Houghton-Chassell area where wells with high groundwater $\mathrm{U}$ concentrations have low ${ }^{234} \mathrm{U} /{ }^{238} \mathrm{U}$ activity ratios. Tricca (2000) showed that groundwater with both high $\mathrm{U}$ concentrations and high ${ }^{234} \mathrm{U} /{ }^{238} \mathrm{U}$ activity ratios may indicate an influence of the vadose zone or low weathering rates combined with long flow distances or low water velocities. Some wells, e.g., near the Keweenaw Bay Community and east of Skanee, have both high groundwater $U$ concentrations and high ${ }^{234} \mathrm{U} /{ }^{238} \mathrm{U}$ activity ratios. Porcelli and Swartzenski (2003) explained that changes in U host phase or geochemistry influence weathering without influencing recoil, which results in a change in the activity ratio. Thus, variations in ${ }^{234} \mathrm{U} /{ }^{238} \mathrm{U}$ in this study area may indicate differences in $\mathrm{U}$ host phase, travel times, and/or influence from the vadose zone.

Osmond and Cowart (1992) developed plots of ${ }^{234} \mathrm{U} /{ }^{238} \mathrm{U}$ versus the reciprocal of $\mathrm{U}$ concentration and interpreted straight-line trends as evidence of mixing or dilution of different groundwater. The Houghton-Chassell wells in this study area plotted in a linear array extending from the lower left corner to the upper right corner, which may be interpreted as a mixing of groundwater with low $\mathrm{U}$ concentration and a high activity ratio with groundwater with recently leached $U$ and a low activity ratio. Though not common, very high ${ }^{234} \mathrm{U} /{ }^{238} \mathrm{U}$ activity ratios occurred in our study area. This is consistent with finding by Osmond and Cowart (1992) that activity ratios of 5, 10, and even 20 or higher have been measured in steady long-term flow systems of large confined aquifers.

\subsubsection{Association of Uranium with Shale}

The Western UP Health Department (2001) hypothesized that U in the Jacobsville Sandstone was associated with interbedded shale layers in the formation. Uranium is relatively insoluble in its reduced (IV) state and accumulates in reducing environments. In carbonates, $\mathrm{U}$ is associated with interbedded marine shales deposited in low oxidation environments. Szabo (1997) found that elevated U concentrations in rocks of the Newark Basin were associated with reducing shales. Bristow and Myers (1989) found that siltstones and mudstones had a 10\%-20\% increase in Th and $\mathrm{U}$ over sandstones in Namurian deltaic succession. Cuttell et al. (1988) studied U-series isotopes in UK groundwater in the PermoTriassic clay-containing (primarily illite) red sandstone with occasional, usually thin, mudstones. The authors claimed there was generally no stratigraphic correlation of $U$ and Th, although the fine-grained beds contained higher concentrations. Kim (1999) investigated $\mathrm{U}$ in Paleozoic aquifers in the Llano Uplift area of central Texas and concluded that $\mathrm{U}$ was most likely to be found in groundwater flowing through intervals of high concentrations of shale laminae, phosphatic material, or Fe-oxide cements. Black shales may 
have significant $\mathrm{U}$ enrichment (1250 ppm), but gray-green and yellow-red shales do not have much higher $U$ than sandstones (Gascoyne 1992), which may explain why the outcrops in the red-bed Jacobsville Sandstone do not show as stronger correlation between $U$ and the interbedded shales and siltstones.

\subsubsection{Secondary Uranium Minerals more Soluble than Primary Uranium Minerals}

Durance (1984) studied the New Red Sandstone in south-east Devon and found that sedimentary rock sequences with primary, detrital, U-bearing minerals required long residence times to increase the $\mathrm{U}$ content of young groundwater to appreciable levels. In southeast Devon, rocks had 4 ppm U but the young (as determined by tritium) groundwater had less than $1 \mathrm{ppb} \mathrm{U}$. Conversely, rocks with secondary $\mathrm{U}$ may rapidly result in groundwater $\mathrm{U}$ concentrations up to $30 \mathrm{ppb}$. However, unless the groundwater can be successfully dated, or secondary minerals observed, it is impossible to resolve the interaction of residence time and availability for dissolution.

\subsubsection{Other facies relationships of $\mathrm{U}, \mathrm{K}$ and $\mathrm{Th}$}

Bristow and Myers (1989) found a concentration of Th-bearing minerals associated with the basal erosional surface of a major braided fluvial distributary channel and mouth-bar deposits where heavy mineral were concentrated up to $31.6 \mathrm{ppm}$. The Pequaming Alternating outcrop showed high Th associated with overbank deposits. However, the L'Anse Main Channel outcrop did not show high Th. Bristow and Myers (1989) determined a positive correlation between Th and $\mathrm{K}(\mathrm{r}=0.58)$, which agrees with our measurements from the Jacobsville Sandstone. Bristow and Myers (1989) showed that lenses of fine-grained sandstone and siltstones and clays that marked the abandonment of one distributary in favor of another tended to be relatively radioactive with highest readings of $\mathrm{K}, \mathrm{U}$ and Th. This agrees with high $\mathrm{U}$ readings at the Grand Island Channel/Abandonment outcrop.

\subsubsection{Mineralogy associated with $U$, $K$ and $T h$}

Davies and Elliot (1996) showed that K was associated with K-feldspars, micas, illitic clays, while Th was concentrated in sand- and silt-sized heavy minerals, e.g., monazite and zircon groups, or in the fine-grained fraction, in association with select clay minerals and authigenic phosphates. Their observation that $\mathrm{U}$ was associated, in part, with heavy mineral suites is in agreement with findings from the Amoco core in this study.

Ehrenberg and Svana (2001) in their discussion of carbonates reported widespread appreciation that $\mathrm{K}$ and Th reflect classic content, whereas $\mathrm{U}$ is determined by diagenetic processes involving changes in oxidation state. Most of the published carbonate spectral gamma-ray studies ascribed localized $U$ enrichment to the movement of late diagenetic fluids, which may also be true for some areas of the Jacobsville Sandstone.

Davies and Elliot (1996) showed that terrestrial igneous rocks from which sediments are derived have $\mathrm{Th} / \mathrm{U}$ ratios of approximately 3.8. Sediments in oxidizing environments have higher Th/U ratios through loss of uranium in its soluble (VI) form. In contrast, the redbed Jacobsville Sandstone represents oxidizing sediments but has lower Th/U ratio than typical provenance rocks, indicating relative U enrichment. Ehrenberg and Svana (2001) 
considered the fraction of the bulk $U$ exceeding one-third of the Th content to be authigenic $\mathrm{U}$ and interpreted a $\mathrm{Th} / \mathrm{U}$ ratio of 0.41 to indicate most of the $\mathrm{U}$ was nondetrital in origin.

\section{CONCLUSIONS AND RECOMMENDATIONS FOR FUTURE WORK}

\subsection{CONCLUSIONS}

Distribution of $\mathrm{U}$ in well water:

- Approximately $25 \%$ of 270 wells analyzed in this study produced water with $U$ concentrations above the MCL. Approximately $7 \%$ of wells produced water with $\mathrm{U}$ concentrations over $100 \mu \mathrm{g} / \mathrm{L}$. The average well water $\mathrm{U}$ concentration was $25 \mu \mathrm{g} / \mathrm{L}$ and the median was $8 \mu \mathrm{g} / \mathrm{L}$.

- Elevated U was associated with bedrock rather than surficial wells.

- Well water U concentrations were generally consistent over time.

- Uranium concentrations above the MCL frequently occurred in clusters and neighboring wells tended to have similar $U$ concentrations except where topography resulted in significant differences in well bottom elevations.

- Groundwater age may help explain trends in groundwater U concentrations.

U isotopes:

- ${ }^{235} \mathrm{U} /{ }^{238} \mathrm{U}$ ratios were consistent with naturally occurring $\mathrm{U}$.

- ${ }^{234} \mathrm{U} /{ }^{238} \mathrm{U}$ activity ratios varied from near secular equilibrium to 16 with an average of 2.25 .

- In general, wells with elevated $\mathrm{U}$ concentrations had lower ${ }^{234} \mathrm{U} /{ }^{238} \mathrm{U}$ activity ratios. However, in some areas $U$ concentrations and ${ }^{234} \mathrm{U} /{ }^{238} \mathrm{U}$ activity ratios were simultaneously high, possibly indicating differences in rock-water interactions.

- In areas with high-density data, neighboring wells plotted in clusters and arrays on charts of ${ }^{234} \mathrm{U} /{ }^{238} \mathrm{U}$ versus the reciprocal of $U$ concentration, which highlights the potential for using $\mathrm{U}$ isotope data to trace groundwater from different aquifer conditions

Geochemical controls on U solubility:

- Well water had high redox, indicating $\mathrm{U}$ is in its highly soluble $\mathrm{U}(\mathrm{VI})$ valence.

- Negatively charged U carbonate complexes may limit U sorption to the iron oxides coating the aquifer grains.

- Uranium is generally undersaturated with respect to common U minerals. In some wells, high vanadium $(\mathrm{V})$ may limit $U$ solubility through precipitation of uranyl vanadates, though at concentrations above the MCL.

Correlation between well water $\mathrm{U}$ and host rock $\mathrm{U}$ concentrations:

- Low levels of U-enrichment in the Jacobsville Sandstone may make wells in its aquifers at risk for $\mathrm{U}$ concentrations above the MCL.

- However, the $U$ concentration of the host rock by itself is not enough to predict if a well will produce $\mathrm{U}$ above the MCL, indicating that other hydrogeochemical factors may modify the effects of $U$ enrichment in the sandstone.

- Uranium enrichment associated with Th may be due to heavy mineral or shale layers and may be relatively insoluble.

- Wells with greater $\mathrm{U}$ enrichment relative to Th and $\mathrm{K}$ do not necessarily produce water with higher $\mathrm{U}$ concentrations. 
- Correlation of curves between neighboring wells indicates relatively $U$ rich strata in some areas may be laterally continuous over hundreds of feet.

Distribution of $U$ in the sandstone:

- On average $U$ concentrations were highest in heavy mineral and clay layers and ripup conglomerates.

- U concentrations above 4 ppm also occurred in siltstones, sandstones and conglomerates.

- U enrichment was likely controlled by deposition processes, sorption to clays, and groundwater flow, which was controlled by permeability variations in the sandstone.

- Low levels of $U$ enrichment were found at deltaic, lacustrine and alluvial fan deposits and were not isolated to specific depositional environments.

- Outcrops with alternating white sandstone and red silt facies did not show a strong association of $U$ with the finer grained facies.

- Th/U ratios in the Jacobsville Sandstone are lower than Th/U ratios of typical provenance rocks suggesting secondary U-enrichment by fluid flow.

- Clay type (\% illite) of the fine-grained fraction of the Jacobsville sandstone does not control total or partial U concentrations.

\subsection{RECOMMENDATIONS FOR FUTURE WORK}

Additional characterization of wells and interval sampling was proposed (but not funded) for this study. Wells are uncased in the Jacobsville Sandstone and well water U concentrations represent a mixture of groundwater from numerous intervals. Packers could be utilized to isolate relatively U-rich intervals, e.g., the $22 \mathrm{ppm} \mathrm{U}$ interval in the PLAKE2 well, to determine if relatively $\mathrm{U}$-rich strata produce groundwater with relatively high $\mathrm{U}$ concentrations. Alternatively, well water $U$ concentrations may reflect a variety of host-rock $\mathrm{U}$ concentration along a flow path and may not correlate with specific rock $\mathrm{U}$ concentrations in the vicinity of the borehole. It would be valuable to determine which intervals in the borehole produce the most water. If relatively U-rich strata have low permeability, these intervals may not contribute significant water, or $\mathrm{U}$, to the well. Downhole video could be used to determine if U-rich intervals are fractured, which would increase production from these intervals. Drilling a core in an area with elevated groundwater U, though relatively expensive, would allow for a direct identification of the lithology and mineralogy associated with the elevated groundwater U. Gamma-ray spectroscopy on the core could be conducted to obtain $\mathrm{U}$, Th and $\mathrm{K}$ data, and determine how the curve signature related to the lithology and mineralogy in the core. The mineralogy of the core could be analyzed in more detail quantify the amount of $\mathrm{U}_{-}$, Th- and K-bearing minerals for intervals of interest.

The oxidation-reduction potential (ORP) of well water was measured using a flow cell to isolate the probe from the atmosphere. However, the measured redox of well water may not accurately reflect redox conditions of the aquifer as groundwater may mix with air in the borehole. More sophisticated methods may be required to determine redox conditions of the aquifer.

Groundwater age dating of all logged wells, and other wells throughout the study area, would further elucidate the influence of groundwater residence time on groundwater $U$ concentrations. However, groundwater ages of some wells in this study area are at older limit of the CFC dating method. Additionally, the apparent ages derived from the CFC-11, 
CFC-12 and CFC-113 were not always consistent. ${ }^{3} \mathrm{H} /{ }^{3} \mathrm{He}$ groundwater dating is more expensive than CFC dating, similarly limited in range, and samples are more difficult to collect, however it may be more accurate.

The influence of vadose zone reactions on aquifer ${ }^{234} \mathrm{U} /{ }^{238} \mathrm{U}$ activity ratios could be investigated by collecting $U$ isotope samples from the vadose zone. 


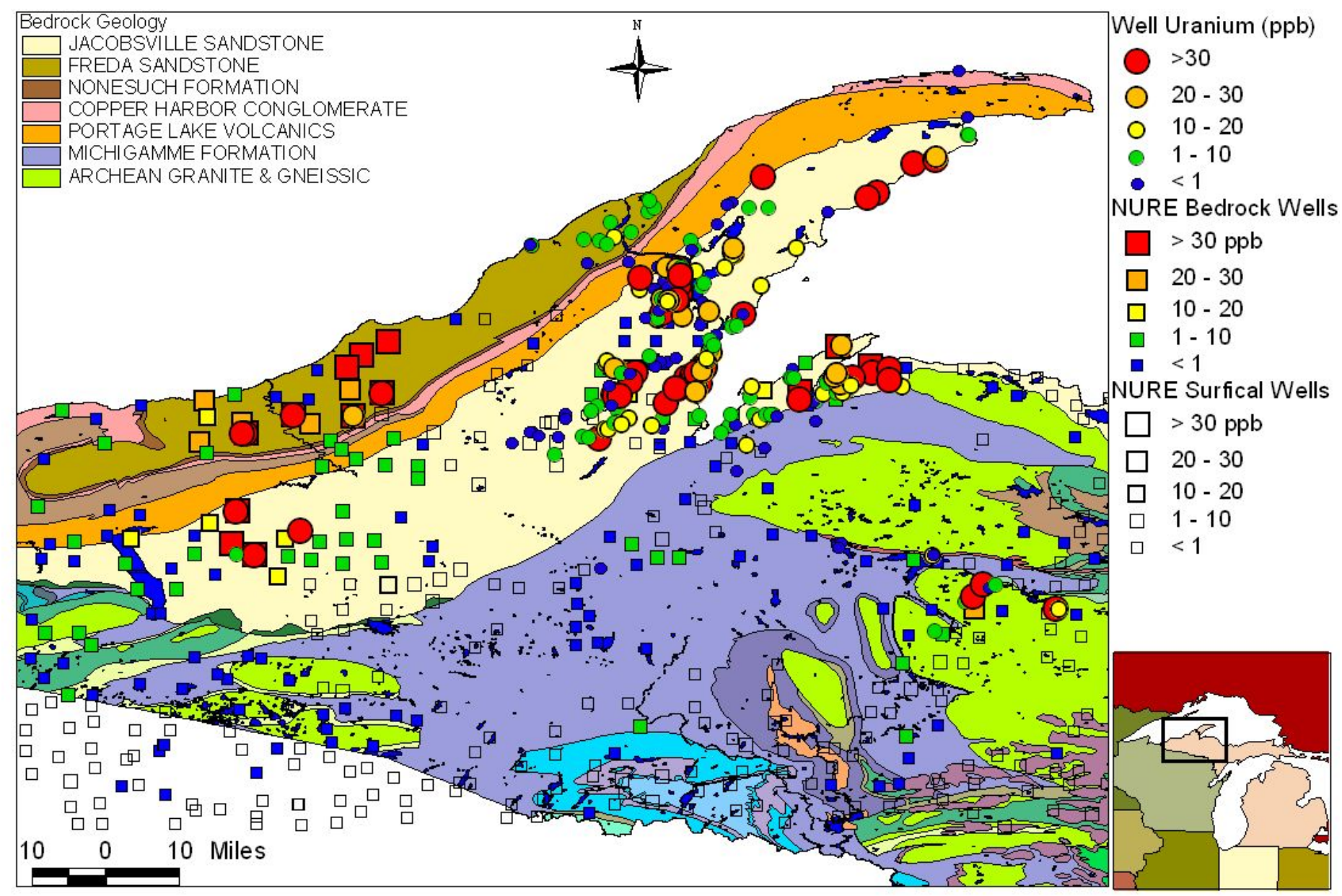

Figure 1 Distribution of $U$ in well water in relation to bedrock geology. Wells in this study (circles) and National Uranium Resource Evaluation (NURE) wells (squares) with U>MCL are shown in red. Surficial wells (open squares) have low U concentrations. 


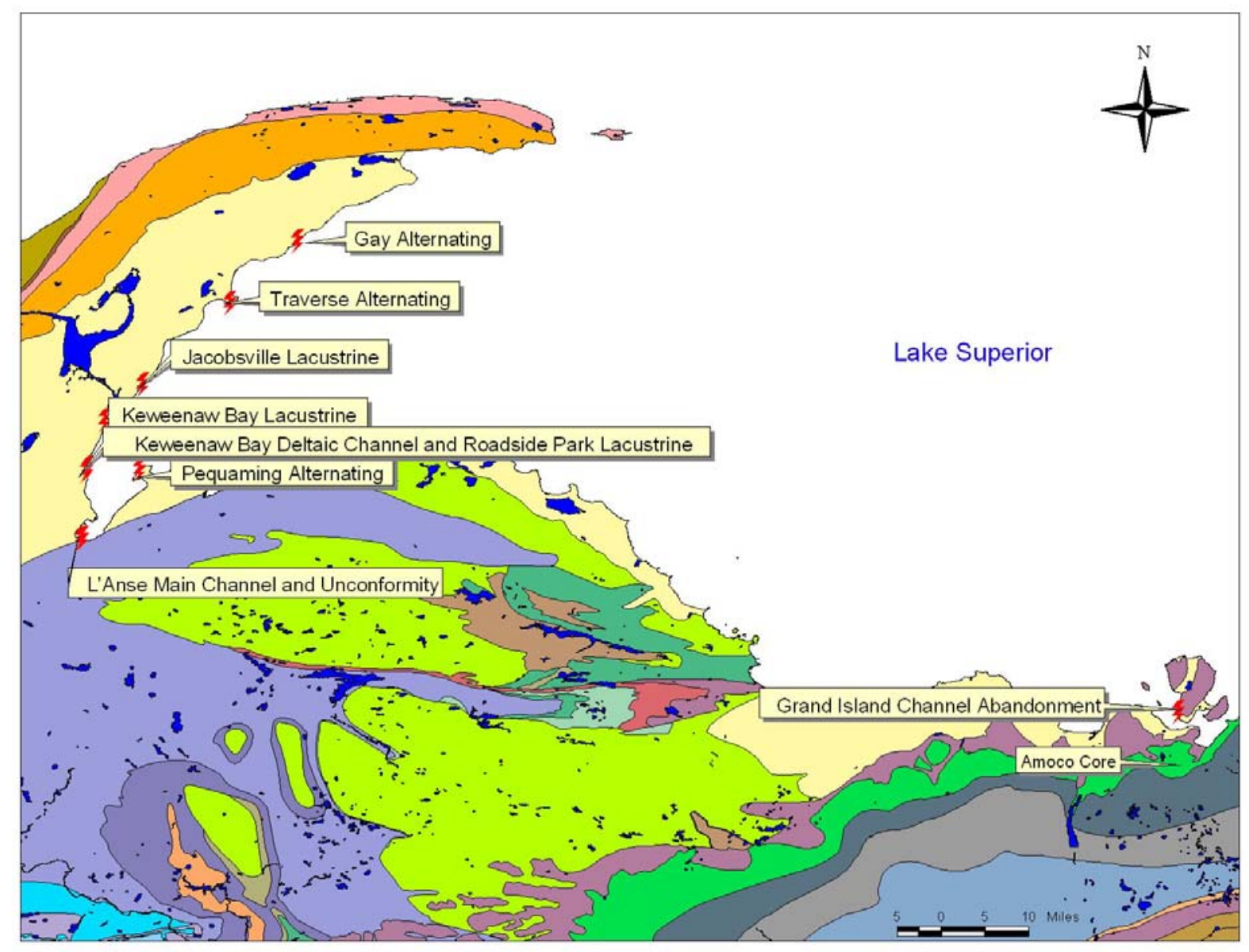

Figure 2 Location of outcrops logged with a gamma-ray spectrometer. Outcrops represent a variety of lithologic and depositional facies. 


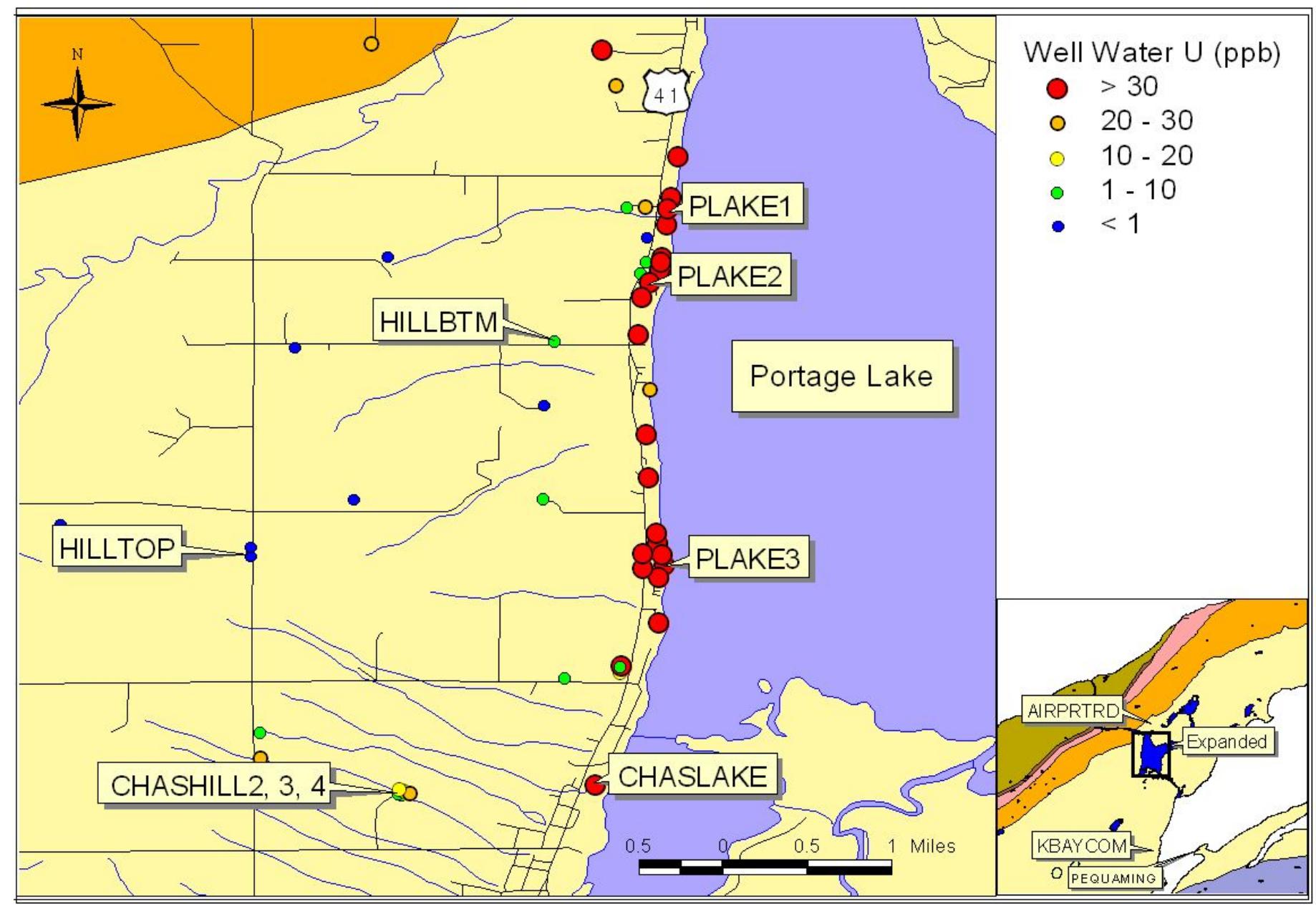

Figure 3 Location of wells logged with a gamma-ray spectrometer. The wells represent a range of groundwater U concentrations. A linear anomaly of elevated U occurs in wells along Portage Lake, and appears to be related to elevation of well bottoms. 


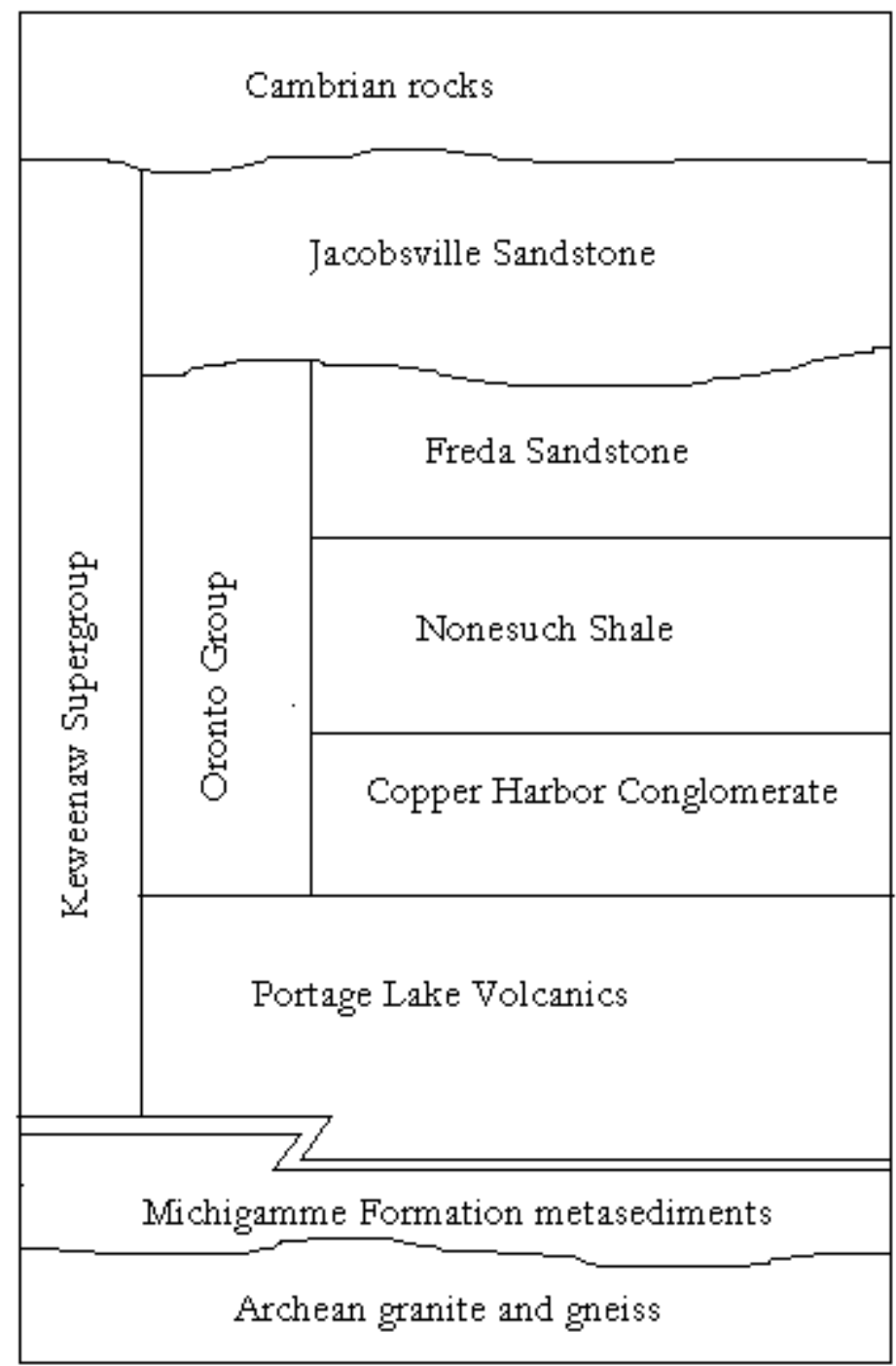

Figure 4 Stratigraphic column of relevant formation in the study area. 


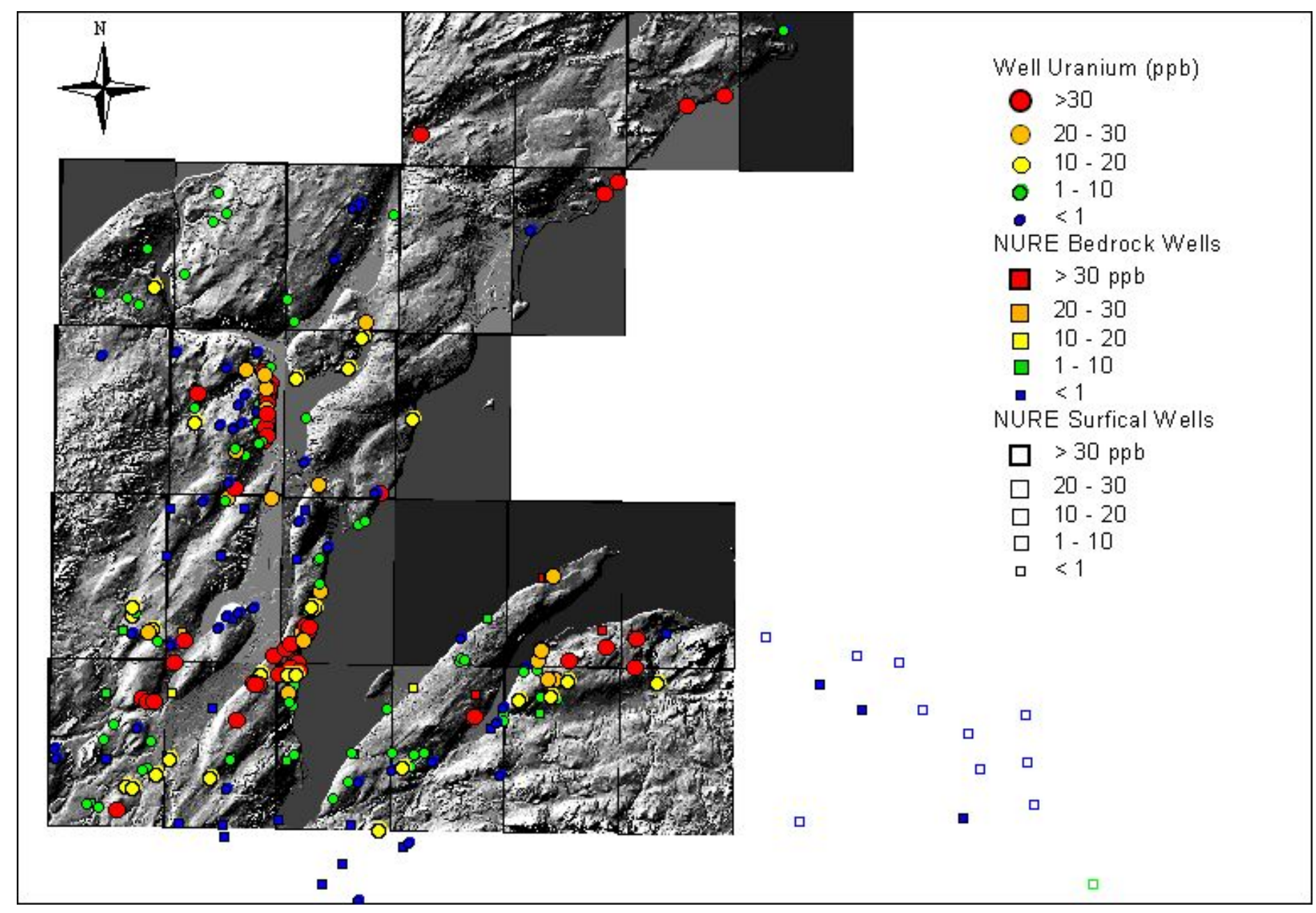

Figure 5 Distribution of $U$ in well water in relation to topography. In some areas $U$ concentrations appear to increase down slope, while in other areas $U$ concentrations are high near recharge areas. 


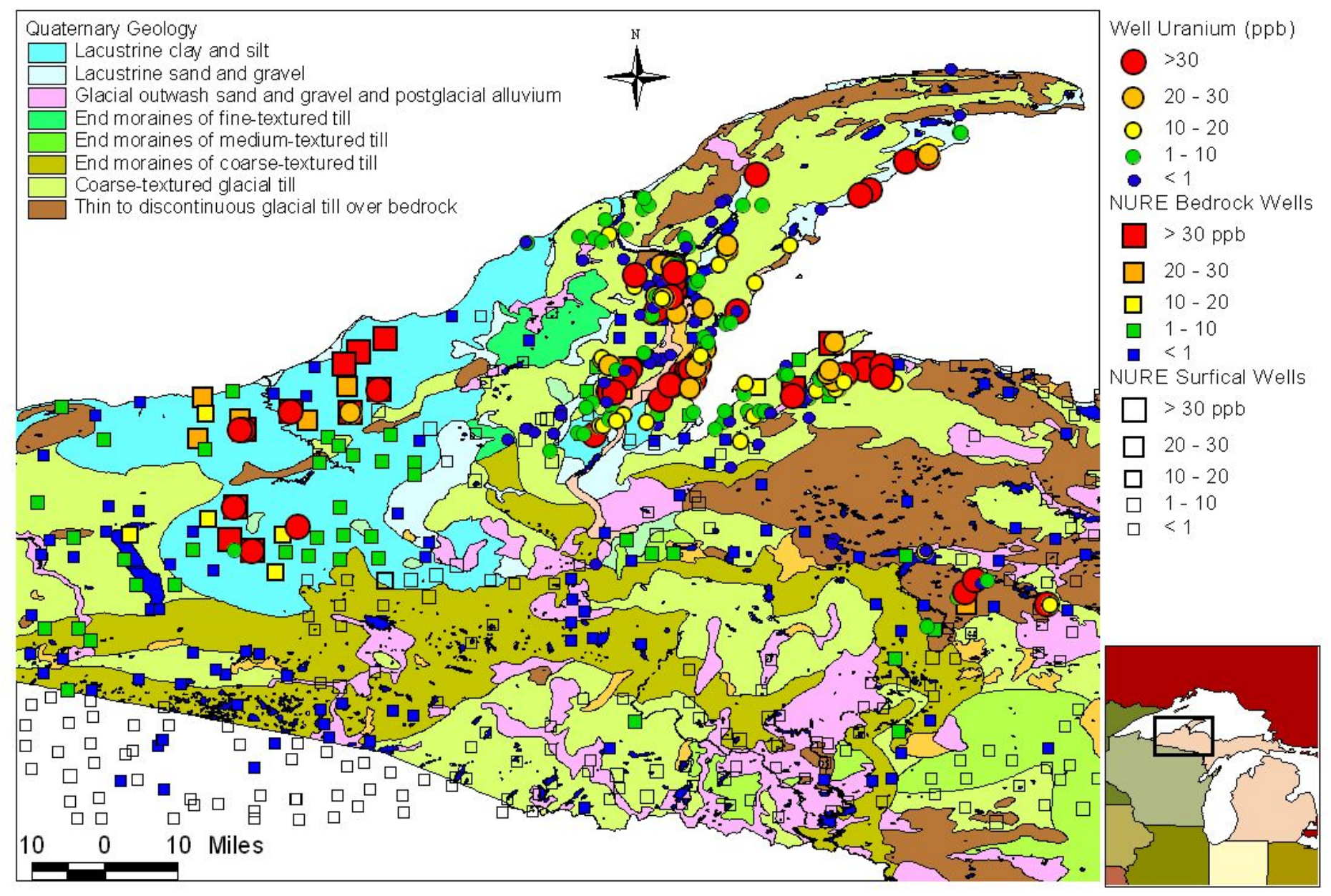

Figure 6 Distribution of $U$ in well water in relation to Quaternary geology. A large cluster of wells with elevated U occurs where bedrock is overlain by lacustrine clay and silt. Elevated U also occurs where the bedrock is overlain by lacustrine sand and gravel, and glacial till. 


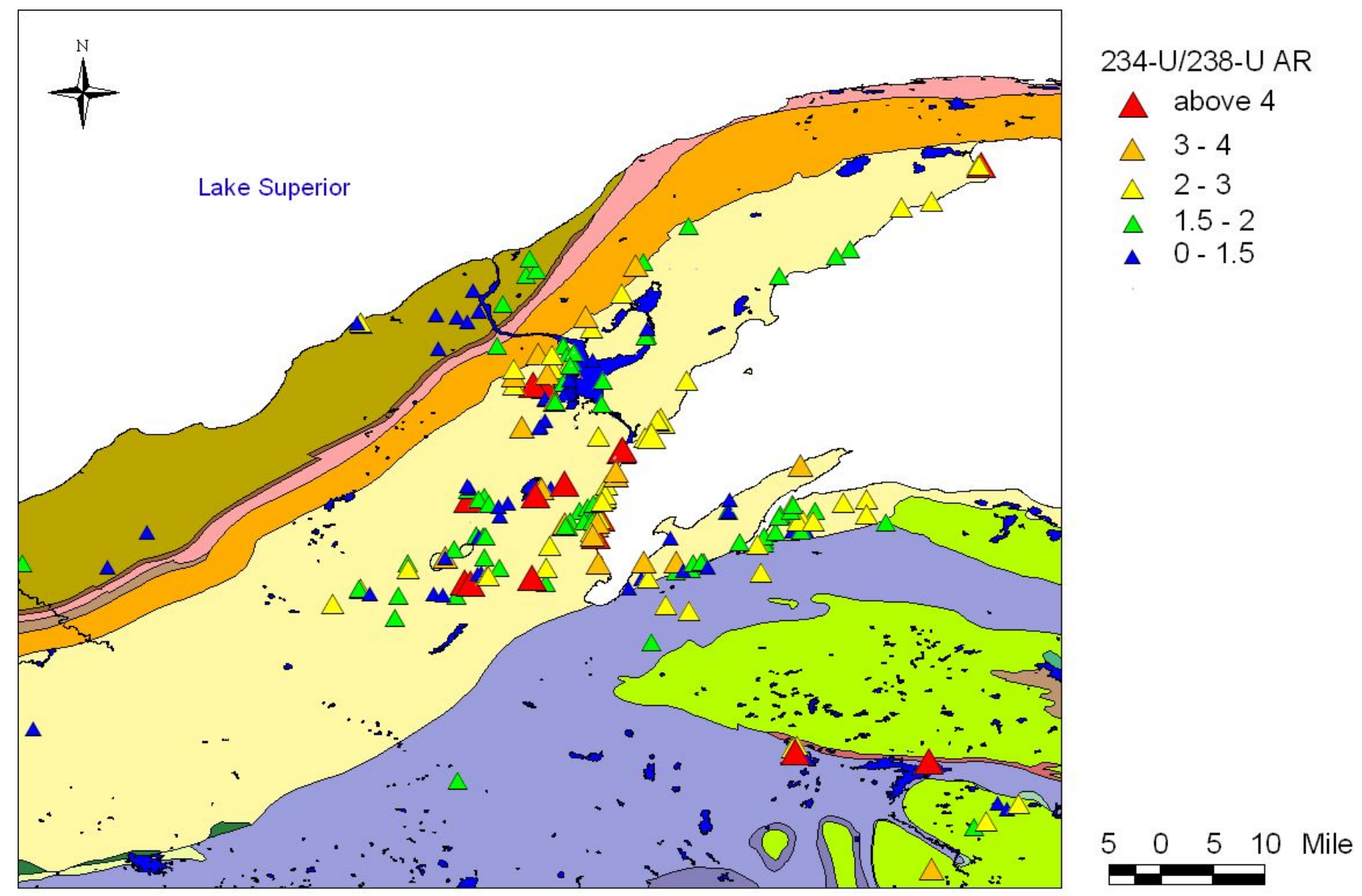

Figure 7 Distribution of ${ }^{234} \mathrm{U} /{ }^{238} \mathrm{U}$ activity ratios in well water. Neighboring wells frequently show similar activity ratios. 
Activity Ratio vs $1 / \mathrm{U}$ Trends for Select Regions

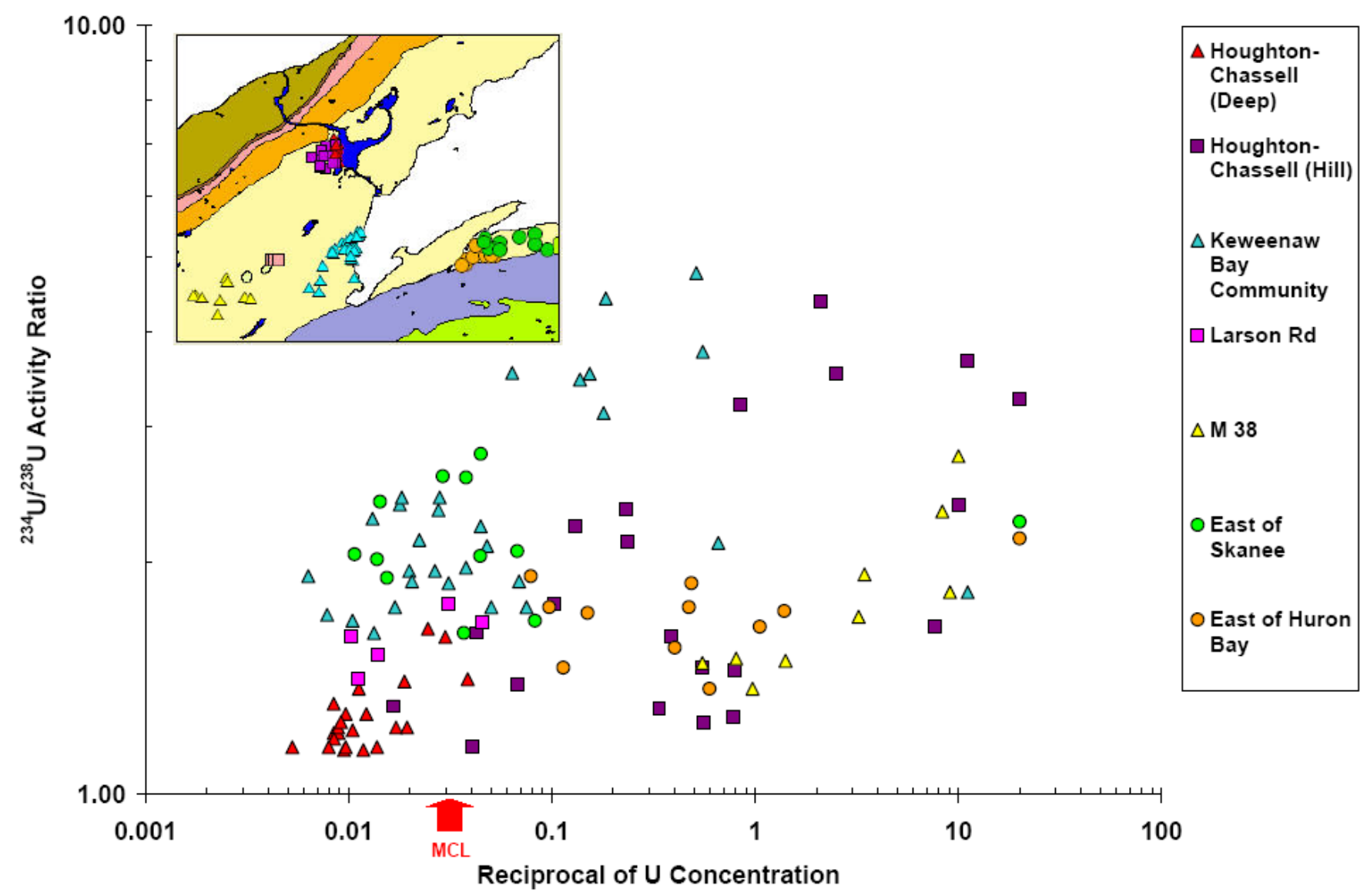

Figure $8{ }^{234} \mathrm{U} /{ }^{238} \mathrm{U}$ activity ratio versus reciprocal of $\mathrm{U}$ concentration. Wells are grouped spatially as shown on the inset. Neighboring wells plot in clusters that may overlap with wells from other regions that exhibit similar rock-water interactions. Horizontal trends (parallel to the $1 / \mathrm{U}$ axis) within a region are interpreted as varying degrees of $\mathrm{U}$ dilution. Trends from the lower left corner to upper right may be interpreted as mixing of high $\mathrm{U} /$ low AR water with low $\mathrm{U} /$ high AR water or progressive dissolution of the host rock $(\mathrm{AR}=1)$. 
Activity Ratios vs 1/U: Houghton-Chassell

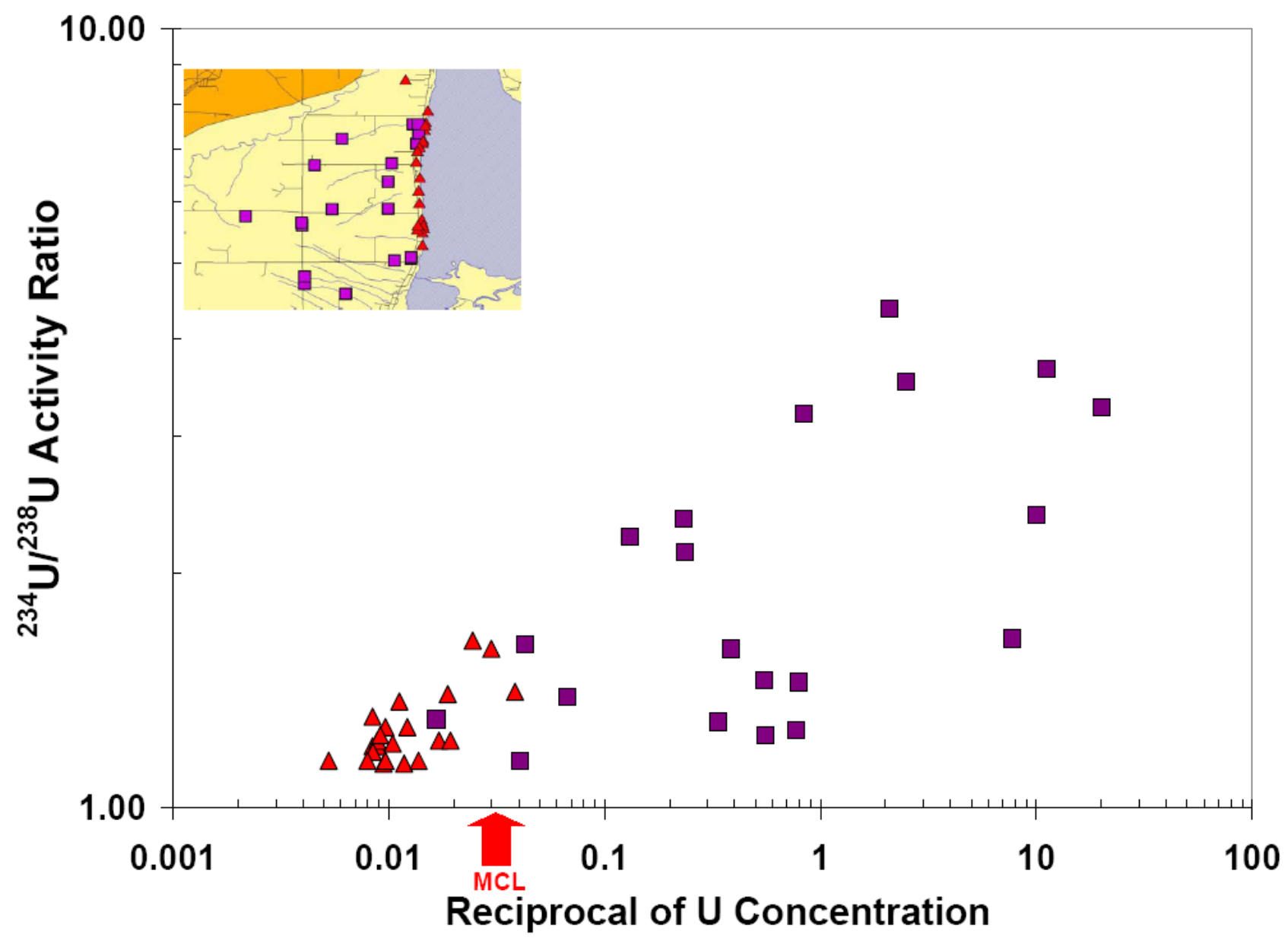

Figure $9{ }^{234} \mathrm{U} /{ }^{238} \mathrm{U}$ activity ratio versus reciprocal of $\mathrm{U}$ concentration in the Houghton-Chassell area. Wells are grouped spatially as shown on the inset. Wells with elevated $U$ concentrations tend to have lower activity ratios, perhaps due to strong dissolution of $U$ minerals, which would make the ${ }^{234} \mathrm{U}$ contributed by alpha recoil relatively less important. Elevated AR may indicate vadose zone influence. 


\section{Activity Ratio vs $1 / \mathrm{U}$ Trends for Select Moderate to High U Wells}

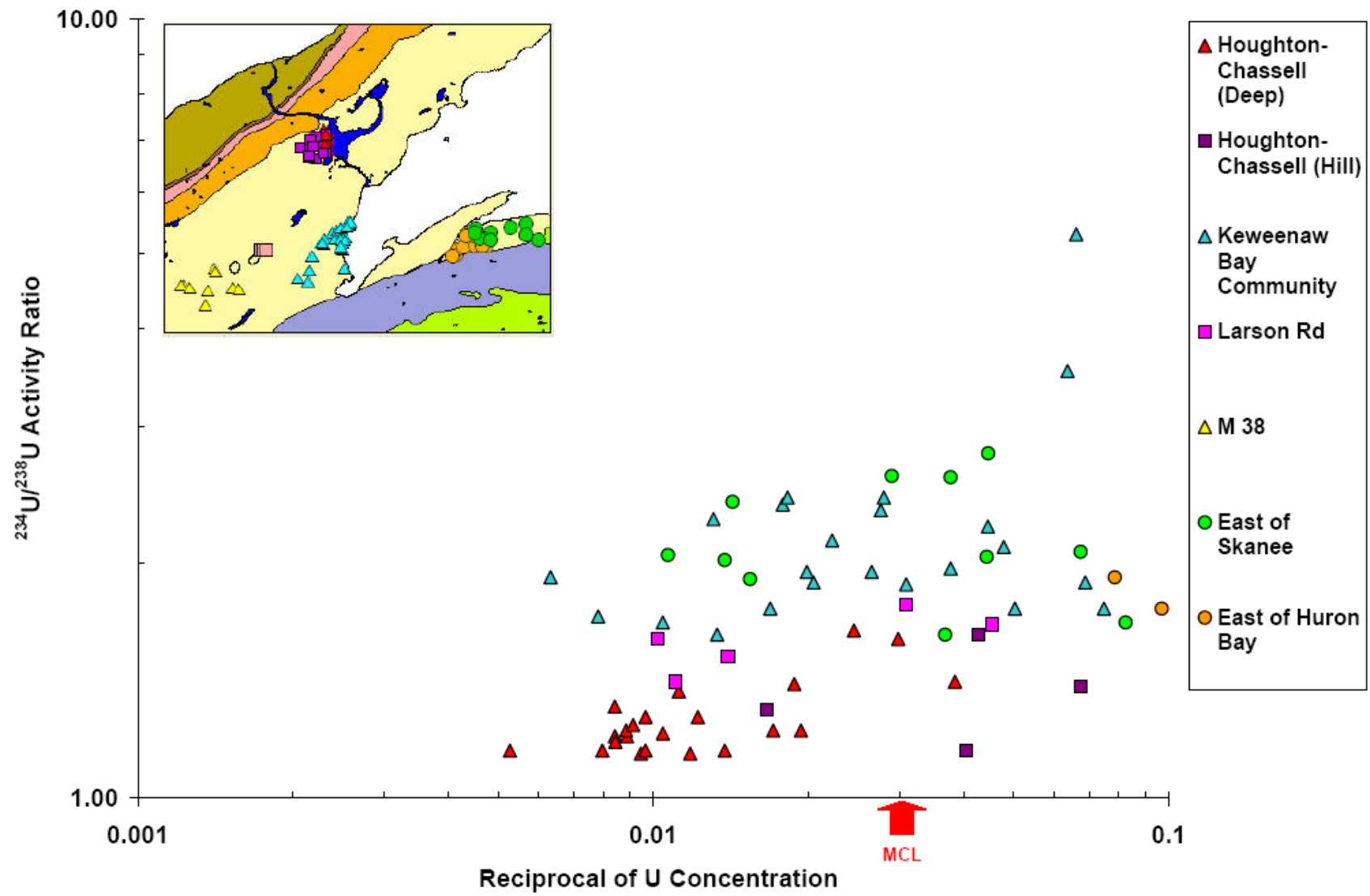

Figure $10{ }^{234} \mathrm{U} /{ }^{238} \mathrm{U}$ activity ratio versus reciprocal of $\mathrm{U}$ concentration for select moderate to high $\mathrm{U}$ wells. In contrast to the HoughtonChassell area, wells in the Keweenaw Bay Community area and east of Skanee show elevated activity ratios; perhaps do to long groundwater residence time. 


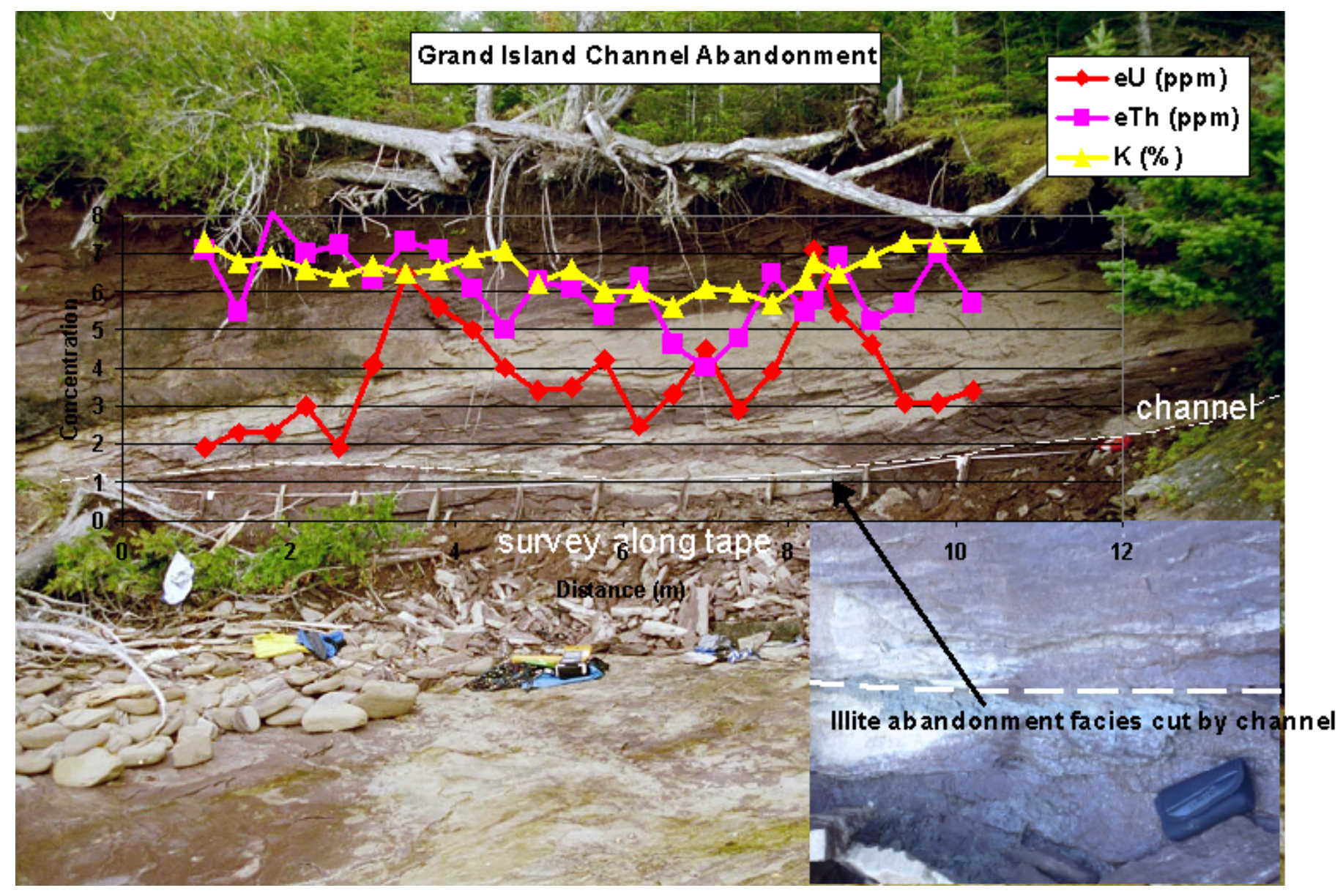

Figure $11 \mathrm{U}$, Th and K curves for the Grand Island Channel Abandonment outcrop. Groundwater flowing through the permeable channel structure may have resulted in low $\mathrm{U}$ enrichment in the clay abandonment facies. 


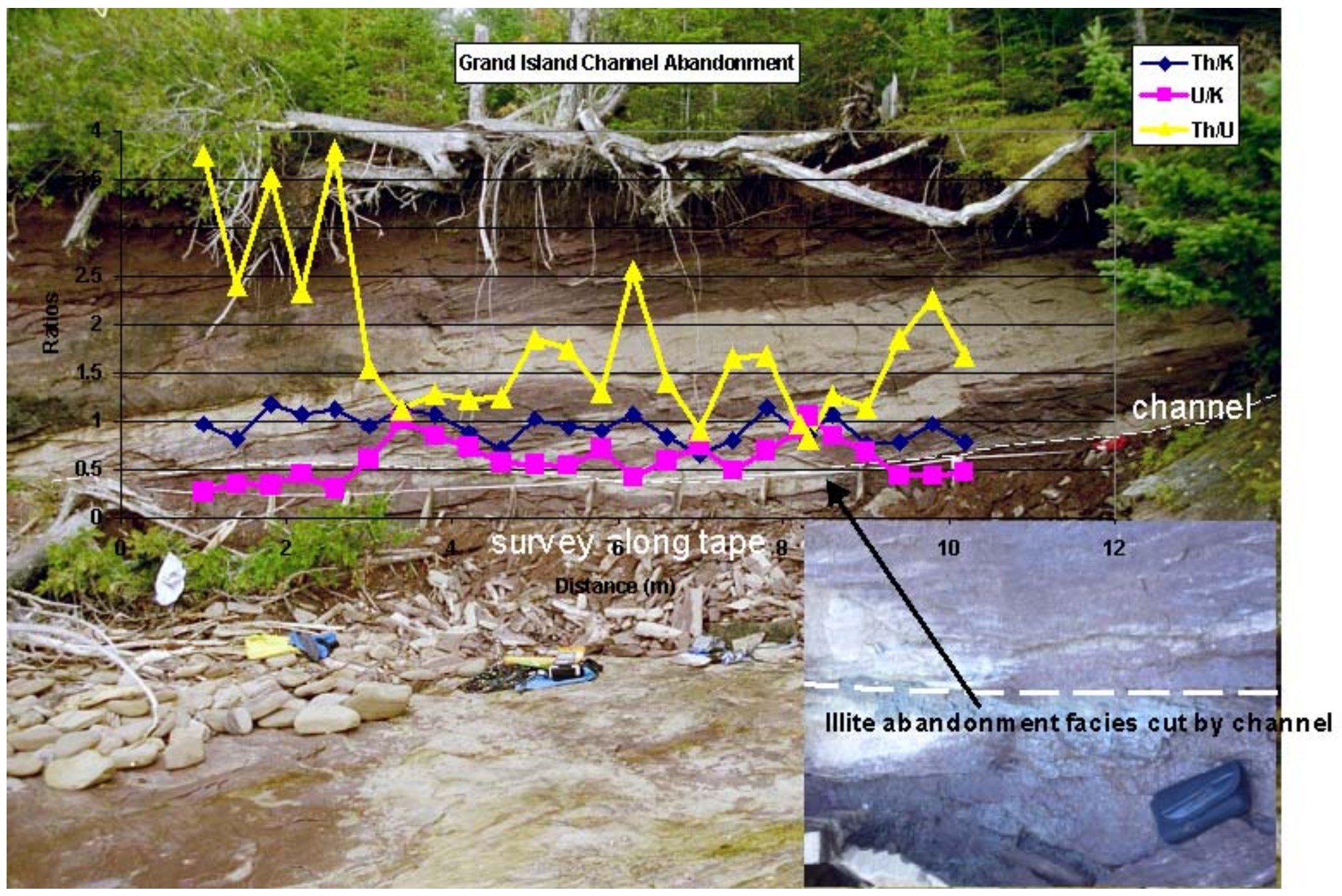

Figure $12 \mathrm{U}$, Th and $\mathrm{K}$ ratio curves for the Grand Island Channel Abandonment outcrop. Uranium enrichment relative to Th and $\mathrm{K}$ occurs at the illite abandonment facies. 


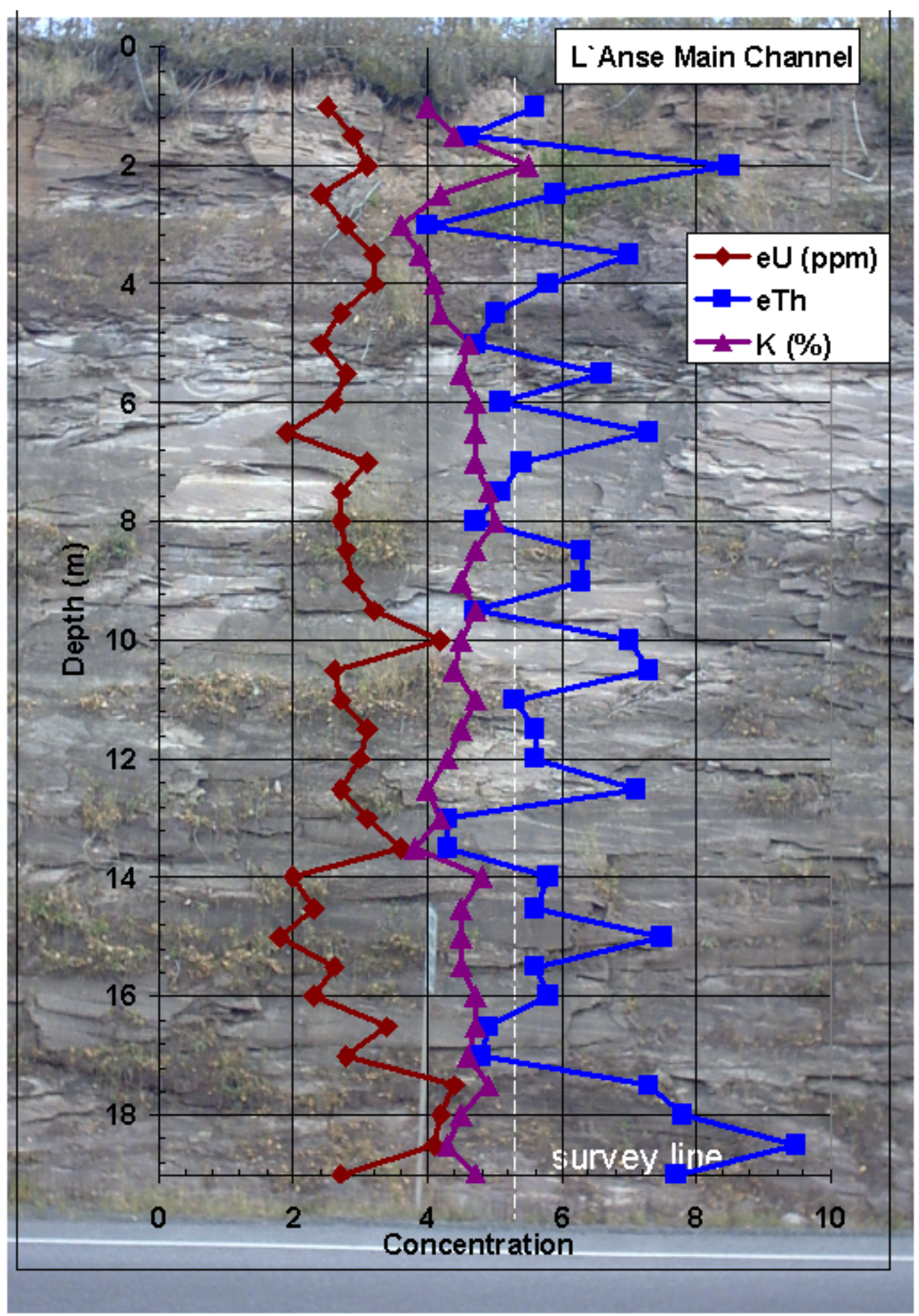

Figure $13 \mathrm{U}$, Th and K curves for the L'Anse Main Channel outcrop. This outcrop shows relatively low $\mathrm{U}$ compared to other outcrops. 


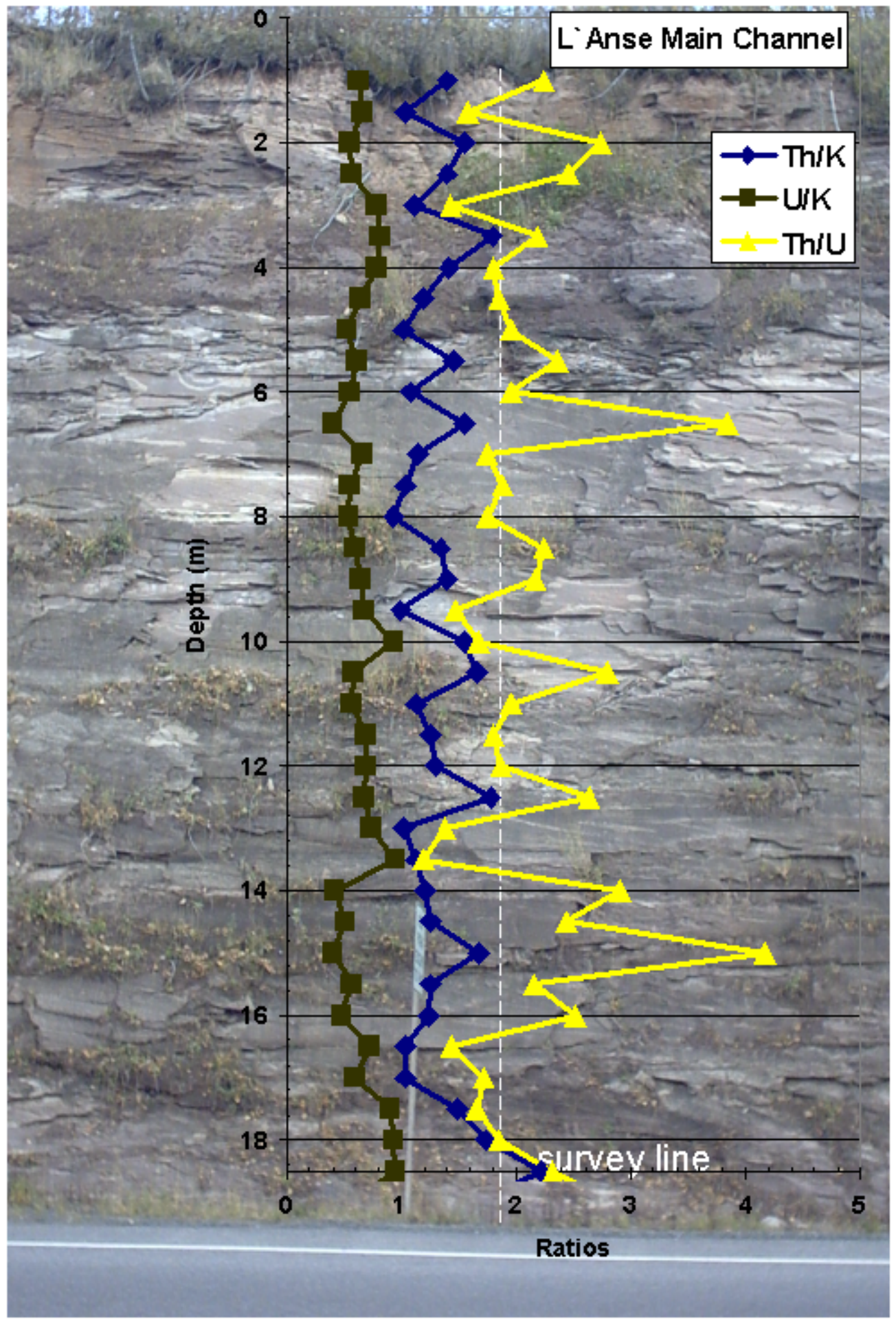

Figure $14 \mathrm{U}$, Th and $\mathrm{K}$ ratio curves for the L'Anse Main Channel outcrop. This outcrop does not show intervals of relative $\mathrm{U}$ enrichment. 


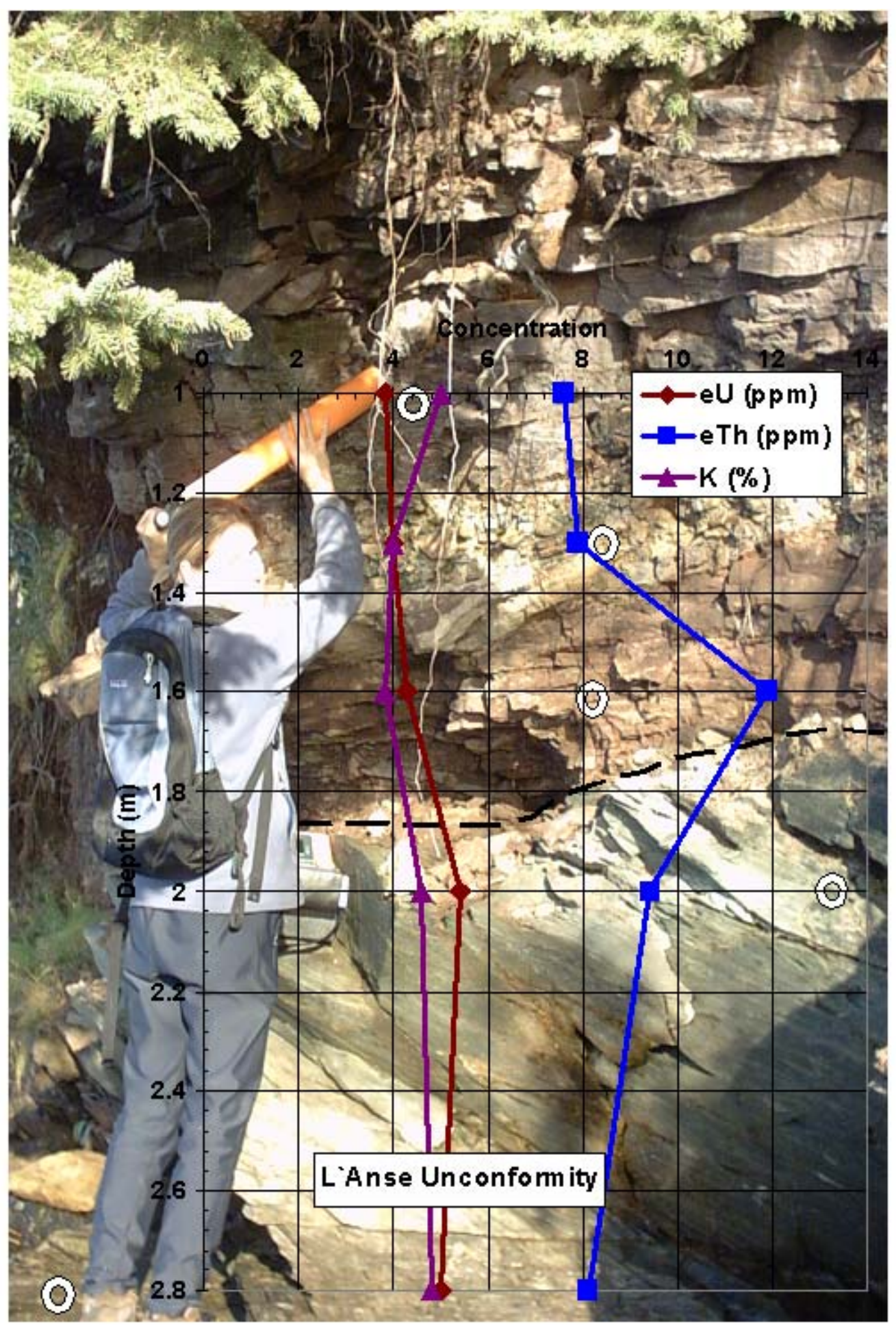

Figure $15 \mathrm{U}$, Th and $\mathrm{K}$ curves for the L'Anse Unconformity outcrop. Basal conglomerates occur in the Jacobsville Sandstone, underlain by slate. 


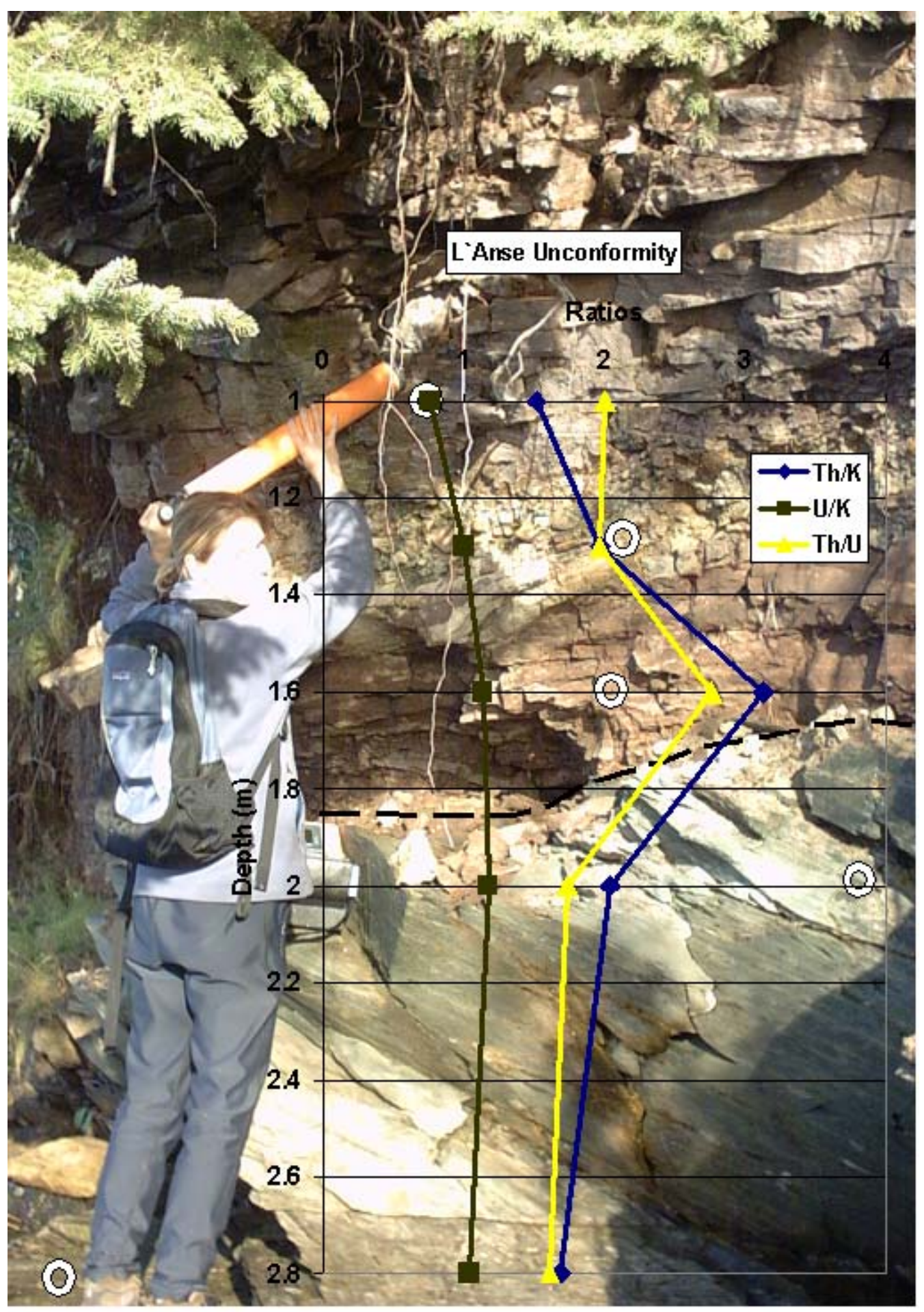

Figure $16 \mathrm{U}$, Th and $\mathrm{K}$ ratio curves for the L'Anse unconformity outcrop. This outcrop does not show intervals of relative $U$ enrichment. 


\section{Keweenaw Bay Deltaic Channel}

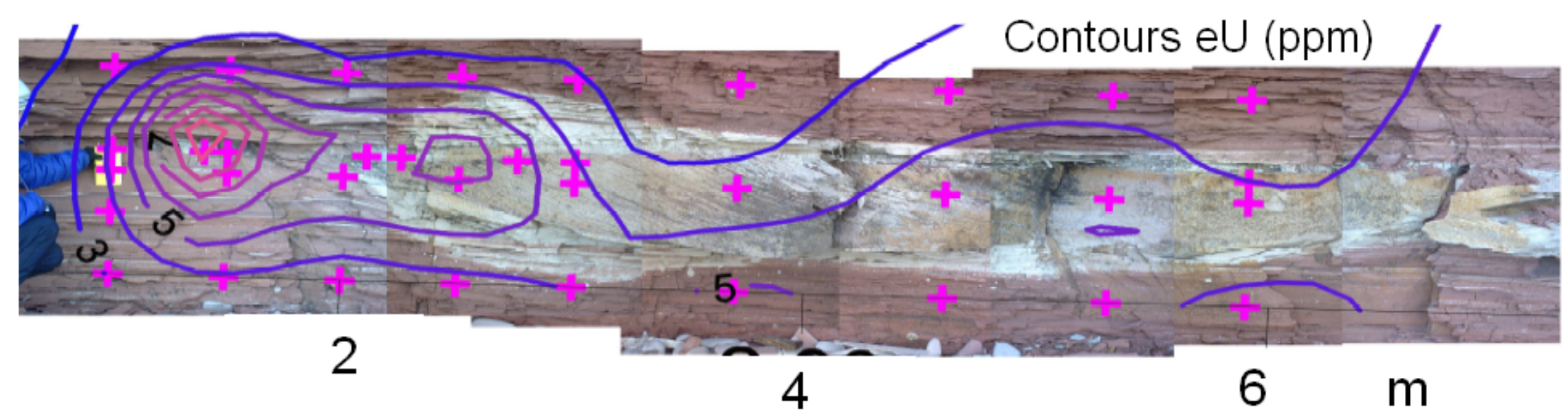

Figure $17 \mathrm{U}$ and at the Keweenaw Bay Deltaic Channel outcrop. Uranium enrichment up to 12 ppm is located near the edge of the permeable, leached channel structure, possibly emplaced by groundwater flow. Uranium is enriched relative to Th (not shown). 


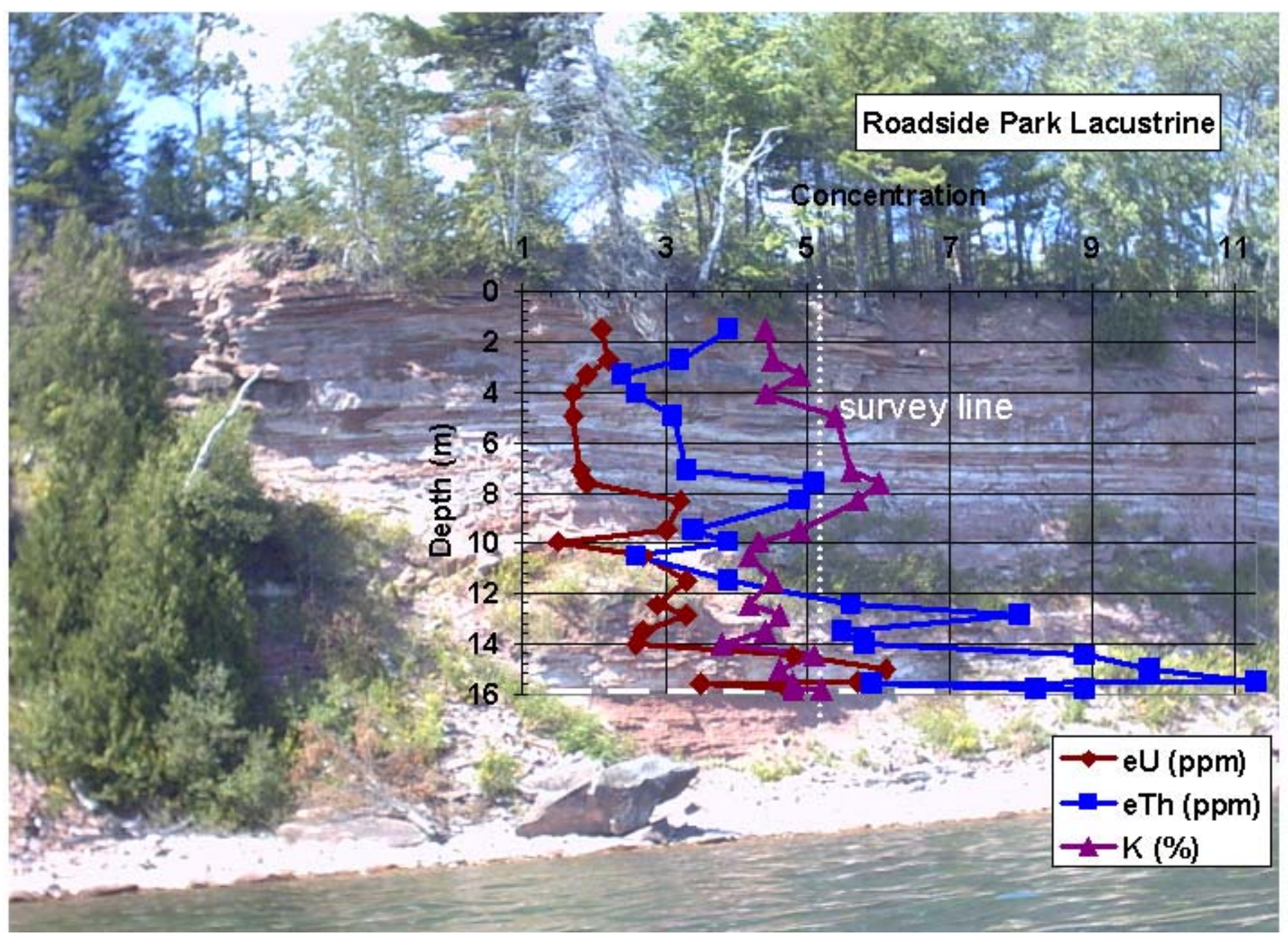

Figure $18 \mathrm{U}$, Th and K curves for the Roadside Park Lacustrine outcrop. Low U enrichment occurs near the base of the outcrop where lacustrine deposits overlay deltaic deposits. The well across the street has high $\mathrm{U}$, while a shallow hand pump has low U. 


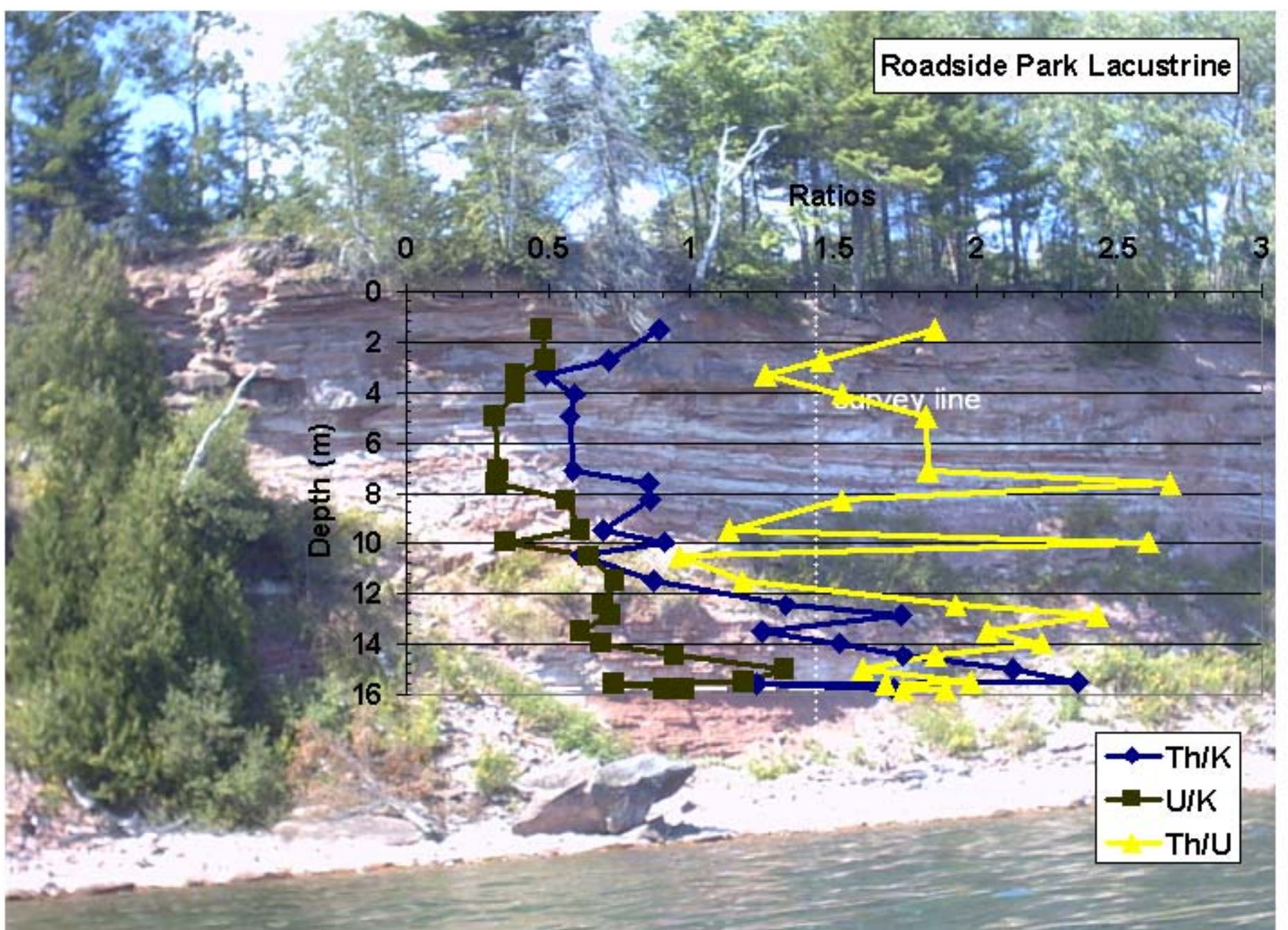

Figure $19 \mathrm{U}$, Th and $\mathrm{K}$ ratio curves for the Roadside Park Lacustrine outcrop. This outcrop does not show intervals of relative U enrichment. 


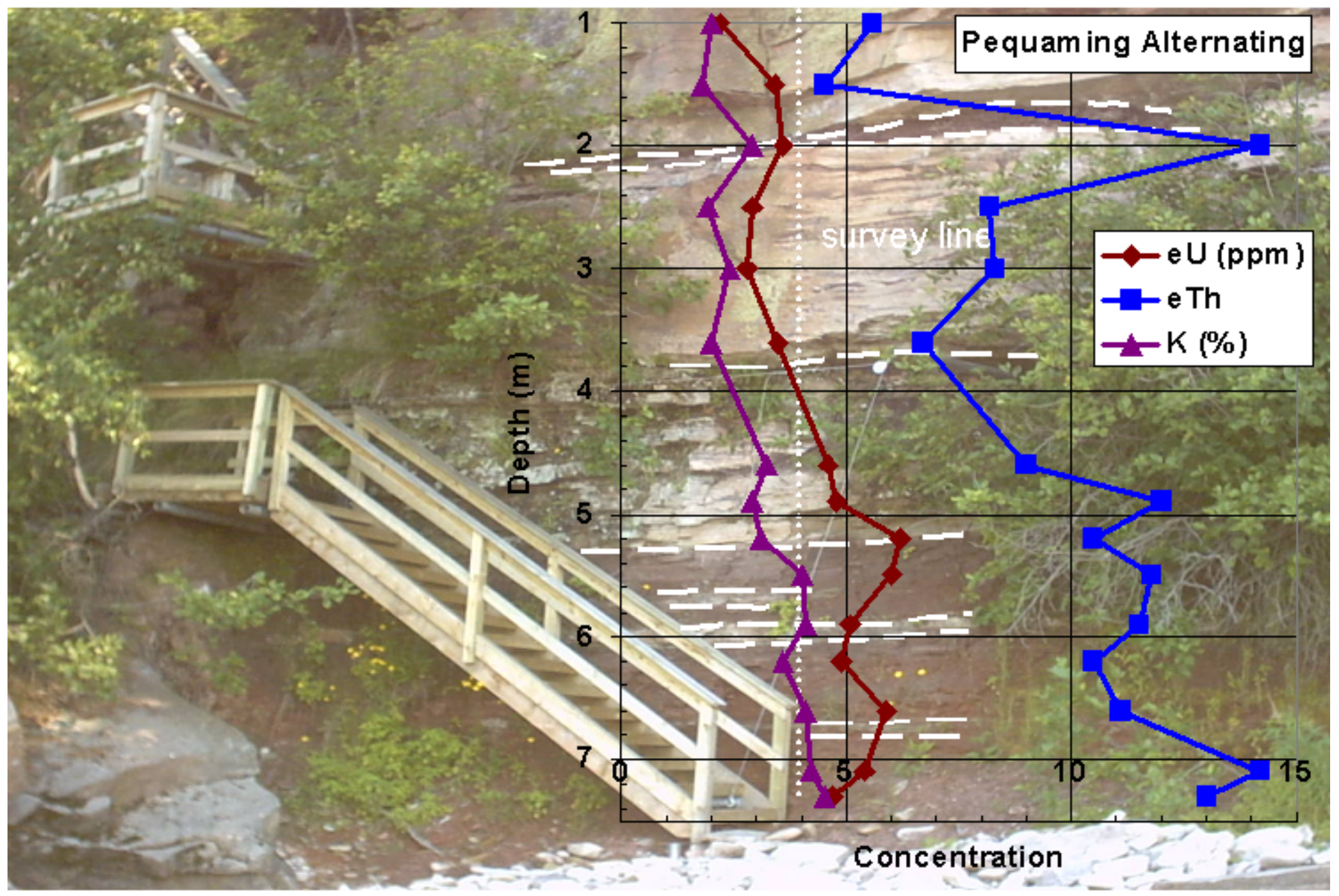

Figure $20 \mathrm{U}$, Th and $\mathrm{K}$ curves for the Pequaming Alternating outcrop. Uranium appears higher in the silty layers in the lower portion of the outcrop and the overlying rip up conglomerate. Note the high Th reading in the upper siltstone layer. 


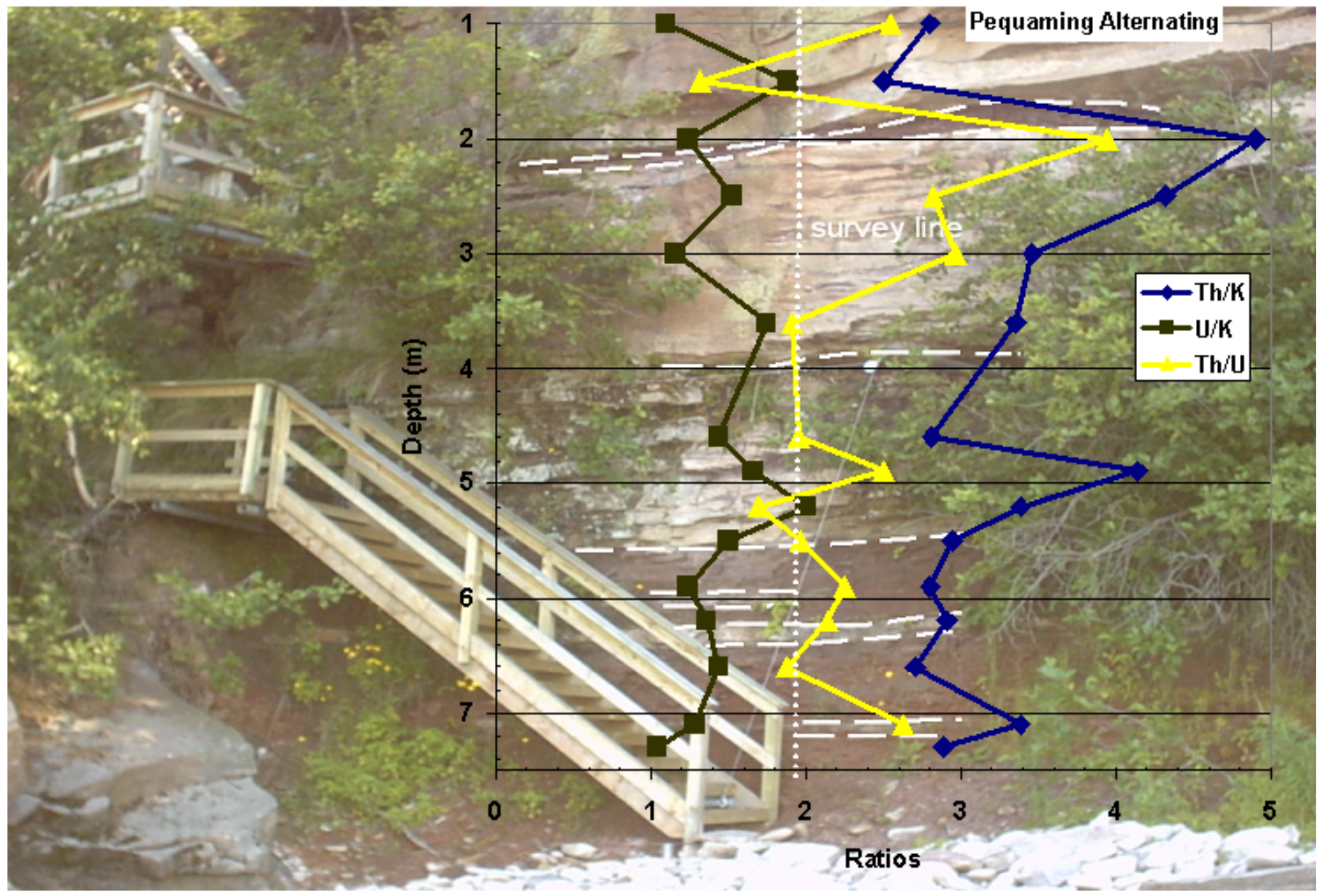

Figure $21 \mathrm{U}$, Th and K ratio curves for the Pequaming Alternating outcrop. Two intervals of crossover indicate U enrichment relative to Th and $\mathrm{K}$. 


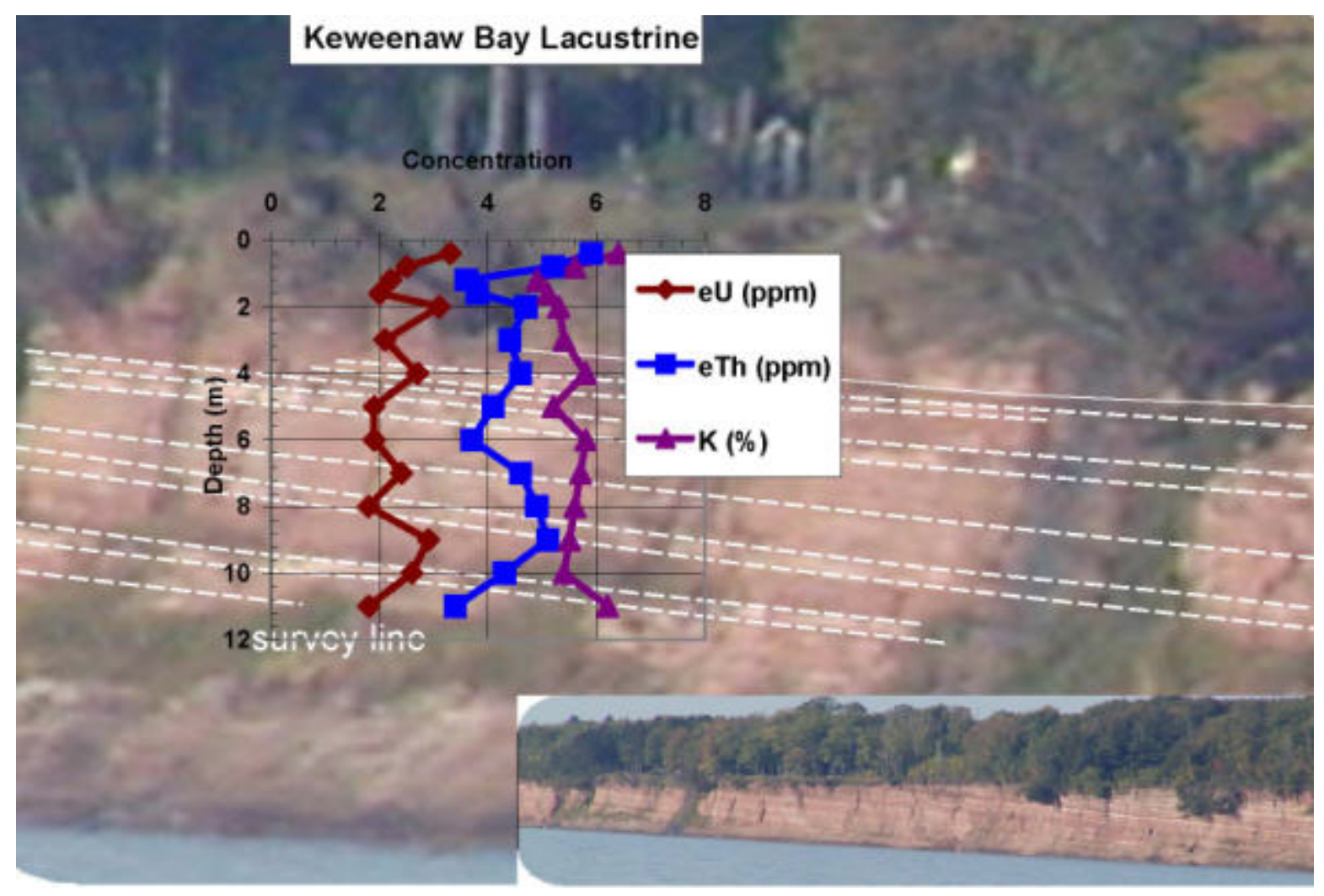

Figure $22 \mathrm{U}$, Th and K curves for the Keweenaw Bay Lacustrine outcrop. Uranium concentrations are relatively low compared to other outcrops. The land owner's well has low U. 


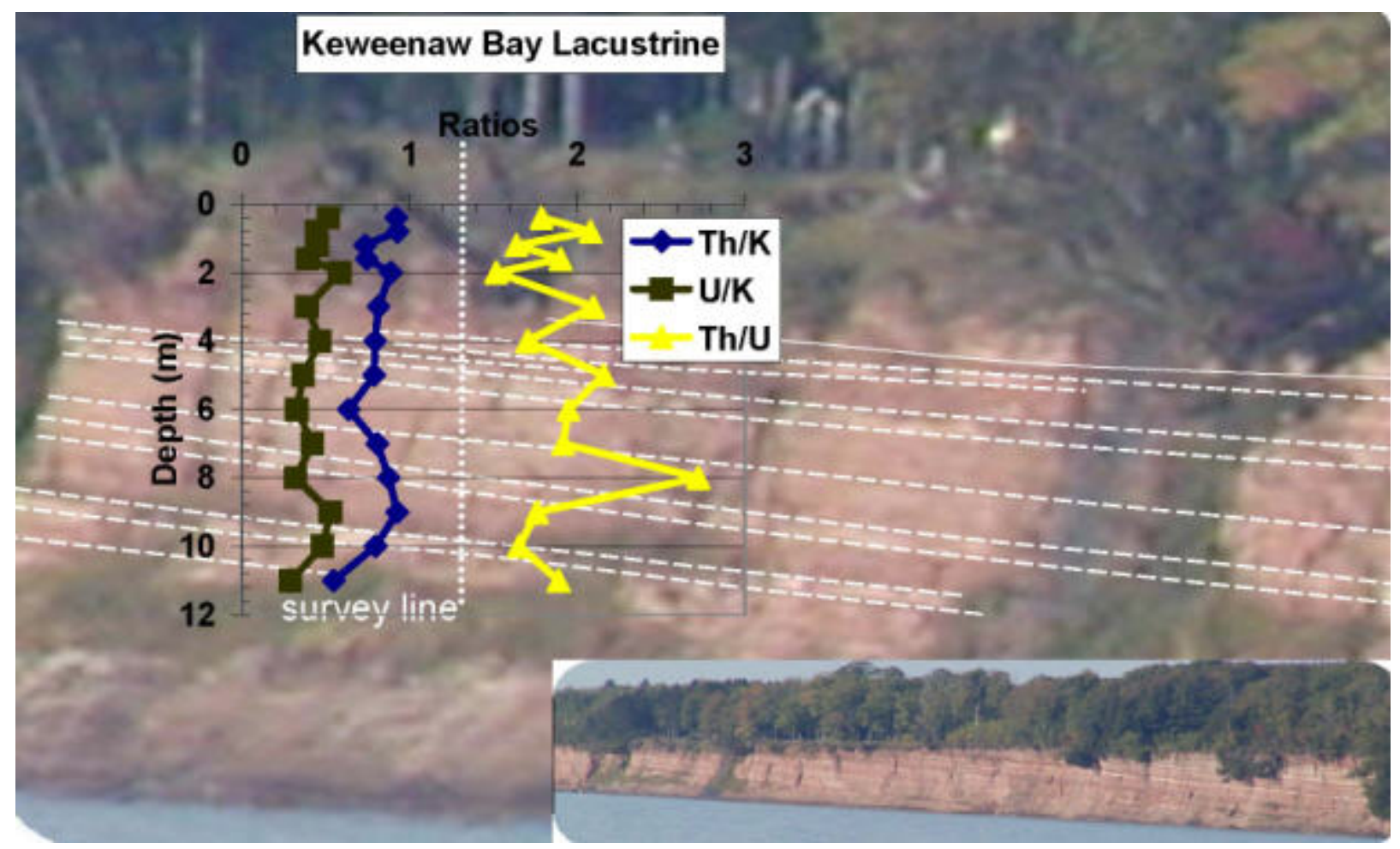

Figure $23 \mathrm{U}$, Th and $\mathrm{K}$ ratio curves for the Keweenaw Bay Lacustrine outcrop. Outcrop does not show intervals of U enrichment relative to Th and $\mathrm{K}$. 


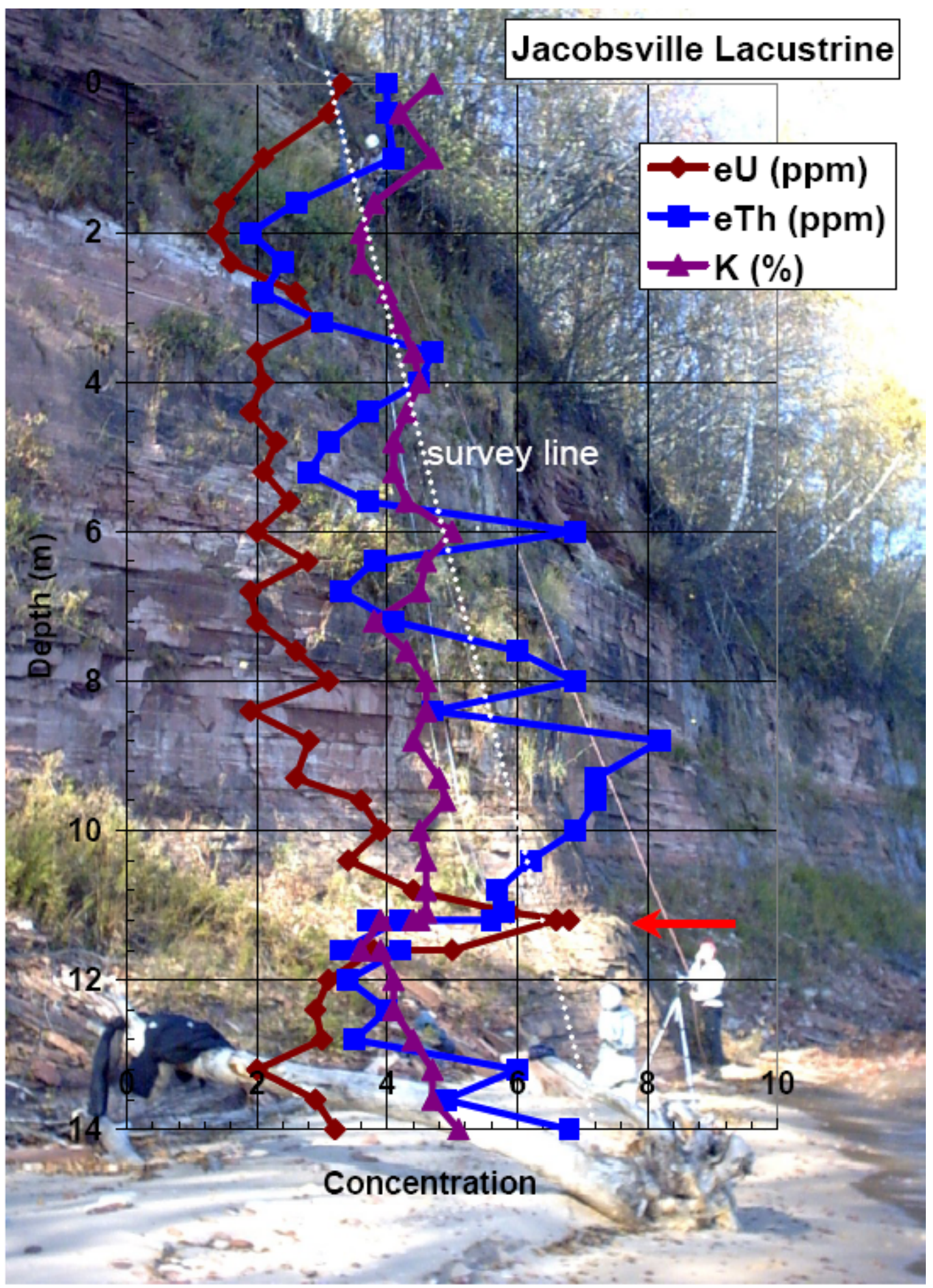

Figure $24 \mathrm{U}$, Th and $\mathrm{K}$ curves for the Jacobsville Lacustrine outcrop. Uranium enrichment along a small ledge representing a contact between dune forms. The land owner's (deep) well has elevated U. 


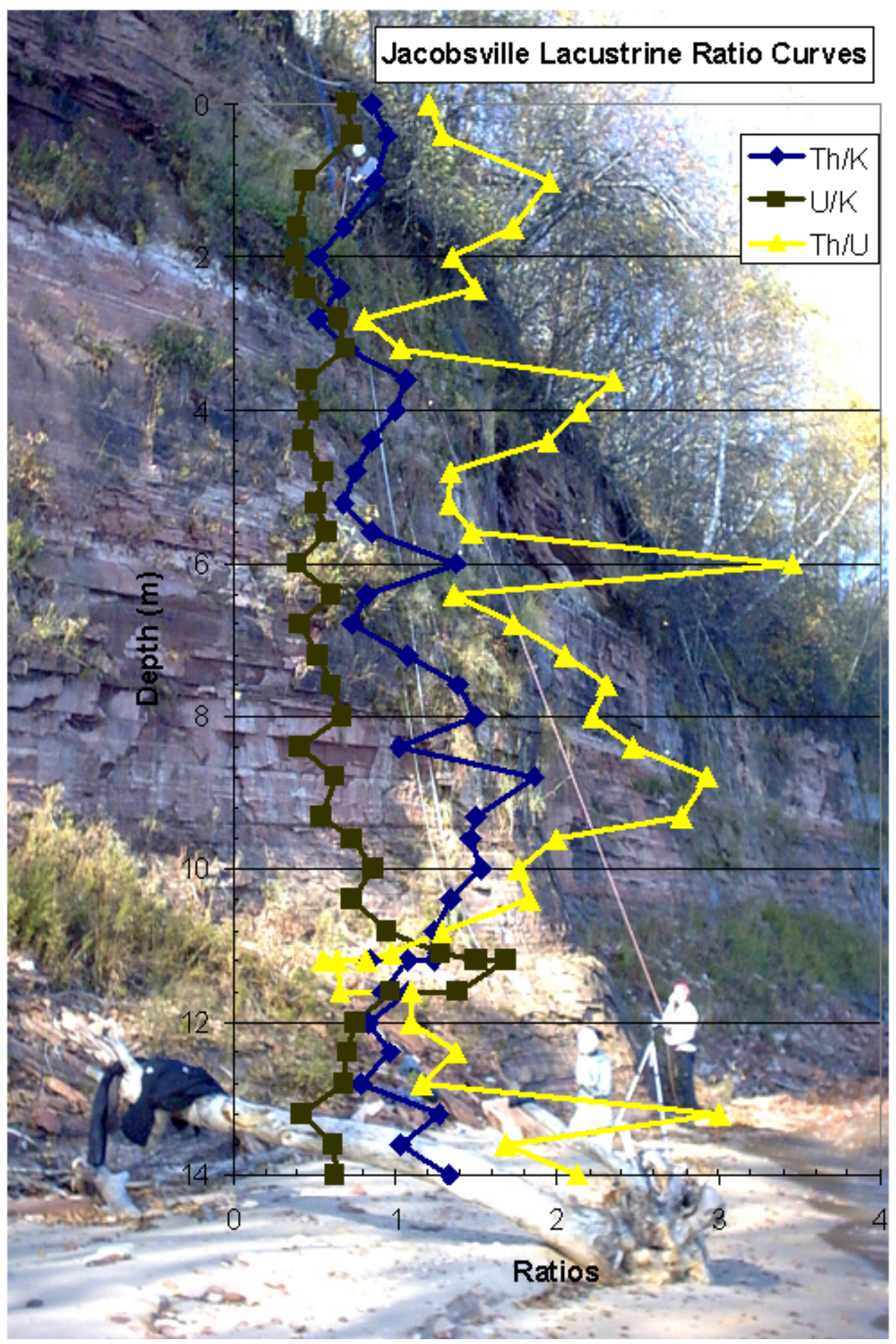

Figure $25 \mathrm{U}$, Th and $\mathrm{K}$ ratio curves for the Jacobsville Lacustrine outcrop. Crossover indicates $\mathrm{U}$ enrichment relative to $\mathrm{Th}$ and $\mathrm{K}$ along the contact, possibly due to groundwater flow. 


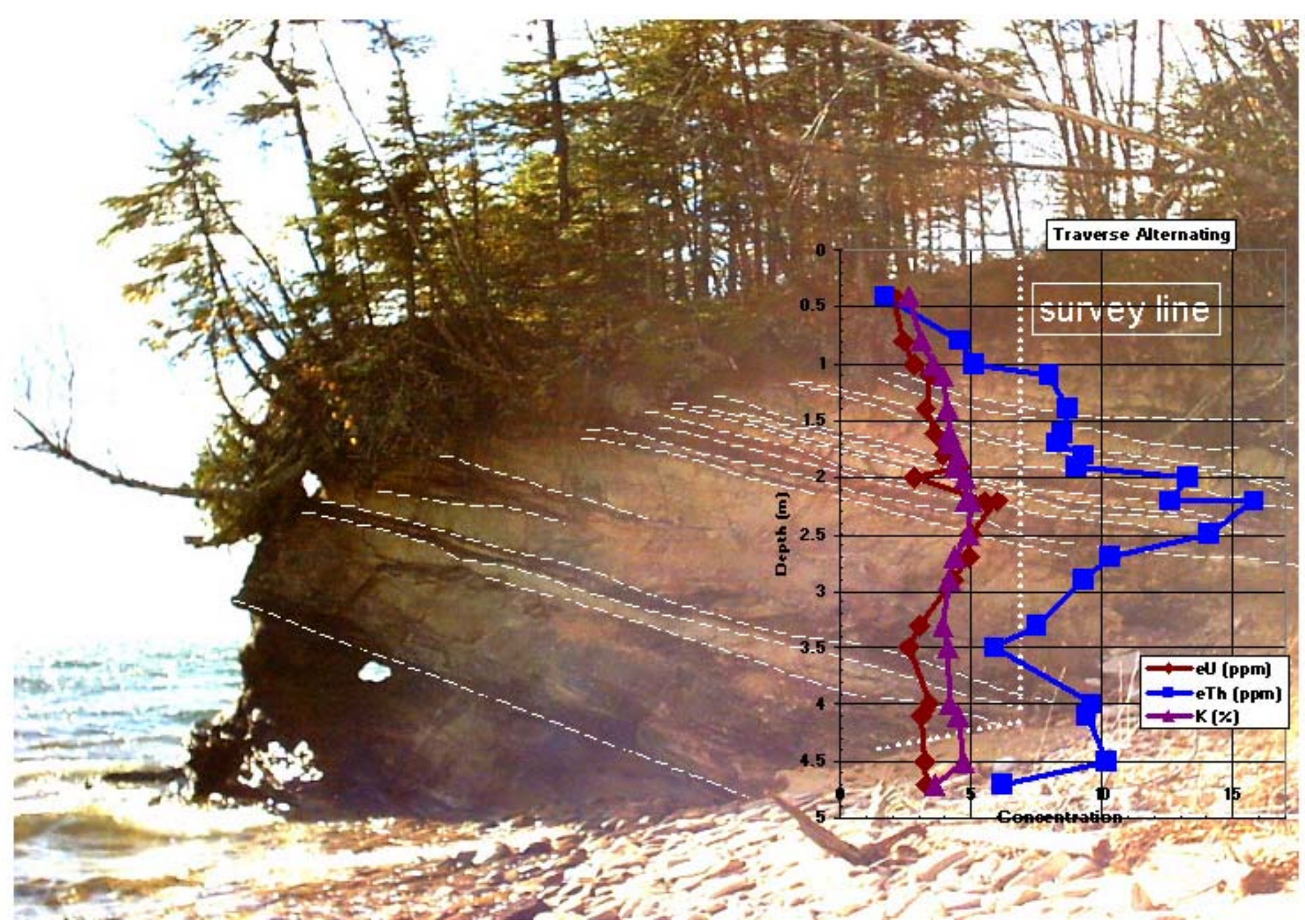

Figure $26 \mathrm{U}$, Th and $\mathrm{K}$ curves for the Traverse Alternating outcrop. Low U enrichment occurs in the mica rich, coarse white sandstone and is not strongly associated with the interbedded red siltstone layers. The outcrop shows high Th concentrations. 


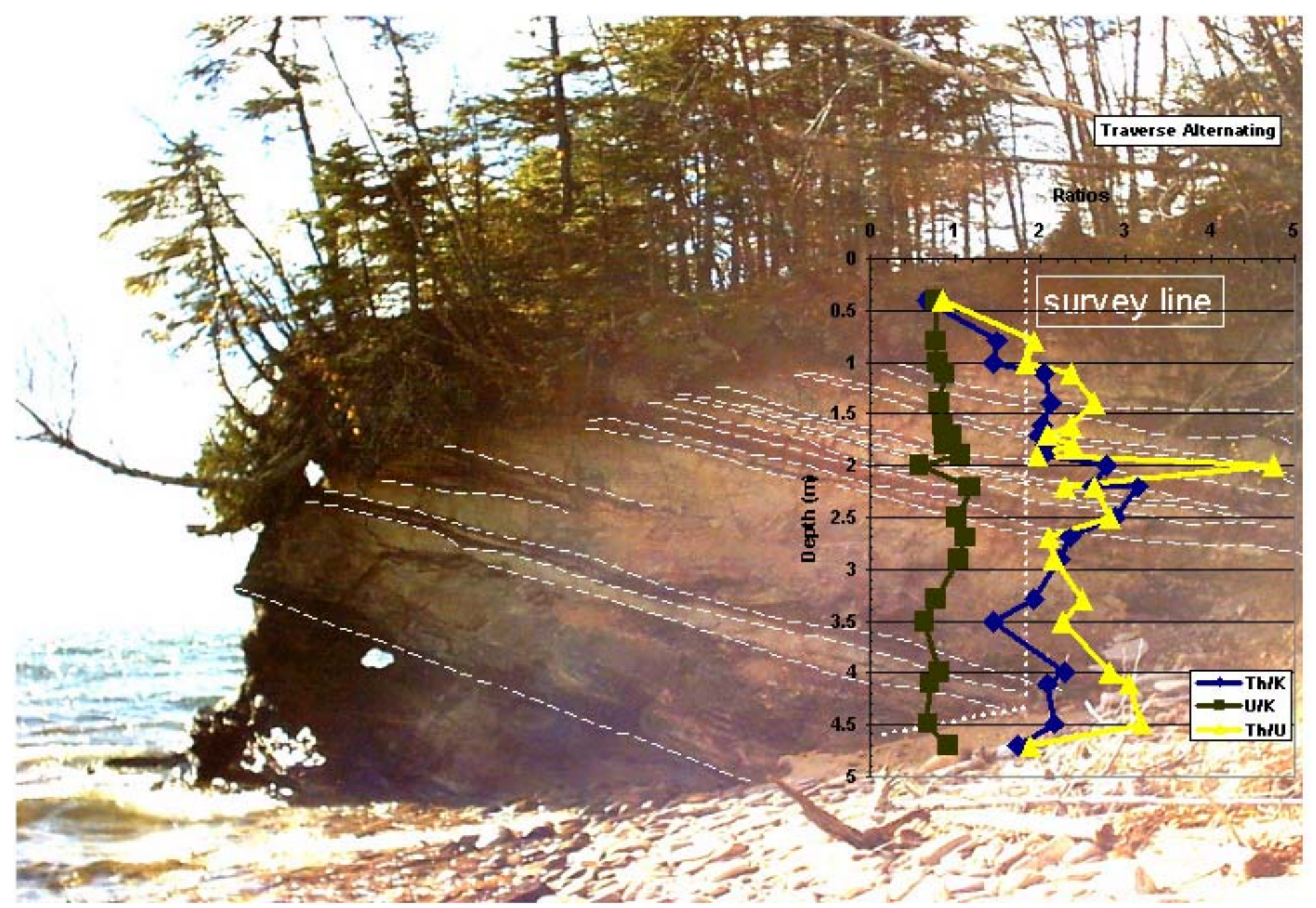

Figure $27 \mathrm{U}$, Th and $\mathrm{K}$ ratio curves for the Traverse Alternating outcrop. This outcrop does not show intervals of relative $\mathrm{U}$ enrichment. 


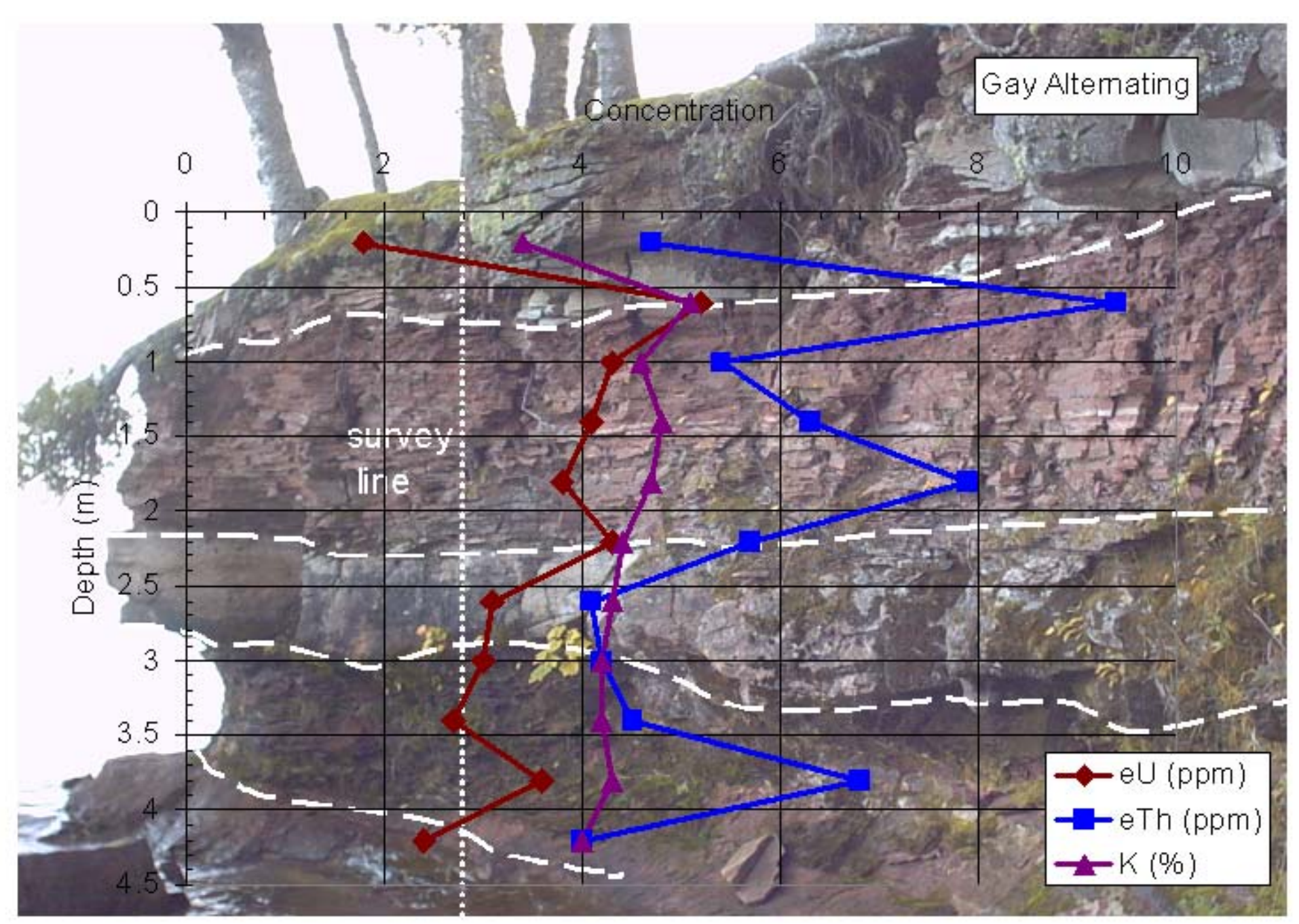

Figure $28 \mathrm{U}$, Th and K curves for the Gay Alternating outcrop. Low U enrichment is not strongly associated with the interbedded red silty layers. The log curves show greatest deflection at contacts between layers. The land owner's wells has elevated U. 


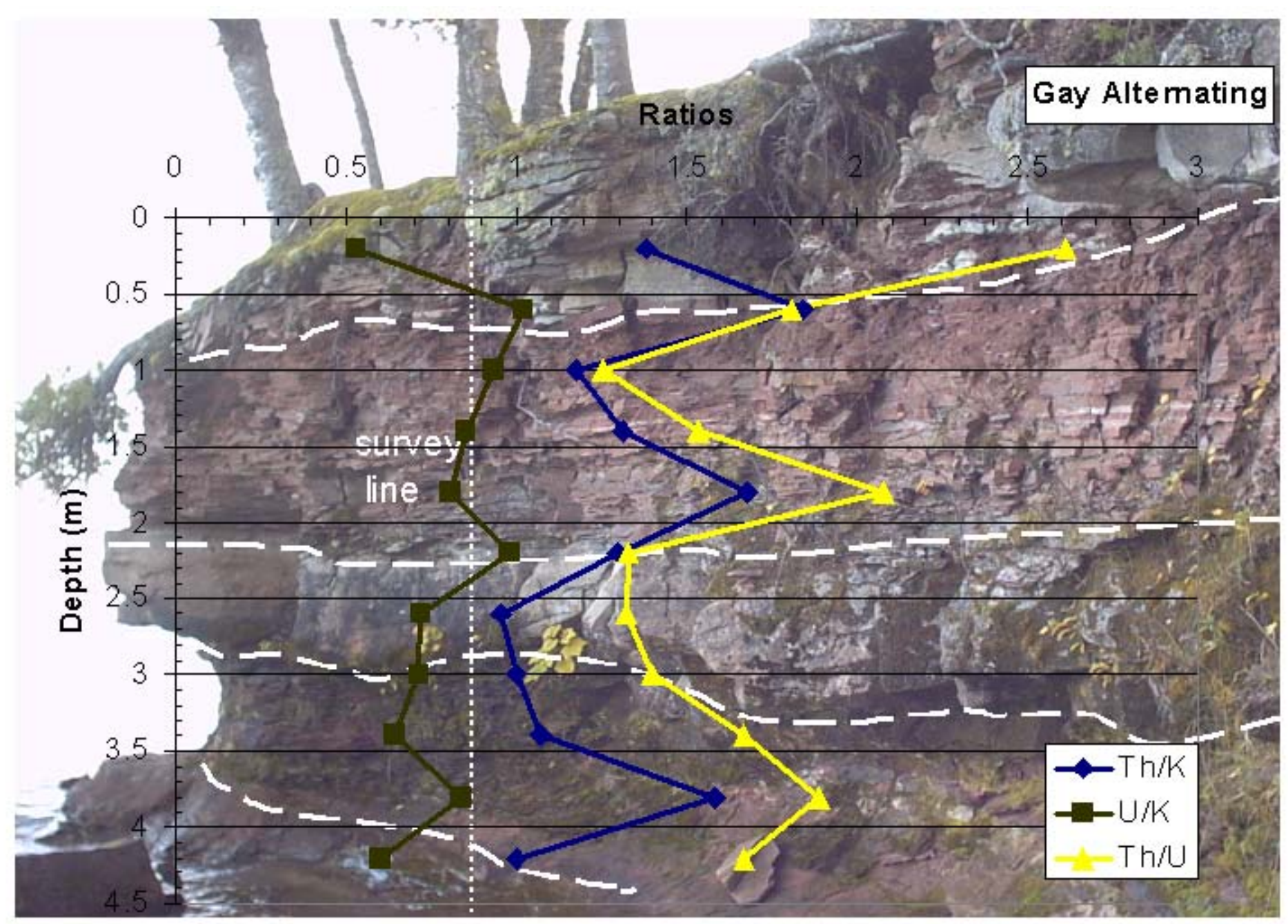

Figure 29 U, Th and K ratio curves for the Gay Alternating outcrop. This outcrop does not show intervals of relative U enrichment. 


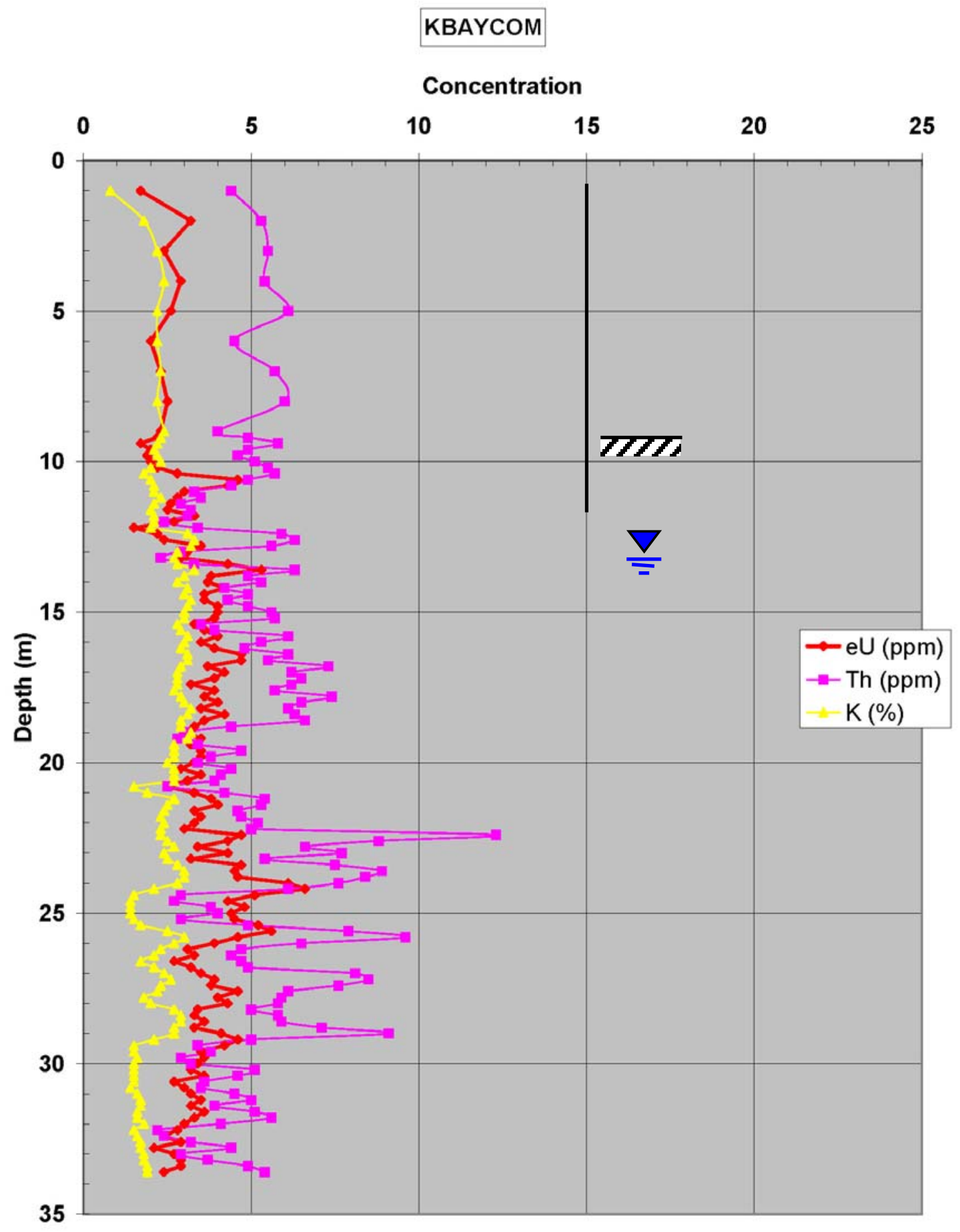

Figure $30 \mathrm{U}$, Th and K curves for the KBAYCOM well. Symbols indicate depth of casing (black line), top of sandstone (hatched lines) and water (blue triangle). This well shows intervals of U>5ppm and produces water with about $25 \mathrm{ppb}$ U. Elevation $210 \mathrm{~m}$ amsl. 


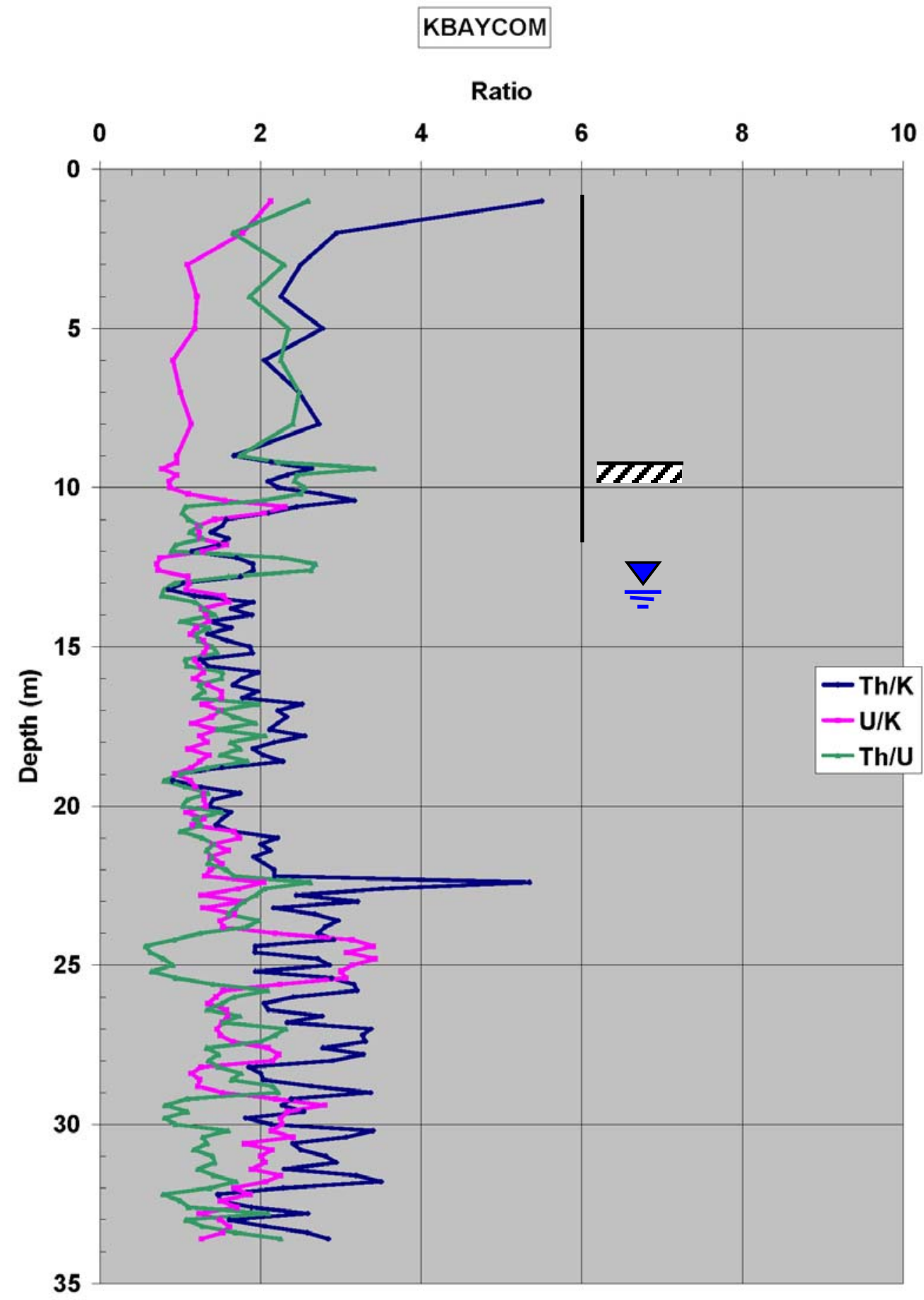

Figure $31 \mathrm{U}$, Th and $\mathrm{K}$ ratio curves for the KBAYCOM well. Cross over (U/K > Th/U) occurs in $48 \%$ of measurements. 


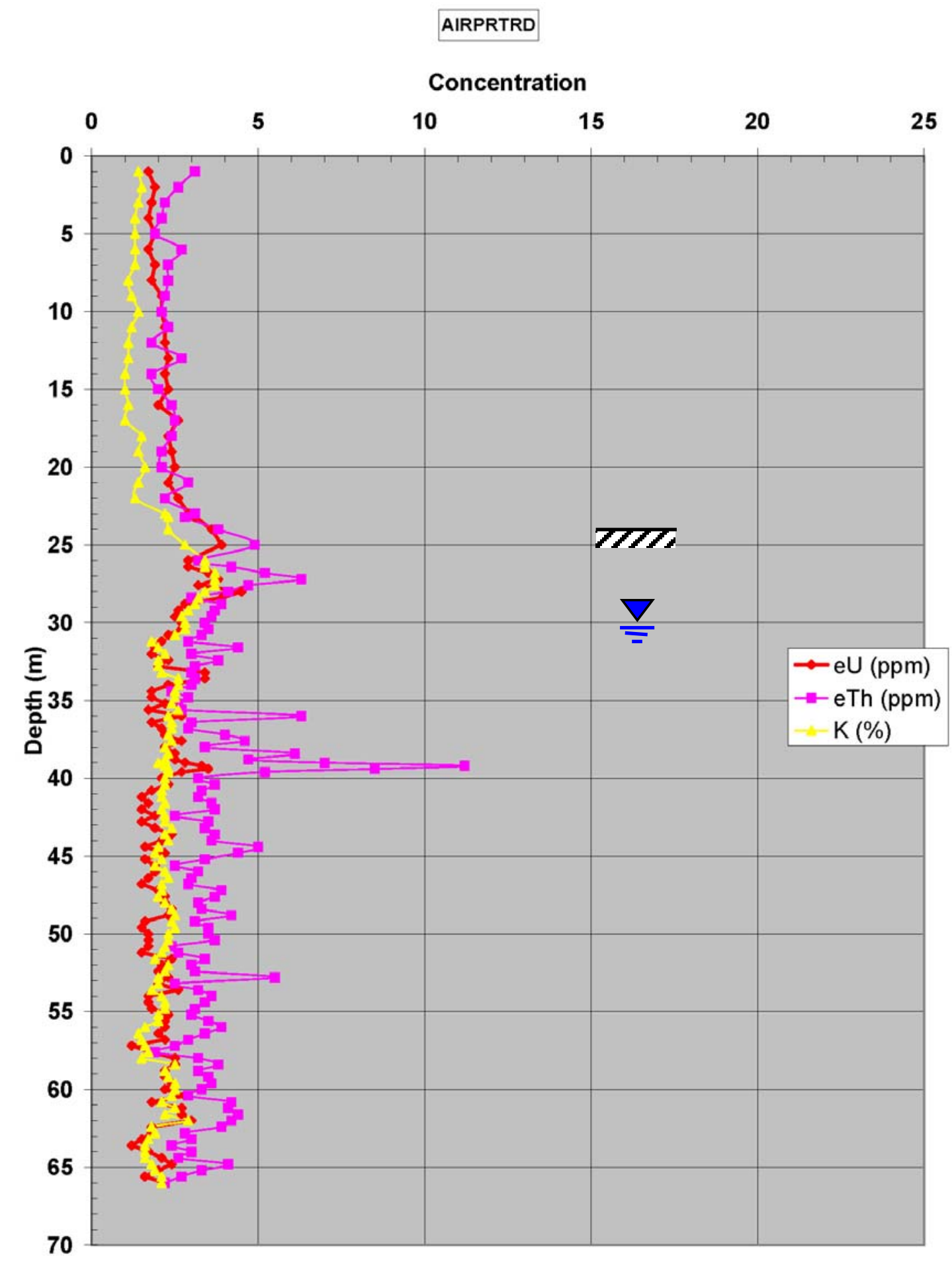

Figure $32 \mathrm{U}$, Th and $\mathrm{K}$ curves for the AIRPRTRD well. Uranium is below $5 \mathrm{ppm}$. (Waiting for a pump to collect a water sample). Elevation $300 \mathrm{~m}$ amsl. 


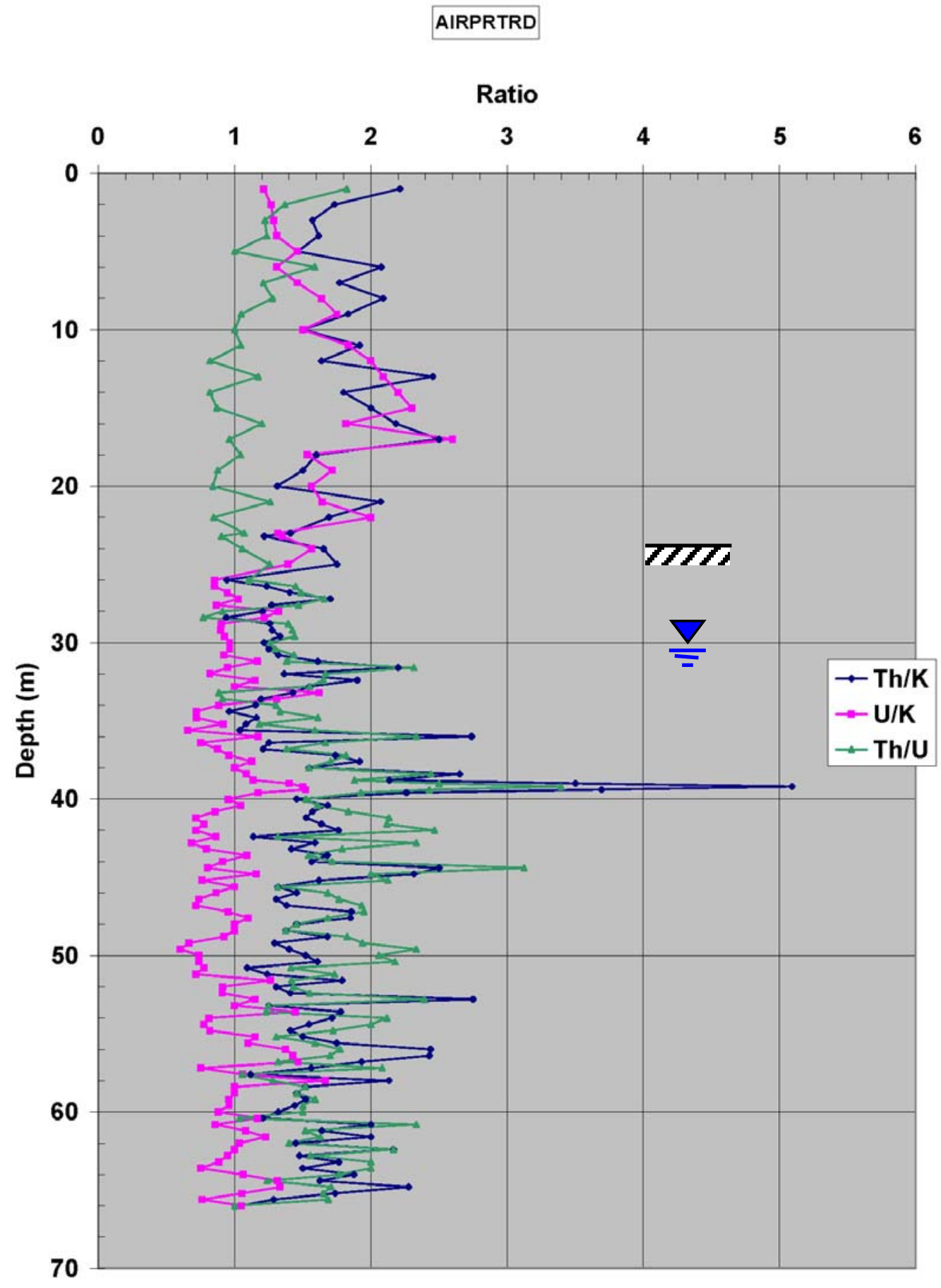

Figure $33 \mathrm{U}$, Th and $\mathrm{K}$ ratio curves for the AIRPRTRD well. Cross over (U/K $>\mathrm{Th} / \mathrm{U})$ occurs in $26 \%$ of measurements. 


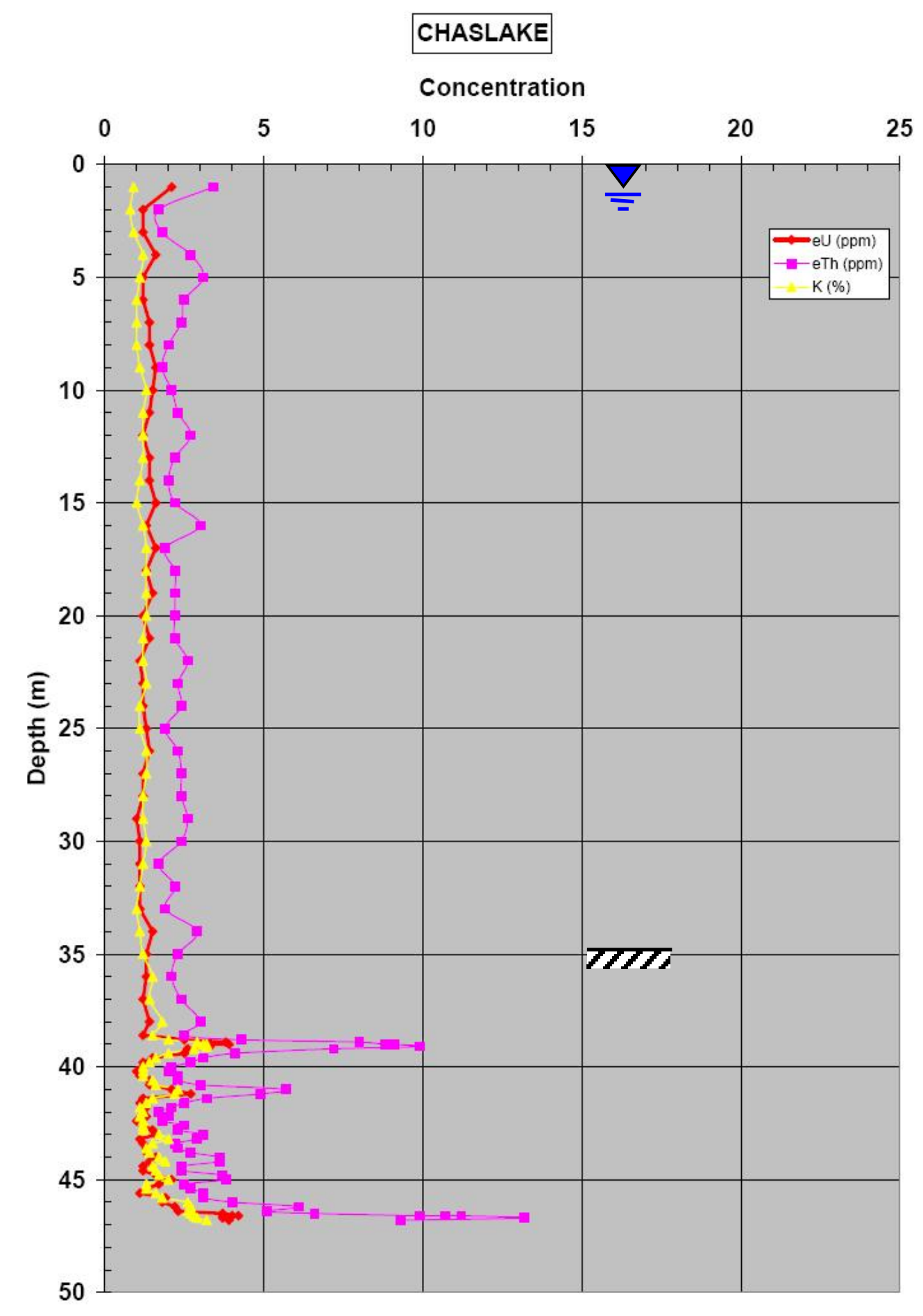

Figure $34 \mathrm{U}$, Th and $\mathrm{K}$ curves for the CHASLAKE well. The well was abandoned based on slightly elevated $\mathrm{U}(33 \mathrm{pCi} / \mathrm{L})$. Note: the upper portion of the well is cased in surficial material. The groundwater flow path likely encountered higher $U$ intervals up hill. Elevation $185 \mathrm{~m}$ amsl. 


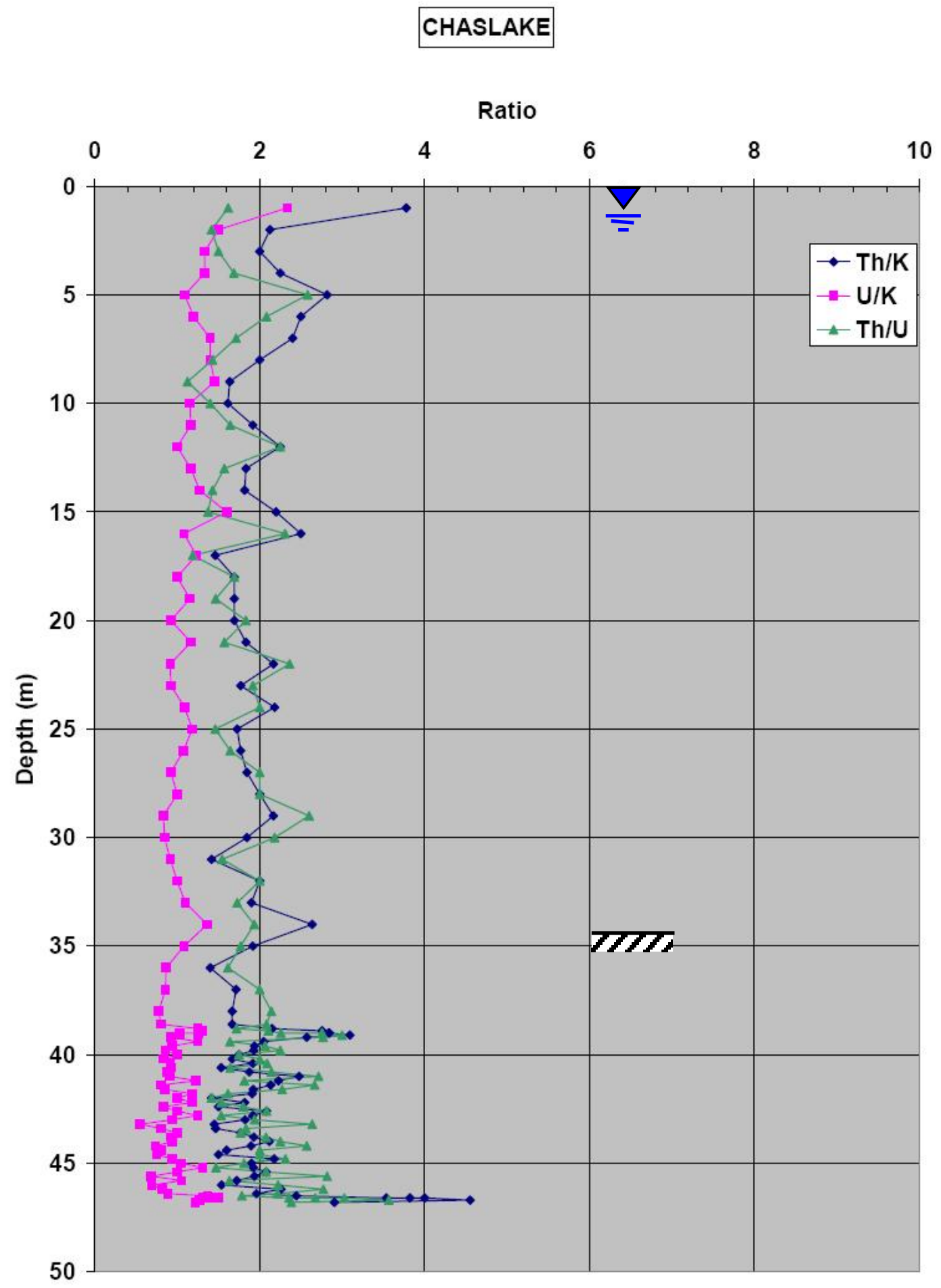

Figure $35 \mathrm{U}$, Th and $\mathrm{K}$ ratio curves for the CHASLAKE well. Cross over (U/K > Th/U) occurs in $5 \%$ of measurements. 


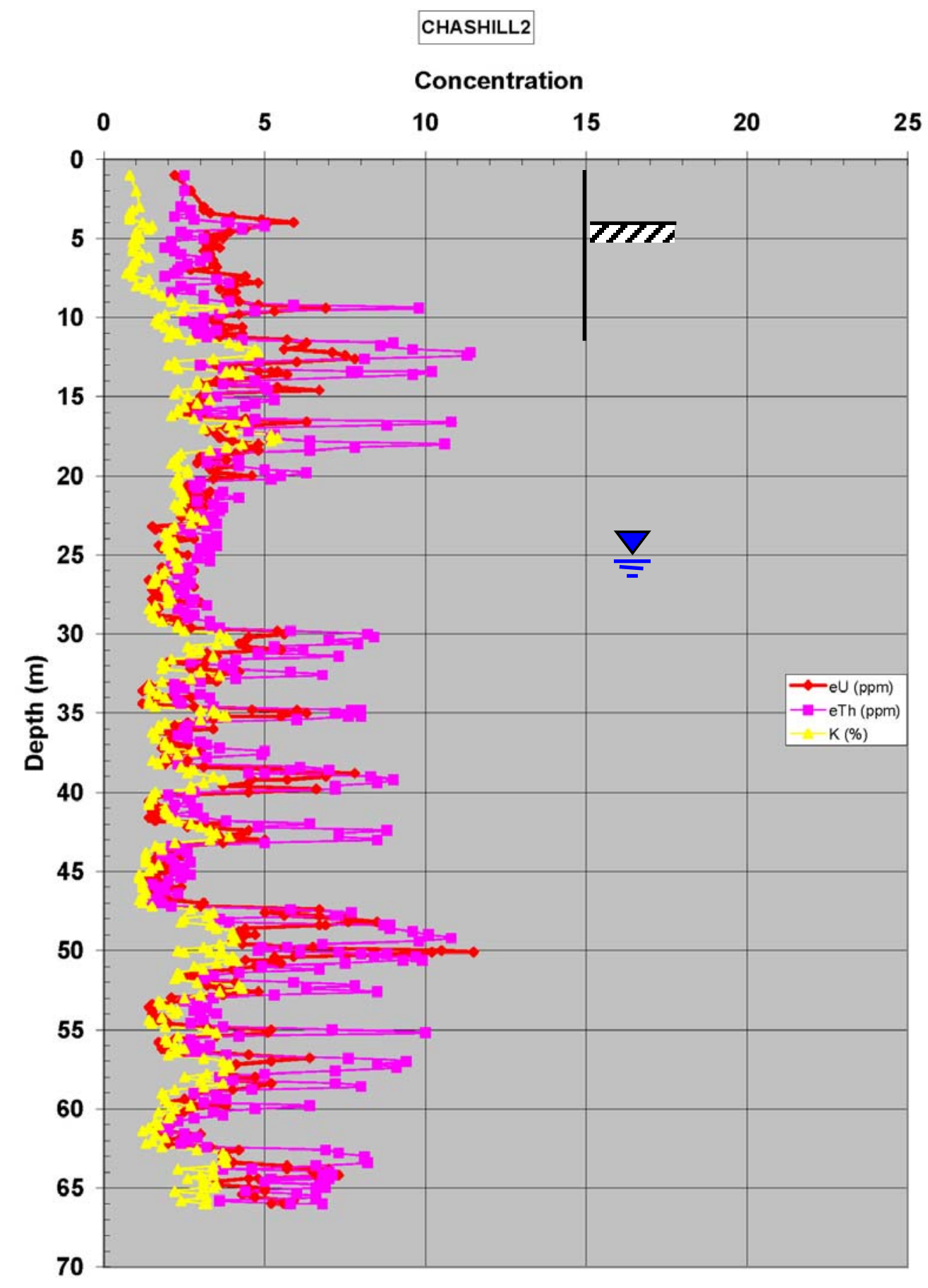

Figure $36 \mathrm{U}$, Th and $\mathrm{K}$ curves for the CHASHILL2 well. The effects of $\mathrm{U}$ enrichment are evidently modified by other hydrogeochemical factors as the well produces water with moderate $(7.9 \mathrm{ppb}) \mathrm{U}$ concentration. Elevation $238 \mathrm{~m}$ amsl. 


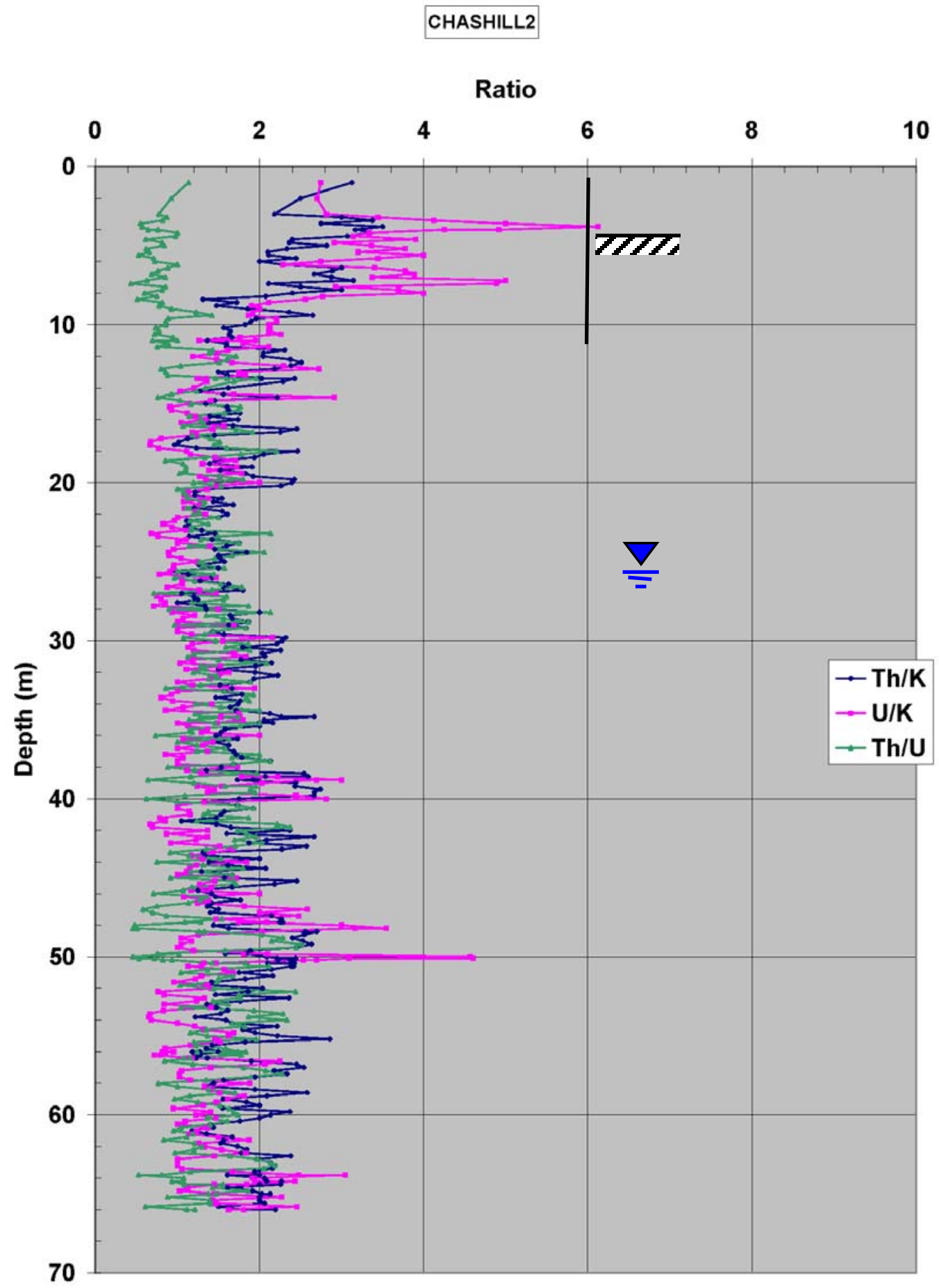

Figure $37 \mathrm{U}$, Th and $\mathrm{K}$ ratio curves for the CHASHILL2 well. Cross over $(\mathrm{U} / \mathrm{K}>\mathrm{Th} / \mathrm{U})$ occurs in $51 \%$ of measurements. 


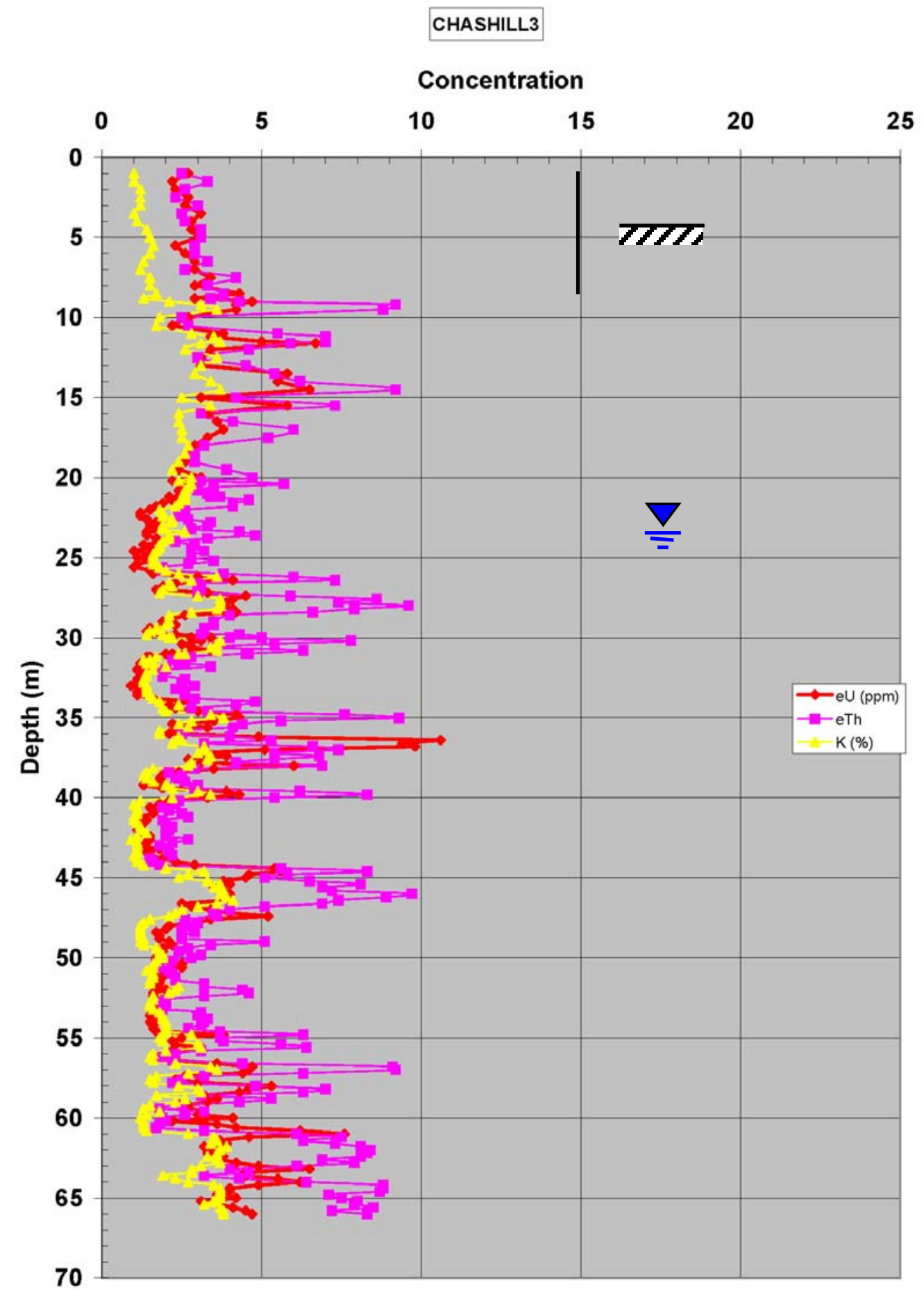

Figure $38 \mathrm{U}$, Th and K curves for the CHASHILL3 well. Peaks on these curves correlate with the CHASHILL2 well indicating U rich strata are laterally continuous over 100s of feet. Like the CHASHILL2 well, this well produces water with moderate U concentration. Elevation $235 \mathrm{~m}$ amsl. 


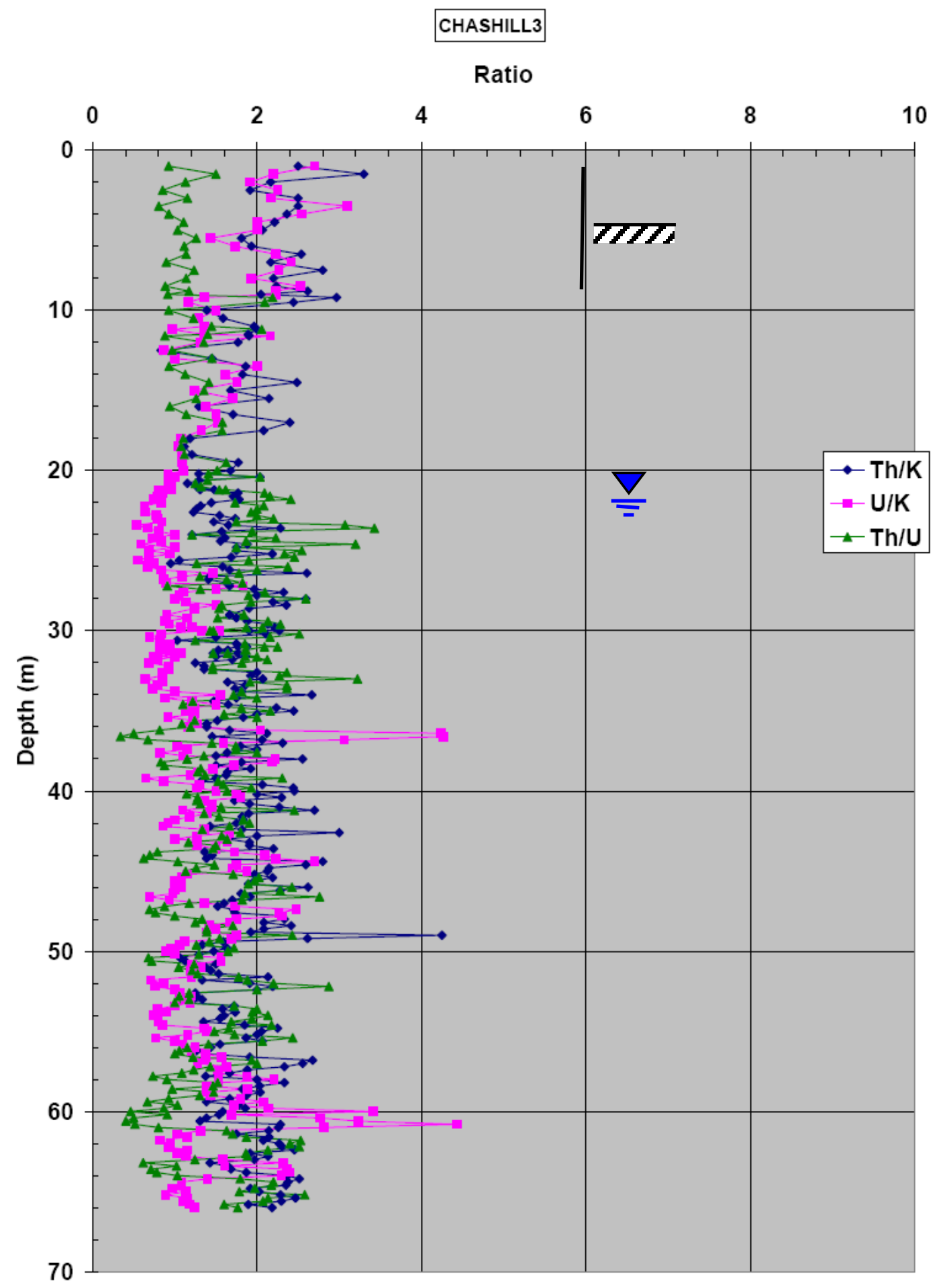

Figure $39 \mathrm{U}$, Th and $\mathrm{K}$ ratio curves for the CHASHILL3 well. Cross over $(\mathrm{U} / \mathrm{K}>\mathrm{Th} / \mathrm{U})$ occurs in $35 \%$ of measurements. 


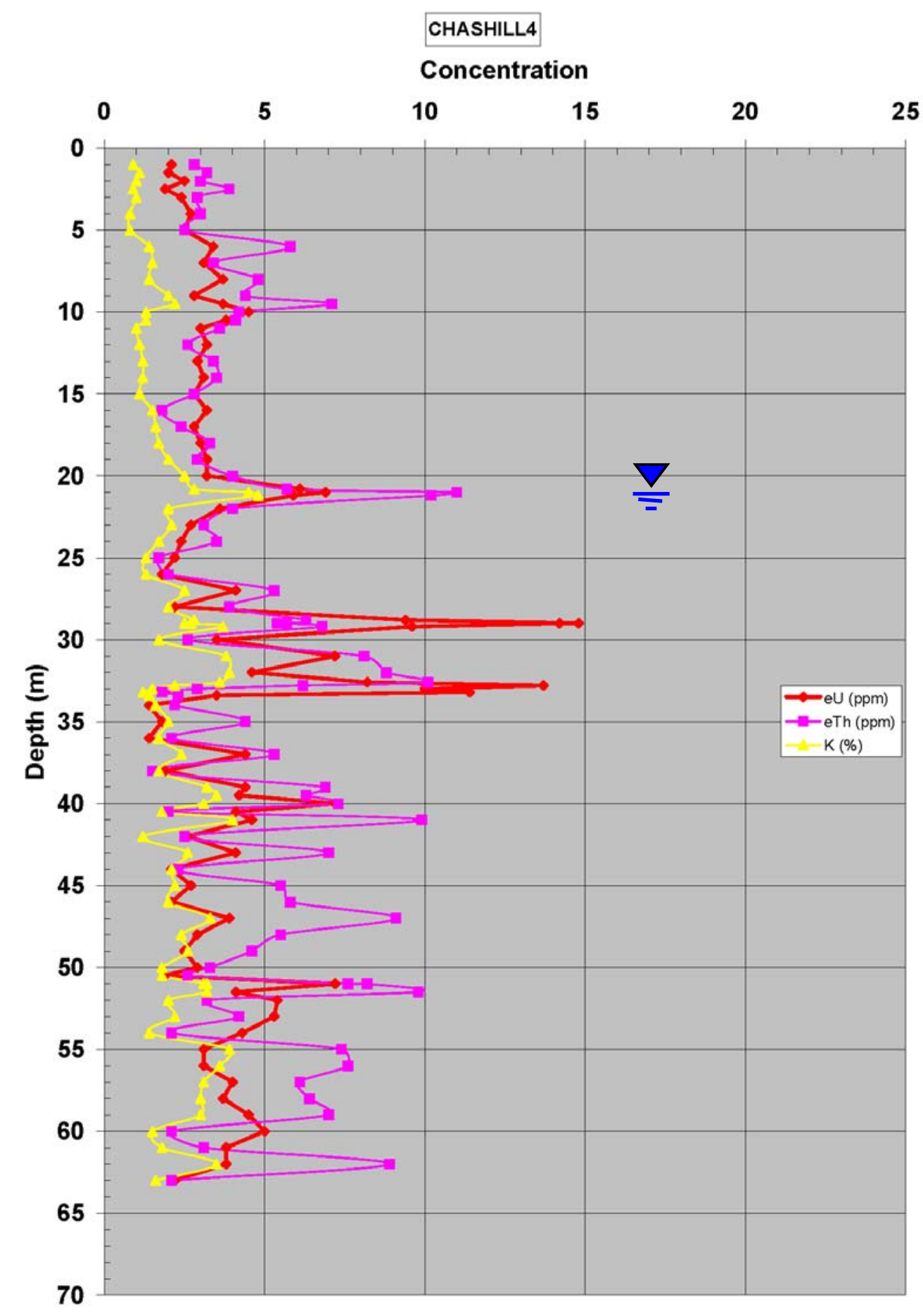

Figure $40 \mathrm{U}$, Th and $\mathrm{K}$ curves for the CHASHILL4 well. This well shows $\mathrm{U}$ enrichment and produces water with $18.6 \mathrm{ppb}$, somewhat elevated, but below the MCL. Elevation $232 \mathrm{~m}$ amsl. 


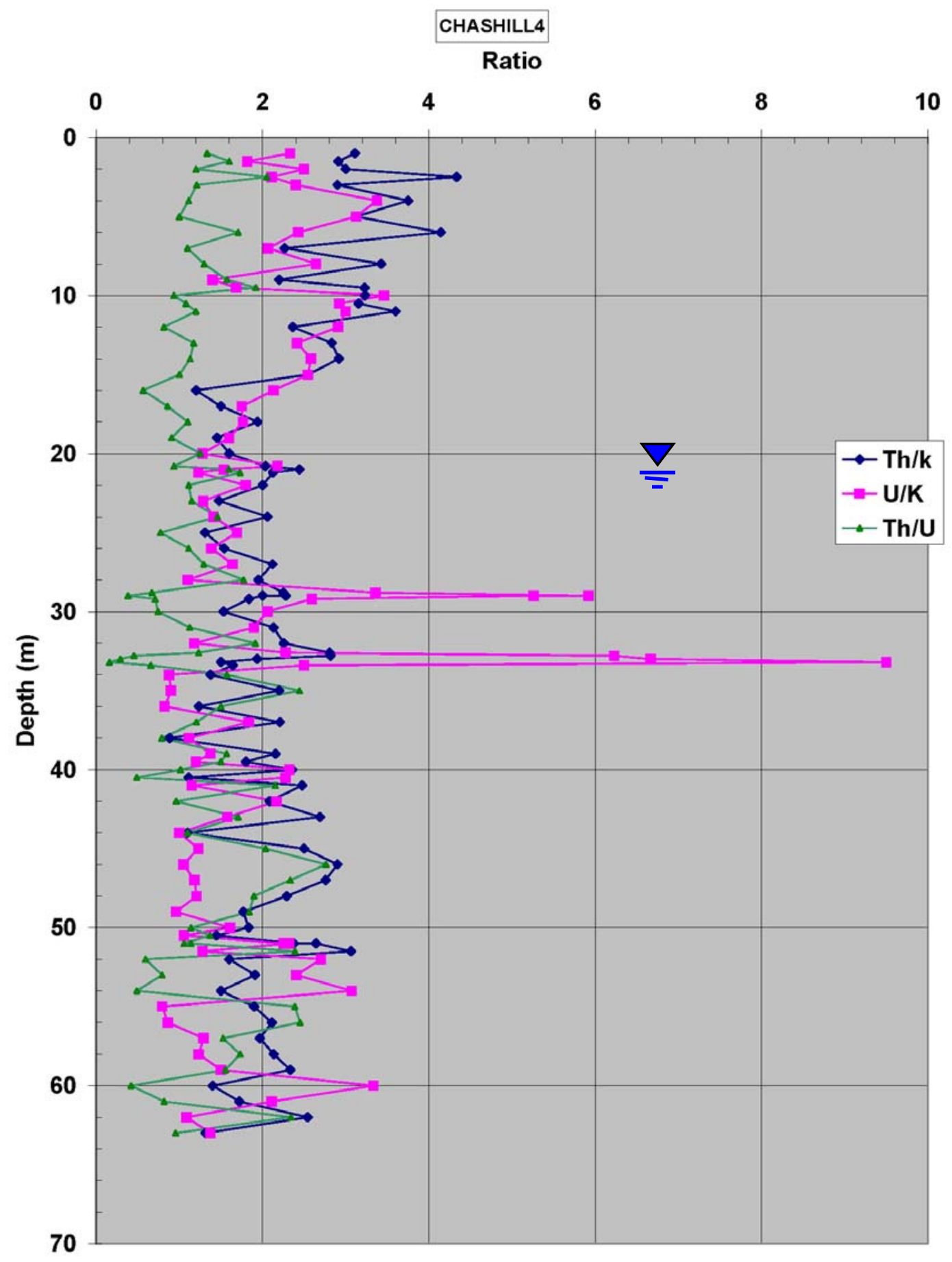

Figure $41 \mathrm{U}$, Th and $\mathrm{K}$ ratio curves for the CHASHILL4 well. Note intervals with high $\mathrm{U}$ enrichment relative to Th and $\mathrm{K}$. Cross over $(\mathrm{U} / \mathrm{K}>\mathrm{Th} / \mathrm{U})$ occurs in $65 \%$ of measurements. 


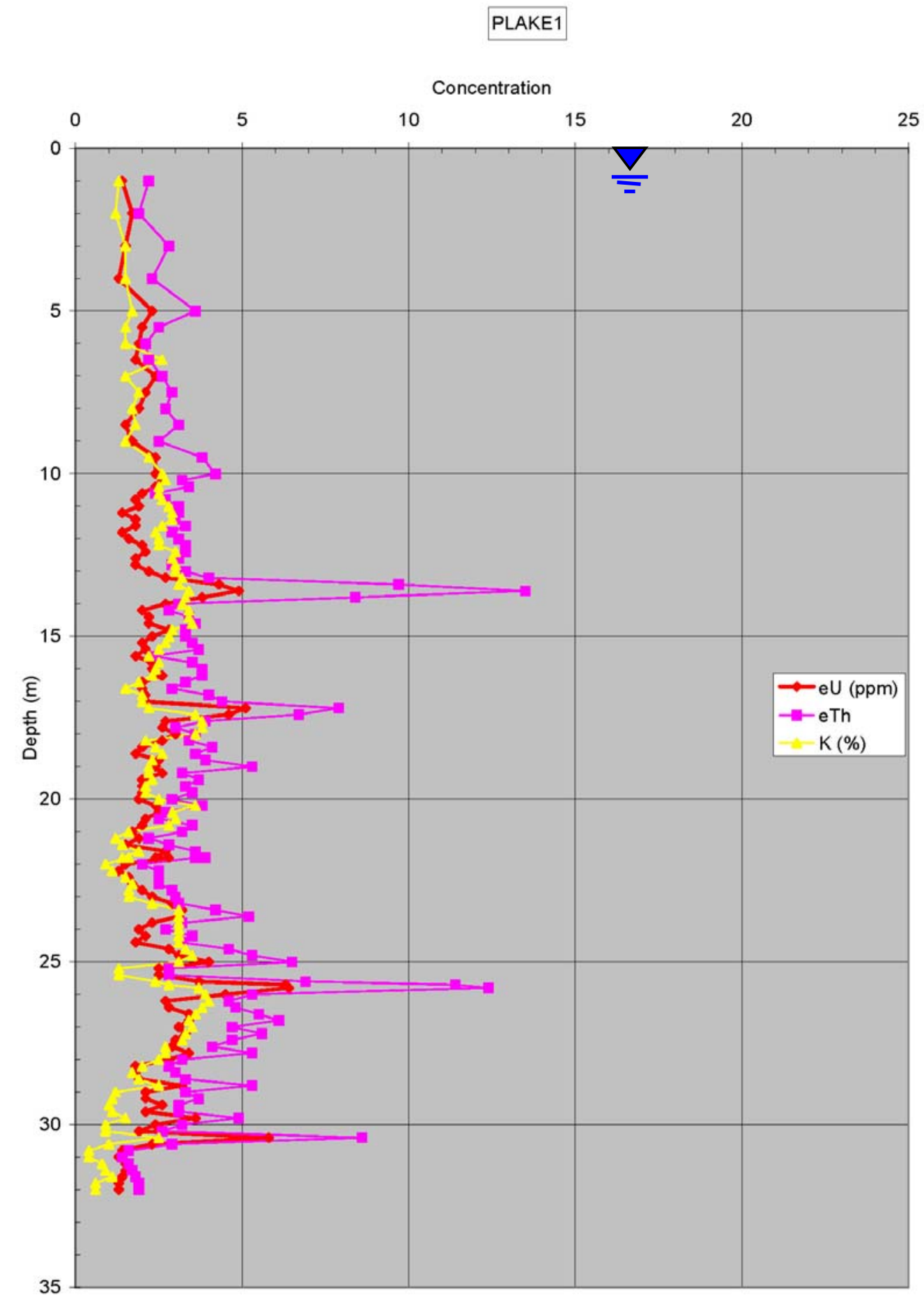

Figure $42 \mathrm{U}$, Th and K curves for the PLAKE1 well. This well shows moderate U enrichment on the log and produces water with about $54 \mathrm{ppb} U$. Intervals of U enrichment correlate with The enrichment. Elevation $185 \mathrm{~m}$ amsl. 


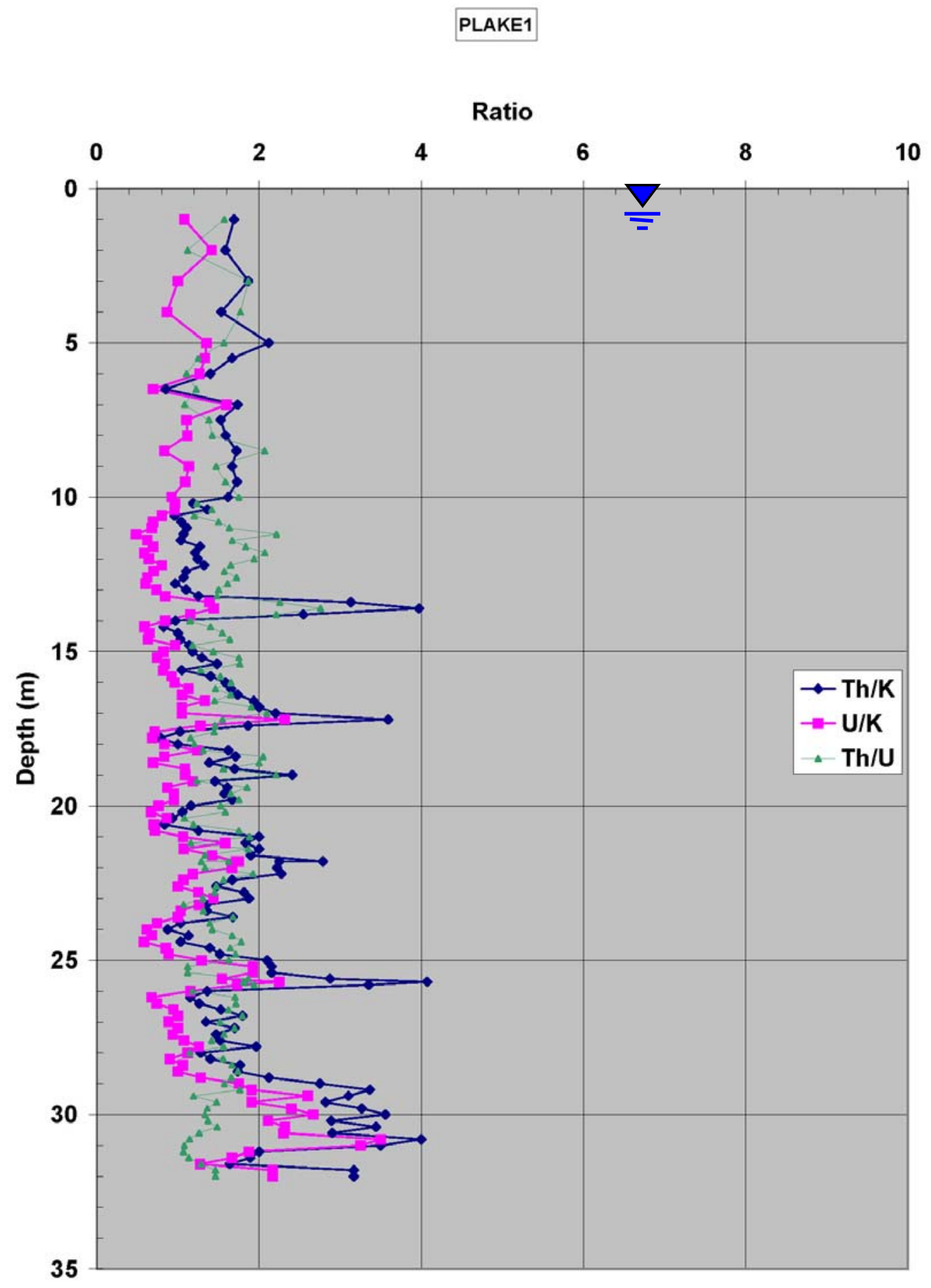

Figure $43 \mathrm{U}$, Th and $\mathrm{K}$ ratio curves for the PLAKE1well. Cross over (U/K > Th/U) occurs in $24 \%$ of measurements. 


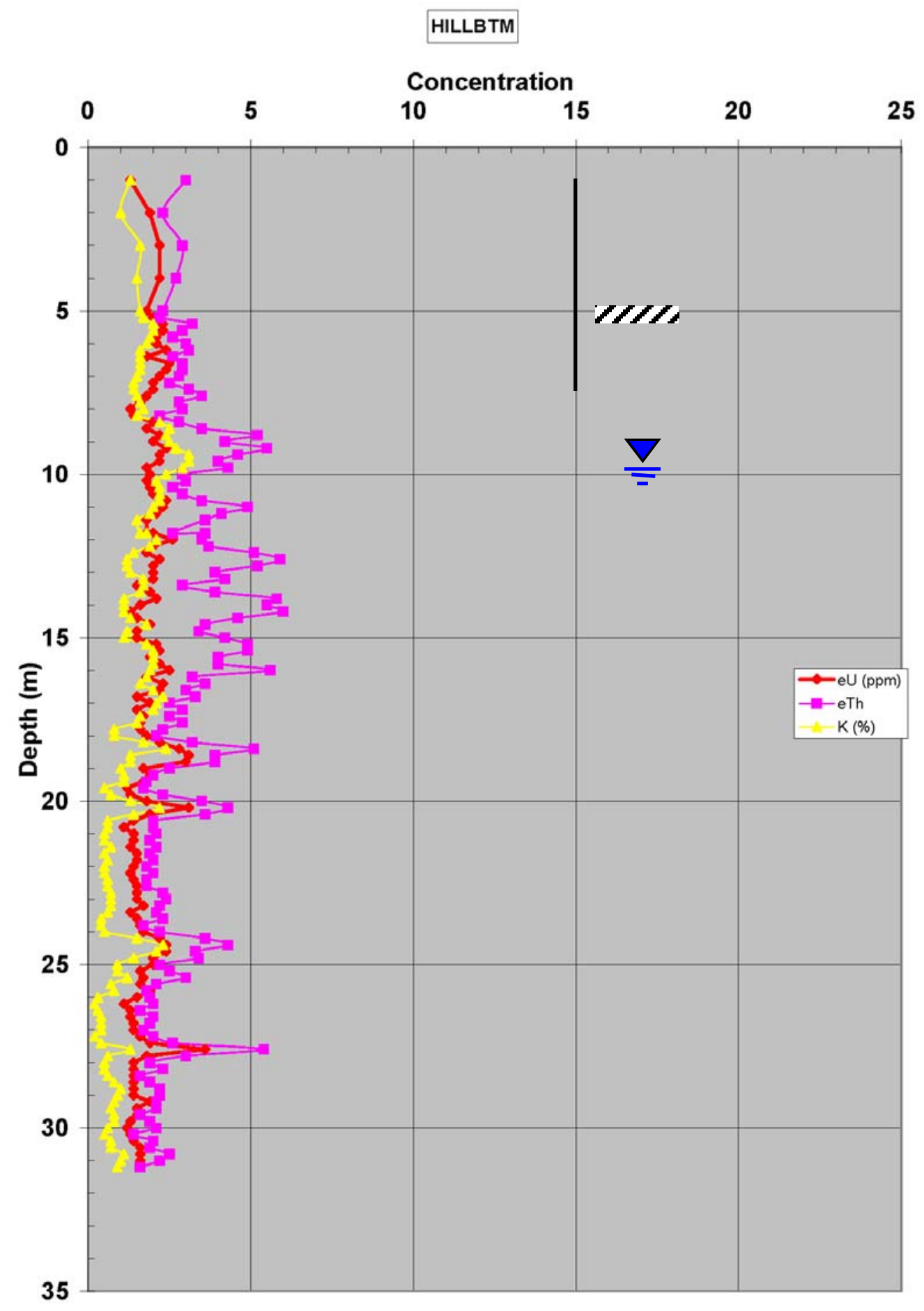

Figure $44 \mathrm{U}$, Th and K curves for the HILLBTM well. This well $\log$ shows $<5$ ppm $\mathrm{U}$ on the log and produces water with about $1 \mathrm{ppb}$ U. Elevation $225 \mathrm{~m}$ amsl. 


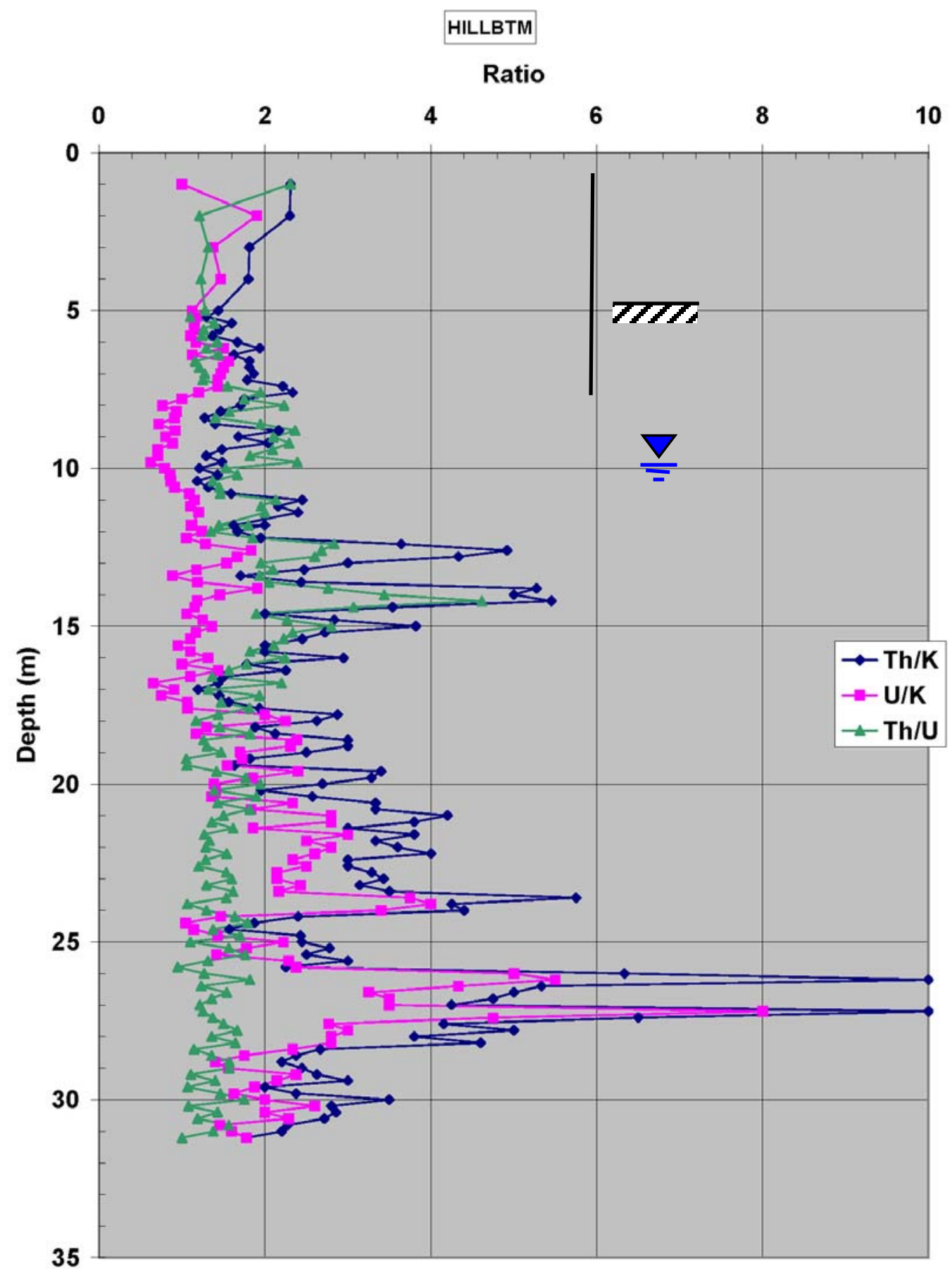

Figure $45 \mathrm{U}$, Th and $\mathrm{K}$ ratio curves for the HILLBTM well. This well produces water with low $\mathrm{U}$ in spite of significant $(48 \%)$ crossover $(\mathrm{U} / \mathrm{K}>\mathrm{Th} / \mathrm{U})$. 


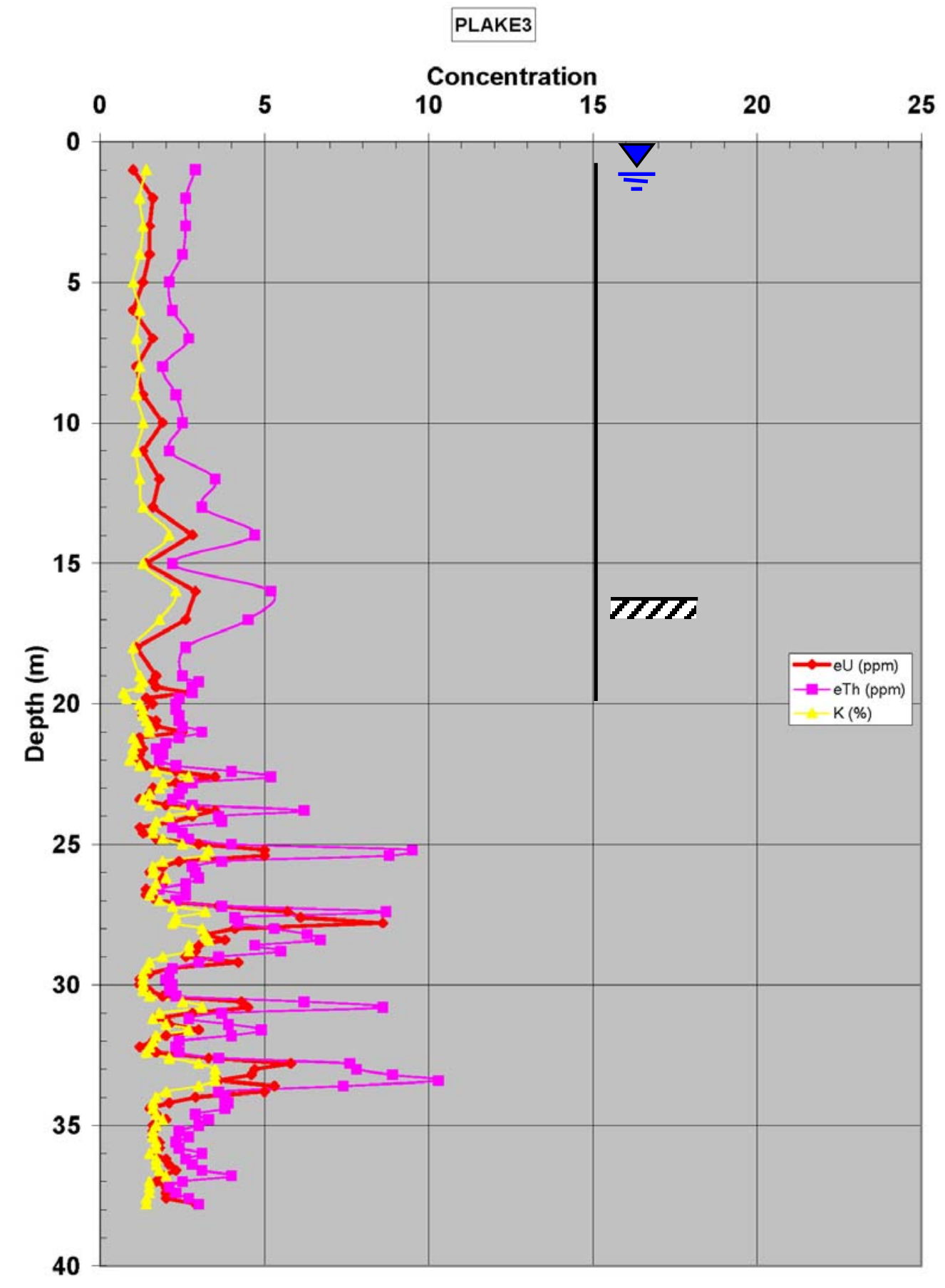

Figure $46 \mathrm{U}$, Th and K curves for the PLAKE3 well. The well log shows $\mathrm{U}>5 \mathrm{ppm}$ and the well produces water with about $85 \mathrm{ppb}$ U. Elevation $186 \mathrm{~m}$ amsl. 


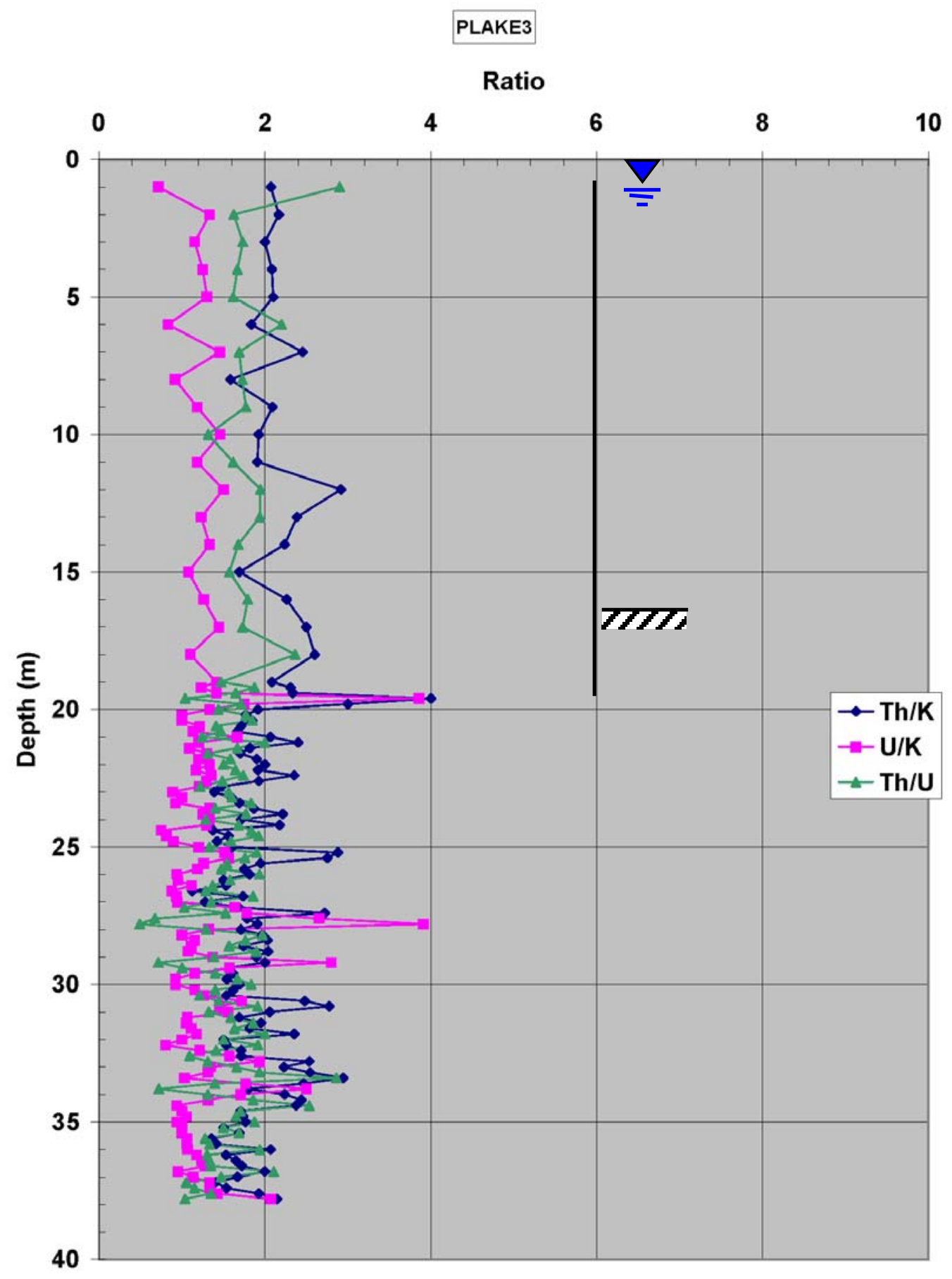

Figure $47 \mathrm{U}$, Th and $\mathrm{K}$ ratio curves for the PLAKE3 well. Cross over $(\mathrm{U} / \mathrm{K}>\mathrm{Th} / \mathrm{U})$ occurs in $21 \%$ of measurements. 


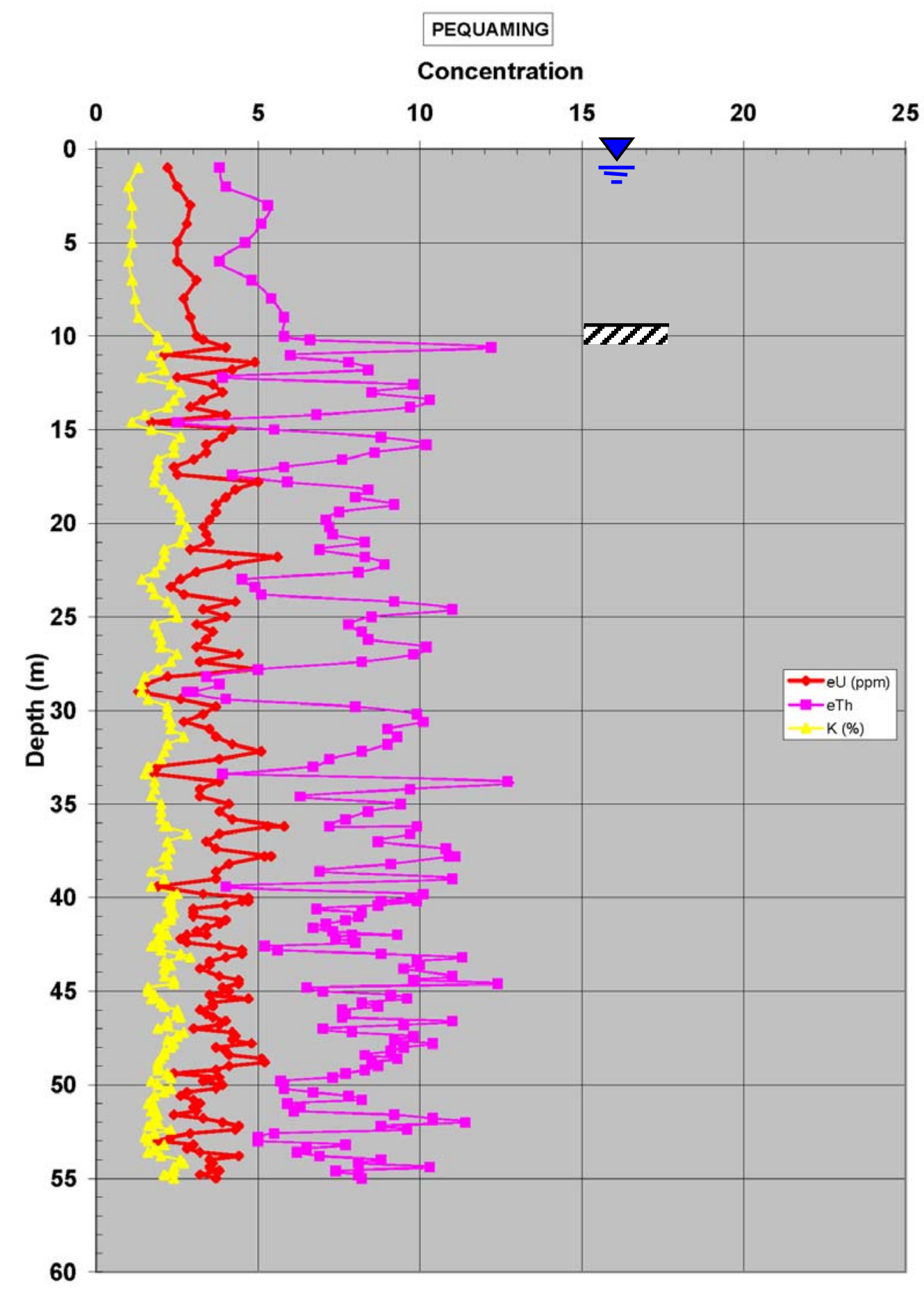

Figure $48 \mathrm{U}$, Th and $\mathrm{K}$ ratio curves for the PEQUAMING well. The well log shows frequent intervals of $5 \mathrm{ppm} \mathrm{U}$. The well produces water with $11 \mathrm{ppb}$. Elevation $184 \mathrm{~m}$ amsl. 


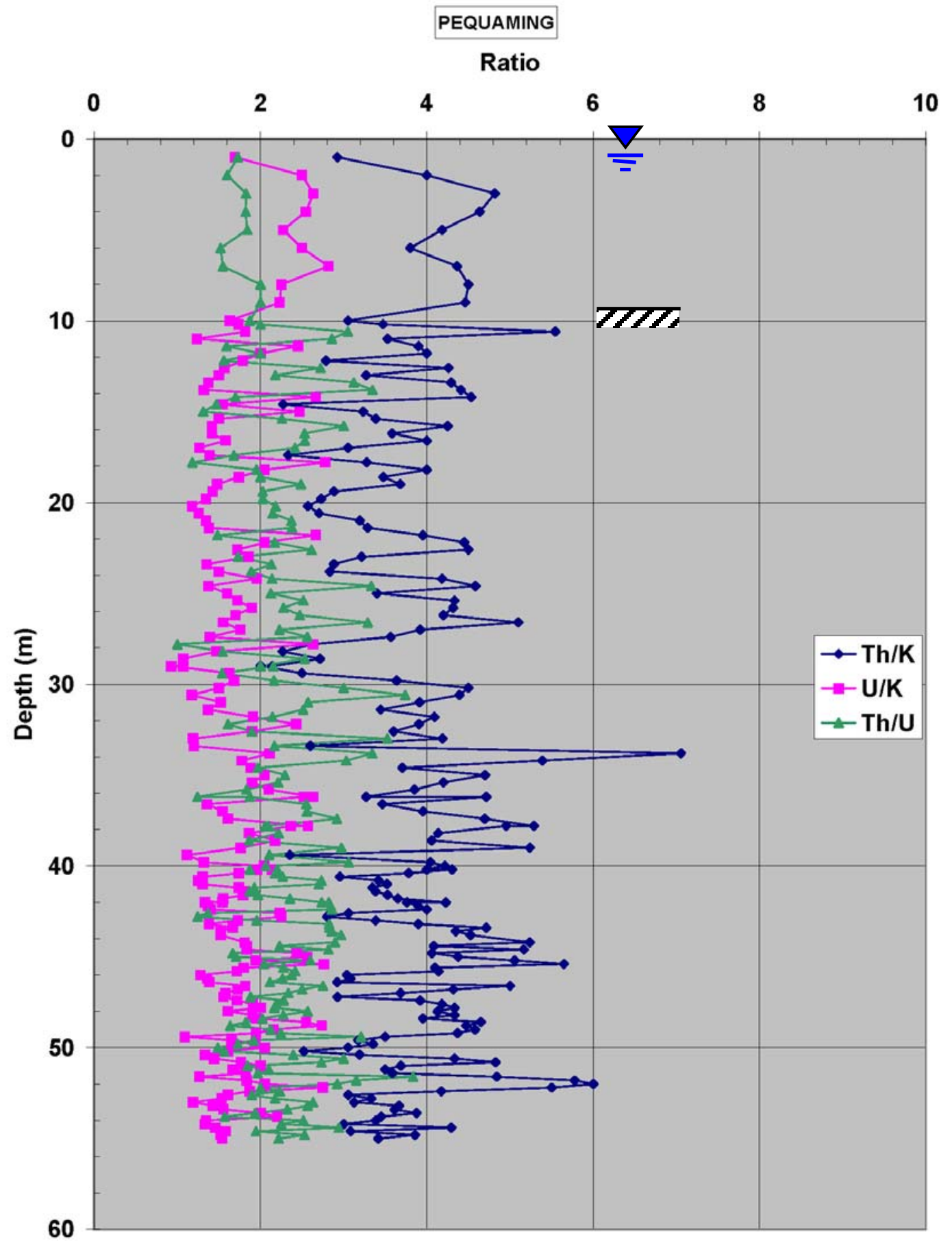

Figure $49 \mathrm{U}$, Th and $\mathrm{K}$ ratio curves for the PEQUAMING well. Cross over $(\mathrm{U} / \mathrm{K}>\mathrm{Th} / \mathrm{U})$ occurs in $26 \%$ of measurements. 


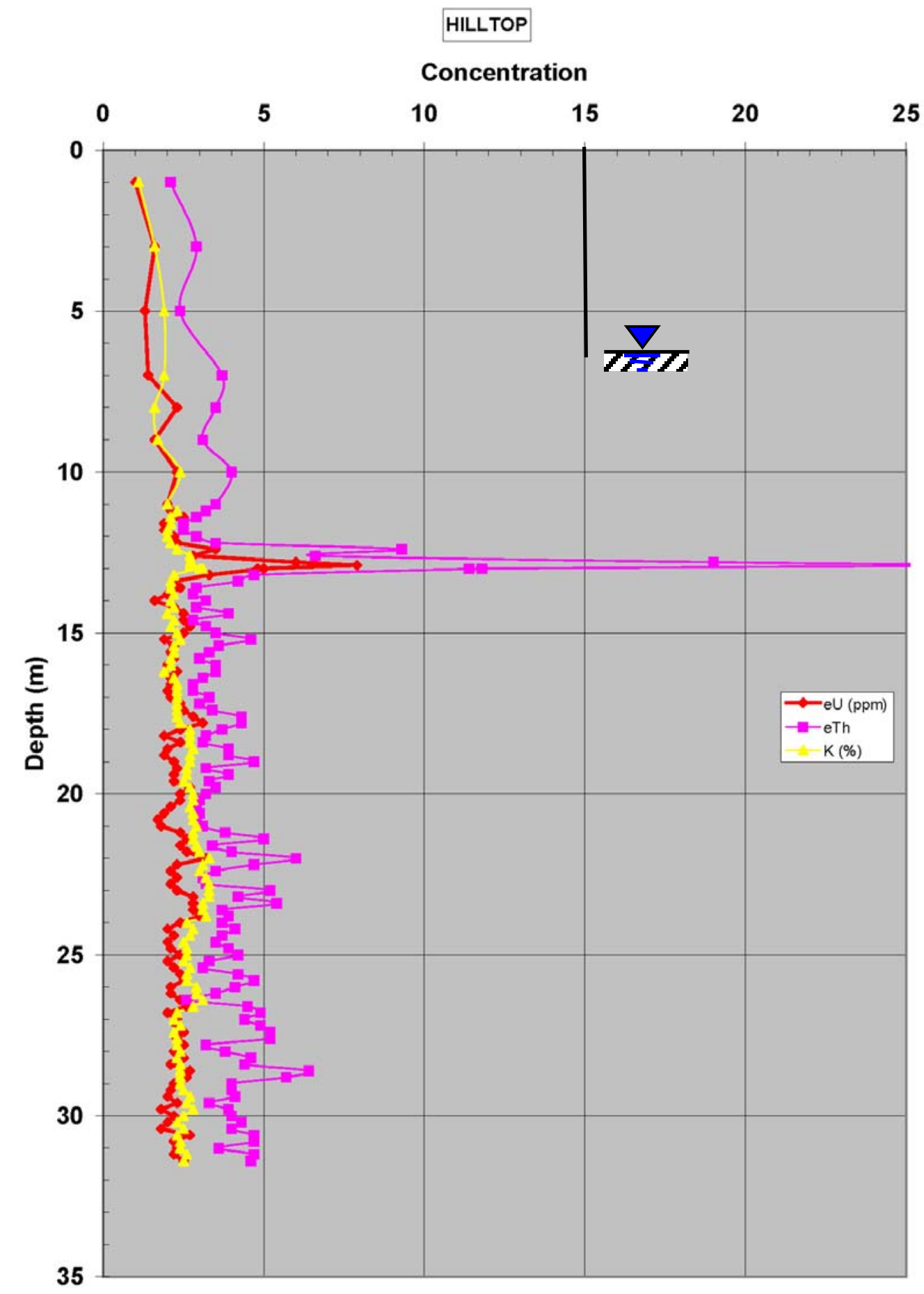

Figure $50 \mathrm{U}$, Th and K curves for the HILLTOP well. This well produces young water with extremely low $\mathrm{U}(0.05 \mathrm{ppb})$. The small $\mathrm{U}$ spike is associated with a large Th spike, potentially indicating a heavy mineral or clay or shale layer. Elevation $300 \mathrm{~m}$ amsl. 


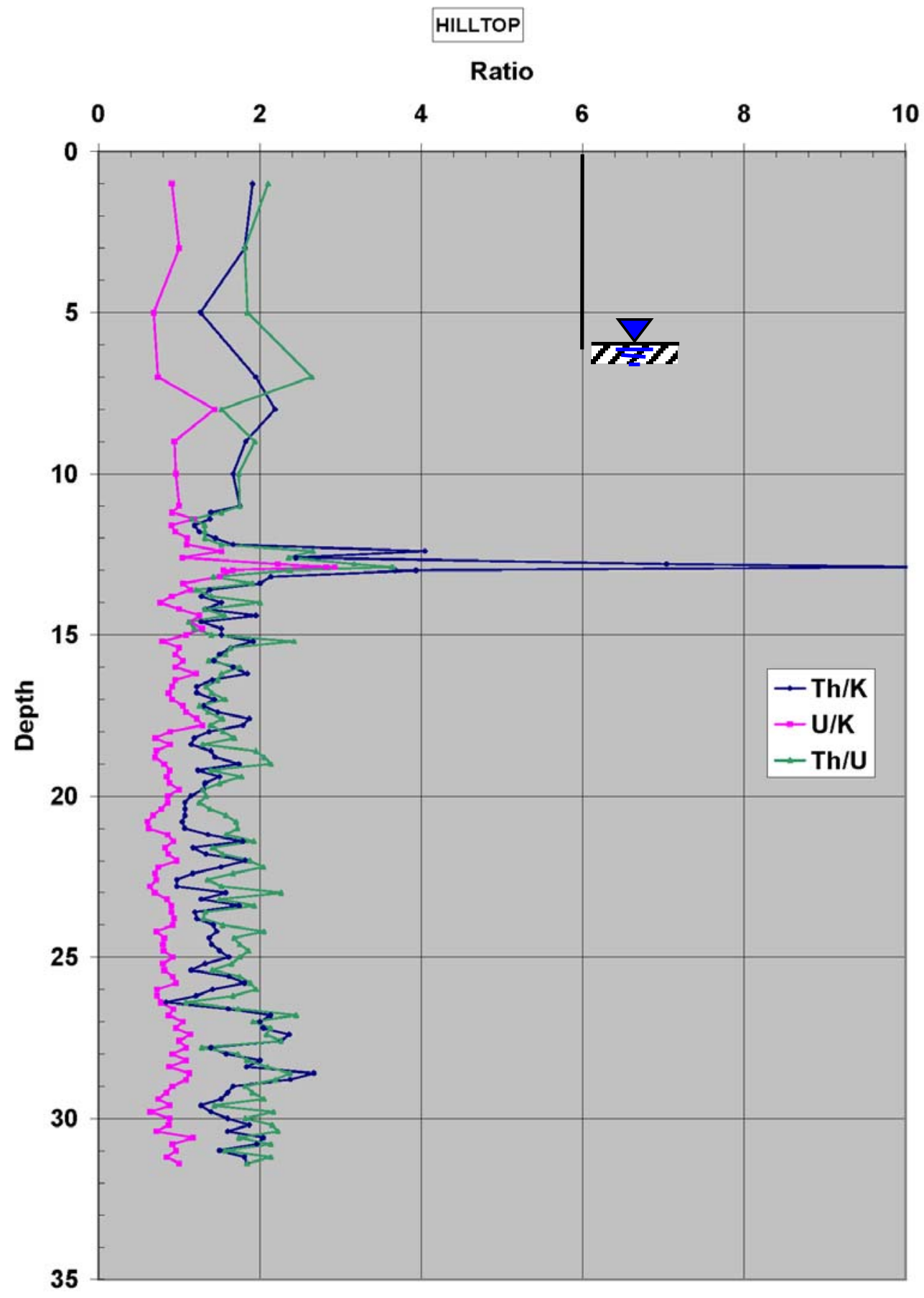

Figure $51 \mathrm{U}$, Th and $\mathrm{K}$ ratio curves for the HILLTOP well. Cross over (U/K > Th/U) occurs in $4 \%$ of measurements. 


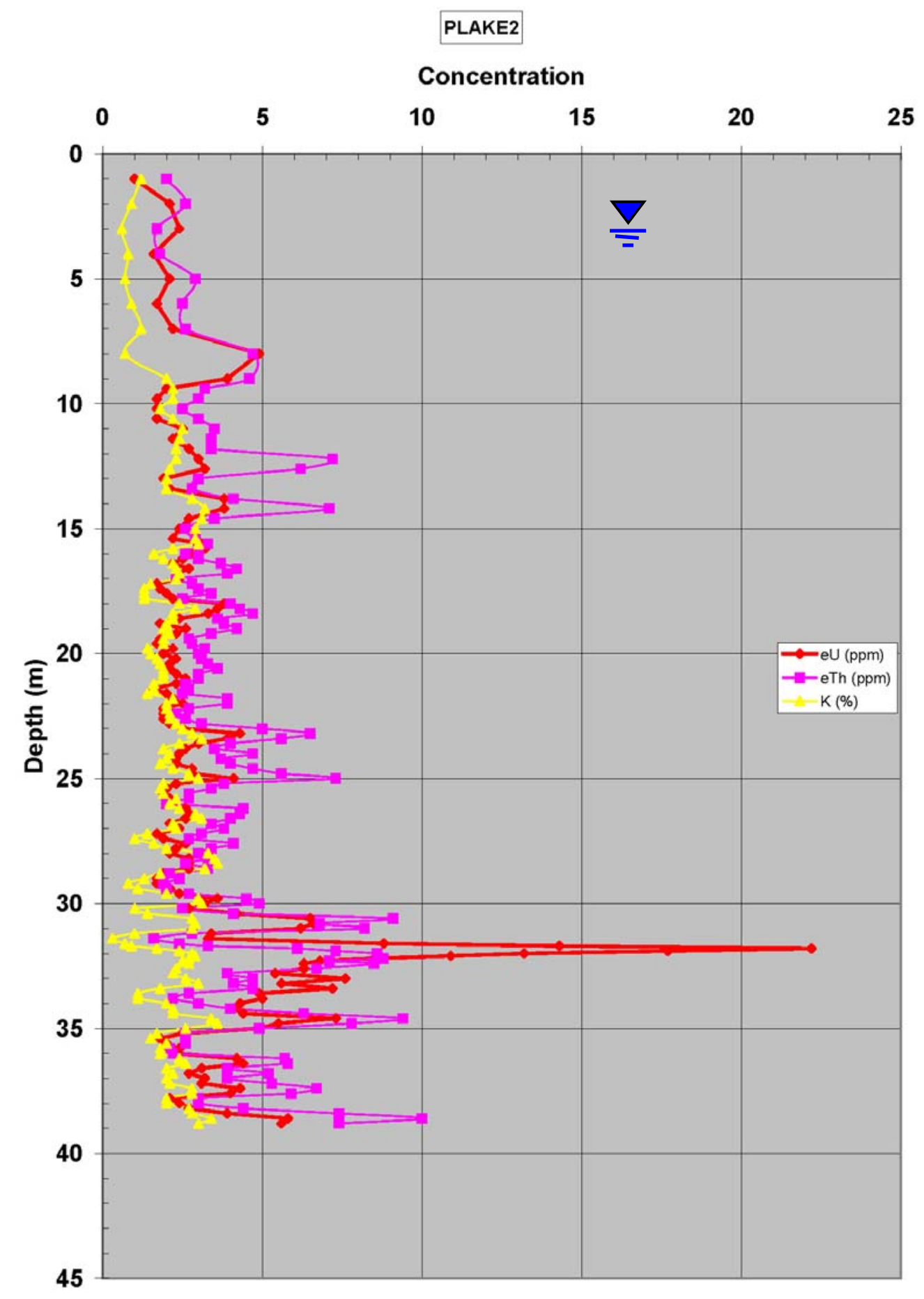

Figure $52 \mathrm{U}$, Th and $\mathrm{K}$ curves for the PLAKE2 well. This well shows a relatively large $\mathrm{U}$ spike and produces old water with about $82 \mathrm{ppb} \mathrm{U}$. The $\mathrm{U}$ spike is not associated with a large Th spike, possibly indicating $U$ enrichment (e.g., carnotite) by groundwater. Elevation $191 \mathrm{~m}$ amsl. 


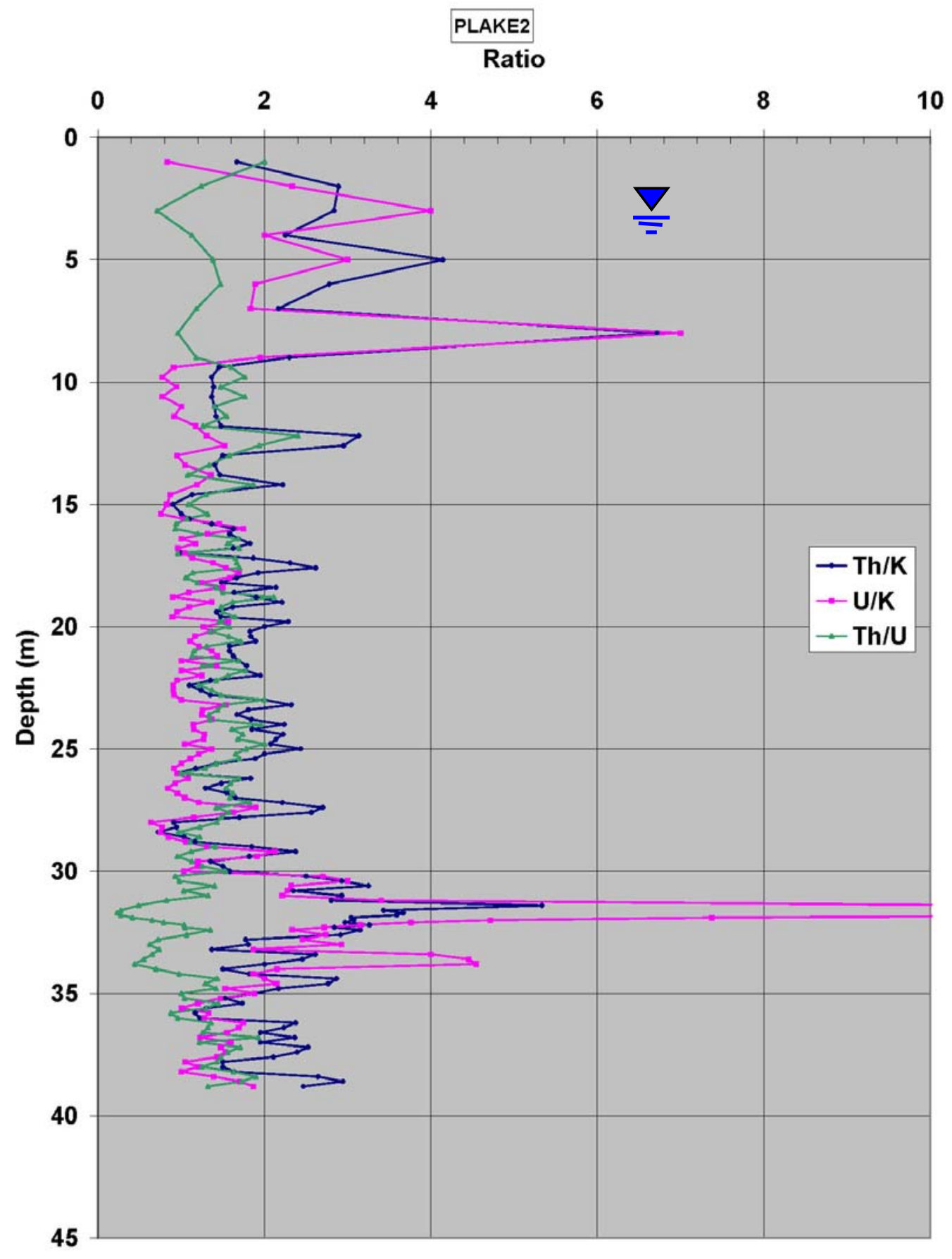

Figure $53 \mathrm{U}$, Th and $\mathrm{K}$ ratio curves for the PLAKE2 well. Note large crossover, indicating $\mathrm{U}$ enrichment relative to Th and $\mathrm{K}$. Cross over (U/K $>\mathrm{Th} / \mathrm{U})$ occurs in $45 \%$ of measurements. 


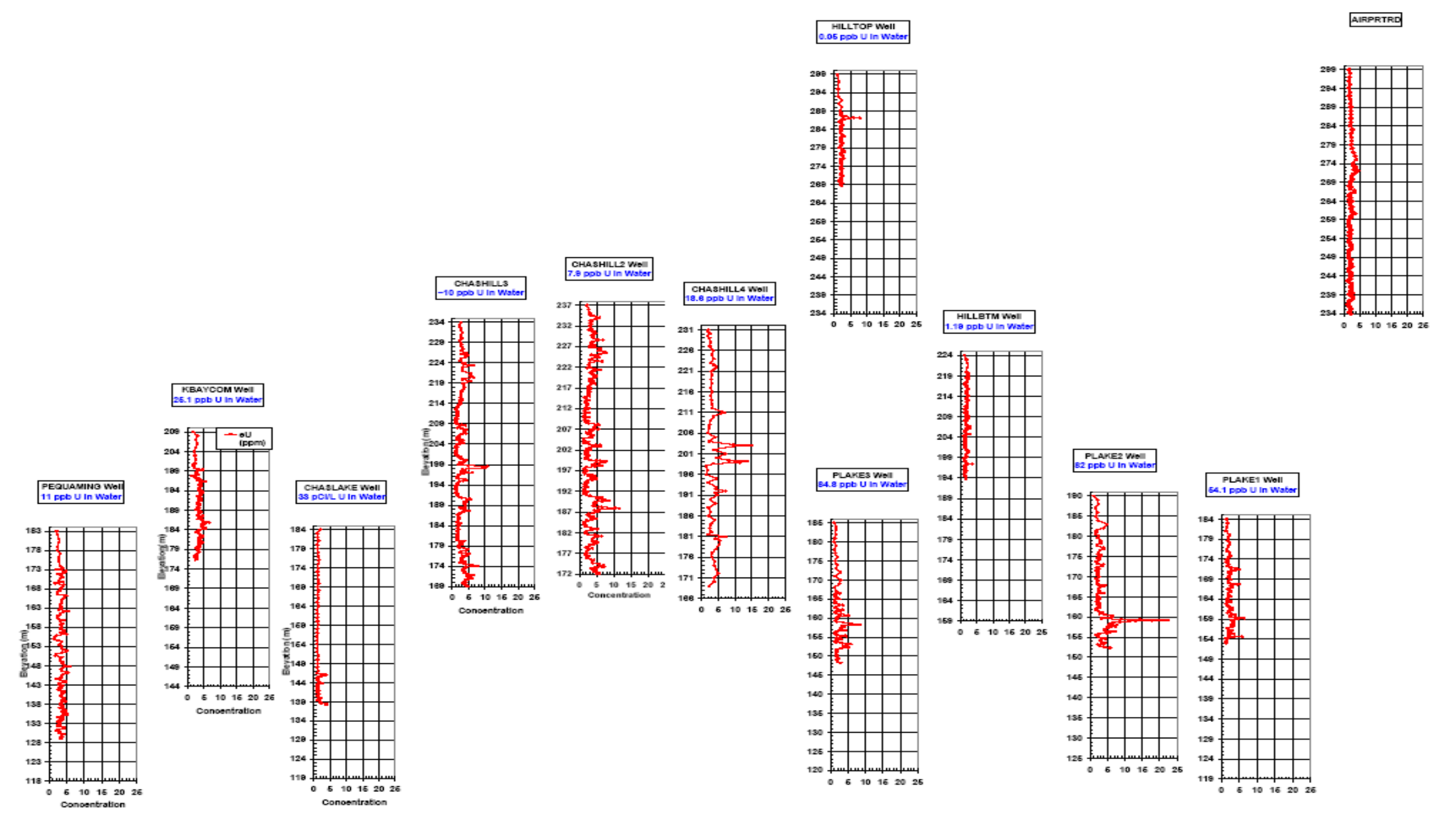

Figure 54 Well $\operatorname{logs}(\mathrm{eU})$ positioned in relation to mean sea level. The three Chassell test wells on the hill are within 200 feet of each other and show good correlation, however these wells do not correlate with the HILLBTM well (2 miles north at same elevation). The Portage Lake wells (PLAKE1, 2, 3) show higher $U$ in the lower portions of their logs at similar elevation. The HILLTOP and AIRPRTRD wells are at the same elevation and both show generally low $\mathrm{U}$, however correlation of wells across the study area is tentative due to sparse data. 


\section{$\mathrm{U}$ and Th Distribution by Grain Size: Average and Range}

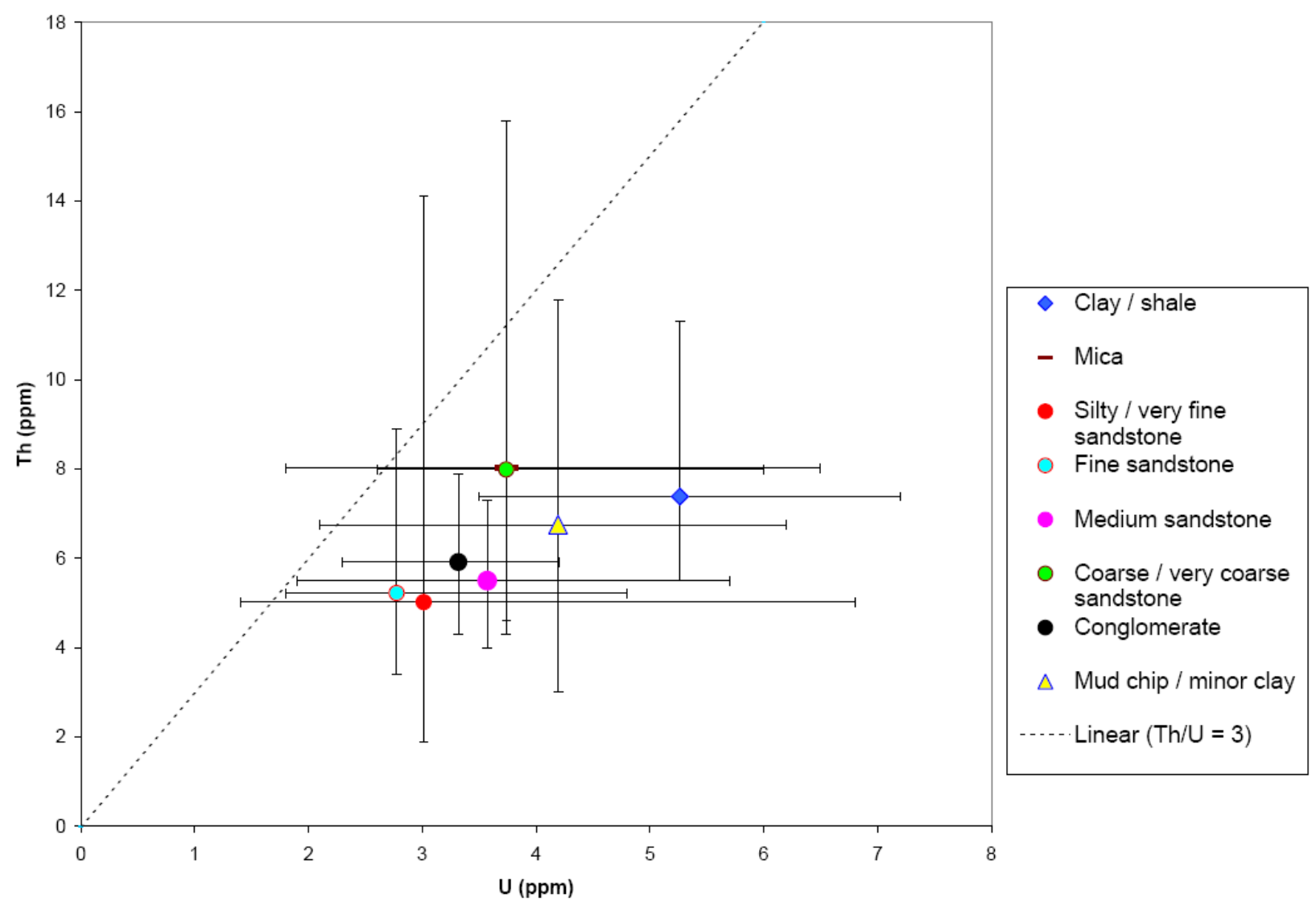

Figure 55 Spectral gamma-ray data from outcrop measurements grouped by grain size. Bars indicate range (minimum and maximum measurements). Clayey/shale samples have the highest average $\mathrm{U}(5.2 \mathrm{ppm})$ followed by sandstones with mud chip rip up clasts and minor clay (4.2 ppm). However all grain sizes produce some readings over $4 \mathrm{ppm}$. Samples with mica have the highest average Th $(8 \mathrm{ppm})$. $\mathrm{Th} / \mathrm{U}$ ratios are generally below 3 , indicating $\mathrm{U}$ enrichment relative to typical source rocks. 


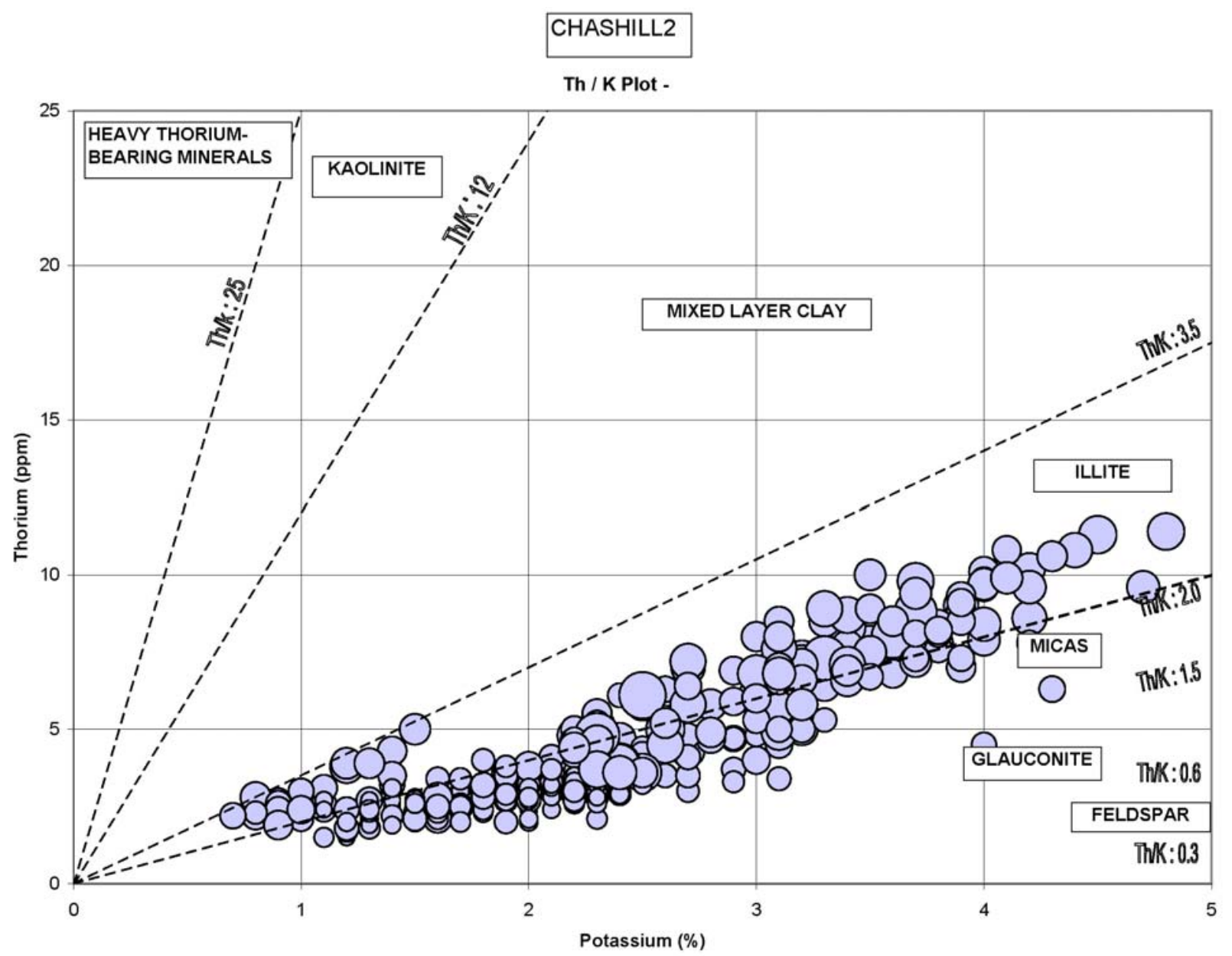

Figure $56 \mathrm{Th} / \mathrm{K}$ plot for the CHASHILL2 well. Th and $\mathrm{K}$ values are derived from spectral gamma-ray logging. Interpretation of illite agrees with XRD analysis of core. 


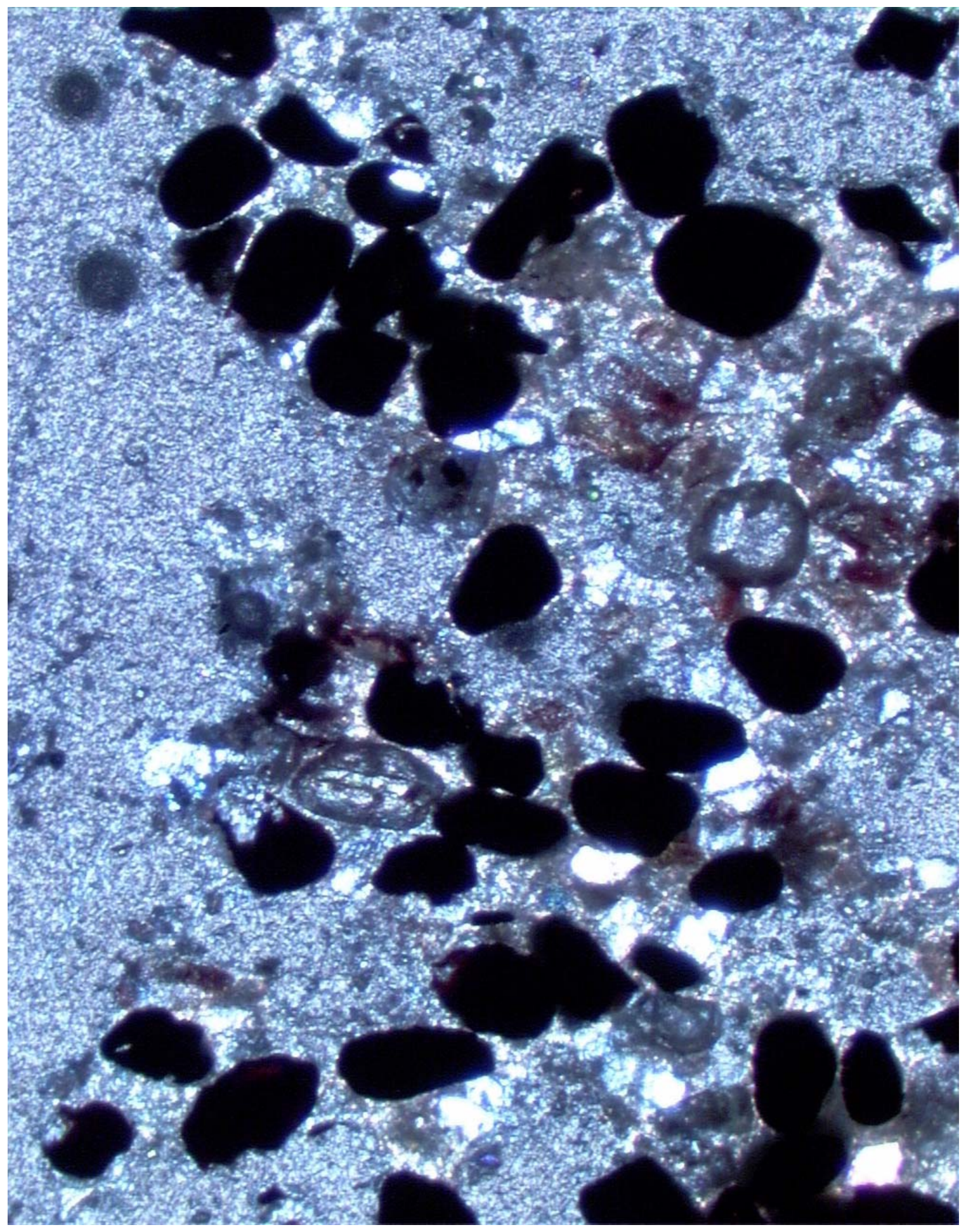

Figure 57 Thin section from the Amoco core (2162.4 ft). Red very fine sandstone with heavy mineral layers. Lab analysis indicates $30 \mathrm{ppm}$ total U. High relief minerals are likely U-bearing zircons (Kramer 2004). Field of view $1.5 \mathrm{~mm}$. 
Table 1 Comparison of Gross Alpha and U Analysis. Several wells with elevated U were identified by existing gross alpha results.

\begin{tabular}{|c|c|c|c|c|}
\hline $\begin{array}{c}\text { Sample } \\
\text { Number }\end{array}$ & $\begin{array}{c}\text { Gross } \\
\text { Alpha } \\
(\mathrm{pCi} / \mathrm{L})\end{array}$ & $\begin{array}{c}\mathrm{U} \\
(\mathrm{ppb})\end{array}$ & ${ }^{234} \mathrm{U} /{ }^{238} \mathrm{U}$ & $\begin{array}{c}\mathrm{U} \\
(\mathrm{pCi} / \mathrm{L})\end{array}$ \\
\hline 4 & 57 & 32.13 & 4.61 & 61 \\
\hline $18 /$ neighbor & 85 & 189.72 & 1.15 & 137 \\
\hline 23 & 22 & 1.19 & 3.21 & 1.68 \\
\hline 1 & 76 & 118.73 & 1.20 & 88 \\
\hline 13 & 47 & 75.17 & 1.62 & 66 \\
\hline 308 & 46 & 27.50 & - & - \\
\hline 178 & 27 & 40.05 & 1.61 & 35 \\
\hline
\end{tabular}

Conversion: $(\mathrm{AR}+1)(\mathrm{ppb})(0.336 \mathrm{pCi} / \mathrm{ppb})$ 
Table 2 Comparison of NURE and U Analysis from this Study. Several areas with elevated U were located based on NURE data.

\begin{tabular}{|c|c|c|c|c|}
\hline $\begin{array}{c}\text { Sample } \\
\text { Number }\end{array}$ & County & Formation & $\begin{array}{c}\text { NURE U } \\
(\mathrm{ppb})\end{array}$ & $\begin{array}{c}\text { LITER U } \\
(\mathrm{ppb})\end{array}$ \\
\hline 136 & Gogebic & Jacobsville Sandstone & 52 & 65 \\
\hline 135 & Gogebic & Jacobsville Sandstone & 35 & 31 \\
\hline 134 & Ontonagon & Freda Sandstone & 224 & 303 \\
\hline 130 & Ontonagon & Freda Sandstone & 36 & 35 \\
\hline 132 & Ontonagon & Freda Sandstone & 77 & 69 \\
\hline
\end{tabular}


Table 3 Comparisons of Multiple Analyses. Results for GW 1 were consistent when sampled in different seasons, by different labs, using different methods.

\begin{tabular}{|c|c|c|c|}
\hline Laboratory & Analysis Method & Sample Collection & $\begin{array}{c}\text { Measured U Concentration } \\
(\mathrm{ppb})\end{array}$ \\
\hline Rad Safe & Radiochemical & Spring 2002 & 110 \\
\hline LITER & ICP-MS & Spring 2002 & 115.02 \\
\hline LITER & ICP-MS & Spring 2002 & 118.73 \\
\hline MIDEQ & ICP-MS & Fall 2003 & 112.2 \\
\hline
\end{tabular}


Table 4 U- and Th-Series Equilibrium Analysis. Gamma Spectroscopy (Bq/g): indicated core samples are in equilibrium, while the outcrop sample was out of equilibrium, probably due to weathering.

\begin{tabular}{|c|c|c|c|}
\hline Series & Grand Island Outcrop & $\begin{array}{c}\text { Amoco Core } \\
(2385-\mathrm{ft} \text { below surface })\end{array}$ & $\begin{array}{c}\text { Amoco Core } \\
\text { (2162.4-ft below surface) }\end{array}$ \\
\hline \multicolumn{4}{|l|}{ U-238 a series: } \\
\hline $\mathrm{U}-238$ & 0.04 & 0.15 & 0.02 \\
\hline Th-234 & $<0.04$ & 0.17 & $<0.04$ \\
\hline Th-230 & $<0.8$ & $<0.8$ & $<0.9$ \\
\hline $\mathrm{Ra}-226$ & 0.10 & 0.18 & 0.05 \\
\hline $\mathrm{Pb}-214$ & 0.12 & 0.15 & 0.04 \\
\hline Bi-214 & 0.12 & 0.16 & 0.03 \\
\hline $\mathrm{Pb}-210$ & $<0.3$ & 0.4 & $<0.4$ \\
\hline \multicolumn{4}{|l|}{ U-235 series: } \\
\hline $\mathrm{U}-235$ & $<0.01$ & $<0.01$ & $<0.01$ \\
\hline Th-227 & $<0.2$ & $<0.03$ & $<0.02$ \\
\hline $\mathrm{Ra}-223$ & $<0.01$ & 0.03 & $<0.01$ \\
\hline Rn-219 & $<0.01$ & $<0.01$ & $<0.01$ \\
\hline $\mathrm{Pb}-211$ & $<0.04$ & $<0.04$ & $<0.06$ \\
\hline \multicolumn{4}{|l|}{ Th-232 series: } \\
\hline Ac-228 & $<0.03$ & 0.20 & $<0.04$ \\
\hline Rn-220 & 0.03 & 0.13 & 0.03 \\
\hline Pb-212 & 0.04 & 0.13 & 0.03 \\
\hline Bi-212 & $<0.06$ & 0.16 & $<0.09$ \\
\hline Th-208 & 0.02 & 0.05 & 0.01 \\
\hline
\end{tabular}

${ }^{a} \mathrm{U}-238$ activity values were calculated from the total $\mathrm{U}(\mathrm{ppm})$ by SLOWPOKE DNC

\begin{tabular}{|l|l|l|l|}
\hline & Grand Island Outcrop & Amoco Core $2385 \mathrm{ft}$ & Amoco Core $2162.4 \mathrm{ft}$ \\
\hline $\mathrm{U}(\mathrm{ppm})$ & 3.6 & 12.4 & 1.8 \\
\hline
\end{tabular}


Table 5 Uranium Species and Saturation Indices for a Well with Elevated U

GW 18 well, part of linear $U$ anomaly along US Hwy 41 near Chassell, MI DEQ Analysis Database file: C:\Program Files\USGS\Phreeqc Interactive 2.8\minteq.dat

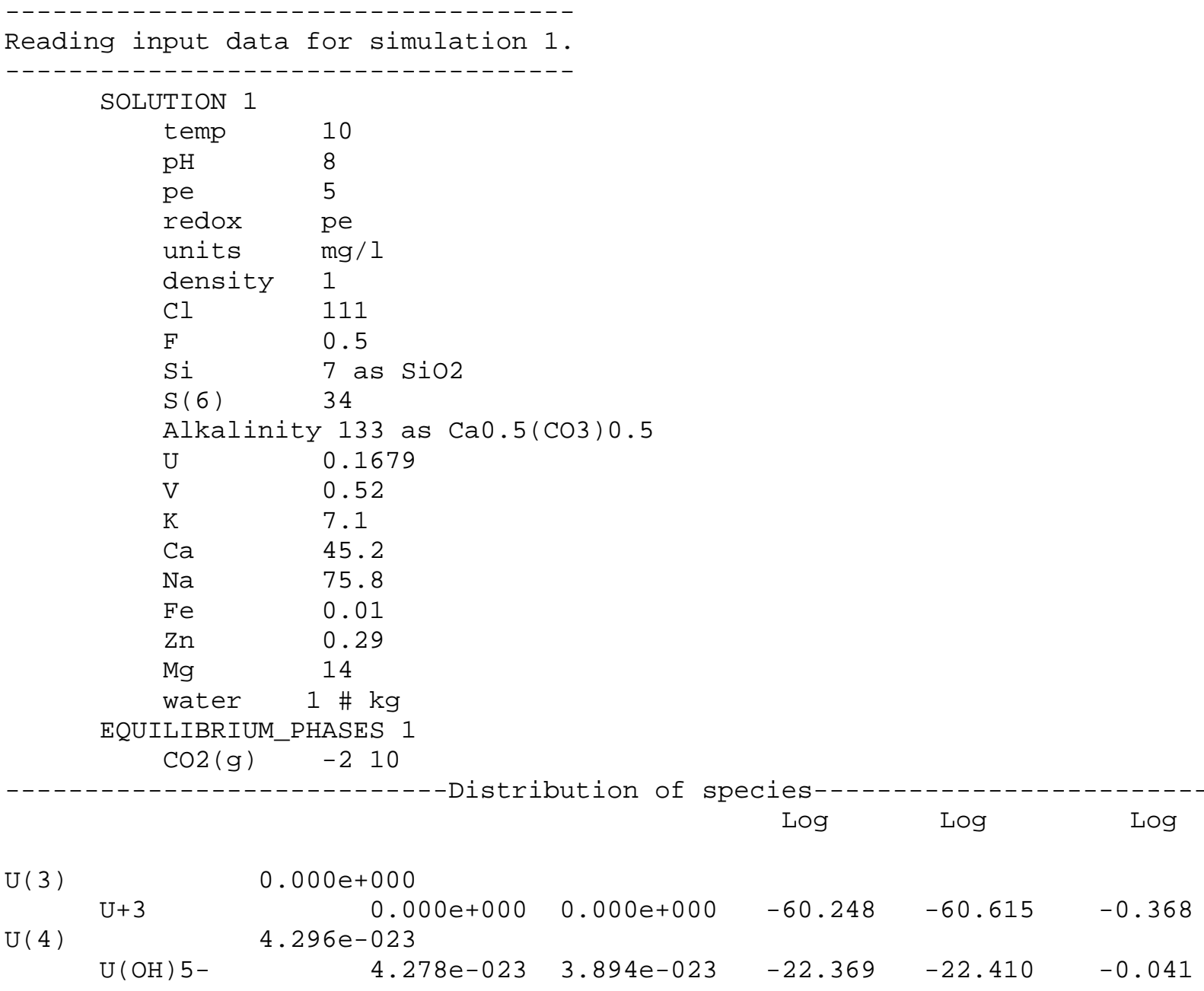

\begin{tabular}{|c|c|c|c|c|c|}
\hline & $\odot . \odot \odot \odot e+\odot \odot \odot$ & & & & \\
\hline $\mathrm{U}+3$ & $\begin{array}{l}\odot . \odot \odot \odot \mathrm{e}+\odot \odot \odot \\
4.296 \mathrm{e}-\odot 23\end{array}$ & $\odot . \odot \odot \odot \mathrm{e}+\odot \odot \odot$ & -60.248 & -60.615 & -0.368 \\
\hline H) 5 - & $4.278 e-023$ & $3.894 \mathrm{e}-023$ & -22.369 & -22.410 & 041 \\
\hline
\end{tabular}




\begin{tabular}{|c|c|c|c|c|c|c|}
\hline & $\mathrm{U}(\mathrm{OH}) 4$ & $1.793 e-025$ & $1.796 \mathrm{e}-025$ & -24.746 & -24.746 & 0.001 \\
\hline & $\mathrm{U}(\mathrm{OH}) 3+$ & $7.465 e-029$ & $6.795 e-029$ & -28.127 & -28.168 & -0.041 \\
\hline & $\mathrm{U}(\mathrm{OH}) 2+2$ & $6.083 e-033$ & $4.175 e-033$ & -32.216 & -32.379 & -0.163 \\
\hline & $\mathrm{UOH}+3$ & $6.155 e-038$ & $2.640 \mathrm{e}-038$ & -37.211 & -37.578 & $-\odot .368$ \\
\hline & UF $2+2$ & $3.341 e-039$ & $2.294 \mathrm{e}-039$ & -38.476 & -38.639 & $-\odot .163$ \\
\hline & UF3+ & $2.696 \mathrm{e}-039$ & $2.454 \mathrm{e}-039$ & -38.569 & -38.610 & $-\odot .041$ \\
\hline & UF4 & $2.411 \mathrm{e}-039$ & $2.416 \mathrm{e}-039$ & -38.618 & -38.617 & 0.001 \\
\hline & $U F+3$ & $4.409 \mathrm{e}-04 \odot$ & $1.891 \mathrm{e}-04 \odot$ & -39.356 & -39.723 & -0.368 \\
\hline & $\mathrm{U}(\mathrm{S} 04) 2$ & $\odot . \odot \odot \odot e+\odot \odot \odot$ & $\odot . \odot \odot \odot e+\odot \odot \odot$ & -41.452 & -41.451 & 0.001 \\
\hline & UF5 - & $\odot . \odot \odot \odot \mathrm{e}+\odot \odot \odot$ & $\odot . \odot \odot \odot \mathrm{e}+\odot \odot \odot$ & -41.618 & -41.659 & $-\odot .041$ \\
\hline & US04+2 & $\odot . \odot \odot \odot \mathrm{e}+\odot \odot \odot$ & $\odot . \odot \odot \odot e+\odot \odot \odot$ & -41.749 & -41.913 & $-\odot .163$ \\
\hline & $\mathrm{U}+4$ & $\odot . \odot \odot \odot \mathrm{e}+\odot \odot \odot$ & $\odot . \odot \odot \odot e+\odot \odot \odot$ & $-42.9 \odot 2$ & -43.555 & $-\odot .654$ \\
\hline & UF6-2 & $\odot . \odot \odot \odot \mathrm{e}+\odot \odot \odot$ & $\odot . \odot \odot \odot e+\odot \odot \odot$ & -43.586 & -43.750 & -0.163 \\
\hline & $\mathrm{UCl}+3$ & $\odot .000 \mathrm{e}+0 \odot \odot$ & $\odot .00 \odot \mathrm{e}+\odot \odot \odot$ & -44.782 & -45.149 & -0.368 \\
\hline & $\mathrm{U} 6(\mathrm{OH}) 15+9$ & $\odot . \odot \odot \odot e+\odot \odot \odot$ & $\odot . \odot \odot \odot e+\odot \odot \odot$ & -169.244 & -172.552 & -3.308 \\
\hline$U(5)$ & 2.7 & -016 & & & & \\
\hline & U02+ & $2.700 \mathrm{e}-016$ & $2.458 e-016$ & -15.569 & -15.609 & -0.041 \\
\hline $\mathrm{U}(6)$ & 7.0 & -007 & & & & \\
\hline & U02 ( $\mathrm{CO} 3) 2-2$ & $5.293 e-0 \odot 7$ & $3.633 e-007$ & -6.276 & -6.440 & $-\odot .163$ \\
\hline & $\mathrm{U} 02(\mathrm{CO} 3) 3-4$ & $1.083 e-007$ & $2.405 e-008$ & -6.965 & -7.619 & -0.654 \\
\hline & $\mathrm{U} 02 \mathrm{CO} 3$ & $6.776 \mathrm{e}-\odot \odot 8$ & $6.789 \mathrm{e}-0 \odot 8$ & -7.169 & -7.168 & 0.001 \\
\hline & $\mathrm{U} 02 \mathrm{OH}+$ & $2.601 \mathrm{e}-010$ & $2.368 e-010$ & -9.585 & -9.626 & $-\odot .041$ \\
\hline & U02H3Si04+ & $3.708 e-011$ & $3.375 e-011$ & -10.431 & -10.472 & $-\odot .041$ \\
\hline & U02F+ & $2.120 \mathrm{e}-011$ & $1.930 \mathrm{e}-011$ & -10.674 & -10.714 & $-\odot .041$ \\
\hline & $\mathrm{U} 02+2$ & $9.060 \mathrm{e}-012$ & $6.219 e-012$ & -11.043 & -11.206 & $-\odot .163$ \\
\hline & U02F2 & $3.065 e-012$ & $3.071 e-012$ & -11.514 & -11.513 & $\odot .001$ \\
\hline & U02S04 & $4.259 e-013$ & $4.267 e-013$ & -12.371 & -12.370 & 0.001 \\
\hline & U02Cl+ & $2.887 e-014$ & $2.628 e-014$ & -13.540 & -13.580 & -0.041 \\
\hline & U02F3- & $2.185 e-014$ & $1.989 e-014$ & -13.660 & -13.701 & $-\odot .041$ \\
\hline & $(\mathrm{UO2}) 2(\mathrm{OH}) 2+2$ & $6.971 \mathrm{e}-015$ & $4.785 e-015$ & -14.157 & -14.320 & $-\odot .163$ \\
\hline & U02(S04)2-2 & $3.582 e-015$ & $2.459 \mathrm{e}-015$ & -14.446 & -14.609 & $-\odot .163$ \\
\hline & $(\mathrm{U} 02) 3(\mathrm{OH}) 5+$ & $1.556 \mathrm{e}-015$ & $1.416 \mathrm{e}-015$ & -14.808 & -14.849 & $-\odot .041$ \\
\hline & U02F4-2 & $1.214 \mathrm{e}-017$ & $8.331 e-018$ & -16.916 & -17.079 & -0.163 \\
\hline
\end{tabular}

Phase

SI $\log$ IAP $\log$ KT 


\begin{tabular}{|c|c|c|c|c|}
\hline Akerminite & -25.55 & 24.89 & 50.44 & Ca2MgSi207 \\
\hline Anhydrite & -2.30 & -6.79 & -4.49 & CaSo4 \\
\hline Aragonite & -0.91 & -9.16 & -8.26 & CaC03 \\
\hline Artinite & -9.45 & 1.27 & 10.72 & $\mathrm{MgC0} 3: \mathrm{Mg}(\mathrm{OH}) 2: 3 \mathrm{H} 20$ \\
\hline B_U02 $(\mathrm{OH}) 2$ & -3.15 & 2.93 & 6.08 & $\mathrm{U} 02(\mathrm{OH}) 2$ \\
\hline Bianchite & -7.54 & -9.30 & -1.76 & ZnS0 $4: 6 \mathrm{H} 20$ \\
\hline Brucite & -7.07 & 10.72 & 17.80 & $\mathrm{Mg}(\mathrm{OH}) 2$ \\
\hline Ca-Olivine & -21.67 & 18.10 & 39.77 & Ca2Si04 \\
\hline Ca2V207 & -3.79 & 5.70 & 9.49 & Cav03.5 \\
\hline Ca3(V04) 2 & -9.64 & 11.20 & 20.84 & Ca1. 5V04 \\
\hline Ca3Si05 & -48.88 & 29.12 & 78.00 & Ca3Si05 \\
\hline Ca_Vanadate & -3.04 & 0.19 & 3.22 & $\mathrm{CaO} .5 \mathrm{VO} 3$ \\
\hline Calcite & -0.76 & -9.16 & -8.41 & CaC03 \\
\hline Carnotite & 0.32 & 0.89 & 0.57 & KU02V04 \\
\hline $\mathrm{CH} 4(\mathrm{~g})$ & -92.78 & -135.25 & -42.47 & $\mathrm{CH} 4$ \\
\hline Chalcedony & -0.23 & -3.93 & -3.70 & $\mathrm{SiO} 2$ \\
\hline Chrysotile & -9.92 & 24.31 & 34.23 & $\operatorname{Mg} 3 S i 205(\mathrm{OH}) 4$ \\
\hline Clinoenstatite & -5.32 & 6.79 & 12.12 & MgSi03 \\
\hline $\operatorname{co2}(\mathrm{g})$ & -2.00 & -20.18 & -18.18 & $\mathrm{CO} 2$ \\
\hline Cristobalite & -0.13 & -3.93 & -3.80 & $\mathrm{SiO} 2$ \\
\hline Diopside & -7.26 & 13.88 & 21.14 & CaMgSi206 \\
\hline Dolomite & -1.94 & -18.62 & -16.68 & $\mathrm{CaMg}(\mathrm{CO} 3) 2$ \\
\hline Epsomite & -4.84 & -7.09 & -2.25 & MgSO $4: 7 \mathrm{H} 20$ \\
\hline $\mathrm{Fe}(\mathrm{OH}) 2.7 \mathrm{Cl} 0.3$ & 6.05 & 16.43 & 10.38 & $\mathrm{Fe}(\mathrm{OH}) 2.7 \mathrm{Cl} 10.3$ \\
\hline $\mathrm{Fe} 2(\mathrm{SO} 4) 3$ & -47.52 & -14.80 & 32.72 & $\mathrm{Fe} 2(\mathrm{SO} 4) 3$ \\
\hline $\mathrm{Fe} 3(\mathrm{OH}) 8$ & -3.51 & 43.55 & 47.06 & $\mathrm{Fe} 3(\mathrm{OH}) 8$ \\
\hline Fe_Vanadate & -1.28 & -2.86 & -1.57 & $\mathrm{Fe} 0.5 \mathrm{VO} 3$ \\
\hline Ferrihydrite & 1.00 & 19.31 & 18.31 & $\mathrm{Fe}(\mathrm{OH}) 3$ \\
\hline Fes(ppt) & -88.04 & -127.95 & -39.91 & FeS \\
\hline Fluorite & -1.58 & -12.38 & -10.80 & CaF2 \\
\hline Forsterite & -12.67 & 17.52 & 30.18 & Mg2SiO4 \\
\hline Goethite & 4.83 & 19.31 & 14.48 & $\mathrm{FeOOH}$ \\
\hline Goslarite & -7.21 & -9.30 & -2.09 & ZnS04: 7H20 \\
\hline Greenalite & -13.89 & 6.92 & 20.81 & Fe3Si205(OH 4 \\
\hline Greigite & -325.79 & -487.96 & -162.18 & Fe3S4 \\
\hline Gummite & -8.37 & 2.93 & 11.30 & U03 \\
\hline Gypsum & -1.94 & -6.79 & -4.86 & CaSO4:2H2O \\
\hline Halite & -6.62 & -5.07 & 1.55 & $\mathrm{NaCl}$ \\
\hline
\end{tabular}




\begin{tabular}{|c|c|c|c|c|}
\hline Hematite & 14.59 & 38.62 & 24.03 & Fe203 \\
\hline Huntite & -8.56 & -37.53 & -28.97 & CaMg3( CO3) 4 \\
\hline Hydromagnesite & -20.36 & -27.10 & -6.74 & $\operatorname{Mg} 5(\mathrm{CO} 3) 4(\mathrm{OH}) 2: 4 \mathrm{H} 20$ \\
\hline Jarosite-H & -7.99 & 22.32 & 30.30 & $(\mathrm{H} 30) \mathrm{Fe} 3(\mathrm{SO} 4) 2(\mathrm{OH}) 6$ \\
\hline Jarosite-K & -1.07 & 25.60 & 26.68 & $\mathrm{KFe} 3(\mathrm{SO} 4) 2(\mathrm{OH}) 6$ \\
\hline Jarosite-Na & -3.60 & 26.86 & 30.47 & $\mathrm{NaFe} 3(\mathrm{SO} 4) 2(\mathrm{OH}) 6$ \\
\hline Larnite & -23.26 & 18.10 & 41.36 & Ca2SiO4 \\
\hline Lepidocrocite & 4.52 & 19.31 & 14.79 & $\mathrm{FeOOH}$ \\
\hline Lime & -23.58 & 11.02 & 34.59 & $\mathrm{CaO}$ \\
\hline Mackinawite & -87.31 & -127.95 & -40.64 & FeS \\
\hline Magadiite & -8.69 & -22.99 & -14.30 & NaSi7013(OH) $3: 3 \mathrm{H} 20$ \\
\hline Maghemite & 5.40 & 38.62 & 33.23 & Fe203 \\
\hline Magnesite & -1.67 & -9.46 & -7.79 & $\mathrm{MgC03}$ \\
\hline Magnetite & 11.01 & 43.55 & 32.54 & Fe304 \\
\hline Melanterite & -10.30 & -12.88 & -2.58 & FeSO $4: 7 \mathrm{H} 20$ \\
\hline Merwinite & -36.79 & 35.91 & 72.70 & Ca3MgSi208 \\
\hline Mg-Ferrite & 3.16 & 49.35 & 46.19 & MgFe204 \\
\hline Mg2V207 & -8.96 & 5.40 & 14.36 & MgV03. 5 \\
\hline Mg_Vanadate & -6.23 & 0.04 & 6.27 & Mg०. . VV03 \\
\hline Mirabilite & -6.87 & -8.72 & -1.85 & $\mathrm{Na} 2 \mathrm{SO} 4: 10 \mathrm{H} 2 \mathrm{O}$ \\
\hline Monticellite & -14.38 & 17.81 & 32.19 & CaMgSi04 \\
\hline Na3V04 & -30.35 & 8.31 & 38.66 & Na3V04 \\
\hline Na4V207 & -15.86 & 3.77 & 19.63 & Na2V03. 5 \\
\hline Na_Vanadate & -4.76 & -0.78 & 3.98 & NaV03 \\
\hline Natron & -9.17 & -11.09 & -1.92 & $\mathrm{Na} 2 \mathrm{C} 03: 10 \mathrm{H} 20$ \\
\hline Nesquehonite & -4.06 & -9.46 & -5.40 & $\mathrm{MgC0} 3: 3 \mathrm{H} 20$ \\
\hline $02(\mathrm{~g})$ & -30.78 & 57.53 & 88.32 & 02 \\
\hline P-Wollstanite & -7.58 & $7 . \odot 8$ & 14.66 & CaSi03 \\
\hline Periclase & -12.19 & 10.72 & 22.91 & MgO \\
\hline Portlandite & -12.85 & 11.02 & 23.87 & $\mathrm{Ca}(\mathrm{OH}) 2$ \\
\hline Pyrite & -141.15 & -232.06 & -90.91 & FeS2 \\
\hline Quartz & 0.31 & -3.93 & -4.25 & Si02 \\
\hline Rutherfordine & -2.81 & -17.25 & -14.45 & U02C03 \\
\hline Schoepite & -2.94 & 2.93 & 5.87 & U02(OH) $2: \mathrm{H} 20$ \\
\hline Sepiolite(a) & -9.13 & 9.65 & 18.78 & Mg2Si307.5OH: 3H2O \\
\hline Sepiolite(c) & -7.32 & 9.65 & 16.97 & Mg2Si307.5OH: 3H2O \\
\hline Siderite & -4.91 & -15.25 & -10.34 & $\mathrm{FeC03}$ \\
\hline $\operatorname{Si02(a)}$ & -0.74 & -3.93 & -3.19 & Si02 \\
\hline
\end{tabular}




\begin{tabular}{|c|c|c|c|c|}
\hline Si02(am) & -1.07 & -3.93 & -2.86 & Si02 \\
\hline Smithsonite & -1.84 & -11.67 & -9.83 & ZnC03 \\
\hline Sphalerite & -76.44 & -124.37 & -47.93 & $\mathrm{ZnS}$ \\
\hline SULFUR & -66.17 & -104.11 & -37.94 & $\mathrm{~S}$ \\
\hline Talc & -7.97 & 16.44 & 24.41 & $\operatorname{Mg} 3 S i 4010(\mathrm{OH}) 2$ \\
\hline Thenardite & -8.56 & -8.72 & -0.16 & $\mathrm{Na} 2 \mathrm{SO}_{4}$ \\
\hline Thermonatrite & -11.33 & -11.09 & 0.23 & $\mathrm{Na} 2 \mathrm{CO} 3: \mathrm{H} 2 \mathrm{O}$ \\
\hline Tremolite & -16.10 & 44.19 & 60.30 & Ca2Mg5Si8022(OH)2 \\
\hline Tyuyamunite & 0.37 & 3.12 & 2.75 & $\mathrm{CaO} .5 \mathrm{U} 02 \mathrm{VO} 4$ \\
\hline U308(C) & -13.94 & -19.98 & -6.05 & U308 \\
\hline U409(C) & -32.92 & -74.59 & -41.66 & U409 \\
\hline UF4 (C) & -44.21 & -72.63 & -28.43 & UF4 \\
\hline UF $4: 2.5 \mathrm{H} 2 \mathrm{O}$ & -34.53 & -72.63 & -38.10 & UF4 : $2.5 \mathrm{H} 20$ \\
\hline u02 ( am) & -17.24 & -25.84 & -8.60 & U02 \\
\hline U03(C) & -5.54 & 2.93 & 8.47 & U03 \\
\hline Uraninite & -11.31 & -25.84 & -14.53 & U02 \\
\hline Uranophane & -8.48 & 9.01 & 17.49 & $\mathrm{Ca}(\mathrm{U} 02) 2(\mathrm{SiO} 0 \mathrm{OH}) 2$ \\
\hline USi04(C) & -12.16 & -29.77 & -17.61 & USi04 \\
\hline $\mathrm{V}(\mathrm{OH}) 3$ & -17.41 & -34.09 & -16.68 & $\mathrm{~V}(\mathrm{OH}) 3$ \\
\hline V203 & -15.43 & -34.09 & -18.66 & V01. 5 \\
\hline V204 & -6.45 & -19.70 & -13.25 & V02 \\
\hline V205 & -4.76 & -5.32 & -0.56 & V02. 5 \\
\hline V305 & -36.46 & -87.88 & -51.42 & V305 \\
\hline V407 & -43.97 & -107.58 & -63.61 & V407 \\
\hline V6013 & -26.08 & -89.46 & -63.38 & V6013 \\
\hline VCl2 & -62.73 & -67.70 & -4.97 & VCl2 \\
\hline vcl3 & -62.04 & -62.93 & -0.89 & VCl3 \\
\hline VF4 & -65.21 & -66.50 & -1.29 & VF4 \\
\hline VMetal & -97.70 & -77.24 & 20.46 & $\mathrm{~V}$ \\
\hline VO & -38.31 & -48.47 & -10.16 & Vo \\
\hline $\mathrm{VO}(\mathrm{OH}) 2$ & -7.49 & -19.70 & -12.22 & $\mathrm{VO}(\mathrm{OH}) 2$ \\
\hline V02Cl & -18.12 & -14.93 & 3.18 & V02Cl \\
\hline VOCl & -29.80 & -43.70 & -13.90 & VOCl \\
\hline Vocl2 & -34.75 & -38.93 & -4.18 & vocl2 \\
\hline $\operatorname{Vos04}(\mathrm{C})$ & -23.82 & -37.51 & -13.69 & V0SO4 \\
\hline Willemite & -3.54 & 13.08 & 16.63 & Zn2SiO4 \\
\hline Wollastonite & -6.67 & 7.08 & 13.75 & CaSi03 \\
\hline Wurtzite & -78.50 & -124.37 & -45.87 & $\mathrm{ZnS}$ \\
\hline
\end{tabular}




\begin{tabular}{|c|c|c|c|c|}
\hline Zincite & -3.48 & 8.51 & 11.99 & Zno \\
\hline Zincosite & -13.06 & -9.30 & 3.76 & ZnS04 \\
\hline $\mathrm{Zn}(\mathrm{OH}) 2(\mathrm{~A})$ & -3.94 & 8.51 & 12.45 & $\mathrm{Zn}(\mathrm{OH}) 2$ \\
\hline $\mathrm{Zn}(\mathrm{OH}) 2(\mathrm{~B})$ & -3.24 & 8.51 & 11.75 & $\mathrm{Zn}(\mathrm{OH}) 2$ \\
\hline $\mathrm{Zn}(\mathrm{OH}) 2(\mathrm{C})$ & -3.69 & 8.51 & 12.20 & $\mathrm{Zn}(\mathrm{OH}) 2$ \\
\hline $\mathrm{Zn}(\mathrm{OH}) 2(\mathrm{E})$ & -2.99 & 8.51 & 11.50 & $\mathrm{Zn}(\mathrm{OH}) 2$ \\
\hline $\mathrm{Zn}(\mathrm{OH}) 2(\mathrm{G})$ & -3.20 & 8.51 & 11.71 & $\mathrm{Zn}(\mathrm{OH}) 2$ \\
\hline $\mathrm{Zn} 2(\mathrm{OH}) 2 \mathrm{SO} 4$ & -8.30 & -0.80 & 7.50 & $\mathrm{Zn} 2(\mathrm{OH}) 2 \mathrm{SO} 4$ \\
\hline $\mathrm{Zn} 2(\mathrm{OH}) 3 \mathrm{Cl}$ & -7.80 & 7.40 & 15.20 & $\mathrm{Zn} 2(\mathrm{OH}) 3 \mathrm{Cl}$ \\
\hline Zn30(s04) 2 & -31.53 & -10.10 & 21.43 & $\mathrm{Zn} 30(\mathrm{SO} 4) 2$ \\
\hline $\mathrm{Zn} 4(\mathrm{OH}) 6 \mathrm{SO} 4$ & -12.18 & 16.22 & 28.40 & $\mathrm{Zn} 4(\mathrm{OH}) 6 \mathrm{~S} 04$ \\
\hline $\mathrm{Zn} 5(\mathrm{OH}) 8 \mathrm{Cl} 2$ & -15.19 & 23.31 & 38.50 & $\mathrm{Zn} 5(\mathrm{OH}) 8 \mathrm{Cl} 2$ \\
\hline Zncl2 & -18.43 & -10.72 & 7.71 & $\mathrm{ZnCl} 2$ \\
\hline $\mathrm{ZnC03:H2O}$ & -1.41 & -11.67 & -10.26 & ZnC03: H2O \\
\hline ZnF2 & -13.88 & -14.89 & -1.01 & $\mathrm{ZnF2}$ \\
\hline ZnMetal & -47.45 & -20.26 & 27.19 & $\mathrm{Zn}$ \\
\hline Zno(Active) & -2.80 & 8.51 & 11.31 & Zno \\
\hline $\operatorname{ZnS}(A)$ & -79.18 & -124.37 & -45.19 & ZnS \\
\hline ZnSi03 & 0.93 & 4.57 & 3.64 & ZnSi03 \\
\hline ZnS04:H20 & -9.15 & -9.30 & -0.16 & ZnSO4:H2O \\
\hline
\end{tabular}


Table 6 Uranium Species and Saturation Indices for a Well with Low U.

GW 49 well, near groundwater divide on Paradise Rd, Houghton, MI DEQ Analysis Database file: C:\Program Files\USGS\Phreeqc Interactive 2.8\minteq.dat

-

Reading input data for

SOLUTION 1

temp $\quad 10$

$\mathrm{pH} \quad 6.6$

pe $\quad 9.32$

redox pe

units $\quad \mathrm{mg} / \mathrm{l}$

density 1

$\begin{array}{ll}\mathrm{F} & 0.3 \\ \mathrm{P} & 0.7\end{array}$

Si $\quad 13$ as $\mathrm{SiO2}$

$\mathrm{S}(6) \quad 7$

Alkalinity 26 as $\mathrm{CaO} .5(\mathrm{CO}) 0.5$

$\mathrm{U} \quad 0.01 \mathrm{ug} / \mathrm{l}$

$\mathrm{Ca} \quad 14.9$

Mg $\quad 0.9$

$\begin{array}{lll}\mathrm{K} & 0.9\end{array}$

$\mathrm{Na} \quad 1.3$

$\begin{array}{lll}\mathrm{Cu} & 0.1\end{array}$

water 1 \# kg

EQUILIBRIUM_PHASES 1 $\mathrm{CO} 2(\mathrm{~g}) \quad-210$

\begin{tabular}{|c|c|c|c|c|c|c|}
\hline \multirow[b]{2}{*}{$U(3)$} & \multicolumn{3}{|c|}{$\odot . \odot \odot \odot e+\odot \odot \odot$} & $\log$ & $\log$ & $\log$ \\
\hline & & +000 & & & & \\
\hline \multirow[t]{4}{*}{$\mathrm{U}(4)$} & $U+3$ & $\begin{array}{l}\odot . \odot \odot \odot e+\odot \odot \odot ~ \\
-\odot 34\end{array}$ & $\odot . \odot \odot \odot e+\odot \odot \odot$ & -70.555 & -70.708 & -0.152 \\
\hline & $\mathrm{U}(\mathrm{OH}) 5-$ & $1.630 \mathrm{e}-034$ & $1.568 \mathrm{e}-034$ & -33.788 & -33.805 & -0.017 \\
\hline & U(HPO4) 4- 4 & $8.460 \mathrm{e}-035$ & $4.539 e-035$ & -34.073 & -34.343 & -0.270 \\
\hline & $\mathrm{U}(\mathrm{OH}) 4$ & $3.464 e-036$ & $3.465 e-036$ & -35.460 & -35.460 & $\odot .0 \odot \odot$ \\
\hline
\end{tabular}




\begin{tabular}{|c|c|c|c|c|c|c|}
\hline & $\mathrm{U}(\mathrm{HPO} 4) 3-2$ & $1.433 e-038$ & $1.226 e-038$ & -37.844 & -37.911 & -0.068 \\
\hline & $\mathrm{U}(\mathrm{OH}) 3+$ & $6.531 e-039$ & $6.282 \mathrm{e}-039$ & -38.185 & -38.202 & -0.017 \\
\hline & U(HPO4) 2 & $\odot . \odot \odot \odot e+\odot \odot \odot$ & $\odot . \odot \odot \odot \mathrm{e}+\odot \odot \odot$ & -40.935 & -40.934 & $\odot .0 \odot \odot$ \\
\hline & $\mathrm{U}(\mathrm{OH}) 2+2$ & $\odot . \odot \odot \odot e+\odot \odot \odot$ & $\odot . \odot \odot \odot \mathrm{e}+\odot \odot \odot$ & -41.665 & -41.733 & -0.068 \\
\hline & UHPO4+2 & $\odot . \odot \odot \odot \mathrm{e}+\odot \odot \odot$ & $\odot . \odot \odot \odot \mathrm{e}+\odot \odot \odot$ & -45.405 & -45.473 & -0.068 \\
\hline & $\mathrm{UOH}+3$ & $\odot . \odot \odot \odot e+\odot \odot \odot$ & $\odot . \odot \odot \odot e+\odot \odot \odot$ & -46.099 & -46.251 & -0.152 \\
\hline & UF2+2 & $\odot . \odot \odot \odot e+\odot \odot \odot$ & $\odot . \odot \odot \odot e+\odot \odot \odot$ & -47.545 & -47.613 & -0.068 \\
\hline & $U F+3$ & $\odot .000 \mathrm{e}+00 \odot$ & $\odot .000 \mathrm{e}+00 \odot$ & -48.054 & -48.206 & -0.152 \\
\hline & UF3+ & $\odot . \odot \odot \odot e+\odot \odot \odot$ & $\odot . \odot \odot \odot \mathrm{e}+\odot \odot \odot$ & -48.057 & -48.074 & -0.017 \\
\hline & UF4 & $\odot . \odot \odot \odot e+\odot \odot \odot$ & $\odot . \odot \odot \odot e+\odot \odot \odot$ & -48.572 & -48.571 & $\odot .00 \odot$ \\
\hline & US04+2 & $\odot . \odot \odot \odot e+\odot \odot \odot$ & $\odot . \odot \odot \odot e+\odot \odot \odot$ & -50.390 & -50.458 & -0.068 \\
\hline & $\mathrm{U}(\mathrm{S} 04) 2$ & $\odot . \odot \odot \odot \mathrm{e}+\odot \odot \odot$ & $\odot . \odot \odot \odot \mathrm{e}+\odot \odot \odot$ & -50.549 & $-5 \odot .549$ & $\odot .0 \odot \odot$ \\
\hline & $\mathrm{U}+4$ & $\odot . \odot \odot \odot e+\odot \odot \odot$ & $\odot . \odot \odot \odot e+\odot \odot \odot$ & -51.278 & -51.548 & -0.270 \\
\hline & UF5- & $\odot . \odot \odot \odot e+\odot \odot \odot$ & $\odot . \odot \odot \odot e+\odot \odot \odot$ & -52.088 & -52.104 & -0.017 \\
\hline & UF6-2 & $\odot . \odot \odot \odot e+\odot \odot \odot$ & $\odot . \odot \odot \odot e+\odot \odot \odot$ & -54.618 & -54.685 & $-\odot .068$ \\
\hline & $\mathrm{U} 6(\mathrm{OH}) 15+9$ & $\odot . \odot \odot \odot e+\odot \odot \odot$ & $\odot . \odot \odot \odot e+\odot \odot \odot$ & -229.346 & -230.715 & -1.369 \\
\hline$U(5)$ & 6.20 & $-\odot 25$ & & & & \\
\hline$U(6)$ & U02+ & $\begin{array}{l}6.202 \mathrm{e}-025 \\
-011\end{array}$ & $5.965 e-025$ & 207 & 224 & -0.017 \\
\hline & U02(HP04)2-2 & $4.201 e-011$ & $3.596 e-011$ & -10.377 & -10.444 & -0.068 \\
\hline & U02HP04 & $1.251 \mathrm{e}-015$ & $1.252 \mathrm{e}-015$ & -14.903 & -14.903 & $\odot . \odot \odot \odot$ \\
\hline & $\mathrm{U} 02 \mathrm{CO} 3$ & $9.025 e-016$ & $9.028 e-016$ & -15.045 & -15.044 & $\odot .00 \odot$ \\
\hline & $\mathrm{U} 02(\mathrm{CO} 3) 2-2$ & $2.458 \mathrm{e}-016$ & $2.103 e-016$ & -15.609 & -15.677 & -0.068 \\
\hline & $\mathrm{U} 02 \mathrm{OH}+$ & $1.569 \mathrm{e}-017$ & $1.509 \mathrm{e}-017$ & -16.804 & -16.821 & -0.017 \\
\hline & U02H3Si04+ & $4.146 e-018$ & 3. $988 \mathrm{e}-018$ & -17.382 & -17.399 & -0.017 \\
\hline & U02+2 & $2.220 \mathrm{e}-018$ & $1.900 \mathrm{e}-018$ & -17.654 & -17.721 & $-\odot .068$ \\
\hline & U02F+ & $1.981 e-018$ & $1.905 e-018$ & -17.703 & -17.720 & -0.017 \\
\hline & $\mathrm{U} 02(\mathrm{CO} 3) 3-4$ & $1.130 \mathrm{e}-018$ & $6.062 \mathrm{e}-019$ & -17.947 & -18.217 & -0.270 \\
\hline & U02F2 & $9.796 \mathrm{e}-020$ & $9.799 \mathrm{e}-020$ & -19.009 & -19.009 & $\odot .00 \odot$ \\
\hline & $\mathrm{U} 02 \mathrm{H} 2 \mathrm{P} 04+$ & $4.156 e-020$ & $3.998 \mathrm{e}-020$ & -19.381 & -19.398 & -0.017 \\
\hline & U02S04 & $3.648 e-020$ & $3.649 \mathrm{e}-02 \odot$ & -19.438 & -19.438 & $\odot .0 \odot \odot$ \\
\hline & U02(H2P04) 2 & $4.922 \mathrm{e}-022$ & $4.923 e-022$ & -21.308 & -21.308 & $\odot .000$ \\
\hline & U02F3- & $2.133 e-022$ & $2.051 e-022$ & -21.671 & -21.688 & -0.017 \\
\hline & U02(S04)2-2 & $6.878 e-023$ & $5.886 e-023$ & -22.163 & -22.230 & -0.068 \\
\hline & U02(H2P04)3- & $1.822 \mathrm{e}-024$ & $1.752 \mathrm{e}-024$ & -23.740 & -23.756 & -0.017 \\
\hline & U02F4-2 & $3.244 \mathrm{e}-026$ & $2.776 \mathrm{e}-026$ & -25.489 & -25.557 & $-\odot .068$ \\
\hline & $(\mathrm{UO} 2) 2(\mathrm{OH}) 2+2$ & $2.271 e-029$ & $1.944 \mathrm{e}-029$ & -28.644 & -28.711 & -0.068 \\
\hline & (U02)3(OH)5+ & $1.660 \mathrm{e}-038$ & $1.597 \mathrm{e}-038$ & -37.780 & -37.797 & -0.017 \\
\hline
\end{tabular}


Saturation indices $\ldots \ldots \ldots \ldots$

Phase

(U02)3(P04)2

Akerminite

Anhydrite

Anilite

Antlerite

Aragonite

Artinite

Autunite

Azurite

B UO2 $(\mathrm{OH}) 2$

BlaubleiI

BlaubleiII

Brochantite

Brucite

Ca-Olivine

Ca3sio5

Calcite

$\mathrm{CH} 4$ (g)

Chalcanthite

Chalcedony

chalcocite

Chrysotile

Clinoenstatite

C02(g)

Covellite

Cristobalite

$\mathrm{Cu}(\mathrm{OH}) 2$

$\mathrm{Cu} 2 \mathrm{SO} 4$

Cu3(P04) 2

Cu3(P04) 2 : 3H2O

$\mathrm{CuCO} 3$

CuF

CuF2
SI $\log$ IAP $\log \mathrm{KT}$

\begin{tabular}{|c|c|c|c|}
\hline-23.82 & -76.54 & -52.72 & $(\mathrm{U} 02) 3(\mathrm{P0} 04) 2$ \\
\hline-30.96 & 19.49 & 50.44 & Ca2MgSi207 \\
\hline-3.24 & -7.73 & -4.49 & CaSO4 \\
\hline-81.79 & -155.34 & -73.55 & Cu0.25Cu1.5S \\
\hline-5.08 & 3.21 & 8.29 & $\mathrm{Cu} 3(\mathrm{OH}) 4 \mathrm{SO} 4$ \\
\hline-2.65 & -10.91 & -8.26 & CaC03 \\
\hline-14.36 & -3.64 & 10.72 & $\operatorname{MgCO} 3: \operatorname{Mg}(\mathrm{OH}) 2: 3 \mathrm{H} 20$ \\
\hline-18.95 & -62.32 & -43.37 & $\mathrm{Ca}(\mathrm{U} 02) 2(\mathrm{P} 04) 2$ \\
\hline-4.15 & -20.15 & -16.00 & $\mathrm{Cu} 3(\mathrm{OH}) 2(\mathrm{CO} 3) 2$ \\
\hline-11.02 & -4.95 & 6.08 & $\mathrm{U02}(\mathrm{OH}) 2$ \\
\hline-78.49 & -139.17 & -60.69 & Cu0.9Cu0.2S \\
\hline-81.24 & -146.63 & -65.40 & Cu0.6Cu0.8S \\
\hline-5.39 & 9.95 & 15.34 & $\mathrm{Cu} 4(\mathrm{OH}) 6 \mathrm{SO} 4$ \\
\hline-9.53 & 8.27 & 17.80 & $\mathrm{Mg}(\mathrm{OH}) 2$ \\
\hline-24.89 & 14.88 & 39.77 & Ca2SiO4 \\
\hline-53.84 & 24.15 & 78.00 & Ca3Si05 \\
\hline-2.50 & -10.91 & -8.41 & CaC03 \\
\hline 104.14 & -146.60 & -42.47 & $\mathrm{CH} 4$ \\
\hline-7.57 & -10.26 & -2.70 & CuSO4: $5 \mathrm{H} 20$ \\
\hline 0.04 & -3.66 & -3.70 & SiO2 \\
\hline-83.71 & -161.56 & -77.84 & Cu2S \\
\hline-16.74 & 17.48 & 34.23 & $\operatorname{Mg} 3 S i 205(\mathrm{OH}) 4$ \\
\hline-7.51 & 4.61 & 12.12 & MgSi03 \\
\hline-2.00 & -20.18 & -18.18 & $\mathrm{CO} 2$ \\
\hline-76.72 & -136.69 & -59.97 & CuS \\
\hline 0.14 & -3.66 & -3.80 & SiO2 \\
\hline-2.49 & 6.74 & 9.23 & $\mathrm{Cu}(\mathrm{OH}) 2$ \\
\hline-28.05 & -35.13 & -7.08 & Cu2S04 \\
\hline-4.64 & -41.49 & -36.85 & Cu3(P04) 2 \\
\hline-6.37 & -41.49 & -35.12 & Cu3(P04) 2 : 3H2O \\
\hline-3.81 & $-13 \cdot 44$ & -9.63 & CuC03 \\
\hline-25.48 & -20.57 & 4.90 & CuF \\
\hline-16 & -16 & -0.10 & $\mathrm{Cu}$ \\
\hline
\end{tabular}




\begin{tabular}{|c|c|c|c|c|}
\hline CuF2 : $2 \mathrm{H} 2 \mathrm{O}$ & -11.87 & -16.28 & -4.41 & CuF2 : $2 \mathrm{H} 2 \mathrm{O}$ \\
\hline CuMetal & -12.79 & -24.87 & -12.08 & $\mathrm{Cu}$ \\
\hline CuOCuSO4 & $-16 \cdot 44$ & -3.53 & 12.91 & CuO : CuSO4 \\
\hline Cuprite & -11.03 & $-18 \cdot 13$ & -7.10 & Cu20 \\
\hline CuSO4 & -13.98 & -10.26 & 3.71 & CuSO4 \\
\hline Diopside & -10.93 & 10.21 & 21.14 & CaMgSi206 \\
\hline Dioptase & -3.77 & 3.07 & 6.85 & CuSi03:H2O \\
\hline Djurleite & -83.18 & -159.91 & -76.74 & Cu०. 066Cu1. 868S \\
\hline Dolomite & -6.14 & -22.82 & -16.68 & $\mathrm{CaMg}(\mathrm{CO} 3) 2$ \\
\hline Epsomite & -6.48 & -8.73 & -2.25 & MgSO4 : 7H2O \\
\hline FC03Apatite & 3.43 & -112.50 & -115.93 & Ca9 . 316Na0.36Mg0.144(P04) $4.8(\mathrm{CO}) 1.2 \mathrm{~F} 2.48$ \\
\hline Fluorite & -2.95 & -13.74 & -10.80 & CaF2 \\
\hline Forsterite & -17.31 & 12.88 & 30.18 & Mg2Si04 \\
\hline Gummite & -16.24 & -4.95 & 11.30 & U03 \\
\hline Gypsum & -2.87 & -7.73 & -4.86 & CaSO4: $2 \mathrm{H} 20$ \\
\hline H-Autunite & -23.80 & -71.60 & -47.79 & $\mathrm{H} 2(\mathrm{U} 02) 2(\mathrm{P} 04) 2$ \\
\hline Huntite & -17.67 & -46.64 & -28.97 & CaMg3( C03) 4 \\
\hline Hydromagnesite & -32.63 & -39.37 & -6.74 & $\operatorname{Mg} 5(\mathrm{CO} 3) 4(\mathrm{OH}) 2: 4 \mathrm{H} 20$ \\
\hline Hydroxyapatite & -1.99 & -46.19 & -44.20 & $\mathrm{Ca5}(\mathrm{P0} 04) 30 \mathrm{H}$ \\
\hline K-Autunite & -19.66 & -68.13 & -48.47 & K2(U02)2(P04)2 \\
\hline Langite & -8.38 & 9.95 & 18.33 & $\mathrm{Cu} 4(\mathrm{OH}) 6 \mathrm{SO} 4: \mathrm{H} 2 \mathrm{O}$ \\
\hline Larnite & -26.48 & 14.88 & 41.36 & Ca2SiO4 \\
\hline Lime & -25.32 & 9.27 & 34.59 & $\mathrm{CaO}$ \\
\hline Magadiite & -9.23 & -23.53 & -14.30 & NaSi7013(OH) 3: 3H20 \\
\hline Magnesite & -4.12 & -11.91 & -7.79 & $\mathrm{MgCO} 3$ \\
\hline Malachite & -2.13 & -6.71 & -4.57 & $\mathrm{Cu} 2(\mathrm{OH}) 2 \mathrm{CO} 3$ \\
\hline Merwinite & -43.94 & 28.76 & 72.70 & Ca3MgSi208 \\
\hline Mirabilite & -10.91 & -12.76 & -1.85 & $\mathrm{Na2S0} 4: 10 \mathrm{H} 20$ \\
\hline Monticellite & $-18 \cdot 31$ & 13.88 & 32.19 & CaMgSiO4 \\
\hline Na-Autunite & -19.96 & -67.35 & -47.39 & $\mathrm{Na2}(\mathrm{U} 02) 2(\mathrm{P0} 4) 2$ \\
\hline Natron & -14.01 & -15.94 & -1.92 & $\mathrm{Na} 2 \mathrm{CO} 3: 10 \mathrm{H} 20$ \\
\hline Nesquehonite & -6.51 & -11.91 & -5.40 & MgC03:3H2O \\
\hline Ningyoite & -24.61 & -88.98 & -64.37 & $\mathrm{CaU}(\mathrm{P0} 04) 2: 2 \mathrm{H} 20$ \\
\hline $02(\mathrm{~g})$ & -25.10 & 63.21 & 88.32 & 02 \\
\hline P-Wollstanite & -9.06 & 5.61 & 14.66 & CaSi03 \\
\hline Periclase & -14.64 & 8.27 & 22.91 & MgO \\
\hline Portlandite & -14.59 & 9.27 & 23.87 & $\mathrm{Ca}(\mathrm{OH}) 2$ \\
\hline Quartz & $\odot .58$ & -3.66 & -4.25 & SiO2 \\
\hline
\end{tabular}




\begin{tabular}{|c|c|c|c|c|}
\hline Rutherfordine & -10.68 & -25.13 & -14.45 & U02C03 \\
\hline Saleeite & -20.46 & -63.33 & -42.86 & $\mathrm{Mg}(\mathrm{U} 02) 2(\mathrm{P} 04) 2$ \\
\hline Schoepite & -10.82 & -4.95 & 5.87 & $\mathrm{UO} 2(\mathrm{OH}) 2: \mathrm{H} 2 \mathrm{O}$ \\
\hline Sepiolite(a) & -13.23 & 5.55 & 18.78 & Mg2Si307.5OH:3H20 \\
\hline Sepiolite(c) & $-11 \cdot 43$ & 5.55 & 16.97 & Mg2Si307.5OH:3H20 \\
\hline $\operatorname{Si02(a)}$ & -0.47 & -3.66 & -3.19 & Si02 \\
\hline Si02( $(\mathrm{am})$ & -0.80 & -3.66 & -2.86 & Si02 \\
\hline SULFUR & -73.88 & -111.82 & -37.94 & S \\
\hline Talc & -14.26 & 10.15 & 24.41 & $\operatorname{Mg} 3 S i 4010(\mathrm{OH}) 2$ \\
\hline Tenorite & -1.47 & 6.74 & 8.21 & CuO \\
\hline Thenardite & -12.60 & -12.76 & -0.16 & $\mathrm{Na2S0} 4$ \\
\hline Thermonatrite & -16.17 & -15.94 & 0.23 & $\mathrm{Na} 2 \mathrm{CO} 3: \mathrm{H} 2 \mathrm{O}$ \\
\hline Torbernite & -20.20 & -64.86 & -44.66 & $\mathrm{Cu}(\mathrm{U} 02) 2(\mathrm{P} 04) 2$ \\
\hline Tremolite & -29.72 & 30.58 & 60.30 & Ca2Mg5Si8022(OH) 2 \\
\hline $\mathrm{U}(\mathrm{HPO} 4) 2$ & -35.97 & -98.25 & -62.29 & U(HPO4) 2 \\
\hline U308(C) & -40.40 & -46.45 & -6.05 & U308 \\
\hline U409(C) & -72.94 & -114.61 & -41.66 & U409 \\
\hline UF4(C) & -54.16 & -82.59 & -28.43 & UF4 \\
\hline UF4 : $2.5 \mathrm{H} 20$ & -44.49 & -82.59 & -38.10 & UF4 : $2.5 \mathrm{H} 20$ \\
\hline U02 ( am ) & -27.95 & -36.55 & -8.60 & U02 \\
\hline U03(C) & -13.42 & -4.95 & 8.47 & U03 \\
\hline Uraninite & -22.02 & -36.55 & -14.53 & U02 \\
\hline hane & -25.44 & -7.95 & 17.49 & $\mathrm{Ca}(\mathrm{U} 02) 2(\mathrm{SiO} 30 \mathrm{H}) 2$ \\
\hline USi04(C) & -22.61 & -40.22 & -17.61 & USi04 \\
\hline tonite & -8.15 & 5.61 & 13.75 & CaSi03 \\
\hline
\end{tabular}


Table 7 CFC-Derived Apparent Recharge Years. The HILLTOP well, which has low U, has younger water than the PLAKE2, which has high U.

\begin{tabular}{|c|c|c|c|}
\hline Sample ID & CFC-11 & CFC-12 & CFC-113 \\
\hline HILLTOP 1 & 1991 & $\mathrm{C} / \mathrm{M}^{\mathrm{a}}$ & 1990 \\
\hline HILLTOP 2 & $\mathrm{C} / \mathrm{M}^{\mathrm{a}}$ & $\mathrm{C} / \mathrm{M}^{\mathrm{a}}$ & 2001 \\
\hline HILLTOP 3 & $\mathrm{C} / \mathrm{M}^{\mathrm{a}}$ & $\mathrm{C} / \mathrm{M}^{\mathrm{a}}$ & 1993 \\
\hline HILLTOP 4 & $\mathrm{C} / \mathrm{M}^{\mathrm{a}}$ & $\mathrm{C} / \mathrm{M}^{\mathrm{a}}$ & 2001 \\
\hline PLAKE2 1 & 1956 & 1957 & 1943 \\
\hline PLAKE2 2 & 1956 & 1954 & 1943 \\
\hline PLAKE2 3 & 1955 & 1954 & 1943 \\
\hline PLAKE2 4 & 1955 & 1959 & 1943 \\
\hline HILLBTM 1 & 1962 & $\mathrm{C} / \mathrm{M}^{\mathrm{a}}$ & 1943 \\
\hline HILLBTM 2 & 1962 & $\mathrm{C} / \mathrm{M}^{\mathrm{a}}$ & 1943 \\
\hline HILLBTM 3 & 1962 & $\mathrm{C} / \mathrm{M}^{\mathrm{a}}$ & 1943 \\
\hline HILLBTM 4 & 1962 & $\mathrm{C} / \mathrm{M}^{\mathrm{a}}$ & 1943 \\
\hline
\end{tabular}

${ }^{a}$ Contaminated or Modern Sample. 
Table 8 Summary of Spectral Gamma-Ray Data for Wells.

\begin{tabular}{|c|c|c|c|c|c|c|c|c|c|c|c|c|c|c|}
\hline \multirow[b]{2}{*}{ Well } & \multicolumn{2}{|l|}{ Water U } & \multicolumn{3}{|l|}{$\mathrm{K}(\%)$} & \multicolumn{3}{|c|}{$\mathrm{eU}(\mathrm{ppm})$} & \multicolumn{3}{|c|}{ eTh (ppm) } & \multicolumn{3}{|l|}{$\mathrm{eTh} / \mathrm{K}$} \\
\hline & (ppb) & $\mathrm{n}$ & Mean & STDEV & Range & Mean & STDEV & Range & Mean & STDEV & Range & Mean & STDEV & Range \\
\hline KBAYCOM & 25.10 & 132 & 2.3 & $\begin{array}{c}0.6 \\
24 \%\end{array}$ & $\begin{array}{l}0.8 \\
3.3\end{array}$ & 3.5 & $\begin{array}{c}0.9 \\
26 \%\end{array}$ & $\begin{array}{l}1.5 \\
6.6\end{array}$ & 5.1 & $\begin{array}{c}1.7 \\
33 \%\end{array}$ & $\begin{array}{c}2.2 \\
12.3\end{array}$ & 2.2 & $\begin{array}{c}0.7 \\
33 \%\end{array}$ & $\begin{array}{l}0.9 \\
5.5\end{array}$ \\
\hline AIRPRTRD & no data & 129 & 2.1 & $\begin{array}{c}0.6 \\
27 \% \\
\end{array}$ & $\begin{array}{l}1.0 \\
3.7\end{array}$ & 2.2 & $\begin{array}{c}0.6 \\
26 \% \\
\end{array}$ & $\begin{array}{l}1.2 \\
4.5\end{array}$ & 3.4 & $\begin{array}{c}1.3 \\
36 \% \\
\end{array}$ & $\begin{array}{c}1.8 \\
11.2\end{array}$ & 1.7 & $\begin{array}{c}0.6 \\
33 \% \\
\end{array}$ & $\begin{array}{l}0.9 \\
5.1\end{array}$ \\
\hline CHASLAKE & $3(\mathrm{pCi} / \mathrm{I}$ & 104 & 1.9 & $\begin{array}{c}0.8 \\
45 \%\end{array}$ & $\begin{array}{l}0.8 \\
3.3\end{array}$ & 2.1 & $\begin{array}{c}1.2 \\
56 \%\end{array}$ & $\begin{array}{c}1 \\
4.8\end{array}$ & 4.5 & $\begin{array}{c}3.2 \\
71 \%\end{array}$ & $\begin{array}{c}1.7 \\
13.2\end{array}$ & 2.2 & $\begin{array}{c}0.6 \\
29 \%\end{array}$ & $\begin{array}{l}1.4 \\
4.6\end{array}$ \\
\hline CHASHILL2 & 7.90 & 345 & 2.4 & $\begin{array}{c}0.9 \\
39 \%\end{array}$ & $\begin{array}{l}0.7 \\
5.4\end{array}$ & 3.6 & $\begin{array}{c}1.8 \\
48 \%\end{array}$ & $\begin{array}{c}1.2 \\
11.5\end{array}$ & 4.6 & $\begin{array}{c}2.4 \\
52 \%\end{array}$ & $\begin{array}{c}1.5 \\
11.4\end{array}$ & 1.9 & $\begin{array}{c}0.5 \\
26 \%\end{array}$ & $\begin{array}{l}0.9 \\
3.5\end{array}$ \\
\hline CHASHILL3 & $<10$ & 279 & 2.2 & $\begin{array}{c}0.8 \\
38 \%\end{array}$ & $\begin{array}{l}0.9 \\
4.1\end{array}$ & 2.9 & $\begin{array}{c}1.5 \\
52 \%\end{array}$ & $\begin{array}{c}0.9 \\
10.6\end{array}$ & 4.2 & $\begin{array}{c}2.1 \\
50 \%\end{array}$ & $\begin{array}{l}1.5 \\
9.7\end{array}$ & 1.9 & $\begin{array}{c}0.4 \\
24 \%\end{array}$ & $\begin{array}{l}0.8 \\
4.3\end{array}$ \\
\hline CHASHILL4 & 18.6 & 81 & 2.2 & $\begin{array}{c}1 \\
44 \%\end{array}$ & $\begin{array}{l}0.8 \\
4.8\end{array}$ & 3 & $\begin{array}{c}2.8 \\
65 \%\end{array}$ & $\begin{array}{c}1.4 \\
14.8\end{array}$ & 4.7 & $\begin{array}{c}2.4 \\
51 \%\end{array}$ & $\begin{array}{l}1.5 \\
11\end{array}$ & 2.2 & $\begin{array}{c}0.7 \\
32 \%\end{array}$ & $\begin{array}{l}0.9 \\
4.3\end{array}$ \\
\hline PLAKE1 & 54.1 & 127 & 2.3 & $\begin{array}{c}0.9 \\
38 \% \\
\end{array}$ & $\begin{array}{c}0.4 \\
4\end{array}$ & 2.4 & $\begin{array}{c}1 \\
39 \% \\
\end{array}$ & $\begin{array}{l}1.3 \\
6.4\end{array}$ & 3.8 & $\begin{array}{c}1.9 \\
51 \%\end{array}$ & $\begin{array}{c}1.4 \\
13.5\end{array}$ & 1.8 & $\begin{array}{c}0.8 \\
43 \%\end{array}$ & $\begin{array}{l}0.8 \\
4.1 \\
\end{array}$ \\
\hline HILLBTM & 1.19 & 136 & 1.3 & $\begin{array}{c}0.7 \\
51 \%\end{array}$ & $\begin{array}{l}0.2 \\
3.1\end{array}$ & 1.8 & $\begin{array}{c}0.4 \\
24 \%\end{array}$ & $\begin{array}{l}1.1 \\
3.6\end{array}$ & 3 & $\begin{array}{c}1.1 \\
37 \%\end{array}$ & $\begin{array}{c}1.4 \\
6\end{array}$ & 2.8 & $\frac{1.5}{52 \%}$ & $\begin{array}{l}1.2 \\
10\end{array}$ \\
\hline PLAKE3 & 84.8 & 113 & 1.8 & $\begin{array}{c}0.7 \\
37 \%\end{array}$ & $\begin{array}{l}0.7 \\
3.5\end{array}$ & 2.3 & $\begin{array}{c}1.3 \\
56 \%\end{array}$ & $\begin{array}{c}1 \\
8.6\end{array}$ & 3.5 & $\begin{array}{c}1.8 \\
52 \%\end{array}$ & $\begin{array}{c}1.7 \\
10.3\end{array}$ & 2 & $\begin{array}{c}0.4 \\
22 \%\end{array}$ & $\begin{array}{c}1.1 \\
4\end{array}$ \\
\hline PEQUAMING & 11 & 166 & 2 & $\begin{array}{c}0.4 \\
20 \%\end{array}$ & $\begin{array}{c}1 \\
2.9\end{array}$ & 3.5 & $\begin{array}{c}0.8 \\
24 \%\end{array}$ & $\begin{array}{l}1.3 \\
5.8\end{array}$ & 7.8 & $\begin{array}{c}2.1 \\
27 \%\end{array}$ & $\begin{array}{c}2.5 \\
12.7\end{array}$ & 3.8 & $\begin{array}{c}0.8 \\
21 \%\end{array}$ & $\begin{array}{c}2 \\
7.1\end{array}$ \\
\hline HILLTOP & & 113 & 2.5 & $\begin{array}{c}0.4 \\
16 \%\end{array}$ & $\begin{array}{l}1.1 \\
3.3\end{array}$ & 2.4 & $\begin{array}{c}1 \\
39 \%\end{array}$ & $\begin{array}{c}1 \\
7.9\end{array}$ & 4.6 & $\begin{array}{c}3.8 \\
84 \%\end{array}$ & $\begin{array}{c}2.1 \\
28.8\end{array}$ & 1.8 & $\begin{array}{c}1.4 \\
75 \%\end{array}$ & $\begin{array}{c}0.8 \\
10.7\end{array}$ \\
\hline PLAKE2 & 97 & 146 & 2.1 & $\begin{array}{c}0.7 \\
33 \%\end{array}$ & $\begin{array}{l}0.3 \\
3.6 \\
\end{array}$ & 3.5 & $\begin{array}{c}2.8 \\
80 \%\end{array}$ & $\begin{array}{c}1 \\
22.2\end{array}$ & 4.1 & $\begin{array}{c}1.8 \\
45 \%\end{array}$ & $\begin{array}{l}1.6 \\
10\end{array}$ & 2 & $\begin{array}{c}0.8 \\
40 \%\end{array}$ & $\begin{array}{l}0.7 \\
6.7\end{array}$ \\
\hline
\end{tabular}

Continued 


\begin{tabular}{|c|c|c|c|c|c|c|c|c|c|}
\hline \multirow[b]{2}{*}{ Well } & \multirow[b]{2}{*}{ Clay Type } & \multicolumn{3}{|l|}{$\mathrm{eTh} / \mathrm{eU}$} & \multirow{2}{*}{$\mathrm{eU} / \mathrm{K}>\mathrm{Th} / \mathrm{eU}$} & \multicolumn{4}{|c|}{ Correlations } \\
\hline & & Mean & STDEV & Range & & $\mathrm{eU}$ eTh & $\mathrm{eU} \mathrm{K}$ & eTh K & $\mathrm{eU} \mathrm{eTh} / \mathrm{K}$ \\
\hline KBAYCOM & Illite, Mica, Glauconite, Mixed Layer & 1.5 & 0.5 & 0.6 & 63 & 0.38 & 0.23 & 0.40 & 0.17 \\
\hline & & & $35 \%$ & 3.4 & $48 \%$ & & & & \\
\hline AIRPRTRD & Mica, Glauconite, Illite, Mixed layer & 1.6 & $\begin{array}{c}0.5 \\
30 \%\end{array}$ & $\begin{array}{l}0.8 \\
3.4\end{array}$ & $\begin{array}{c}34 \\
26 \%\end{array}$ & 0.45 & 0.49 & 0.42 & 0.13 \\
\hline CHASLAKE & Illite, Mica, Mixed layer & 2.1 & $\begin{array}{c}0.5 \\
22 \% \\
\end{array}$ & $\begin{array}{l}1.1 \\
3.6 \\
\end{array}$ & $\begin{array}{c}5 \\
5 \% \\
\end{array}$ & 0.95 & 0.93 & 0.95 & 0.8 \\
\hline CHASHILL2 & Illite, Mica, Glauconite & 1.3 & $\begin{array}{c}0.4 \\
34 \%\end{array}$ & $\begin{array}{l}0.4 \\
2.5\end{array}$ & $\begin{array}{l}175 \\
51 \%\end{array}$ & 0.65 & 0.52 & 0.87 & 0.48 \\
\hline CHASHILL3 & Illite, Mica, Glauconite & 1.6 & $\begin{array}{c}0.5 \\
35 \%\end{array}$ & $\begin{array}{l}0.3 \\
3.4\end{array}$ & $\begin{array}{c}99 \\
35 \%\end{array}$ & 0.61 & 0.56 & 0.89 & 0.32 \\
\hline CHASHILL4 & Illite, Mica, Glauconite, Mixed layer & 1.3 & $\begin{array}{l}0.6 \\
45 \%\end{array}$ & $\begin{array}{l}0.2 \\
2.8\end{array}$ & $\begin{array}{c}53 \\
65 \%\end{array}$ & 0.36 & 0.36 & 0.88 & 0.01 \\
\hline PLAKE1 & Glauconite, Mica, Illite, Mixed layer & 1.5 & $\begin{array}{c}0.3 \\
20 \%\end{array}$ & $\begin{array}{l}1.1 \\
2.8\end{array}$ & $\begin{array}{c}30 \\
24 \%\end{array}$ & 0.9 & 0.48 & 0.48 & 0.38 \\
\hline HILLBTM & Illite, Glauconite, Mica, Mixed layer & 1.7 & $\begin{array}{c}0.5 \\
31 \%\end{array}$ & $\begin{array}{l}0.9 \\
4.6\end{array}$ & $\begin{array}{c}65 \\
48 \%\end{array}$ & 0.59 & 0.6 & 0.61 & -0.32 \\
\hline PLAKE3 & Illite, Mica, Mixed layer & 1.6 & $\begin{array}{c}0.4 \\
24 \%\end{array}$ & $\begin{array}{l}0.5 \\
2.9\end{array}$ & $\begin{array}{c}24 \\
21 \%\end{array}$ & 0.75 & 0.76 & 0.91 & 0.34 \\
\hline PEQUAMING & Mixed layer, Illite & 2.3 & $\begin{array}{c}0.5 \\
23 \%\end{array}$ & $\begin{array}{c}1 \\
3.8\end{array}$ & $\begin{array}{c}43 \\
26 \%\end{array}$ & 0.57 & 0.46 & 0.66 & 0.36 \\
\hline HILLTOP & Mica, Glauconite, Illite, Mixed layer & 1.8 & $\begin{array}{c}0.5 \\
26 \%\end{array}$ & $\begin{array}{l}1.1 \\
3.6\end{array}$ & $\begin{array}{c}4 \\
4 \%\end{array}$ & 0.94 & 0.29 & 0.2 & 0.9 \\
\hline PLAKE2 & Illite, Mica, Glauconite, Mixed layer & 1.3 & $\begin{array}{c}0.4 \\
30 \%\end{array}$ & $\begin{array}{l}0.2 \\
2.4\end{array}$ & $\begin{array}{c}66 \\
45 \%\end{array}$ & 0.56 & 0.15 & 0.59 & 0.47 \\
\hline
\end{tabular}


Table 9 Summary of Spectral Gamma-Ray Data for Outcrops.

\begin{tabular}{|c|c|c|c|c|c|c|c|c|c|c|c|c|c|c|}
\hline \multirow[t]{2}{*}{ Outcrop } & \multirow[b]{2}{*}{$\mathrm{n}$} & \multicolumn{3}{|l|}{$\mathrm{K}(\%)$} & \multicolumn{3}{|c|}{$\mathrm{eU}(\mathrm{ppm})$} & \multicolumn{3}{|c|}{ eTh (ppm) } & \multicolumn{4}{|l|}{$\mathrm{eTh} / \mathrm{K}$} \\
\hline & & Mean & STDEV & Range & Mean & STDEV & Range & Mean & STDEV & Range & Mean & STDEV & Range & Clay Type \\
\hline $\begin{array}{l}\text { Grand Island } \\
\text { Channel Abandonment }\end{array}$ & 24 & 6.6 & $\begin{array}{l}0.5 \\
8 \%\end{array}$ & $\begin{array}{l}5.6 \\
7.3 \\
\end{array}$ & 3.9 & $\begin{array}{c}1.6 \\
40 \% \\
\end{array}$ & $\begin{array}{l}1.9 \\
7.1 \\
\end{array}$ & 6.1 & $\begin{array}{c}0.9 \\
15 \% \\
\end{array}$ & $\begin{array}{c}4 \\
8.1 \\
8\end{array}$ & 0.9 & $\begin{array}{c}0.1 \\
16 \%\end{array}$ & $\begin{array}{l}0.7 \\
1.2\end{array}$ & glauconite \\
\hline $\begin{array}{l}\text { L'Anse } \\
\text { Main Channel }\end{array}$ & 37 & 4.5 & $\begin{array}{l}0.4 \\
8 \%\end{array}$ & $\begin{array}{l}3.6 \\
5.5\end{array}$ & 2.9 & $\begin{array}{l}0.6 \\
21 \%\end{array}$ & $\begin{array}{l}1.8 \\
4.4\end{array}$ & 6 & $\begin{array}{c}1.3 \\
21 \%\end{array}$ & $\begin{array}{c}4 \\
9.5\end{array}$ & 1.3 & $\begin{array}{c}0.3 \\
21 \%\end{array}$ & $\begin{array}{l}0.9 \\
2.2\end{array}$ & \begin{tabular}{|l} 
glauconite, mica, \\
illite
\end{tabular} \\
\hline $\begin{array}{l}\text { L'Anse } \\
\text { Unconformity }\end{array}$ & 6 & 4.5 & $\begin{array}{c}0.5 \\
10 \%\end{array}$ & $\begin{array}{c}3.8 \\
5\end{array}$ & 4.8 & $\begin{array}{c}1 \\
21 \%\end{array}$ & $\begin{array}{l}3.8 \\
6.5\end{array}$ & $\overline{9.1}$ & $\begin{array}{c}1.6 \\
18 \%\end{array}$ & $\begin{array}{c}7.6 \\
11.9\end{array}$ & 2.1 & $\begin{array}{c}0.6 \\
27 \%\end{array}$ & $\begin{array}{l}1.5 \\
3.1\end{array}$ & illite, mica \\
\hline $\begin{array}{l}\text { Keweenaw Bay } \\
\text { Deltaic Channel }\end{array}$ & 42 & 5.9 & $\begin{array}{c}0.6 \\
10 \% \\
\end{array}$ & $\begin{array}{l}3.8 \\
6.9\end{array}$ & 4.4 & $\begin{array}{l}2.1 \\
47 \%\end{array}$ & $\begin{array}{ll}1.8 \\
12.5 \\
\end{array}$ & 5.3 & $\begin{array}{r}1.3 \\
24 \% \\
\end{array}$ & $\begin{array}{l}2.8 \\
8.7 \\
\end{array}$ & 0.9 & $\begin{array}{c}0.2 \\
20 \% \\
\end{array}$ & $\begin{array}{l}0.5 \\
1.4 \\
\end{array}$ & glauconite, feldspar \\
\hline $\begin{array}{l}\text { Roadside Park } \\
\text { Lacustrine }\end{array}$ & 22 & 4.8 & $\begin{array}{c}0.5 \\
11 \% \\
\end{array}$ & $\begin{array}{c}3.8 \\
6 \\
\end{array}$ & 3.1 & $\begin{array}{c}1.3 \\
43 \% \\
\end{array}$ & $\begin{array}{l}1.5 \\
6.1 \\
\end{array}$ & 5.5 & $\begin{array}{l}2.6 \\
48 \% \\
\end{array}$ & $\begin{array}{c}2.4 \\
11.3 \\
\end{array}$ & 1.2 & $\begin{array}{l}0.6 \\
48 \% \\
\end{array}$ & $\begin{array}{l}0.5 \\
2.4 \\
\end{array}$ & $\begin{array}{l}\text { glauconite, illite, } \\
\text { feldspar }\end{array}$ \\
\hline $\begin{array}{l}\text { Pequaming } \\
\text { Alternating }\end{array}$ & 15 & 3.1 & $\begin{array}{l}0.9 \\
30 \%\end{array}$ & $\begin{array}{l}1.8 \\
4.5 \\
\end{array}$ & 4.4 & $\begin{array}{c}1.3 \\
29 \% \\
\end{array}$ & $\begin{array}{l}2.2 \\
6.2\end{array}$ & 10.1 & $\begin{array}{c}3 \\
29 \% \\
\end{array}$ & $\begin{array}{l}4.5 \\
14.2\end{array}$ & 3.3 & $\begin{array}{c}0.7 \\
21 \% \\
\end{array}$ & $\begin{array}{l}2.5 \\
4.9 \\
\end{array}$ & illite, mixed layer \\
\hline $\begin{array}{l}\text { Keweenaw Bay } \\
\text { Lacustrine }\end{array}$ & 14 & 5.6 & $\begin{array}{l}0.4 \\
7 \% \\
\end{array}$ & $\begin{array}{l}4.9 \\
6.4 \\
\end{array}$ & 2.4 & $\begin{array}{c}0.5 \\
21 \% \\
\end{array}$ & $\begin{array}{l}1.8 \\
3.3 \\
\end{array}$ & 4.5 & $\begin{array}{c}0.7 \\
16 \% \\
\end{array}$ & $\begin{array}{l}3.4 \\
5.9 \\
\end{array}$ & 0.8 & $\begin{array}{c}0.1 \\
14 \% \\
\end{array}$ & $\begin{array}{l}0.5 \\
0.9\end{array}$ & glauconite \\
\hline $\begin{array}{l}\text { Jacobsville } \\
\text { Lacustrine }\end{array}$ & 39 & 4.4 & $\begin{array}{l}0.4 \\
9 \% \\
\end{array}$ & $\begin{array}{l}3.6 \\
5.1 \\
\end{array}$ & 3.1 & $\begin{array}{c}1.4 \\
46 \% \\
\end{array}$ & $\begin{array}{l}1.4 \\
6.8 \\
\end{array}$ & 4.6 & $\begin{array}{c}1.6 \\
35 \% \\
\end{array}$ & $\begin{array}{l}1.9 \\
8.2 \\
\end{array}$ & 1 & $\begin{array}{c}0.3 \\
30 \% \\
\end{array}$ & $\begin{array}{l}0.5 \\
1.9 \\
\end{array}$ & $\begin{array}{l}\text { glauconite, feldspar } \\
\text { mica }\end{array}$ \\
\hline $\begin{array}{l}\text { Traverse } \\
\text { Alternating }\end{array}$ & 21 & 4.2 & $\begin{array}{c}0.6 \\
14 \% \\
\end{array}$ & $\begin{array}{c}2.6 \\
5\end{array}$ & 3.7 & $\begin{array}{c}1 \\
29 \% \\
\end{array}$ & $\begin{array}{l}2 \\
6 \\
\end{array}$ & 8.9 & $\begin{array}{c}3.3 \\
37 \%\end{array}$ & $\begin{array}{l}1.7 \\
15.8 \\
\end{array}$ & 2.1 & $\begin{array}{c}0.6 \\
27 \% \\
\end{array}$ & $\begin{array}{l}0.7 \\
3.2\end{array}$ & $\begin{array}{l}\text { illite, mica, } \\
\text { glauconite }\end{array}$ \\
\hline $\begin{array}{l}\text { Gay } \\
\text { Alternating }\end{array}$ & 11 & 4.4 & $\begin{array}{c}0.5 \\
10 \% \\
\end{array}$ & $\begin{array}{l}3.4 \\
5.1 \\
\end{array}$ & 3.5 & $\begin{array}{c}1 \\
28 \%\end{array}$ & $\begin{array}{l}1.8 \\
5.2\end{array}$ & 5.7 & $\begin{array}{r}1.7 \\
30 \% \\
\end{array}$ & $\begin{array}{c}4 \\
9.4 \\
\end{array}$ & 1.3 & $\begin{array}{c}0.3 \\
23 \% \\
\end{array}$ & $\begin{array}{c}1 \\
1.8\end{array}$ & glauconite, mica \\
\hline
\end{tabular}

Continued 


\begin{tabular}{|c|c|c|c|c|c|c|c|c|c|}
\hline \multirow[t]{2}{*}{ Outcrop } & \multicolumn{3}{|l|}{$\mathrm{eTh} / \mathrm{eU}$} & \multirow[t]{2}{*}{$\mathrm{eU} / \mathrm{K}>\mathrm{eTh}$} & \multicolumn{4}{|c|}{ Correlations } & \multirow{2}{*}{$\begin{array}{l}\text { Type of U } \\
\text { Enrichment }\end{array}$} \\
\hline & Mean & STDEV & Range & & eU eTh & eU K & eTh K & $\mathrm{eU} \mathrm{eTh} / \mathrm{K}$ & \\
\hline Grand Island & 1.8 & 0.8 & 0.8 & 1 & -0.12 & -0.07 & 0.28 & -0.08 & fluid flow \\
\hline Channel Abandonment & & $47 \%$ & 3.8 & $4 \%$ & & & & & clay \\
\hline $\begin{array}{l}\text { L'Anse } \\
\text { Main Channel }\end{array}$ & 2.1 & $\begin{array}{c}0.6 \\
30 \%\end{array}$ & $\begin{array}{l}1.2 \\
4.2\end{array}$ & none & 0.24 & -0.06 & 0.22 & 0.26 & not enriched \\
\hline $\begin{array}{l}\text { L'Anse } \\
\text { Unconformity }\end{array}$ & 1.9 & $\begin{array}{c}0.5 \\
23 \%\end{array}$ & $\begin{array}{l}1.5 \\
2.8\end{array}$ & none & 0.27 & 0.23 & -0.61 & 0.04 & \\
\hline $\begin{array}{l}\text { Keweenaw Bay } \\
\text { Deltaic Channel }\end{array}$ & $\overline{1.4}$ & $\begin{array}{c}0.6 \\
41 \%\end{array}$ & $\begin{array}{l}0.5 \\
2.8\end{array}$ & $\begin{array}{c}12 \\
29 \% \\
\end{array}$ & $\overline{0.4}$ & 0.17 & 0.61 & 0.38 & fluid flow \\
\hline $\begin{array}{l}\text { Roadside Park } \\
\text { Lacustrine }\end{array}$ & 1.8 & $\begin{array}{c}0.4 \\
25 \%\end{array}$ & $\begin{array}{c}1 \\
2.7\end{array}$ & none & 0.89 & 0.01 & 0.05 & 0.87 & $\begin{array}{l}\text { heavy } \\
\text { mineral }\end{array}$ \\
\hline $\begin{array}{l}\text { Pequaming } \\
\text { Alternating }\end{array}$ & 2.4 & $\begin{array}{c}0.6 \\
27 \%\end{array}$ & $\begin{array}{l}1.3 \\
3.9\end{array}$ & $\begin{array}{c}2 \\
13 \% \\
\end{array}$ & 0.62 & 0.79 & 0.79 & -0.24 & $\begin{array}{l}\text { high Th \& } \\
\text { cross over }\end{array}$ \\
\hline $\begin{array}{l}\text { Keweenaw Bay } \\
\text { Lacustrine }\end{array}$ & 1.9 & $\begin{array}{c}0.3 \\
16 \% \\
\end{array}$ & $\begin{array}{l}1.5 \\
2.7\end{array}$ & none & 0.72 & 0.23 & 0.37 & 0.66 & not enriched \\
\hline $\begin{array}{l}\text { Jacobsville } \\
\text { Lacustrine }\end{array}$ & 1.7 & $\begin{array}{c}0.7 \\
41 \%\end{array}$ & $\begin{array}{l}0.6 \\
3.5\end{array}$ & $\begin{array}{c}5 \\
13 \%\end{array}$ & 0.21 & 0.06 & 0.71 & 0.25 & fluid flow \\
\hline $\begin{array}{l}\text { Traverse } \\
\text { Alternating }\end{array}$ & 2.4 & $\begin{array}{c}0.7 \\
30 \%\end{array}$ & $\begin{array}{l}0.9 \\
4.8\end{array}$ & none & 0.77 & 0.7 & 0.93 & 0.76 & $\begin{array}{l}\text { heavy } \\
\text { mineral }\end{array}$ \\
\hline $\begin{array}{l}\text { Gay } \\
\text { Alternating }\end{array}$ & 1.7 & $\begin{array}{c}0.4 \\
24 \%\end{array}$ & $\begin{array}{l}1.3 \\
2.6\end{array}$ & none & 0.76 & 0.92 & 0.73 & 0.55 & $\begin{array}{l}\text { heavy } \\
\text { mineral }\end{array}$ \\
\hline
\end{tabular}


Table 10 Total and Partial U and Illite\%. Clay type does not appear to influence total or leached U. XRD analysis by McDowell (2004).

\begin{tabular}{|c|c|c|c|c|c|}
\hline & & \begin{tabular}{|l} 
U, FI. Total \\
Digestion
\end{tabular} & $\begin{array}{l}\text { U, FI. Partial } \\
\text { Digestion }\end{array}$ & $\begin{array}{l}\text { Partial/ Total } \\
\text { U \% }\end{array}$ & $\begin{array}{l}\text { Illite/(illite + } \\
\text { smectite) \% }\end{array}$ \\
\hline & & ppm & ppm & & \\
\hline Depth (feet) & description (log U ppm) & & & & \\
\hline 767.6 & rd sandstone & 5.8 & 3.1 & 53 & 72 \\
\hline 1068.7 & gray & 6.5 & 2.62 & 40 & 77 \\
\hline 1069.8 & gray & 3.5 & 0.9 & 26 & 82 \\
\hline 1147 & dk gry clayey $(10)$ & 3.7 & 1.22 & 33 & 88.5 \\
\hline 1415.1 & rd xbedded, silty sandstone & 2.5 & 0.57 & 23 & 63 \\
\hline 1513.1 & id & 2.8 & 1.24 & 44 & 82 \\
\hline 1539.6 & rd w/mud chips & 2.2 & 1.19 & 54 & 82 \\
\hline 1628.1 & rd 1" rip up clast $(>10)$ & 4.6 & 2.14 & 47 & 89.7 \\
\hline 1771.6 & $\mathrm{rd} / \mathrm{gry}$ & 4.4 & 1.48 & 34 & 94 \\
\hline 1828.25 & rd silty $3^{\prime \prime}(2.5$, below 6$)$ & 3.6 & 1.71 & 48 & 85.3 \\
\hline 1938.8 & red - rusty, mudstone & 4.8 & 1.33 & 28 & 87 \\
\hline 2162.4 & rd vf ss w/wh bltch $50 \%$ opq (8-9) & 29.8 & 9.85 & 33 & 66 \\
\hline 2315.3 & 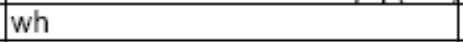 & 6.6 & 1.28 & 19 & 80 \\
\hline 2315.3 & rd & 6.7 & 1.19 & 18 & 80 \\
\hline 2385 & gry clayey opaques $(10)$ & 10.8 & 2.86 & 26 & 77.5 \\
\hline 3540.3 & dirty wh, salt/pepper look (spike) & 14.5 & 13.7 & 94 & 81 \\
\hline 4609.5 & rd w/gry stripes, heavy min (spike & 7.7 & 4.44 & 58 & 75 \\
\hline 770.7 & red shale chip & & & & 67 \\
\hline 1094.1 & gray mud laminae, & & & & 76 \\
\hline 3549.3 & dull gray red sandstone & & & & 83 \\
\hline 4610.3 & med gray laminated siltstone & & & & 75 \\
\hline 3536.3 & dull gray lam in sandstone & & & & 76 \\
\hline GRAND ISLAND & outcrop clayey crumbly & 18.6 & 15.6 & 84 & 81 \\
\hline CG509/l S3 & & Cs & 252 & & \\
\hline $\begin{array}{l}\text { CG509/LS3 } \\
\text { CG509/LS3 }\end{array}$ & & 6.6 & 35.3 & & \\
\hline CG509/LS3 & & 6.6 & 35.9 & & \\
\hline GRAND ISLAND R & & 19 & 15.3 & & \\
\hline $2315.3^{\prime}$ white $\mathrm{R}$ & & 6.6 & 1.26 & & \\
\hline & $\begin{array}{l}\text { Total-Partial correlation } \\
\text { Total-\%illite correlation } \\
\% \text { leachable vs } \% \text { illite correlation }\end{array}$ & $\begin{array}{l}0.784015024 \\
-0.447216406 \\
0.064906569\end{array}$ & & $\begin{array}{l}\text { average illite } \\
\text { max } \\
\text { min } \\
\text { count }\end{array}$ & $\begin{array}{r}79.13043478 \\
94 \\
63 \\
23\end{array}$ \\
\hline
\end{tabular}


Table 11 Analyses of Samples from Rice Lake Core.

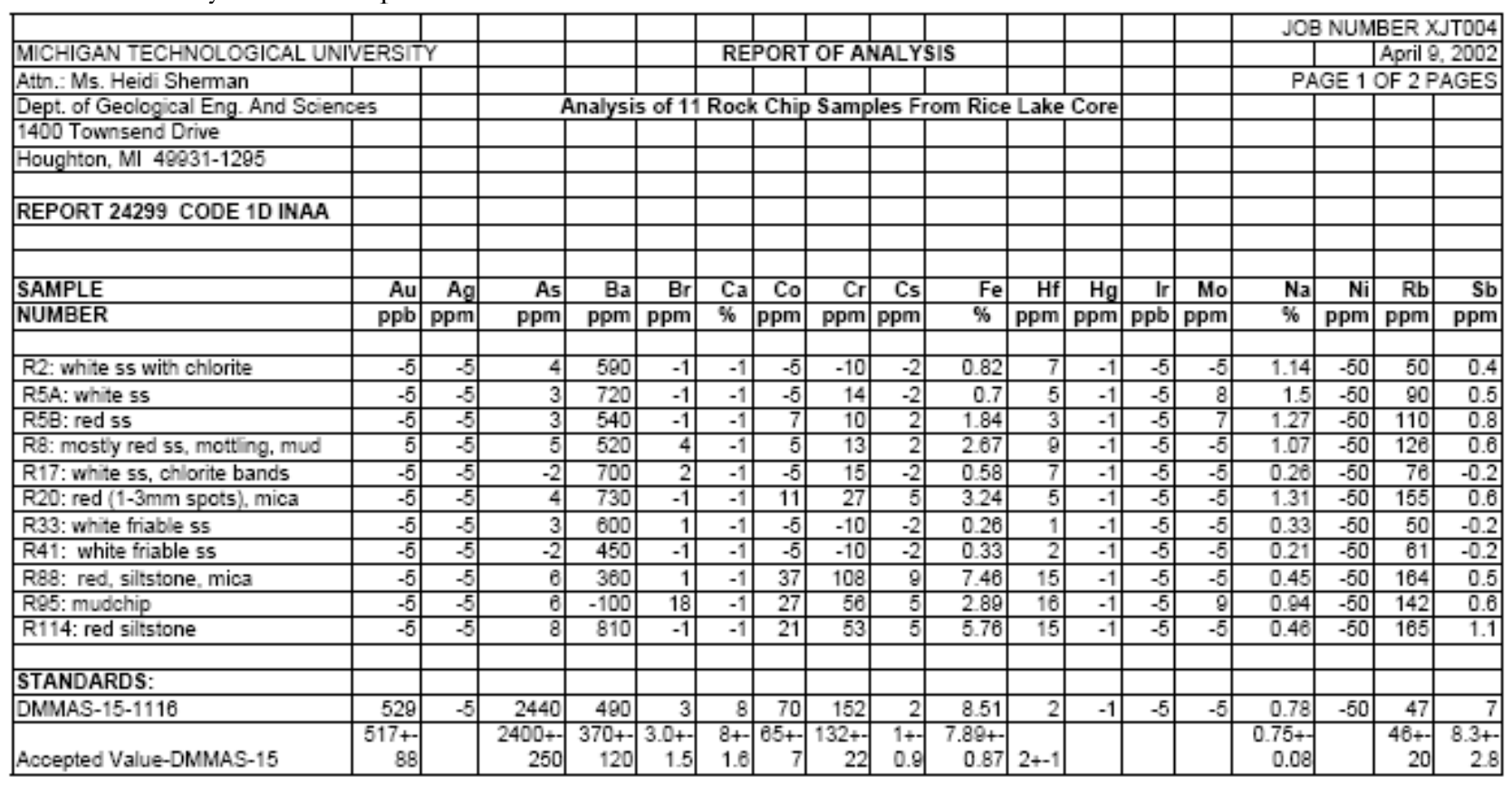

Continued 


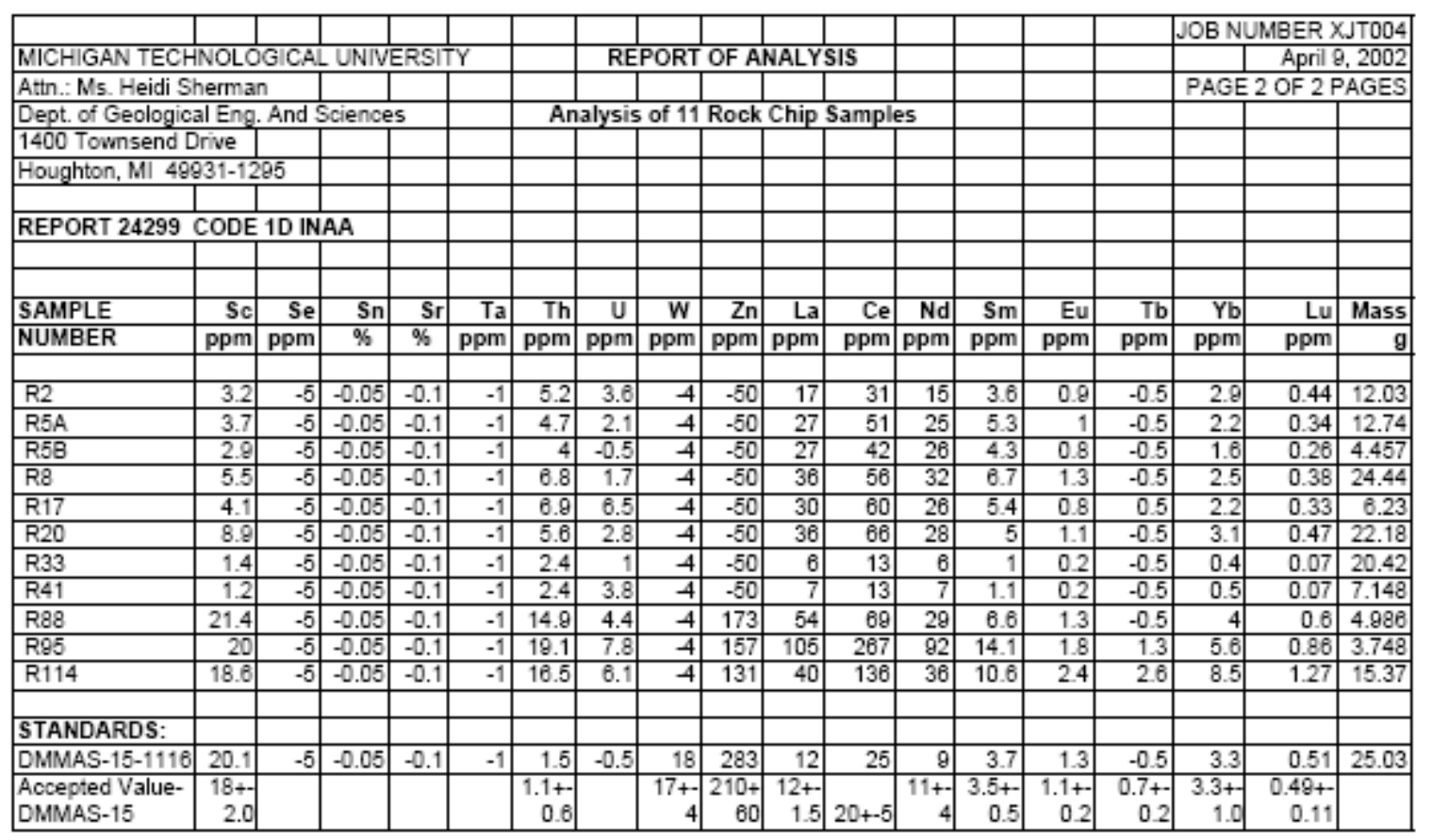




\section{REFERENCES}

Abdelouas, A., Lutze, W. and Nuttall. 1998. Chemical reactions of uranium in ground water at a mill tailings site. Journal of Contaminant Hydrology, Vol. 34, pp. 343-361.

Abdelouas, A. Young, L., Lutze, W. and Nuttall, H. E. 1998. Reduction of U(VI) to U(IV) by indigenous bacteria in contaminated ground water. Journal of Contaminant Hydrology, Vol. 35, pp. 217-233.

Abdul-Hadi, A., Alhassanieh, O. and Ghafar, M. 2001. Disequilibrium of uranium isotopes in some Syrian groundwater. Applied Radiation and Isotopes, 55, pp. 109-113.

Albertson, P. N. 2003. Naturally occurring radionuclides in Georgia water supplies: Implications for community water systems. Proceedings of the 2003 Georgia Water Resources Conference, University of Georgia.

Arendt, J. W., and Butz, T. R. 1980 a. Hydrogeochemical and stream sediment reconnaissance basic data for Iron River NTMS quadrangle, Michigan. NURE Report K/UR-137.

Arendt, J. W., and Butz, T. R. 1980 b. Hydrogeochemical and stream sediment reconnaissance basic data for Marquette NTMS quadrangle, Michigan. NURE Report K/UR-136.

Arnold, T., Zorn, T., Bernhard, G., Nitsche, H. 1998. Sorption of uranium (VI) onto phyllite. Chemical Geology, Vol. 151, pp. 129-141.

Asikainen, M. 1981. State of disequilibrium between 238-U, 234-U, 226-Ra and 222-Rn in groundwater from bedrock. Geochimica et Cosmochimica Acta, Vol. 45, pp. 201 206.

Ayotte, J. D., S. M. Flanagan, and D. L. Montgomery. 2001. Arsenic and radionuclides in bedrock groundwater, eastern New England. Abstracts with Programs - Geological Society of America, Vol.33, no. 1 p. 62.

Babcock, L. L 1975. Field trip 3: The Jacobsville Sandstone: evidence for a lower-middle Keweenaw Age. Twenty-First Annual Institute on Lake Superior Geology, Northern Michigan University, Marquette, MI. April 30 - May 4, pp. 87-123.

Bockgard, N., Rodhe, A. and Olsson, K. A. 2004. Accuracy of CFC groundwater dating in a crystalline bedrock aquifer: Data from a site in southern Sweden. Hydrogeology Journal, Vol. 12, pp. 171-183.

Belleveau, L. P. (1991). Fractures in the Jacobsville Sandstone and the Precambrian "W" rocks in the eastern Marquette County, Michigan. Masters Thesis, Western Michigan University, pp. 69.

Betcher, R. N., M. Gascoyne, and D. Brown. 1988. Uranium in groundwater of southeastern Manitoba, Canada. Canadian Journal of Earth Science, Vol. 25 pp. 2089-2103.

Bonotto, D. M. 2000. Applicability of the uranium-isotope model as a prospecting technique in Guarzy aquifer, South America. Ninth Annual Goldschmidt Conference, Journal of Conference Abstracts.

Bowers, M. C. 1989. Vertical petrologic changes of the Jacobsville Sandstone at Rice Lake Hole \#1. Masters Thesis, Michigan Technological University, pp. 176.

Brasser, T., Noseck, U., Schonwiese, D. 2002. Uranium migration in argillaceous sediments as analogue for transport processes in the far field of repositories (Heselbach Site, Germany). Merkel, B. J., Planer-Friedrich, B. and Wolkerdorfer, C. (eds). Proceedings of the International Conference Uranium Mining and Hydrogeology III 
and the International Mine Water Association Symposium Freiberg, Germany, 15-21 September, pp. 139-146.

Bristow, C. S. and Myers, K. J. 1989. Detailed sedimentology and gamma-ray log characteristics of a Namurian deltaic succession I: Sedimentology and facies analysis, II Gamma-ray logging. In Deltas: Sites and Traps for Fossil Fuels, Whateley, M. K. \& Pickering, K. T. (eds), Geological Society Special Publication No. 41, pp. 75-80, 81-88.

Buckley, D. K. and Oliver, D. 1990. Geophysical logging of water exploration boreholes in the Deccan Traps, Central India. In: Geological Applications of Wireline Logs Geological Society Special Publication No. 48, pp. 153-161.

Busenberg, E., and Plummer, L. N. 1992. Use of chlorofluorocarbons (CCl3F and CCl2F2) as hydrologic tracers and age-dating tools: The alluvium and terrace system of central Oklahoma. Water Resources Research, Vol. 28, No. 9, pp. 2257-2283.

Carr, M. 2004. Personal communication, July 13.

Chabaux, F., Riotte, J., Clauer, N. France-Lanord, C. 2000. U fluxes of the Himalayan Rivers: Implications for the U oceanic budget. Goldschimidt 2000. Journal of Conference Abstracts, Vol. 5, No. 2, p. 293.

Cuttell, J. C., Ivanovich, M., Tellam, J. H. and Lloyd, J. W. 1988. Uranium-series isotopes in the groundwater of the Permo-Triassic sandstone aquifer, Lower-Mersey Basin, U.K. Applied Geochemistry, Vol. 3, pp. 255-171.

Dabous A, A. and Osmond, J. K. 2001. Uranium isotopic study of artesian and pluvial contributions to the Nubian Aquifer, Western Desert, Egypt. J Hydrol. Vol 243, pp. 242-253.

Daniels, P. A. and Elmore, R. D. 1988. Overview - Upper Keweenawan Rift system, Michigan, in Upper Keweenawan Right-fill sequence, Mid-Continent Rift system, Michigan: Michigan Basin Geological Society Field Guide, Wollensak, M. (ed), pp. 150.

Davies, S. J. and Elliot, T. 1996. Spectral gamma ray characterization of high resolution sequence stratigraphy: examples from Upper Carboniferous fluvio-deltaic systems, County Clare, Ireland. In: High Resolution Sequence stratigraphy: Innovations and applications, Geological Society special Publication No. 104, pp. 25-35.

Dickas, A. B. and Mudrey, M. G. 1999. Terra-Patrick \#7-22 deep hydrocarbon test, Bayfield County, Wisconsin: investigations and final report. Wisconsin Geological and Natural History Survey Miscellaneous Paper 97-1, pp. 117.

Duff, M. C. and Amrhein, C. 1996. Uranium(VI) adsorption on Goethite and soil in carbonate solutions. Soil Sci. Soc. Am. J., Vol. 60, pp. 1393-1400.

Duff, M. C., Coughlin, J. U. and Hunter, D. B. 2002. Uranium co-precipitation with iron oxide minerals. Geochimica et Cosmochimica Acta, Vol. 66, No. 20, pp. 3533-3547.

Durrance, E. M. 1984. Uranium in the New Red Sandstone of south-east Devon. Proceedings of the Ussher Society, 6, pp. 108-115.

Ehrenberg, S. N. and Svana, T. A. 2001. Use of spectral gamma ray signature to interpret stratigraphic surfaces in carbonate strata; an example from the finnmark carbonate platform (Carboniferous-Permian), Barent Sea. Annual meeting expanded abstracts AAPG, Vol. 6, pp. 56-57.

EPA 2000. Technical fact sheet: final rule for (non -radon) radionuclides in drinking water. EPA 815-F-00-013. [cited May 19, 2004] Available from: www.epa.gov/safewater/rads/technicalfacts.html 
Fiedor, J. N., Bostick, W. D., Jarabek, R. J. and Farrell, J. 1998. Understanding the mechanism of uranium removal from groundwater by zero-valent iron using x-ray photoelectron spectroscopy. Environ. Sci. Technol., Vol. 32, pp.1466-1473.

Finch, W. I. and Davis, J. F. 1985. Geological environments of sandstone-type uranium deposits. Report of the Working Group on Uranium Geology organized by the International Atomic Energy Agency, Vienna. IAEA-TECDOC-328, pp. 408.

Frishman, D., Pitkin, J. A., Duval, J. S., Brock, M. R., Cannon, W. F., Ojakangas, R. W., Peterson, W. L., Kalliokoski, J. and Wahl, R. R. 1982. National Uranium Resource Evaluation: Iron River Quadrangle, Michigan and Wisconsin. USGS, Golden, Colorado, prepared for the US DOE Grand Junction Area Office. DE82 021094, PGJ/F-120-82.

Gearhart Industries, Inc. 1986. Interpretation of the Spectral Gamma Ray, in house manual Fort Worth Texas, 59 pp.

Gascoyne, M. 1981. A simple method of uranium extraction from carbonate groundwater and its application to 234-U/238-U disequilibrium studies. J. Geochem. Explor., Vol. 14, pp. 199-207.

Gascoyne, M. 1992. Geochemistry of the actinides and their daughters. In: Uranium-series disequilibrium. Ivanovich, M., Harmon, R. S. (eds) Clarendon Press, Oxford, pp. 3461.

Gascoyne, M., Miller, N. H. and Neymark, L. A. 2002. Uranium-series disequilibrium in tuffs from Yucca Mountain, Nevada, as evidence of pore-fluid flow over the last million years. Applied Geochemistry, Vol. 17, pp. 781-792.

Hakam, O. K., Choukri, A., Reyss, J. L. and Lfrede, M. 2001. Determination and comparison of uranium and radium isotopes activities and activity ratios in samples from some natural water sources in Morocco. Journal of Environmental Radioactivity, Vol. 57, pp. 175-189.

Hakonson-Hayes, A. C., Fresquez, P. R. and Whicker, F. W. 2002. Assessing potential risks from exposure to natural uranium in well water. Journal of Environmental Radioactivity, Vol. 59, pp. 29-40.

Hamblin, W. K., 1958. The Cambrian sandstone of Northern Michigan. USGS publication 51. pp.146.

Ingebritsen, S. E. and W. E. Sanford. 1998. Groundwater in Geologic Processes, Cambridge University Press, Cambridge, pp. 142-148.

Hedgeman, C. A. 1992. Provenance and tectonic setting of the Jacobsville Sandstone, from Ironwood to Keweenaw Bay, Michigan. Masters Thesis, University of Cincinnati, pp. 141.

Hollocher, K., and A. Yuskaitis. 1993. Chemical composition of surface and high-uranium well water, Lake Sunapee area, New Hampshire. Northeastern Geology, v. 15 no. 2, pp. 159-169.

Hoffman, M. A. 1987. The Southern Complex: geology, geochemistry, mineralogy and mineral chemistry of selected uranium- and thorium-rich granites. PhD Dissertation, Michigan Technological University, pp. 382.

Ingebritsen, S. E. and W. E. Sanford. 1998. Groundwater in Geologic Processes, Cambridge University Press, Cambridge, pp. 142-148.

Ivanovich, M. and Alexander, J. 1987. Application of uranium-series disequilibrium to studies of groundwater mixing in the Harwell region, U.K. Chemical Geology (Isotope Geoscience Section), 66, pp. 279-291. 
Ivanovich, M., K. Frohlich, and M. J. Hendry. 1991. Uranium-series radionuclides in fluids and solids, Milk River aquifer, Alberta, Canada. Applied Geochemistry, Vol. 6, pp. 405-418.

Israelson, C., Bjorchk, S., Hawkesworth, C. J. and Possnert, G. 1997. Direct U-Th dating of organic- and carbonate-rich lake sediments from southern Scandinavia. Earth and Planetary Science Letters, 153, pp. 251-263.

Johnson, C. A. 1977. Uranium and thorium occurrences in Precambrium rocks, Upper Peninsula of Michigan. Masters Thesis, Michigan Technological University, pp. 217.

Kalliokoski, J. 1976. Uranium and thorium occurrences in Precambrium rocks, Upper Peninsula of Michigan and Northern Wisconsin; with thoughs on other possible settings. Report to US Energy Research and Development Administration, pp. 294.

Kalliokoski, J. 1982. Jacobsville Sandstone, in Geology and tectonics of the Lake Superior Basin Wolds, R. J., and Hinze, W. J., (eds), Geological Society of America Memoir 156.

Kim, J., and Becker, L. 2001. Geologic context of elevated radionuclide occurrences in NW Vermont. Abstracts with Programs - Geological Society of America 33, no. 1, p. 60.

Kim, Y. 1999. The concentrations and distributions of $U$ and Th in Paleozoic aquifers surrounding the Llano Uplift area, central Texas, USA: application to the sources of $\mathrm{Ra}$ and Rn in groundwater. Geosciences Journal, Vol. 3, No. 4, pp. 201-211.

Kinze, M. 2002. Dose limits and maximum concentration limits (MCLs) for radionuclides implication on remediation of uranium mining and milling facilities in Saxony, Germany. Proc. of the International Conference Uranium Mining and Hydrogeology III and the International Mine Water Association Symposium Freiberg, Germany, 15-21 September 2002, pp. 1-6.

Kramer, R. 2004. Personal communitcation, July 14.

Kronfeld, J., Vogel, J. C., Talma, A. S. 1994. A new explanation for extreme 234-U/238-U disequilibria in a dolomitic aquifer. Earth and Planetary Science Letters, 123, pp. 81 93.

Kyser, K. and Hiatt, E. 2003. Fluids in sedimentary basins: an introduction. Journal of Geochemical Exploration, Vol. 80, pp. 139-149.

Lambert, I., McKay, A. and Miezitis, Y. 2001. Australia's uranium resources and production in a world context, Bureau of Resources Sciences, Canberra, ANA Conference October.

Langmuir, D. 1997. Aqueous Environmental Geochemistry. Prentice-Hall, New Jersey, pp. 486-547.

Latham, A. G. and Schwarcz, H. P. 1987. On the possibility of determining rates of removal of uranium from crystalline igneous rocks using U-series disequilibria - 2:

applicability of U-leach model to mineral separates. Applied Geochemistry, Vol. 2, pp. 67-71.

Lee, L. M. and Herbert, B. E. 2001. A GIS survey of arsenic and other trace metals in groundwater resources of Texas. Geological Society of America, 2001 annual meeting, Abstracts with Programs - GSA 33, no. 5, p. 53.

Lindsay, D. W. 1986. The provenance of the Jacobsville Formation of the Upper Peninsula of Michigan through a petrographic study. Masters Thesis, Western Michigan University, pp. 111.

Luo, S., Ju, T.,Roback, R., Murrel, M., McLing, T. L. 2000. In-situ radionuclide transport and preferential groundwater flows at INEEL (Idaho): Decay-series disequilibrium studies. Geochimica et Cosmochimica Acta, Bol. 64, Nol. 5, pp. 967-881. 
Mankowski, L. 2004. Personal communication, June 29.

Merkel, B. J., Planer-Fiedrich, B., and Wolkersdorfer, C. 2002. Preface. Proc. of the International Conference Uranium Mining and Hydrogeology III and the International Mine Water Association Symposium Freiberg, Germany, 15-21 September 2002, p. xvii.

Missana, T., Garcia-Gutierrez, M. and Fernndez, V. 2003. Uranium (VI) sorption on colloidal magnetite under anoxic environment: Experimental study and surface complexation modeling. Geochimica et Cosmochimica Acta, Vol. 67, No. 14, pp. 25433-2550.

Nikie, Z., Kovacevic, J., Radosevic, B. 2002. Uranium content in groundwater in Stara Planina Triassic sediments. Merkel, B. J., Planer-Friedrich, B. and Wolkerdorfer, C. (eds). Proceedings of the International Conference Uranium Mining and Hydrogeology III and the International Mine Water Association Symposium Freiberg, Germany, 15-21 September, pp. 99-106.

North, C. P., and Boering, M. 1999.Spectral gamma-ray logging for facies discrimination in mixed fluvial-eolian successions: a cautionary tale, AAPG Bulletin, Vol. 83, No. 1, pp. 155-169.

Norvell, J. L. 1995. Distribution of, sources of, and processes mobilizing arsenic, chromium, selemium, and uranium in the central Oklahoma aquifer. Masters Thesis, Colorado School of Mines, Golden, CO, pp. 169.

Noseck, U., Brasser, T., Laciok, A., Hercik, M, and Woller, F. 2002. Uranium migration in argillaceous sediments as analogue for transport processes in the far field of repositories (Ruprechtov site, Czech Republic). In Uranium in the aquatic environment. Merkel, B. J., Planer-Friedrich, B. and Wolkerdorfer, C. (eds). Preceedings of the International Conference Uranium Mining and Hydrogeology III and the International Mine Water Association Symposium Freiberg, Germany, 15-21 September, pp. 207-215.

Ojakangas, R. W. and Dickas, A. B. 2001. The 1.1-Ga Midcontinent Rift System, central North America: sedimentology of two deep boreholes, Lake Superior region. Sedimentary Geology, Vol. 147, pp. 13-36.

Ojakangas, R. W., Morey, G. B. and Green, J. C. 2001. The Mesoproterozoic Midcontinental Rift System, Lake Superior Region, USA. Sedimentary Geology, Vol. 141-142, pp. 421-442.

Osmond, J. K. and Cowart, J. B. 1992. Ground water. In: Uranium-series disequilibrium. Ivanovich M, Harmon RS (eds), Clarendon Press, Oxford, England, pp.290-334.

Paces, J. B., Ludwig, K. R., Peterman, Z. E. and Neymark, L. A. 2002. U-234/U-238 evidence for local recharge and patterns of ground-water flow in the vicinity of Yucca Mountain, Nevada, USA. Applied Geochemistry Vol. 17, No. 6, pp. 751-779.

Parker, R. L, and Herbert, B, E. 2000. Using GIS and U mining history to identify trace element "hotspots" within a South Texas watershed. Geologyical Society of America, 2000 annual meeting Abstracts with Programs - GSA 32, no. 7, pp. 125.

Porcelli, D. and Swartzenski, P.W. 2003. The behavior of U- and Th-series nuclides in groundwater. In: Uranium-series Geochemistry. Bourdon, B., Henderson, G. M., Lundstrom, C. C., and Turner, S. P. (eds), Mineralogical Society of America, pp. $317-$ 361.

Reynolds, B. C., Wasserburg, G. J. and Baskaran, M. 2003. The transport of U-and Thseries nuclides in sandy confined aquifers. Geochimica et Cosmochimica Acta, Vol. 67, No. 11, pp. 1955-1972. 
Roback, R. C., Johnson, T. M., McLing, T. L., Murrell, M. T., Luo, S., Ku, T. 2001. Uranium isotopic evidence for ground water chemical evolution and flow patterns in the eastern Snake River Plain aquifer, Idaho. GSA Bulletin, Vol. 113, No. 9, pp. 1131141.

Sato, T., Murakami, T., Yanase, N., Isobe, H., Payne, T. E., and Airey, P. L. 1997. Iron nodules scavenging uranium from groundwater. Environ. Sci. Technol. Vol. 31, pp. 2854-2858.

Saum, N. M. and Link, J. M. 1969. Exploration for uranium. Mineral Industries Bulletin, Colorado School of Mines Research Institute, Vol. 12, No. 4, pp. 18.

Schlumberger. 2000. Log Interpretation Charts. Sugar Land, Texas, pp. 4-30.

Seiler, R. L. 2004. Temporal Changes in Water Quality at a Childhood Leukemia Cluster. Ground Water. Vol. 42, No. 3, pp. 446-455.

Sinha, D. K., P. K. Shrivastava, S. K. Hansoti, and P. K. Sharma. 1997. Uranium and radon concentration in ground water of Deccan Trap country and environmental hazard in Keolari-Nainpur area, Seoni-Mandla District, Madhya Pradesh. Special Publication Series - Geological Survey of India Vol. 48, no. 2 pp. 115 -121.

Smith, S.M., 2001. National Geochemical Database: Reformatted data from the National Uranium Resource Evaluation (NURE) Hydrogeochemical and Stream Sediment Reconnaissance (HSSR) Program, Version 1.30: U.S. Geological Survey Open-File Report 97-492, WWW release only, URL:

http://greenwood.cr.us.g.gov/pub/open-file-reports/ofr-970492/index.html, last accessed Nov. 2002.

Spirakis, C. S. 1996. The roles of organic matter in the formation of uranium deposits in sedimentary rocks. Ore Geology Reviews, Vol. 11, pp. 53-69.

Szabo, Z., and O. S. Zapecza. 1991. Geologic and geochemical factors controlling uranium, radium-226, and radon-222 in groundwater, Newark Basin, New Jersey. In Field Studies of Radon in Rocks, Soils and Water. USGS Bulletin: 243 pp. 265.

Szabo, Z., Taylor, T. A., Payne, D. R., and Ivahnenko, T. 1997. Relation of hydrogeologic characteristics to distribution of radioactivity in groundwater, Newark Basin, New Jersey. USGS Water-Resources Investigations Report 95-4136. pp. 134.

Temple, T. 2002. personal communication via email, June 14.

Tricca, A., Wasserburg, G. J. 2000. Factors controlling the ground watergroundwater transport of U, Th, Ra, and Rn. Proc Indian Natl Acad Sci 109, pp. 95-108.

Tricca, A. Wasserburg, G. J., Porcelli, D. and Baskaran, M. 2001. The transport of U-and Th-series nuclides in a sandy unconfined aquifer. Geochimica et Cosmochimica Acta, Vol. 65, No. 8, pp. 1187-1210.

USGS. 1998. PHREEQCI - A graphical user interface for the geochemical computer program PHREEQC [cited July 7, 2004]. Available from: http://wwwbrr.cr.usgs.gov/projects/GWC_coupled/phreeqci/.

USGS. 2003. Collections and preservation of water samples for chlorofluorocarbon analysis in glass bottles with foil-lined caps [cited May 19, 2004]. 5 p. Available from: water.usgs.gov/lab/cfc/sampling/newmethod.htm.

Verstraeten, I. M., Karl, B. J., Kraemer, T. F., and Cannia, J. C. 2002. Use of environmental tracers and isotopes to evaluate sources of water, nitrate, and uranium in an irrigated alluvial valley, Nebraska. U.S.G.S. Fact Sheet, FS 01000-01.

Vickers, R. C. 1956. Origin and occurrence of uranium in northern Michigan. USGS Open File Report, pp. 76. 
Western Upper Peninsula Health Department. 2001. www.westernuphealth.org/Archives/Articles/articles.html, last accessed June, 2004.

Wong, C. T., H. S. Okamoto, A. M. Milea, K. K. Perera, and F. J. Baumann. 1999. Isotopic uranium activity ratios in California ground water. Journal AWWA, Vol. 91, issue 4, pp. 171-185.

Young, C. T and Repasky, T. R. (1986). A magnetotelluric transect of the Jacobsville Sandstone in northern Michigan. Geological Society of America Bulletin, Vol. 97, pp. 711-716.

Zouridakis, N., Ochsenkuhn, K. M., Savidou, A. 2002. Determination of uranium and radon in potable water samples. Journal of Environmental Radioactivity, Vol. 61, pp. 225-232. 